\title{
Cink-peroxid és cink-oxid tartalmú hibrid rétegek optikai, szorpciós és szenzorikus tulajdonságai
}

\author{
$\mathrm{Ph}$. D. értekezés \\ Sebők Dániel \\ okleveles fizikus \\ Témavezető: \\ Dr. Dékány Imre \\ egyetemi tanár, az MTA rendes tagja
}

Kémia Doktori Iskola

Fizikai Kémiai és Anyagtudományi Tanszék

SZTE TTIK

2012

Szeged 


\section{Tartalomjegyzék}

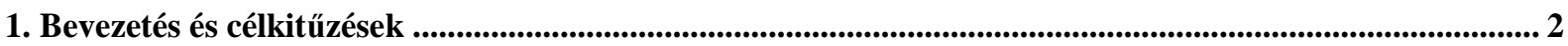

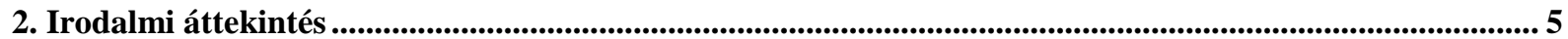

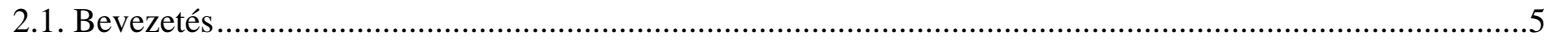

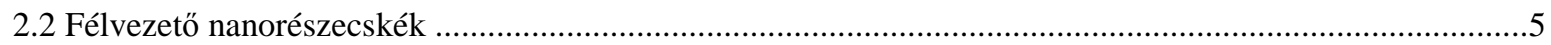

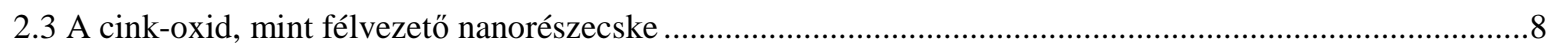

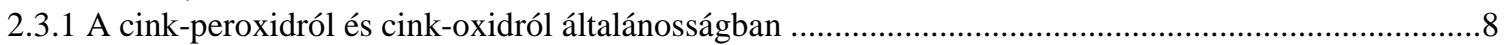

2.3.2 Nanoszerkezetủ cink-peroxid és cink-oxid elóállítása ..........................................................................

2.4. Önrendeződő vékonyrétegek elöállítása és tulajdonságai.......................................................................11

2.5. Vékonyrétegek optikai tulajdonságainak meghatározására szolgáló módszerek........................................13

3. Anyagok és módszerek....................................................................................................................................... 15

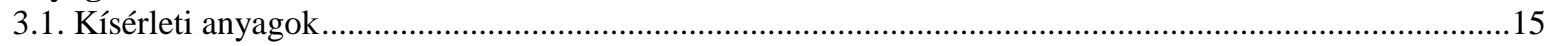

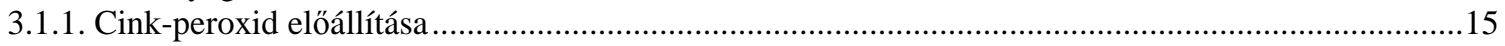

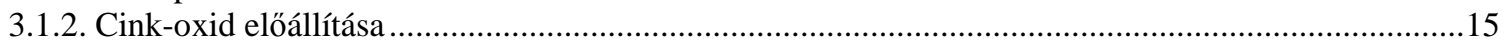

3.1.3. Kötőanyagként használt szervetlen (részecskék) és szerves (polimer) kolloidok .................................15

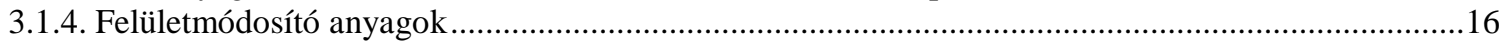

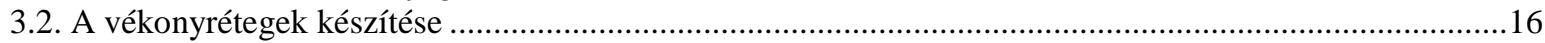

3.2.1. Cink-peroxid/PSS és cink-peroxid/Na-hektorit vékonyrétegek készítése.............................................16

3.2.2. Cink-peroxid/térhálós polimer vékonyrétegek készítése fotopolimerizációval ..................................17

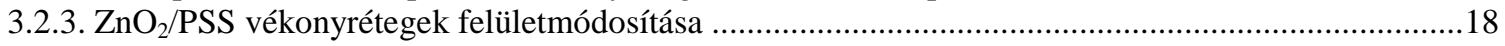

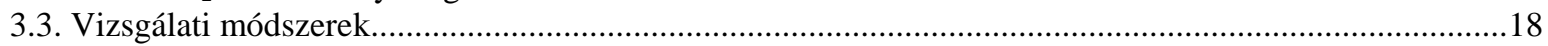

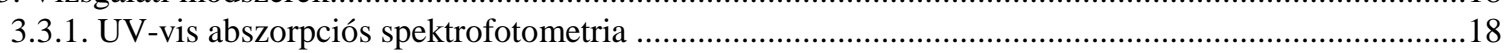

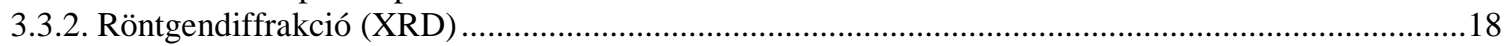

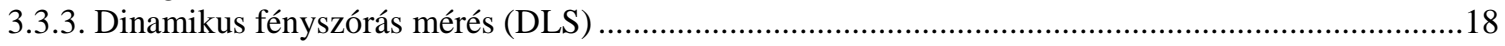

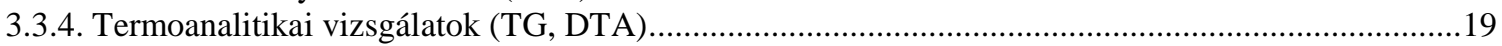

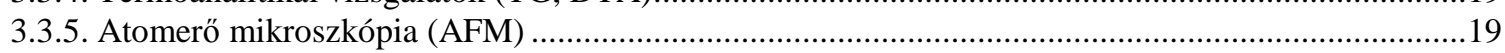

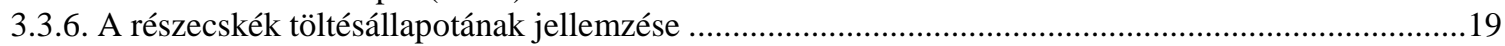

3.3.7. Transzmissziós elektronmikroszkópia (TEM) mérések …………………………………………....20

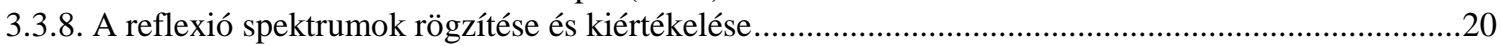

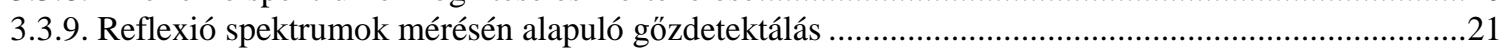

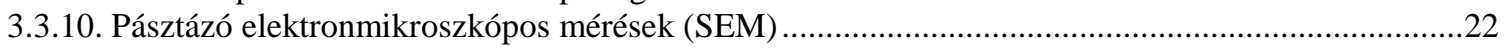

3.3.11. Kvarc kristály mikromérleggel végzett mérések (QCM) ............................................................22

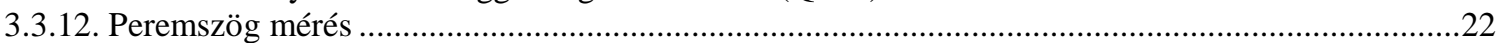

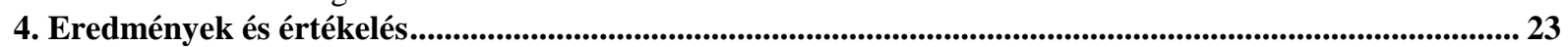

4.1. Cink-peroxid nanorészecskék előálítása és vizsgálata.....................................................................23

4.2. Pórusos önrendeződő vékonyrétegek optikai tulajdonságainak meghatározására szolgáló módszer

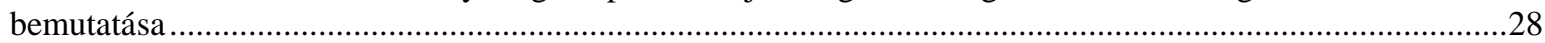

4.3. Cink-peroxid és cink-oxid tartalmú hibrid vékonyrétegek elöállítása és vizsgálata....................................33

4.3.1. Szilícium hordozóra épített $\mathrm{ZnO}_{2} / \mathrm{PSS}$ és $\mathrm{ZnO}_{2} / \mathrm{Na}$-hektorit filmek (kvalitatív) vizsgálata alapjelenségek bemutatása .................................................................................................................. 33

4.3.2. Üveg hordozóra épített $\mathrm{ZnO}_{2}$ /(PSS ill. Na-hektorit) és $\mathrm{ZnO} / \mathrm{Na}$-hektorit filmek vizsgálata .................34

4.3.3. $\mathrm{ZnO}_{2} /$ térhálós polimer hibrid vékonyrétegek üveg és arany bevonatú kvarckristály hordozón............41

4.4. Pórusos önrendeződő vékonyrétegek törésmutató változásának mérésén alapuló gőzszenzor bemutatása51

4.4.1. Általános müködési alapelvek bemutatása ................................................................................52

4.4.2. A felületmódosítások előminősítése QCM -mel és peremszög méréssel............................................55

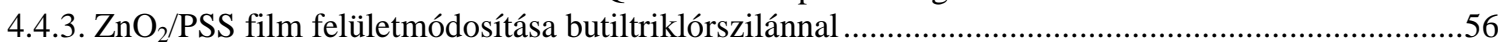

4.4.4. $\mathrm{ZnO}_{2} / \mathrm{PSS}$ film felületmódosítása oktántiollal borított nanoarany részecskékkel...............................63

4.4.5. A törésmutató változás kalibrációja kvarckristály mikromérleggel.........................................................68

4.4.6. A törésmutató változás és adszorptívum tömegtörtje közti összefüggés ..............................................74

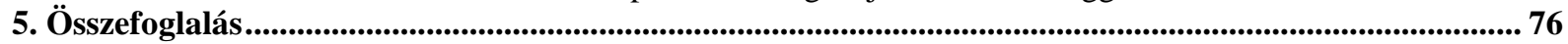

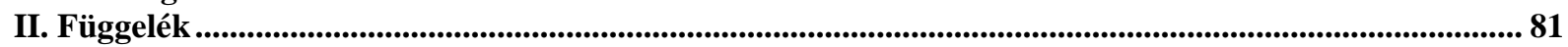

1. számú függelék - Az áramlásos mérörendszer müködésének bemutatása ....................................................81

2. számú függelék - A butiltriklórszilánnal módosított $\mathrm{ZnO}_{2} / \mathrm{PSS}$ hibrid vékonyrétegen végzett mérési

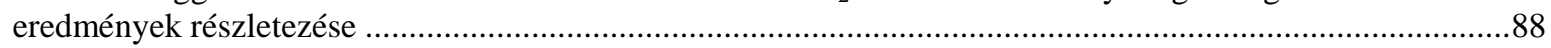

3. számú függelék - Az oktántiollal borított arany nanorészecskékkel (OT-AuNR) módosított $\mathrm{ZnO}_{2} / \mathrm{PSS}$

hibrid vékonyrétegen végzett mérési eredmények részletezése....................................................................101

III. Summary ............................................................................................................................................................ 104

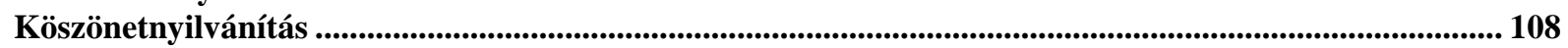

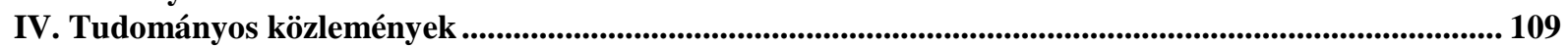

V. Irodalomjegyzék ................................................................................................................................................ 112 


\section{Bevezetés és célkitűzések}

„Amiröl beszélni akarok, az a dolgok rendkivül kis skálán történö ellenörzésének és befolyásolásának problematikája. Amint ezt megemlítem, az emberek rögtön a miniatürizálásról beszélnek, s arról, hogy ez mennyit fejlödött napjainkig. Elektromos motorokról beszélnek, amik akkorák, mint az ujjunk hegyén a köröm. És kapható olyan eszköz - mondják -, amivel a „Miatyánk” felírható egy gombostü fejére. De ez semmi; ez a legkezdetlegesebb, legnehézkesebb lépés abba az irányba, amelyröl beszélni szeretnék. Megdöbbentôen kis világ lapul még ez alatt is.

2000-ben, ha visszatekintenek a mi korunkra, azon fognak csodálkozni, hogy miért nem fordult elö 1960-ig, hogy valaki komolyan elmozdult volna ebbe az irányba. Miért ne tudnánk felírni a Brit Enciklopédia (Encyclopaedia Brittanica) mind a 24 kötetét egy gombostü fejére?".

(Richard P. Feynman [1])

Az idézet Richard P. Feynman „There's Plenty of Room at the Bottom” c. előadásából származik, melyet 1959. december 29-én tartott a Kaliforniai Technológiai Intézetben (Caltech). Ekkor a „chip” fogalma még ismeretlen volt, s a tranzisztor is alig 10 éve lett szabadalmaztatva. Ám Feynman megdöbbentő állításai és ,jóslatai” is csak egy közbülső állomást jelentenek a nanoméretekkel foglalkozó tudományok történetében. Úttörőnek számít Wolfgang Ostwald „Az elhanyagolt dimenziók világa” c. munkája, melynek első kiadása 1914-re datálódik, de ő is gyakran hivatkozik a fél évszázaddal korábban tevékenykedő skót kémikusra, Thomas Graham-re (1805-1869), akit gyakran emlegetnek a „kolloidkémia atyjá’-nak. Honfitársaink közül Ostwald kor- és munkatársaként úttörő jelentőségü Buzágh Aladár munkássága, s a teljesség igénye nélkül fontos megemlíteni még Zsigmondy Richárdot, az ultramikroszkóp (1903) megalkotóját is, aki elsőként tette láthatóvá a szóban forgó különös objektumokat, amiért Nobel-díjjal jutalmazták.

Felmerülhet a kérdés, miért e hiányos felsorolás a kolloidkémia $\mathrm{s}$ a nanotudományok úttörőiről? A válasz egyszerủ: a nanotechnológia robbanásszerủ fejlődésen megy keresztül, hetek-hónapok alatt termel annyi új eredményt, mint korábban évtizedek alatt. Közel másfél évszázadon át parlagon hevert korunk egyik legígéretesebb tudományága, miközben néhány évtizedenként fel-felbukkant egy-egy kiemelkedő tudós, ám a történelmi viszontagságok és a technológia hiányosságai miatt több-kevesebb időre feledésbe merültek nagyszerü és korszakalkotó eredményei. 
A nanotechnológia célkitüzéseinek megvalósításához a fizika és kémia határmezsgyéjén vezet az út. Napjainkra a biológia és a biotechnológia is szerves alkotójává és felhasználójává vált a kutatási eredményeknek. A vizsgálatok főként nanorészecskék, nanoszerkezetủ anyagok előállítására irányulnak, illetve ezen anyagok felhasználhatóságára valamely tudományos célú problémafelvetés megoldására. Mindennapi életünkben is egyre többször találkozunk újabb és újabb vívmányaival (nanoelektronika, szenzorok, antibakteriális hatás, fotokatalízis stb.).

A nanotechnológia és a biotechnológia (s a kettő együtt alkalmazása) minden bizonnyal a XXI. század tudományos robbanásának okozójává fog válni. Szabályozott méretủ és alakú, nagy fajlagos felületü nanorészecskék ill. nanoszerkezetü anyagok előállítása főként kolloidkémiai módszereket igényel, de különleges elektromos és optikai tulajdonságaik is ezen ismeretekkel magyarázhatók. Ezek közül is kiemelkedő fontosságúak a félvezetők ill. a félvezető nanorészecskék. Az utóbbi évtizedek elektronikai fejlődését a félvezető ipar megjelenése és exponenciális fejlődése váltotta ki, melynek fő irányvonala a miniatürizálás. A fejlődést korlátozhatná az a tény, hogy a méretek csökkentése nem folytatható minden határon túl (sem mérnöki, sem kvantummechanikai okokból), ugyanakkor még számos lehetőséget rejt a nano-mérettartomány különleges tulajdonságainak széles tárháza. A méret, alak, törésmutató, pórusosság, felületmódosítás stb. szerint szabályozható tulajdonságú részecskék szintetizálhatók, majd ezekből a célnak megfelelő, praktikus eszközök (pl. szenzorok, bevonatok) készíthetők és anyagok (pl. gyógyszerek, kompozitok) állíthatók elő. Bátran kijelenthetjük tehát, hogy közel másfél évszázad várakozás után a kolloidkémia ill. a nanotudományok forradalmasították és napról-napra bővítik a fizikai-kémia, az elektronika és az orvostudományok vívmányait.

Kutatásaim célja volt cink-peroxid nanorészecskék vizes diszperzióban történő szintézise. Vizsgáltam az előállított részecskék optikai és szerkezeti tulajdonságait, meghatároztam méretüket, tanulmányoztam termikus bomlásukat, valamint felületi töltésállapotukat.

A pozitív felületi töltésü $\mathrm{ZnO}_{2}$ részecskékből és a negatív felületi töltésü kötőanyagokból (PSS, poli(sztirolszulfonát); PAAm, poli(akrilamid) és PNIPAAm, poli(N-izopropilakrilamid), mint makromolekulák és Na-hektorit, mint rétegszilikát) ún. pórusos hibrid vékonyrétegeket állítottam elő bemerítéses (Layer-by-Layer, LbL) önrendeződő eljárással szilárd hordozó felületén. A lineáris polimer (PSS) tartalmú hibrideket hagyományos bemerítéses technikával készítettem, míg a térhálós polimer (PAAm, PNIPAAm) tartalmúak elkészítésénél az LbL technikát ötvöztem fotopolimerizációval, így a térháló „in-situ” a 
szilárd hordozó felületén jött létre. $\mathrm{A} \mathrm{ZnO}_{2} / \mathrm{Na}$-hektorit filmek $400{ }^{\circ} \mathrm{C}$ fok hőmérsékleten történő kezelésével nyertem $\mathrm{ZnO}$ tartalmú rétegeket, a cink-peroxid termikus bomlása eredményeképpen.

Vizsgáltam a filmek felépülését UV-látható abszorpciós ill. reflexiós spektrofotometriával és kvarckristály mikromérleg segítségével. A szerkezeti tulajdonságokat röntgen diffrakcióval, a morfológiát pedig atomerő mikroszkóppal és pásztázó elektronmikroszkóppal vizsgáltam.

Célul tüztem ki az elkészített hibrid vékonyrétegek optikai tulajdonságainak mérésére és jellemzésére szolgáló módszerek kidolgozását, első sorban a rétegvastagságot és a törésmutatót illetően. Ez utóbbi fontossága abban rejlik, hogy gázok, gőzök jelenlétében a filmek reflexió spektruma a vörös színtartomány irányába tolódik el, a törésmutató növekedése miatt. Ezért további célom volt a vékonyrétegek szenzorként való alkalmazhatóságát vizsgálni saját fejlesztésű áramlásos rendszerben, különböző polaritású gőzök jelenlétében. A hibrid filmeket speciális kötőanyaggal (PAAm, PNIPAAm) ill. felületmódosítással (butiltriklórszilán, oktántiol) szelektívvé, azaz egyes anyagokra specifikusan érzékennyé tettem. 


\section{Irodalmi áttekintés}

“ Könyvek révén sokan lesznek tudóssá az iskolán kívül is, könyvek nélkül viszont senki nem lesz tudós, még az iskolában sem!”

(Jan Amos Komensky)

\subsection{Bevezetés}

A nanorészecskék (a kolloid mérettartomány 1-100 nm-es sávjában elhelyezkedő méretü részecskék) főként a félvezető nanoszerkezetű anyagok előállítása és tulajdonságaik vizsgálata igen nagy jelentőségre tett szert napjainkban, mivel a technológia méretcsökkentő tendenciái ebben a mérettartományban korlátozódni látszanak, mellesleg a nanoméretek elérésekor különleges tulajdonságok jelennek meg, melyek révén a nanoszerkezetü anyagok igen jól hasznosíthatók korunk legaktuálisabb problémáinak és igényeinek kezelésekor, azaz a csúcstechnológiában, orvostudományban, környezetvédelemben.

Kolloidkémiai jelenségekkel magyarázhatóak a tömbfázistól eltérő tulajdonságok: a méret fokozatos csökkentésével megváltoznak az elektromos, katalitikus, optikai tulajdonságok (méret kvantálás). A méret csökkenésével párhuzamosan és rohamosan nő a fajlagos felület, ami miatt jelentős katalitikus aktivitás figyelhető meg. Jelentős változások tapasztalhatók a fizikai tulajdonságokban: megváltozik a sürüség, olvadáspont, elektromos vezetés.

\subsection{Félvezető nanorészecskék}

A félvezető tulajdonságú fém-oxidok széleskörü felhasználási területtel bírnak, ugyanis szerepük igen fontos a mikroelektronikában, számítógépek és egyéb mikroprocesszort tartalmazó eszközök gyártásában. Ezen a területen fontos szerepet kaphatnak a jövőben, a folyamatos miniatürizálási versenyben egyre gyakrabban alkalmazzák őket, mivel segítségükkel a méretek lecsökkenthetők, míg a tárolókapacitások sokszorosukra növelhetők. Ezen felül a környezetvédelemben is alkalmazhatók, mint a szennyező anyagokat érzékelő szenzorok alapanyagai illetve azok lebontására alkalmas katalizátorok. A félvezető fém-oxid nanorészecskék alkalmazhatók tehát a fotokatalízisben, elektonikai, optikai berendezésekben és szenzorokban. Látjuk, hogy kitüntetett szerepet töltenek be a nanovilágban a félvezető részecskék, de tulajdonképpen mit is értünk félvezető tulajdonságú anyag alatt?

A félvezetők olyan anyagok (oxidok, szulfidok, szennyezett félfémek), amelyek átmenetet képeznek a vezetők és szigetelők között (fajlagos vezetésük: $10^{-9}-10^{3} 1 / \Omega \mathrm{cm}$ ), vezetőképességük függ a hőmérséklettől, a nyomástól, a megvilágítástól illetve az alkalmazott külső tértől, és vezetés csak gerjesztett állapotban jelentkezik. A félvezetők tulajdonságai jól 
értelmezhetők a sávelmélet segítségével: az elektronszerkezetben különböző sávok figyelhetők meg, az úgynevezett megengedett sáv, melynek része a vegyérték sáv és vezetési sáv illetve ezek között helyezkedik el a tiltott sáv. Ahhoz, hogy áramvezetés jöjjön létre, elektronnak kell átjutnia a vegyértéksávból a vezetési sávba, ami csak akkor jöhet létre, ha az elektron rendelkezik azzal az energiával, ami ehhez az átugráshoz szükséges. Ez külső tér segítségével, főként ultraibolya fénnyel történő megvilágítással valósítható meg. Amikor a félvezető részecskéit fénybesugárzás éri, átugrik egy elektron a vezetési sávba, miközben a vegyértéksávban egy pozitív töltésű lyuk marad vissza. Így megvalósul a töltés szeparáció jelensége [2].

Minden félvezetőre jellemző, hogy egy bizonyos $\lambda_{\mathrm{g}}$ hullámhossz alatt elnyeli a fényt. Ez a $\lambda_{\mathrm{g}}$ hullámhossz az abszorpciós küszöbérték, mely fordítottan arányos a gerjesztési küszöbenergiával $\left(\mathrm{E}_{\mathrm{g}}\right)$ a következő összefüggés alapján [3]:

$$
\lambda_{g}(n m)=\frac{1240}{E_{g}(e V)}
$$

Beszélhetünk n- és p-típusú félvezetőkről. Az előbbinél az elektronok, míg utóbbinál a pozitív töltésủ lyukak biztosítják az áramvezetést. A szétválás után kifelé semleges elektronlyuk párt alkotnak, mely állapotot exciton állapotnak nevezünk. A félvezetők úgynevezett csapdahelyeket is tartalmazhatnak az elektronok és lyukak számára, ezek lehetnek különböző hibahelyek vagy szennyeződések, melyek legtöbbször a részecskék felületén helyezkednek el. A töltéshordozók rekombinációja történhet az exciton állapotból, ill. a hibahelyekről sugárzással járó vagy sugárzásmentes relaxációval.

Ezen tények viszonylag régóta ismeretesek a félvezetőkkel kapcsolatban. Tekintsük át a következőkben azt, hogy a nanoméretek világában milyen módon befolyásolhatók, szabályozhatók a félvezetők tulajdonságai a részecskék paramétereinek változtatásával.

A félvezető nanorészecskék mérete befolyással van azok optikai tulajdonságaira. Ugyanis ha valamely félvezető anyag részecskeméretét csökkentjük, fokozatosan megnövekszik a tiltott sáv energiája (1. ábra), igen kis részecskeméreteknél fellép az ún. méret kvantálási effektus. Ez azt jelenti, hogy az elektron vezetési sávba történő gerjesztéséhez egyre kisebb hullámhosszú, azaz egyre nagyobb energiájú fény szükséges. Ez a részecskék abszorbancia spektrumának a kisebb hullámhosszak felé történő eltolódásában (kék eltolódás) nyilvánul meg. 


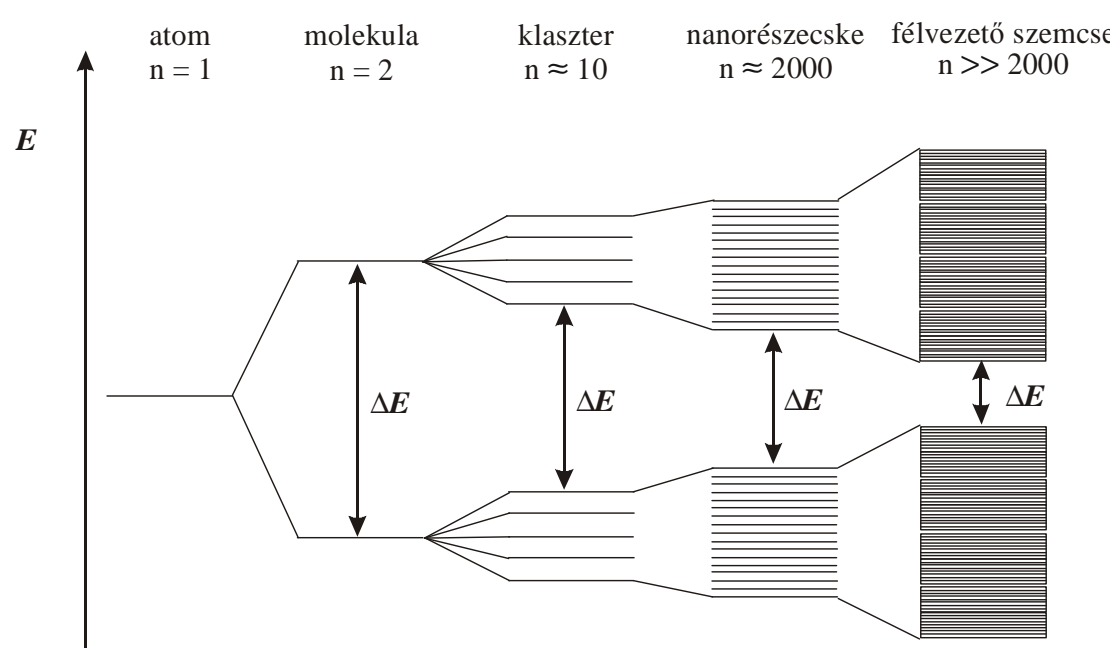

1. ábra A félvezető anyagok elektronszerkezete a részecskét alkotó atomok számának függvényében

A méret kvantálási effektus megjelenése akkor várható, ha az exciton Bohr-sugara (az elektron-lyuk pár legvalószínübb távolsága) megegyezik, vagy nagyobb, mint a részecske sugara [4] (2. ábra). A részecskeméret és a gerjesztési küszöbenergia között L. Brus által megalkotott egyenlet teremt összefüggést [5]:

$$
\mathrm{E}_{\mathrm{g}}=\mathrm{E}_{\mathrm{g}, \text { tömbi }}+\frac{\mathrm{h}^{2}}{2 \mathrm{~d}_{\mathrm{p}}{ }^{2}}\left(\frac{1}{\mathrm{~m}_{\mathrm{e}}}+\frac{1}{\mathrm{~m}_{\mathrm{h}}}\right)-\frac{3.6 \mathrm{e}^{2}}{4 \pi \varepsilon \mathrm{d}_{\mathrm{p}}}
$$

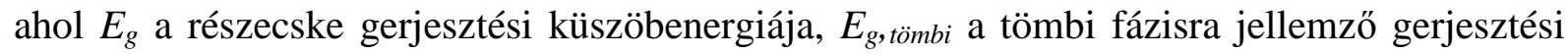
küszöbenergia, $h$ a Planck-állandó, $d_{p}$ a részecske átmérője, $m_{e}$ az elektron effektív tömege, $m_{h}$ a lyuk effektív tömege, $e$ az elektron töltése, $\varepsilon$ a félvezető relatív permittivitása.

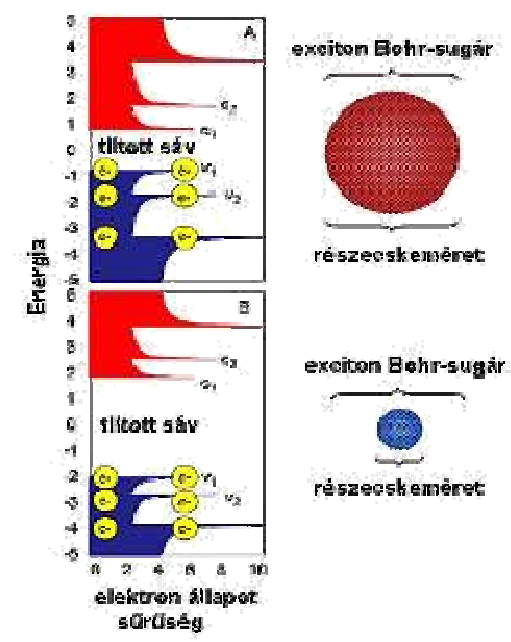

2. ábra A részecskeméret és az exciton Bohr-sugár arányának hatása a tiltott sáv nagyságára 


\subsection{A cink-oxid, mint félvezető nanorészecske}

\subsubsection{A cink-peroxidról és cink-oxidról általánosságban}

A cink-peroxid sárgásfehér por. Előállítható cink-acetát-dihidrát és hidrogén-peroxid reagáltatásával, ultraibolya besugárzás mellett [70]. Gerjesztési küszöbenergiája 3.7-4.5 eV [6,7]. Az egyik legfontosabb ipari alkalmazása karboxilált nitril-gumi és egyéb elasztomerek keresztkötéseinek kialakulásának elősegítése [8]. Alkalmazzák még antiszeptikus kenőcsök adalékanyagaként, de robbanószerek és pirotechnikai keverékekben oxidánsként is [9]. A vékonyréteg technikában főként cink-oxid filmek prekurzoraként terjedt el [10].

A cink-oxid finom eloszlású fehér por, természetben előforduló formája a hexagonális rácsszerkezetű cinkit (3. ábra). Amfoter jellegü, savakban való oldásakor a megfelelő cink-só, míg lúgokban való oldásakor $\left(\left[\mathrm{Zn}(\mathrm{OH})_{3}\right]^{-}\right.$és $\left[\mathrm{Zn}(\mathrm{OH})_{4}\right]^{-}$komplexek képződnek [3]. A cinkoxid félvezető oxid, gerjesztési küszöbenergiája 3.37 eV [11,12], exciton Bohr-sugara 2.34 nm [13]. Ha a rácsba fölösleges mennyiségű cinket építenek be, a rácshibaként jelentkező cink atomok a látható fény energiájával gerjeszthetővé válnak, így változatos, zöld-, sárga-, barna-, vörös színű cink-oxid állítható elő.
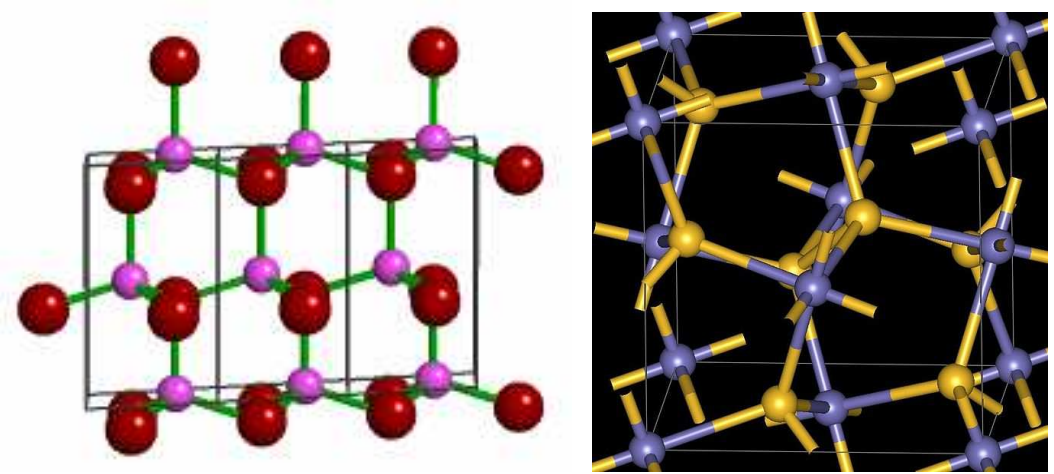

3. ábra A hexagonális cink-oxid (bal oldalon) és a köbös cink-peroxid rács (jobb oldalon)

A cink-oxid előállítható a cink levegőn történő hevítésével, cink-hidroxid, cink-karbonát, cink-peroxid vagy cink-oxalát hevítésével. Legfontosabb ipari felhasználása a gumigyártásban van, ahol a vulkanizálási idő csökkentésére használják, de alkalmazzák a műanyagiparban töltőanyagként, a kozmetikai iparban arcfestékek alapanyagaként, a gyógyszeriparban kenőcsök segédanyagaként.

Vegyipari jelentősége: cinktartalmú vegyületek előállításának kiindulási vegyületeként szolgál. Továbbá félvezető-, és rendkívüli optikai tulajdonságainak köszönhetően alkalmazzák napelemekben [14,15,16,17], gáz szenzorként [18,19,20,21,22,23], fénykibocsátó diódákban (LED). 


\subsubsection{Nanoszerkezetü cink-peroxid és cink-oxid előállítása}

Az utóbbi évtizedekben számos módszer vált ismertté szabályozott méretü $\mathrm{ZnO}$ nanorészecskék előállítására. A cink-oxid tulajdonságai a részecskék méretével és alakjával igen jól szabályozhatók, így minél inkább célszerü törekedni monodiszperz rendszerek szintézisére, hogy a kialakult fizikai és kémiai paraméterek is minél szükebb tartományban változzanak.

Egy közkedvelt módszert cink-oxid nanorészecskék előállítására Bahnemann és munkatársai dolgozták ki a nyolcvanas évek végén [24]. A szintézis során cink-acetát 2-propanolos oldatának lúgos hidrolízisével állítottak elő ZnO szolokat. Az előállítás során folyamatosan követték a részecskék fényelnyelését, s azt tapasztalták, hogy közel 2 óra elteltével a részecskék abszorpciós spektruma tovább nem változott, azaz a reakció teljesen végbement. A mintát transzmissziós elektronmikroszkóppal vizsgálva megállapították, hogy a szintézis eredménye $5 \pm 0,5 \mathrm{~nm}$-es gömb alakú, monodiszperz részecskékből álló diszperzió. A kilencvenes évek elején Spanhel és Anderson szol-gél technológiát alkalmaztak, mellyel különböző stabilitású cink-oxid nanodiszperziókat állítottak elő. Cink-acetát lítiumhidroxiddal végzett hidrolízisével, etanolos közegben állítottak elö cink-oxidot [25]. Tapasztalatuk szerint a keletkező diszperziók stabilitását, a részecskék méretét, alakját jelentősen befolyásolja az adagolt $\mathrm{LiOH}$ mennyisége, azaz a lúg és a cink ionok mennyiségének aránya. A témában jelentős eredményeket értek el Diaz és munkatársai is, akik szerves közegű homogén nukleációval állítottak elő 2-3 nm átméröjü fluoreszkáló cinkoxid részecskéket. Közegként dimetil-formamidot, illetve dimetil-szulfoxidot, prekurzorként cink-ciklohexán-butirátot, ill. cink-acetátot alkalmaztak [26]. Azt találták, hogy a ciklohexánbutirát anion stabilizáló hatása nagyobb, mint az acetátionoké, ill. hogy a dimetil-szulfoxid molekulák segítik az anionoknak a nanorészecskék felületén bekövetkező adszorpcióját.

A nanorészecskék stabilizálása megvalósítható rétegszilikátok segítségével is. Németh és munkatársai ún. „in situ” eljárással aluminoszilikátok, mint pl. kaolinit és montmorillonit, interlamelláris terét nanoreaktorként használva állítottak elő kontrollált méretü $\mathrm{ZnO}$ nanorészecskéket [27].

Folyadék közegben történő elöállítás során gyakori a stabilizáló szerek alkalmazása, melyekkel elkerülhető a keletkező, nagy felületi energiával rendelkező nanorészecskék spontán aggregációja, így szabályozott méretü $\mathrm{ZnO}$ nanorészecskék állíthatók elő. Szabályozott méretü nanorészecskéket lehet elöállítani ily módon pl. bór-nitrid nanokapszulákban [28], mikroemulziókban [29], inverz micellákban [30], tenzidek [31] és 
polimerek felhasználásával. Mivel valamely hordózó felületén periodikusan vagy aperiodikusan rendezett fém és fém-oxid nanoszerkezetek nanoméretüknél fogva előnyös fizikai, kémia és biológiai tulajdonságokkal rendelkezhetnek, alkalmasak lehetnek adathordozók [32] és bioszenzorok létrehozására. Azonban fontos feltétel, hogy a nanorészcskék megfelelő méretüek, monodiszperzek, térben pontosan pozícionáltak legyenek [33]. Egy másik közkedvelt és egyszerű eljárás különböző morfológiájú (prizma, virág stb.) részecskék előállítására a hidrotermális eljárás. A hidrotermális eljárás során a prekurzorok vizes oldatát néhány órás hőkezelésnek vetik alá, amely során a sztöchiometriától és a kísérleti körülményektől függően különböző alakú, méretű és kristályossági fokú részecskék keletkeznek. Yu és munkatársai cink-acetát, nátrium-hidroxid és különböző mennyiségü poli(sztirol-szulfonát)-ot (PSS) tartalmazó vizes oldatának autoklávban $180{ }^{\circ} \mathrm{C}$-on 2 órág tartó hőkezelése során állítottak elő $\mathrm{ZnO}$ részecskéket [34]. Kísérleteik során azt tapasztalták, hogy a rúd alakú részecskék hossza a PSS mennyiségének növelésével jelentősen csökkent (mivel a keresztmetszettel összemérhető hosszúságú rudakról beszélünk, ezért ezek már lemezek), melyek néhány $10 \mu \mathrm{m}$ átmérőjű, gömb alakú részecskékké állnak össze. Nátrium-citrát jelenlétében $120{ }^{\circ} \mathrm{C}$-on, 8 órás hőkezelés során állítottak elö $50-70 \mathrm{~nm}$ vastagságú nanolemezkékből felépülő, 2,5 $\mu \mathrm{m}$ átméröjü fánk alakú részecskéket Liang és munkatársai [35]. A fánk alakú szerkezet kialakulását a szerzők azzal magyarázzák, hogy a citrátionok képesek a cinkionok szállítására, ezáltal tudják koordinálni a cinkionok megfelelő kristálysíkra történő épülését. Egy mexikói kutatócsoport a reakcióelegy kezdeti és vég pH-ja közötti különbséggel befolyásolta a keletkező ZnO részecskék alakját [36]. Ni és munkatársai egy anionos tenzid, a nátrium-dodecil-szulfát (NaDS) jelenlétében készítettek nanopelyhekből álló, különböző átméröjű virág alakú részecskéket 10 órás $150{ }^{\circ} \mathrm{C}$-os hidrotermális eljárás során, melyek az előállítás során virág alakú nagyobb „,aggregátumokká” rendeződtek [37].

A cink-peroxid egyre nagyobb teret kap a nanoszerkezetü anyagok kutatásában és a vékonyréteg technikában, miután a kutatók felismerték, hogy könnyen előállítható és kezelhető prekurzora a cink-oxidnak [10]. A $\mathrm{ZnO}_{2}$ szintén egy félvezető oxid, melyet főleg a gumiiparban [38,39,40], müanyagiparban [41,42], robbanó anyagokban oxigén donorként [43], kozmetikai iparban [44] és a gyógyszeriparban [45] használnak. Sun és munkatársai cink-acetát hidrogén-peroxidos oldatának Xe-lámpával történő bevilágításával fotokémiai reakció során állítottak elő cink-peroxidot [46]. A folyamat végén $\mathrm{kb} .100 \mathrm{~nm}$ átmérőjü $\mathrm{ZnO}_{2}$ részecskék keletkeznek. Vizsgálták a termék kristályszerkezetét különböző hőmérsékleteken történő hőkezelés után: $200{ }^{\circ} \mathrm{C}$ alatt csak köbös szerkezetü $\mathrm{ZnO}_{2}$ fázis van jelen, azonban 
$200{ }^{\circ} \mathrm{C}$-feletti hőmérsékleten kezelve a $\mathrm{ZnO}_{2}$ tiszta hexagonális cinkit rácsszerkezetü, kb. 70 nm-es részecskemérettel rendelkező cink-oxiddá bomlott a következő egyenlet szerint:

$$
\mathrm{ZnO}_{2} \rightarrow \mathrm{ZnO}+1 / 2 \mathrm{O}_{2}
$$

Zhang és munkatársai hidrotermális kezelést alkalmazva állítottak elő 6 nm-es cinkperoxid részecskéket cink-acetátból és hidrogén-peroxidból kiindulva [47]. A terméket szárítás után $180{ }^{\circ} \mathrm{C}$-on hőkezelték, mely során 8-10 nm átmérőjű cink-oxid nanorészecskék keletkeztek.

Cink-peroxid előállítása során is alkalmazhatnak különböző stabilizáló polimereket. Ilyen például a poli(etilén-glikol) (PEG), melynek a részecskék morfológiájára gyakorolt hatását Rosenthal-Toib és munkatársai vizsgálták [48]. Ugyanazon kísérleti körülmények között ún. oxidációs-hidrolízises precipitációval állítottak elő cink-peroxid nanorészecskéket cink-acetát prekurzorból kiindulva PEG jelenlétében, ill. jelenléte nélkül. Dinamikus fényszórás méréssel határozták meg a keletkezett $\mathrm{ZnO}_{2}$ részecskék hidrodinamikai átmérőjét, amely a PEG jelenlétében ca. $20 \mathrm{~nm}$, míg PEG nélkül $200 \mathrm{~nm}$ volt. A beszárított $\mathrm{ZnO}_{2}$ pormintákat $300{ }^{\circ} \mathrm{C}$ 10 óráig hőkezelték, majd megvizsgálták a keletkezett $\mathrm{ZnO}$ részecskék morfológiáját. PEG jelenlétében előállított $\mathrm{ZnO}_{2}$-ból kalcinálás hatására kb. 10 nm-es átmérőjü primer részecskékből álló pórusos szerkezetű 500 nm-es ZnO aggregátumok, míg a PEG nélkül előállított minta hőbontása során 550 nm-es, tömör szerkezetü aggregátumok keletkeztek.

\section{4. Önrendeződő vékonyrétegek előállítása és tulajdonságai}

Vékonyrétegek előállítására változatos módszerek állnak a kutatók rendelkezésére: a kémiai gőzleválasztás (CVD) [49,50,51], a kémiai fürdő leválasztás [57], az elektrokémiai leválasztás [52,53], a centrifugális erő segítségével történő filmképzés (spin-coating) [54], a Langmuir-Blodgett (LB) [55,56,57,58], technika, a katódporlasztásos eljárás [59,60,61,62,63,64,65,66,67,68], és az önrendezéses technika (Layer-by-Layer, LbL), amely kitünően alkalmazható hibrid vékonyrétegek előállítására. Az önrendeződéses technika igen elterjedt és népszerü vékonyréteg készítési eljárás (pl. nem igényel extrém körülményeket, nagyvákuumot sok egyéb eljárással ellentétben), továbbá lehetővé teszi, hogy a félvezető nanorészecskéket a lehető legkülönfélébb anyagokkal - mint a polielektrolitok [69], agyagásvány [70,71], szilika részecskék [72] stb. - kombináljuk. A LbL módszer témájában alapvető fontosságú Decher és munkatársainak egy korai dolgozata, melyben anionos és kationos polielektrolitok felváltott adszorpciójával készített polielektrolit multirétegek (Polyelectrolite Multilayers-PEM) preparálásáról számolnak be. Polianion pozitív töltésü 
síkfelületen való adszorpciója a viszonylag magas koncentrációknak köszönhetően negatívvá tölti át a felületet, melyre adszorbeáltatva a polikationt újabb áttöltés valósul meg, s ezt ismételve akár 100 réteg felépítése is lehetséges [73]. Polielektrolitok mellett proteinek, ill. gömb alakú vagy lamellás nanorészecskék felhasználásával úgynevezett hibrid vékonyrétegek készíthetők. Szintén úttörő jelentőségü Kotov és munkatársainak munkája [74], melyben polielektrolitok és félvezető nanorészecskék felhasználásával építettek önszerveződő vékonyrétegeket. Spektroszkópiai módszerekkel, valamint transzmissziós elektronmikroszkópiai, atomerő mikroszkópiai és röntgen diffrakciós mérésekkel igazolták a filmek rendezettségét. Egy másik munkájukban grafit-oxid (GO)/polimer LbL rétegeket készítettek, majd ezt követően a grafit-oxid redukciójával vezető grafitszerü fázist hoztak létre, a redukciót elektrokémiai módszerekkel követve [75]. Szabó és munkatársai szintén grafit-oxidból és polielektrolitból építettek hibrid filmeket, melyekben redukcióval és hőkezeléssel reverzibilisen valósították meg a vezető és nem-vezető állapot közti váltást [76,77]. Cassier és csoportja sztreptavidin felhasználásával készítettek önszerveződő filmeket, megállapítva, hogy a protein jelentősen növeli a felület durvaságát, mely fontos paraméter a vékonyréteg technológiában [78]. Sukhorukov és munkatársai DNS tartalmú polielektrolit filmekben tanulmányozták és a rétegek számával szabályozták DNS-specifikus festékek filmbe diffundálását [79]. Ultravékony polielektrolit filmeken keresztüli transzport tanulmányozásáról számolt be Klitzing és Möhwald, melynek során, mintegy szürőként viselkedve nagyobb molekulák átjutását akadályozta, míg kisebb molekulákét engedte a polielektrolit film, melyhez csatolt festék fluoreszcenciáját mérve detektálták a transzport mennyiségét [80]. Kunitake csoportja különböző specifikus enzimek, montmorillonit ill. ellentétes töltésű poliionok váltakozó adszorpciójával hozott létre önrendeződő hibrid rendszereket, megállapítva, hogy az ellentétes töltés vagy ellentétes specifikusság kulcskérdése a technikának [81]. Egy másik munkában tanulmányozták $\mathrm{SiO}_{2} / \mathrm{PDDA}$, montmorillonit/PEI és molibdén-oxid (MO)/PAH hibrid rendszerek felépülésének kinetikáját, s megállapították, hogy míg a szférikus szilika részecskék adszorpciója másodpercek alatt telítődött, a nehezebben rendeződő agyagásvány esetén 5-6 perc volt, míg a MO esetében nem mutatott telítést [82].

Réteges kettős hidroxidok (LDH) is jól alkalmazhatók önszerveződő filmek készítésére [83,84,85]. Aradi és munkatársai különböző LDH-kból és polianionokból készítettek vékonyrétegeket LbL illetve ún. „spin coating” módszerekkel, és megállapították, hogy a diffúzió kontrollált önrendeződéssel előállított rétegek jóval rendezettebbek és stabilabbak, mint a mechanikai kényszer alatt épülő filmek [86]. Klitzing és csoportja hőmérséklet- és pH- 
érzékeny önszerveződő PNIPAAM rendszereket készített, melyek szerkezeti és szenzorikus tulajdonságait vizsgálták [87]. Egy másik munkában szintén PNIPAAm-co-PAA kopolimer mikrogélekből állítottak elő hőmérséklet-érzékeny felületeket, melyek duzzadását ellipszometriával és atomerő mikroszkóppal vizsgálták [88]. Megállapították, hogy az eredetileg $30 \mathrm{~nm}$ vékony filmek közel tizenháromszorosukra duzzadtak. Schönhoff és munkatársai szintén vizsgálták kvarckristály mikromérleggel, röntgen-reflektivitással („X-ray reflectivity”) és magmágneses rezonanciával (NMR) az önrendeződő technikával készített polielektrolit multirétegek preparálását, duzzadását, hidratációját és a belső szerkezeti tulajdonságait [89].

Az LbL módszer nem csak vékonyréteg technikában bizonyult kitünő eljárásnak, hanem ún. mag-héj szerkezetü mikrokapszulák előállításában is. Möhwald csoportja nanométertől milliméterig eső tartományban lévő méretű, nanométeres falvastagságú nanokapszulákat állított elő és tanulmányozott [90]. Polianionok és polikationok negatív töltésű kolloid részecskére történő váltakozó adszorpciója után a részecskét eltávolították (pl. kioldással), az eredmény pedig egy polielektrolit héj volt, mely különböző hatóanyagokkal feltölthetővé vált. A polielektrolitok gondos megválasztásával a kapszula permeábilitása és mechanikus tulajdonságai hangolhatók [91,92].

\subsection{Vékonyrétegek optikai tulajdonságainak meghatározására szolgáló módszerek}

Nanofilmek jellemzésére számos módszer fellelhető az irodalomban. A teljesség igénye nélkül áttekintem ezek közül a legelterjedtebb módszereket.

Swanepoel a '80 években egy korai munkájában ismertetett egy módszert, mellyel vékonyrétegek optikai állandóit adta meg [111]. A technika lényege, hogy egy nulla és egy nem nulla beesési szöghöz tartozó reflexió spektrum szélsőértékeiből numerikus eljárással számítja a rétegvastagságot és a törésmutató értékeit a szélsőértékekhez tartozó hullámhosszakon. A módszer hátránya, hogy csak olyan esetekben alkalmazható, amikor a reflexió spektrum legalább 4-5 szélsőértékkel rendelkezik, mert egyenesek illesztése útján határozza meg az állandókat, ehhez természetesen legalább 4-5 pontra van szükség. Egy másik általa kidolgozott módszerben [93,94,95,96,97] a transzmittancia spektrum burkológörbéinek segítségével határozta meg ezeket az állandókat oly módon, hogy mind a minimum-, mind a maximum helyekre illesztett görbék jelentik a burkológörbét, s ennek adataiból viszonylag egyszerü összefüggésekkel határozza meg a hullámhossz-függő optikai állandókat s a rétegvastagságot. 
A fenti, transzmittancia spektrumból dolgozó módszerek mellett igen elterjedt és megbízható technikának számít az ellipszometria, amely egy olyan, érintés- és roncsolásmentes optikai vizsgálati módszer, amellyel a nagyon vékony, akár nanométeres vastagságú rétegek, dielektrikumok optikai tulajdonságait lehet mérni, az anyag felületére bocsátott, majd onnan visszaverődő polarizált fényt vizsgálva. Az ellipszometriában a fény polarizációjának változásából nyerhető információ, ahol a vizsgáló fény hullámhosszánál vékonyabb rétegek vizsgálhatók, akár egy atom vastagságig. A vizsgálat a komplex törésmutató vagy a dielektrikus függvény tenzorát értékeli ki, amelyek alapvető paraméterekröl adnak információt, mint például morfológiára, kristály minőségre, kémiai összetételre, vagy az elektromos vezetőképességre [98]. A vizsgálatot számos területen alkalmazzák a félvezetőipartól [96,99,100] a biológiáig [101,102,103].

A fenti elméletek egy konstans rétegvastagsággal rendelkező homogén közeget tekintenek modellként. Amennyiben a film nem homogén (több komponensü, vagy pórusos), akkor az irodalomban fellelhető számos metódus valamelyikével homogenizálható. Ezek közül a legelterjedtebbek: Maxwell Garnett közelítés [104,105,107], Bruggeman formula [106,107], Looyenga-féle közelítés [108].

Fellelhető az irodalomban olyan modell is, amely nem konstans rétegvastagsággal számol - olyan esetekben, amikor a rétegvastagság változása azonos nagyságrendbe esik magával a rétegvastagsággal. Ennek során valamilyen eloszlásfüggvénnyel definiálja a változásokat, majd a reflektancia spektrumokat az eloszlásnak megfelelő rétegvastagságokon mérhető görbék összegeként állítja elő [109]. 


\section{Anyagok és módszerek}

“A munka láthatóvá vált szeretet. Ha nem tudtok szeretettel, hanem csak kedvtelenül dolgozni, akkor jobban tennétek, ha abbahagynátok, és kiülnétek a templom lépcsöjére alamizsnát koldulni azoktól, akik örömmel dolgoznak.”

(Kahlil Gibran)

\subsection{Kísérleti anyagok}

\subsubsection{Cink-peroxid előállítása}

A cink-peroxid $\left(\mathrm{ZnO}_{2}\right)$ szolt cink-acetát-dihidrát $\left(\mathrm{C}_{4} \mathrm{H}_{6} \mathrm{O}_{4} \mathrm{Zn} \cdot 2 \mathrm{H}_{2} \mathrm{O}\right.$ Fluka, a.r.) fotolízisével állítottam elő. A szintézis során kvarc edényben $300 \mathrm{ml}$ ioncserélt vízben $6 \mathrm{~g}$ cink-acetátdihidrátot oldottam fel, majd $10 \mathrm{ml} 30$ V/V\% töménységü hidrogén-peroxid oldatot $\left(\mathrm{H}_{2} \mathrm{O}_{2} 30 \%\right.$-os vizes oldat, Ph.Eur.5.0.) adtam a rendszerhez. Ezt követően az oldatot kevertetés közben 4 órán át $75 \mathrm{~W}$ teljesítményü Xe-lámpával világítottam be. A szintézis félidejében újabb $10 \mathrm{ml}$ hidrogén-peroxid oldatot adagoltam be. A bevilágítás végére fehér színü diszperzió keletkezett, melynek koncentrációja 8.5 g/L, pH-ja 5.1.

A vizes közegü cink-peroxid szol koncentrációja: $0.85 \%(g / L)$

\subsubsection{Cink-oxid előállítása}

Az elkészített $\mathrm{ZnO}_{2} / \mathrm{Na}$-hektorit vékonyrétegeket 4 órán keresztüli $400{ }^{\circ} \mathrm{C}$ hőmérsékletü hőkezelésnek vetettem alá, melynek eredményeképpen cink-oxid tartalmú filmeket nyertem.

\subsubsection{Kötőanyagként használt szervetlen (részecskék) és szerves (polimer) kolloidok}

A [cink-peroxid (ill. cink-oxid) / lineáris polimer ill. rétegszilikát] filmek szerves kötőanyaga poli(sztirolszulfonát) (PSS, Sigma, a.r., $\mathrm{M}_{\mathrm{w}} \sim 70$ 000), szervetlen kötőanyaga szintetikus Na-hektorit (Optigel ${ }^{\mathrm{R}}$, Süd-Chemie $\left.\mathrm{GmbH}\right)$, a filmek hordozója pedig mikroszkóp tárgylemez (Menzel Superfost) és szilícium lapka (Filmtronics Inc.) volt.

A PSS oldat koncentrációja: $0.01 \%(\mathrm{~g} / \mathrm{L})$

A Na-hektorit szuszpenzió koncentrációja: $0.1 \%(\mathrm{~g} / \mathrm{L})$

A cink-peroxid/térhálós polimer filmek készítésekor monomerként N-izopropilakrilamidot (NIPAAm) $\left(\mathrm{H}_{2} \mathrm{C}=\mathrm{CHCONHCH}\left(\mathrm{CH}_{3}\right)_{2}\right.$, Aldrich, 97\%) és akrilamidot (AAm) 
$\left(\mathrm{CH}_{2}=\mathrm{CHCONH}_{2}\right.$, Reanal, purum), míg térhálósítóként N,N-metilén-biszakrilamidot (BisAAm) $\quad\left(\left(\mathrm{H}_{2} \mathrm{C}=\mathrm{CHCONH}_{2}\right)_{2} \mathrm{CH}_{2}\right.$, Aldrich, 99\% $)$ használtam. A fotopolimerizációs reakciók során a fotoiniciátor Irgacure $651\left(\mathrm{C}_{6} \mathrm{H}_{5} \mathrm{COC}\left(\mathrm{OCH}_{3}\right)_{2} \mathrm{C}_{6} \mathrm{H}_{5}\right.$, Aldrich, 99\%) volt. Polimerizációs közegként desztillált vizet használtam. A filmek hordozója mikroszkóp tárgylemez (Menzel Superfrost) ill. arany bevonatú kvarc kristály (Scientific Instruments $\mathrm{GmbH})$ volt.

A NIPAAm oldat koncentrációja: $1 \mathrm{M}$

Az AAm oldat koncentrációja: $1 \mathrm{M}$

A BisAAm oldat koncentrációja: $0.05 \mathrm{M}$

\subsubsection{Felületmódosító anyagok}

A felületmódosítások során butil-triklórszilán (BTS, Fluka) hexános oldatát ill. oktántiollal (Aldrich) borított nanoarany szolt használtam fel. Az oktántiollal módosított arany előállítása Brust-szintézissel [110] történt, a részecskék átmérője átlagosan $2 \mathrm{~nm}$.

A butiltriklórszilán oldat koncentrációja: $0.01 \mathrm{M}(0.19 \%)$

Az oktántiollal borított nanoarany szol koncentrációja: $0.01 \%$

\subsection{A vékonyrétegek készítése}

\subsubsection{Cink-peroxid/PSS és cink-peroxid/Na-hektorit vékonyrétegek készítése}

A vékonyrétegeket ún. önrendeződéses (Layer-by-Layer self assembly, LbL) bemerítéses technikával állítottam elő (4. ábra). A hordozókat a filmépítés megkezdése előtt krómkénsavban tisztítottam- hogy a lemezek felületén megtapadt szennyeződéseket eltávolítsam-, majd ioncserélt vízzel mostam, nitrogén gáz áramban szárítottam. A megtisztított, száraz hordozókat a $\mathrm{ZnO}_{2}$ szolba merítettem. Tíz perc adszorpciós időt követően a lemezeket $0.3 \mathrm{~cm} / \mathrm{s}$ kiemelési sebességgel eltávolítottam a szolból, majd ioncserélt vízzel mostam és nitrogén gáz árammal szárítottam. Ezt követően a - már egy cink-peroxid réteget tartalmazó hordozókat a $0.01 \%$ koncentrációjú PSS-oldatokba ill. a $0.1 \%$ koncentrációjú Na-hektorit szuszpenziókba merítettem. Az adszorpciós idő (10 perc) letelte után a lemezeket $0.3 \mathrm{~cm} / \mathrm{s}$ kiemelési sebességgel eltávolítottam az oldatokból, amelyet az ioncserélt vizes öblítés után nitrogén gázzal történő szárítás követett. Ezt a két lépést $n$-szer ismételtem meg egymást követően, mely során $\left[\mathrm{ZnO}_{2} / \mathrm{PSS}\right]_{\mathrm{n}}$ ill. $\left[\mathrm{ZnO}_{2} / \mathrm{Na} \text {-hektorit }\right]_{\mathrm{n}}$ összetételü filmeket nyertem, ahol $n$ a rétegszám, értéke pedig $5,10, \ldots, 30$ volt. 


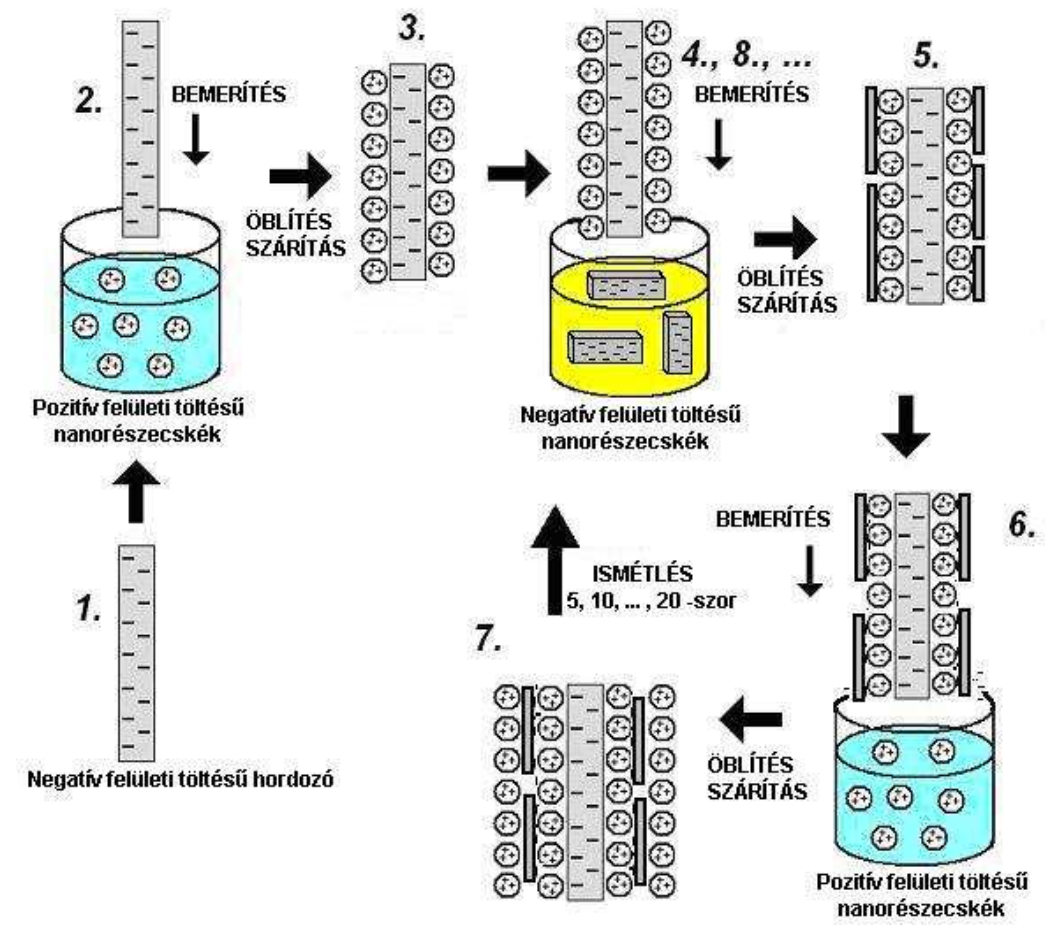

4. ábra $A z$ önrendezödéses ( $L b L)$ bemeritéses technika sematikus ábrája

\subsubsection{Cink-peroxid/térhálós polimer vékonyrétegek készítése fotopolimerizációval}

A cink-peroxid/térhálós polimer hibrid filmek elkészítése a 3.2.1. pontban leírtak alapján történt, csupán egy dologban tér el attól: a 4. ábra 4., 8., 12. stb. lépését az öblítés után fotoiniciátor oldatba való merítés, valamint újabb öblítés és szárítás követi, majd nitrogén atmoszférában történő 1 perces UV besugárzás történik, ugyanis a felületre tapadt monomerek ennek következtében polimerizálódnak térhálós szerkezetü makromolekulákká (5. ábra).

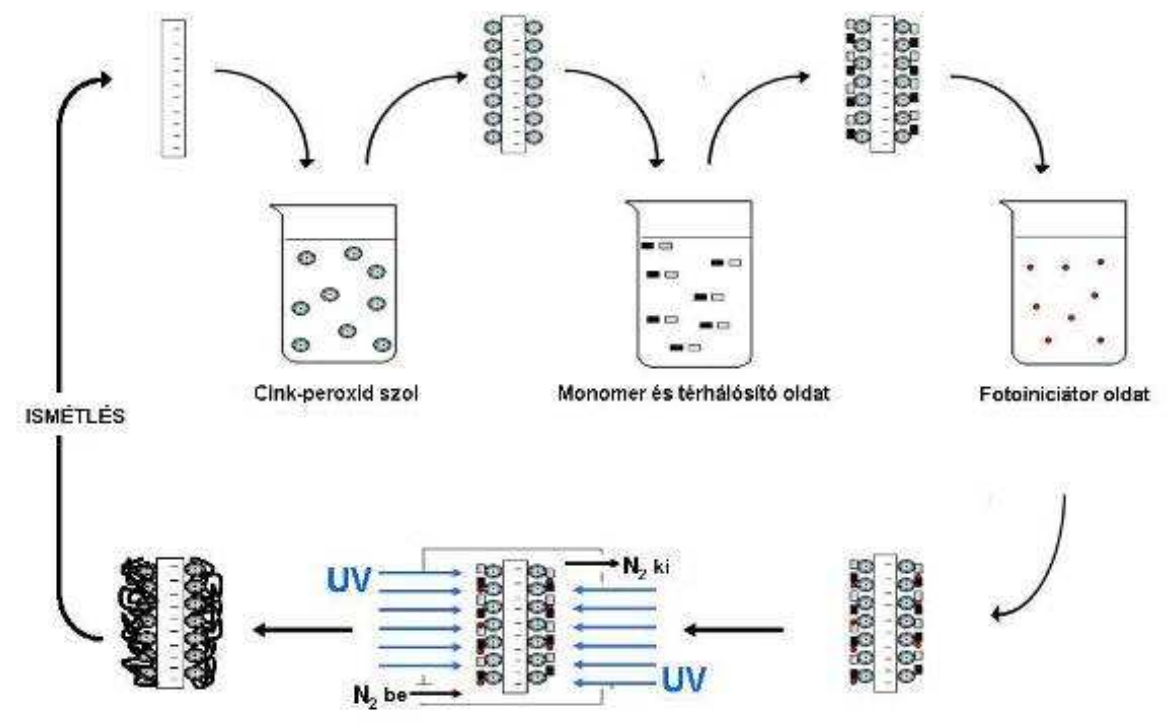

5. ábra Az „in-situ” fotopolimerizációval megvalósuló önrendeződéses technika sematikus ábrája 


\subsection{3. $\mathrm{ZnO}_{2} / \mathrm{PSS}$ vékonyrétegek felületmódosítása}

Az elkészített vékonyrétegek felületének módosítása butiltriklórszilán 0.01 M (0.19\%) hexános oldatából ill. oktántiollal borított nanoarany 0.01 \% hexán közegű szuszpenziójából való cseppentéssel történt. A $10 \mu \mathrm{L}$ térfogatú cseppeket $\sim 10 \mathrm{~cm}^{2}-\mathrm{es}$ területen $(2.5 \mathrm{~cm} \mathrm{x} 4 \mathrm{~cm})$ terítettem szét, majd a hexán elillanása után a filmeket nitrogén árammal (is) szárítottam.

\subsection{Vizsgálati módszerek}

\subsubsection{UV-vis abszorpciós spektrofotometria}

A kísérleteim során a cink-peroxid diszperzió, valamint a cink-oxid ill. cink-peroxid tartalmú vékonyrétegek UV-látható abszorpciós tulajdonságainak meghatározásához Ocean Optics USB2000 típusú diódasoros spektrofotométereket használtam. A diszperziók abszorbanciájának meghatározását kvarc küvettában végeztem.

\subsubsection{Röntgendiffrakció (XRD)}

Az előállított cink-peroxid és cink-oxid minták kristályszerkezetének azonosításához, ill. kristályossági fokuk, továbbá a többrétegű filmek felépülésének követéséhez nagyszögü röntgendiffrakciós berendezést alkalmaztam. A porminták méréseit Philips röntgendiffraktométerrel (PW 1830 generátor, PW 1820 goniométer, $\mathrm{CuK} \alpha$ sugárzás: $\lambda=0,1542 \mathrm{~nm}, 40-50 \mathrm{kV}, 30-40 \mathrm{~mA}, 1 \mathrm{~mm}$-es rés), ill Bruker D8 Advance diffraktométerrel (CuK $\alpha$ sugárzás: $\lambda=0.1542 \mathrm{~nm}, 40 \mathrm{kV}, 30 \mathrm{~mA}, 0.1 \mathrm{~mm}$-es rés ) szobahőmérsékleten végeztem. A diffraktogramok kiértékeléséhez a PW1877, ill. a Diffrac ${ }^{\text {plus }}$ Basic számítógépes programokat használtam. A (4) Scherrer-egyenlettel az átlagos primer részecskeátmérő $(D)$ számítható a mintára meghatározott vonalszélesség $\left(\beta_{S}\right)$ és a makrokristályos anyagra meghatározott vonalszélesség ( $\beta_{0}$, a müszerre jellemző vonalkiszélesedés) különbségével $(\beta=$ $\left.\beta_{S}-\beta_{0}\right)$, a röntgensugárzás hullámhosszának $(\lambda)$, a részecskealakra jellemző állandónak $(k=$ $0,9)$ és a vizsgált reflexió pozíciójának $(\Theta)$ ismeretében:

$$
\mathrm{D}=\mathrm{k} \lambda / \beta \cos \Theta
$$

\subsubsection{Dinamikus fényszórás mérés (DLS)}

A dinamikus fényszórás méréseket és elektrokinetikai potenciál (zeta-potenciál) méréseket Malvern gyártmányú Zetasizer NanoZs készülékkel végeztem. A beépített 
HeNe-lézer a megfigyelés síkjára merőlegesen polarizált, hullámhosszúsága 632.8 nm. A részecskeméret meghatározásához müanyag, ill. optikai üveg küvettákat, míg az elektrokinetikai-potenciál mérésekhez polisztirolból készült U-alakú kapilláris cellát használtam. A méréseket a Dispersion Technology Software (DTS Nano) 5.02 számítógépes program segítségével rögzítettem, amely a mérési eredmények kiértékelését is végzi.

\subsubsection{Termoanalitikai vizsgálatok (TG, DTA)}

A porminták termogravimetriai analízisét egy Mettler Toledo TGA/SDTA $851^{\mathrm{e}}$ típusú készülékkel végeztem. Az 5-10 mg mennyiségü mintákat $70 \mu \mathrm{l}$ térfogatú alumínium-oxid tégelybe mértem, melyeket azután szintén $25-1000{ }^{\circ} \mathrm{C}$ hőmérséklet tartományban, $5{ }^{\circ} \mathrm{C} /$ perc lineáris fütési sebesség alkalmazása mellett vizsgáltam. A mérési eredmények kiértékelését a Mettler Toledo STAR ${ }^{\mathrm{e}}$ v8.10 mérésvezérlő és értékelő számítógépes programmal végeztem.

\subsubsection{Atomerő mikroszkópia (AFM)}

Az előállított filmek morfológiai vizsgálatát atomerő mikroszkópia (AFM) segítségével végeztem. A képeket a Digital Instruments (USA) cég által gyártott Nanoscope III típusú készülékkel készítettem, mely pásztázó képessége $12,5 \mu \mathrm{m}$ az $x$ és $y$, és $3 \mu \mathrm{m}$ a $z$ irányokban. A mérések során tapogató módszernél használt tü (Veeco Nanoprobe Tips RTESP típusú, $125 \mu \mathrm{m}$ hosszú, 300 kHz) szilíciumból készült.

\subsubsection{A részecskék töltésállapotának jellemzése}

\section{Zéta-potenciál meghatározása}

A részecskék töltésállapotát jellemző elektrokinetikai (zéta)-potenciál meghatározását Nano-Zetasizer dinamikus fényszórásmérő készülék (Malvern, UK) kapilláris cellájában végeztem el. A müszer optikai rendszere a HeNe-lézer fényforrásból kiinduló fénysugárból azonos úthosszakat befutó, egymást keresztező, kölcsönösen koherens sugárnyaláb-párt hoz létre. Az elektroforézis cella arany elektródái között az elektromos mezőben mozgó részecskék a fotonokkal ütköznek és a mozgás irányától függően megváltoztatják a lézerfény frekvenciáját (Doppler-eltolódás). Az eltolódás mértékéből a részecskék sebessége, a cellában bekövetkező potenciálesés ismeretében pedig az elektroforetikus mobilitás ill. elektrokinetikai potenciál kiszámító 


\section{Áramlási potenciál mérés: felïleti töltés ekvivalencia értékek meghatározása}

A felhasznált kolloidok fajlagos felületi töltésének meghatározásához áramlási potenciál mérést alkalmaztam. Ezen kísérletek alapja, hogy a negatív felületi töltéssel rendelkező Nahektorit és PSS töltését kationos tenziddel (CTAB), a pozitív felületi töltéssel rendelkező $\mathrm{ZnO}_{2}$-ét pedig anionos tenziddel (NaDS) semlegesítjük. A titrálás során a hozzáadott ellentétes töltésű tenzid mennyiségét addig növeljük, míg az áramlási potenciál értéke eléri a nullát. A hozzáadott tenzid anyagmennyiségéből kiszámítható a kolloidok fajlagos töltése. A fajlagos töltéseket Mütek PCD 02-es töltés meghatározó detektorral határoztam meg. A hengeres teflonedényben periodikusan, $4 \mathrm{~Hz}$ frekvenciával függőleges irányban mozgatott teflon-oszlop a diszperziók részecskéit állandó jellegü, változó irányú mozgásban tartja. A részecskék körüli elektromos kettősréteg lenyírásából adódóan a töltésállapotra jellemző és a készülék mérőcellájának geometriai adataitól függő potenciálkülönbség mérhető a tefloncső falába ágyazott aranyelektródokon.

\subsubsection{Transzmissziós elektronmikroszkópia (TEM) mérések}

Az elektronmikroszkópos vizsgálatokat egy Philips CM-10 típusú transzmissziós elektronmikroszkóppal végeztem 100 kV-os gyorsító feszültséget alkalmazva. A mérések az SZTE Orvostudományi Kar, Anatómia és Patológiai Tanszék Elektronmikroszkópos Laboratóriumában történtek.

\subsubsection{A reflexió spektrumok rögzítése és kiértékelése}

A vékonyrétegek reflexió spektrumának felvételét minden esetben 0 ill. $45^{\circ}$-os beesési szögek alatt végeztem egy speciális, házi tervezésü optikai szálas cellában (6. ábra), Ocean Optics ADC1000-USB típusú diódasoros spektrofotométerrel és egy saját fejlesztésű (Borland DelphiT ${ }^{\mathrm{TM}}$ nyelven fejlesztett, a müszerrel USB porton kommunikáló) szoftverrel, mely egyben a reflexió spektrumok kiértékelését is végzi. Analitikus (trigonometrikus) görbéket illeszt a mért spektrumokra, s a paraméterek (porozitás, rétegvastagság stb.) változtatásával, a legjobb illeszkedést megtalálva kapjuk meg az eredményt, ami a hullámhosszfüggő törésmutató és a rétegvastagság. Tekintettel arra, hogy kettő ismeretlen van $(n(\lambda)$ és $d)$, kettő független spektrumra van szükség. A mérési adatok kiértékeléséhez bevezettem egy háromkomponensü (részecske, kötőanyag, pórus) szilárdtest modellt, valamint effektív közeg közelítést és kétsugaras interferencia modellt használtam fel a reflexió spektrumok analitikus görbékkel 
való illesztésére. Tekintettel arra, hogy a spektrumok kiértékelésére szolgáló módszer maga is önálló eredmény, ezért ennek részletes ismertetésére a 4. fejezetben térek ki.

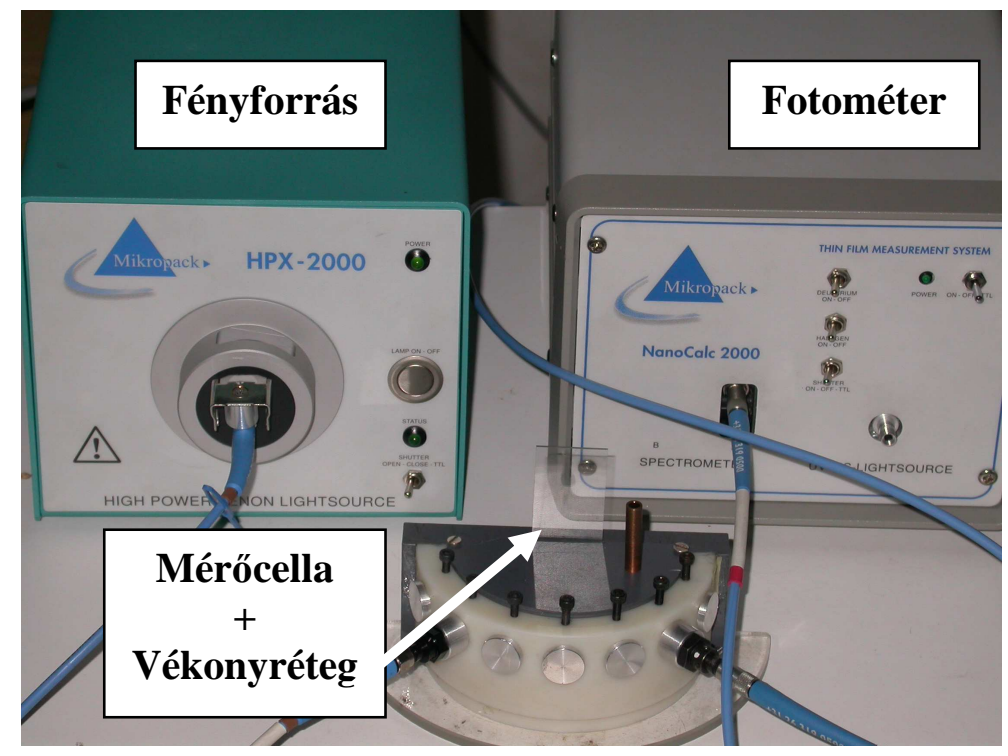

6. ábra A reflexió spektrumok rögzítésére szolgáló elrendezés (fényforrás, detektor és méröcella gáz ki-és bevezetéssel)

\subsubsection{Reflexió spektrumok mérésén alapuló gőzdetektálás}

A 3.3.8. bekezdésben ismertetett technika kiterjesztésén alapszik az optikai elven nyugvó gőzdetektálás elve. Alapja, hogy gőz adszorpció hatására a vékonyréteg törésmutatója megnövekszik (a pórusok törésmutatója különbözni fog a levegőétől, $n_{0}>1.000293$ ), ami a spektrumok eltolódását okozza a nagyobb hullámhosszak irányába. Ennek követése céljából kiépítettem egy gáz/gőz keverő és adagoló rendszert, mely a 6. ábrán található mérőcellához csatlakozik.

Kiszolgáló szoftvert fejlesztettem, mely másodpercenként számítja és rögzíti a gőz(ök) koncentrációját, valamint a reflexió spektrumok folyamatos felvételével és előzetes kalibráció felhasználásával a törésmutató értékét egy adott hullámhosszon. Ezáltal lehetővé válik mind a gőzkoncentráció mind a törésmutató időbeni követésére, egyúttal pedig a kettő kombinációjából a relatív gőznyomás-törésmutató változás $\left(p_{r}-\Delta n\right)$ függvény megadása. Amennyiben sikerül kvantitatív összefüggést találni a törésmutató és a fajlagos adszorbeált mennyiség között, akkor egy új típusú, optikai elven működő gőz/gáz szenzorról beszélhetünk, melyről - jelenlegi ismereteim szerint - az elérhető irodalomban nincs fellelhető információ. Ennek okán e módszer részletes ismertetésére is az „Eredmények és értékelés" c. fejezetben térek ki. 


\subsubsection{Pásztázó elektronmikroszkópos mérések (SEM)}

A pásztázó elektronmikroszkópos (SEM) felvételek a Hitachi S-4700 típusú téremissziós pásztázó elektronmikoszkóppal készültek az SZTE TTIK Elektronmikroszkóp Laboratóriumában.

\subsubsection{Kvarc kristály mikromérleggel végzett mérések $(\mathrm{QCM})$}

A vékonyrétegek felépülésének követését, ill. a vékonyrétegek adszorpciós izotermáinak mérését a Stanford Research System, QCM200 típusú kvarckristály mikromérleggel végeztem. A számítógépes vezérlés az SrsQcm200 típusú, gyári szoftverrel történt. A mérésekhez használt kvarc kristály króm/arany bevonattal volt ellátva, rezgési frekvenciája 5 MHz. A kvarckristály mérlegről általánosságban elmondható, hogy az adszorpció miatti frekvenciacsökkenés arányos a tömegnövekedéssel:

$$
\Delta \mathrm{m}=-\Delta \mathrm{f} * \mathrm{k}
$$

ahol $\Delta m$ a tömegnövekedés, $\Delta f$ a frekvenciacsökkenés és $k$ konstans, esetünkben $k=17.668 \mathrm{ng} / \mathrm{cm}^{2} \mathrm{~Hz}$.

\subsubsection{Peremszög mérés}

A vékonyrétegek nedvesíthetőségét a felületmódosítás után desztillált víz peremszögének meghatározásával jellemeztem. A mérésekhez a Krüss Easy Drop típusú permszögmérő berendezést és a Drop Shape Analysis típusú gyári szoftvert használtam. A mérés során desztillált víz $10 \mu \mathrm{l}$-es cseppjét cseppentettem a filmre, a kamerával fényképet készítettem a cseppről, majd a szoftver segítségével meghatároztam a jobb és baloldali peremszögeket, majd az átlagukat vettem figyelembe jellemző értékként. 


\section{Eredmények és értékelés}

“Tapasztalatainkból semmit sem tanulhatunk, csak abból, ha elgondolkozunk rajtuk.”

(Robert Sinclair)

\subsection{Cink-peroxid nanorészecskék előállítása és vizsgálata}

\section{Cink-peroxid nanorészecskék előállítása}

A cink-peroxid nanorészecskék vizes közegü előállítását a 3.1.1. pontban leírtak szerint hajtottam végre, cink-acetát-dihidrát fotolízisével. A folyamat során lejátszódó reakció a következö:

$$
\mathrm{Zn}\left(\mathrm{CH}_{3} \mathrm{COO}\right)_{2}+\mathrm{H}_{2} \mathrm{O}_{2} \rightarrow \mathrm{ZnO}_{2}+2 \mathrm{CH}_{3} \mathrm{COOH}
$$

\section{Cink-peroxid nanorészecskék UV-látható elnyelésének vizsgálata}

A 7. ábrán a cink-peroxid szol abszorbancia spektruma látható. Látható, hogy a cinkperoxid az ultraibolya hullámhossz tartományban rendelkezik elnyeléssel, gerjesztési küszöbértéke a szol abszorpciós spektrumából meghatározható: amely $\lambda_{\mathrm{g}}=329 \mathrm{~nm}$-nek, azaz $\mathrm{E}_{\mathrm{g}}=3.76 \mathrm{eV}$ energiának adódott. A szintézis egyes szakaszaiban rögzített abszorbancia spektrumok alapján megállapíthatjuk, hogy a 3.76 eV energiaérték a reakció végére alakul ki, a szintézis során fokozatosan csökken. 1 órával a reakció kezdete után $\mathrm{E}_{\mathrm{g}}$ értéke $4.46 \mathrm{eV}$, 2 óra elteltével $4.0 \mathrm{eV}$, s a $3.76 \mathrm{eV}$ értéket a reakció végén, 4 óra elteltével éri el (8. ábra). Ezek az értékek minden bizonnyal a szintézis folyamán növekedő részecskemérettel arányosan csökkenő energiák (méret kvantálási effektus).

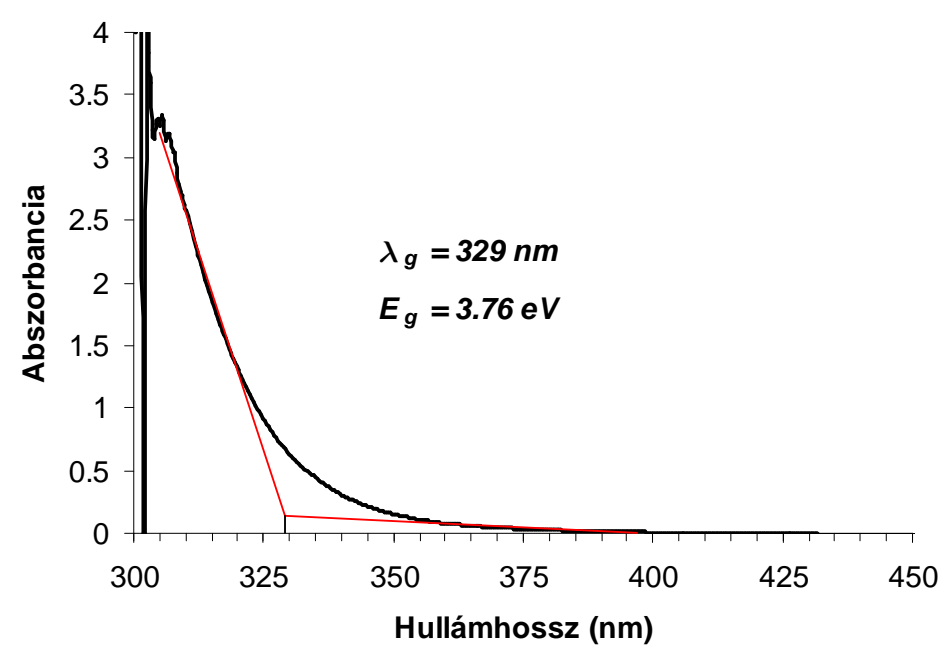

7. ábra $\mathrm{A} 8.5 \%$ koncentrációjú $\mathrm{ZnO}_{2}$ szol abszorbancia spektruma a 4 órás reakció végén 


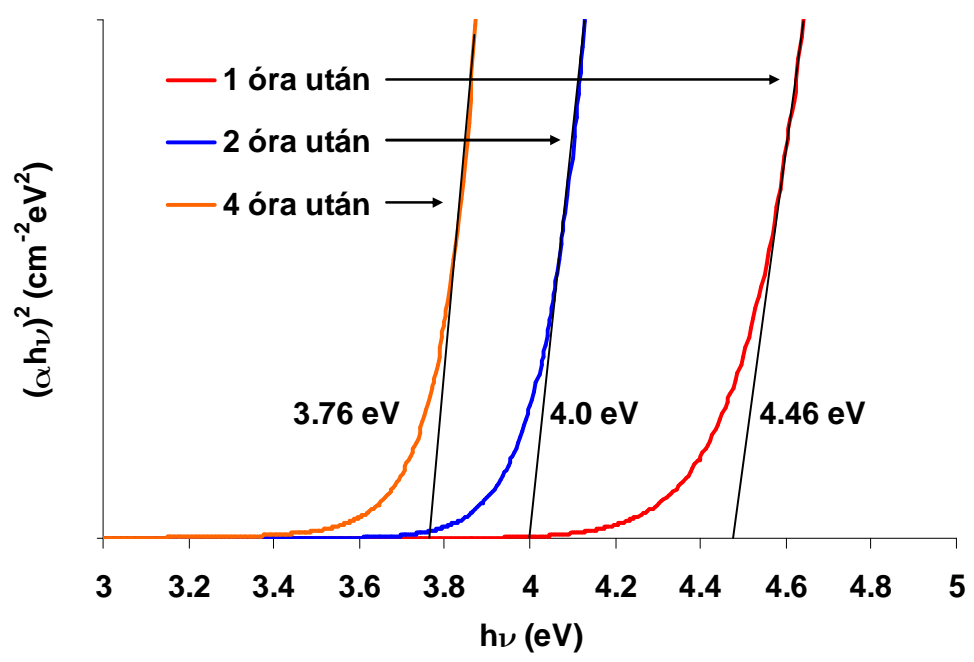

8. ábra $A 8.5 \%$ koncentrációjú $\mathrm{ZnO}_{2}$ szol abszorbancia spektrumai a reakció során 1,2 és 4 óra elteltével, Tauc-reprezentációban

\section{Cink-peroxid nanorészecskék szerkezetvizsgálata röntgen diffrakcióval (XRD)}

A cink peroxid szol $50{ }^{\circ} \mathrm{C}$ hőmérsékleten történt beszárításával nyert pormintát XRD vizsgálatnak vetettem alá. A diffraktogramon $30-40^{\circ} 2 \Theta$ szögtartományban két csúcs jelenik meg: $31.76^{\circ}{ }^{\circ}$-nál és $36.85^{\circ}$-nál (9. ábra: fekete négyzetekkel jelölve); ezek a az [111] és [200] reflexiók (JCPDS 76-1364), melyek a köbös rácsszerkezetü $\mathrm{ZnO}_{2}$-ra jellemzőek [111]. A (4) Scherrer-egyenletből számított primer részecskeméret $13 \mathrm{~nm}$-nek adódott.

A pormintát ezután 4 órás időtartamú hőkezelésnek vetettem alá, 200, 400, 600 és $800{ }^{\circ} \mathrm{C}$ hőmérsékleteken. A 9. ábrán látható diffraktogramokon a kalcinált minták esetében három csúcs van jelen, melyek a hexagonális $\mathrm{ZnO}$-ra jellemző [100], [002] és [101] reflexiók [112] (9. ábra: fekete körökkel jelölve). A hőmérséklet növelésével a vonalszélességek egyre csökkennek, ami az egyre kristályosabb ZnO fázis kialakulását jelzi. A ZnO fázis már $200{ }^{\circ} \mathrm{C}$ közelében kialakul $16 \mathrm{~nm}$-es primer részecskemérettel, melynek értéke a hőmérséklet emelkedésével $59 \mathrm{~nm}$-ig nő (1. táblázat). 


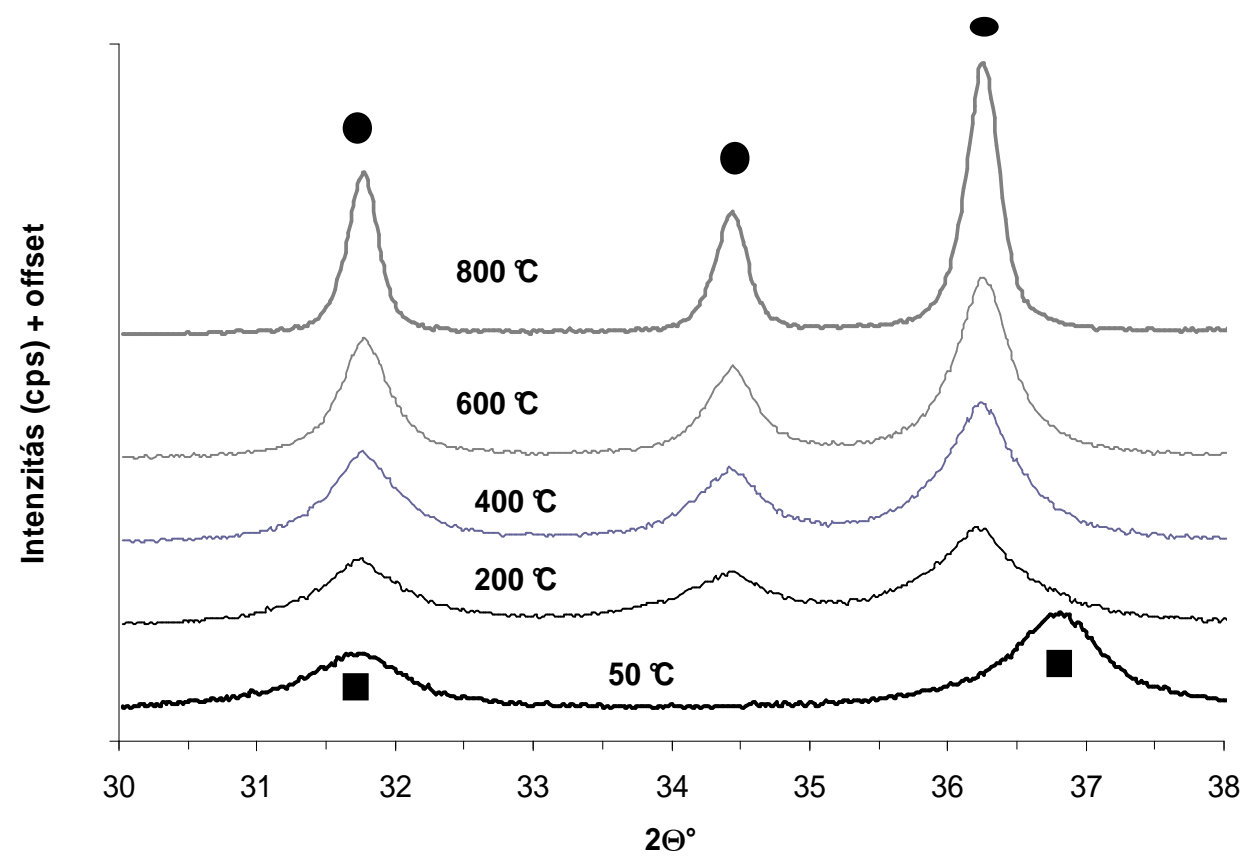

9. ábra A beszáritással $\left(50{ }^{\circ} \mathrm{C}\right)$ nyert cink-peroxid és a kalcinálással $\left(200-800{ }^{\circ} \mathrm{C}\right)$ kapott cink-oxid porminták röntgen diffraktogramjai

1. táblázat A primer részecskeméretek (Scherrer-egyenletből meghatározva) a kalcinálási hömérséklet függvényében

\begin{tabular}{cccccc}
\hline Hőmérséklet $\left({ }^{\circ} \mathbf{C}\right)$ & 50 & 200 & 400 & 600 & 800 \\
Részecskeméret $(\mathbf{n m})$ & 13.3 & 16.5 & 20.7 & 25 & 59 \\
\hline
\end{tabular}

\section{A cink-peroxid nanorészecskék vizsgálata dinamikus fényszórás méréssel (DLS)}

A cink-peroxid szol esetében DLS -sel meghatározott méreteloszlási görbe az 10. ábrán látható. A szolban a részecskék aggregált formában vannak jelen, ebből adódik, hogy a részecskék hidrodinamikai átmérője a dinamikus fényszórás mérésből 60-70 nm -nek adódik, ami jó egyezést mutat a transzmissziós elektron mikroszkópiai mérésekkel.

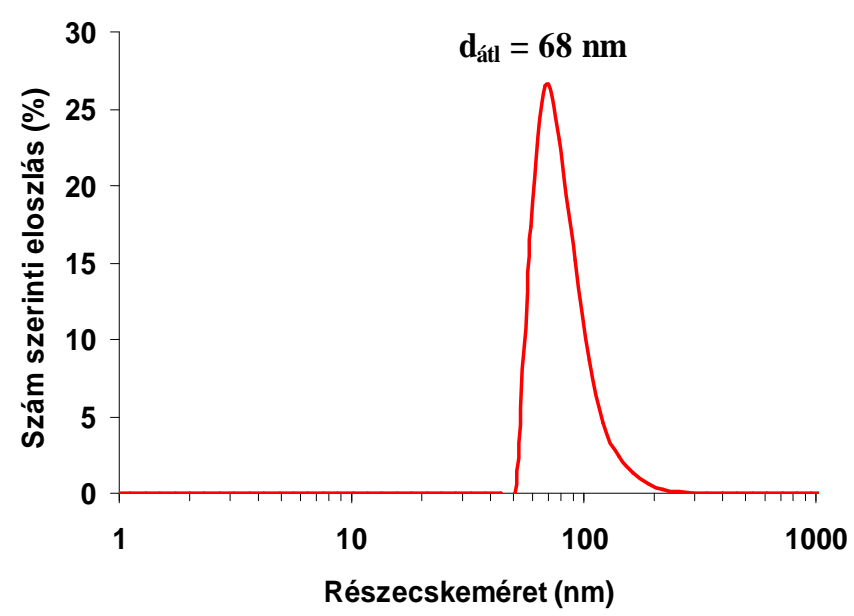

10. ábra $\mathrm{ZnO}_{2}$ szol részecskeméretének szám szerinti eloszlása 


\section{A cink-peroxid nanorészecskék termogravimetriás vizsgálata (TG, DTG)}

A termogravimetriás mérések segítségével pontosan megállapítható a $\mathrm{ZnO}_{2} \rightarrow \mathrm{ZnO}$ átalakulás pontos, szűk hőmérséklettartománya (11. ábra). A légszáraz $\mathrm{ZnO}_{2}$ minta termogravimetriás görbéje (11. ábra: TG) három jól elkülöníthető szakaszra bontható; az első, kb. $175{ }^{\circ} \mathrm{C}-$ ig a fiziszorbeált víz deszorpciójára jellemző, melynek anyagmennyisége 3-4 tömegszázalék (m\%). Ezt követi egy éles, határozott tömegveszteség, mely $213{ }^{\circ} \mathrm{C}$-nál a legjelentősebb, amint az az első derivált görbéböl (11. ábra: DTG) is leolvasható. Ez a cinkperoxid cink-oxiddá és oxigénné való bomlásának eredménye: a $175{ }^{\circ} \mathrm{C}$ és $250{ }^{\circ} \mathrm{C}$ közti tömegveszteség $16 \mathrm{~m} \%$, mely jól egyezik a $\mathrm{ZnO}_{2}(\mathrm{~s})=\mathrm{ZnO}(\mathrm{s})+1 / 2 \mathrm{O}_{2}(\mathrm{~g})$ reakció elméleti tömegmérlegével (16.4 m\%). A harmadik szakasz $\left(250{ }^{\circ} \mathrm{C}\right.$ felett) újabb 3-4 \%-os, csekélynek mondható tömegveszteséggel jár, mely nagy valószínűséggel az oxigén teljes eltávozásának, s egyben a végleges, tiszta $\mathrm{ZnO}$ fázis kialakulásának következménye, mely a röntgen diffrakciós mérésekkel is jó összhangban van.

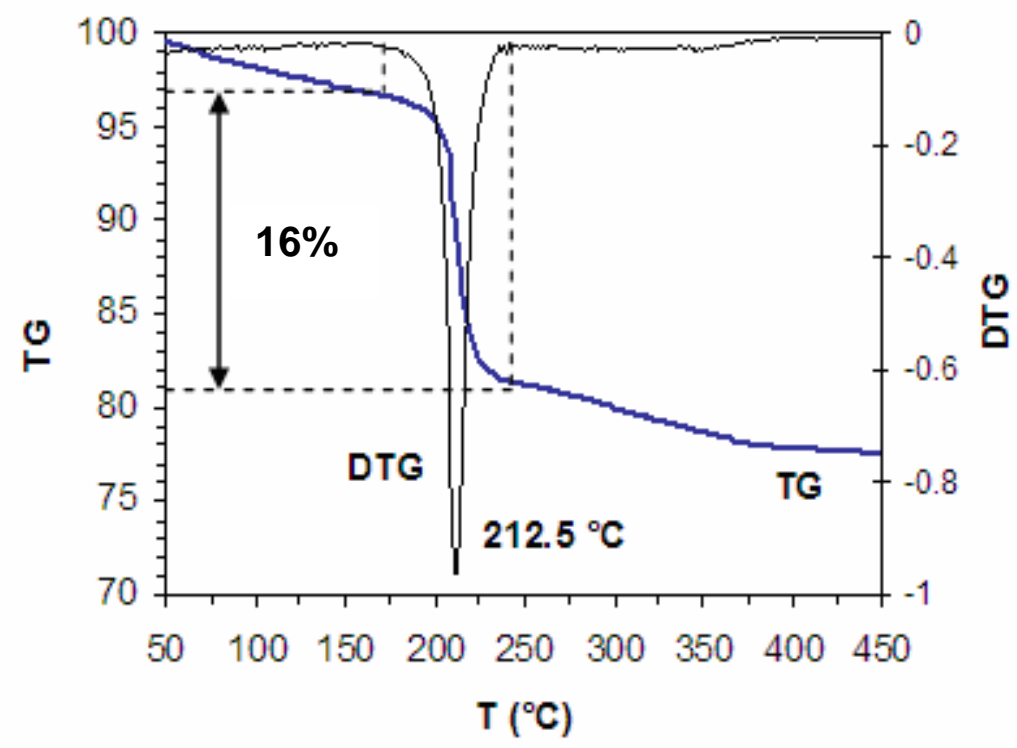

11. ábra Termoanalitikai mérések: A cink-peroxid minta TG és DTG görbéi

\section{A cink-peroxid részecskék vizsgálata transzmissziós elektron mikroszkópiával (TEM)}

A cink-peroxid részecskéket transzmissziós elektronmikroszkópiai mérésnek alávetve megállapíthatjuk, hogy a szolban kétféle föbb frakció van jelen. Egy ca. 20 nm-es átlagos átmérővel rendelkező kisebb, ill. kb. 60 nm-es átmérővel rendelkező nagyobb méretü frakció (12. ábra). Ez jó összhangban áll a (4) Scherrer-egyenletböl számolt értékkel (ca. $14 \mathrm{~nm}$ ) és a 
dinamikus fényszórás mérés eredményeivel $(50-70 \mathrm{~nm})$, hiszen a kisebb méretü frakció a primer részecskék csoportja, a nagyobb átmérőjü csoportot pedig az aggregátumok alkotják.

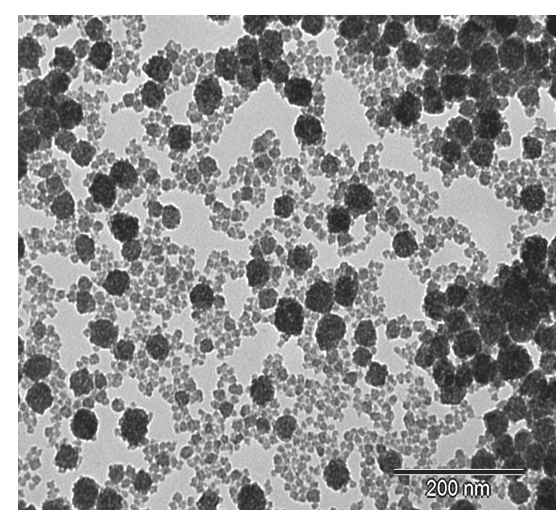

12. ábra $\mathrm{A} \mathrm{ZnO}_{2}$ részecskékröl készült TEM felvétel

\section{Felületi töltés ekvivalencia értékek meghatározása áramlási potenciál méréssel}

A vékonyrétegek építéséhez $0.85 \% \mathrm{ZnO}_{2}$ szol, $0.1 \%$ Na-hektorit szuszpenzió és $0.01 \%$ PSS oldatot használtam. A rétegalkotó komponensek koncentrációjának kiválasztásában döntő szerepet játszott a fajlagos felületi töltés meghatározása, melyhez áramlási potenciál mérést alkalmaztam annak érdekében, hogy a rétegek épüléséhez szükséges komponensek arányát optimalizálni tudjam. Ennek eredményei a következők: $0.0108 \mathrm{mmol}$ töltés /g $\mathrm{ZnO}_{2}$, 0.49 mmol töltés /g Na- Na-hektorit és 5 mmol töltés /g PSS. A kísérletileg meghatározott fajlagos töltések jó egyezést mutatnak az elméleti adatokkal (PSS: $4.85 \mathrm{mmol}$ töltés /g a monomer egység molekulatömegéböl meghatározva; Na-hektorit: $0.45 \mathrm{mmol}$ töltés /g ioncsere kapacitás).

Kísérleteim során azt tapasztaltam, hogy a $0.005 \%$ koncentrációjú PSS oldatból és $0.05 \%$ konc. Na-hektorit szuszpenzióból (1:10 töltésarány mellett) készített rétegek felépülése vagy nem egyenletes (az azonos hullámhosszakon mért abszorbancia értékek nem lineárisan növekednek a rétegszámmal), vagy pedig a kívánt rétegszám elött telítődött a rendszer, azaz megszünt az elektrosztatikus vonzóerő (a kötőanyag felől), amely szükséges a rétegek alternáló egymásra épüléséhez. A $0.05 \%$ koncentrációjú PSS oldatból és $0.02 \%$ konc. Na-hektorit szuszpenzióból (1:1 ill. 1:1.25 töltésarány mellett) készített rétegek esetében szintén az elektrosztatikus vonzás hiánya lépett fel túlzottan hamar (a cink-peroxid töltésének túlzott kompenzációja miatt), és/vagy a magas kötőanyag mennyiség miatt a rétegek rendezetlenül épültek, ezáltal átlátszatlanná váltak, erös fényszórással. $0.01 \%$ PSS oldatból ill. $0.1 \%$ Na-hektorit szuszpenzióból (1:5 töltésarány mellett) a rétegek egyenletesen, rendezetten, lineáris abszorbancia növekedéssel épültek, így megállapítottam, hogy az 
optimális töltésarány a cink-peroxid és a kötőanyag közt 1:5, munkám során ezért mindvégig ezt az arányt, azaz $0.85 \%(\mathrm{~g} / \mathrm{L})$ koncentrációjú $\mathrm{ZnO}_{2}$ szolt, $0.1 \%$ Na-hektorit szuszpenziót és $0.01 \%$ PSS oldatot használtam a vékonyrétegek építéséhez.

2. táblázat Töltésarányok $\mathrm{ZnO}_{2} / \mathrm{PSS}$ és $\mathrm{ZnO}_{2} / \mathrm{Na}$-hektorit rendszerek esetében, különbözö kötöanyag arányok mellett

\begin{tabular}{ccccccccc}
\hline & $\mathrm{ZnO}_{2}$ & \multicolumn{3}{c}{ PSS } & \multicolumn{4}{c}{ Na-hektorit } \\
\hline Töltés (mmol töltés / $\mathbf{g})$ & 0.0108 & & 5 & & & 0.49 & \\
Koncentráció $(\%)$ & 0.85 & 0.005 & $\mathbf{0 . 0 1}$ & 0.05 & 0.05 & $\mathbf{0 . 1}$ & 0.2 \\
Töltésarány $\left(\mathrm{ZnO}_{2}: \mathbf{X}\right)$ & - & $1: 10$ & $\mathbf{1 : 5}$ & $1: 1$ & $1: 10$ & $\mathbf{1 : 5}$ & $1: 2.5$ \\
\hline
\end{tabular}

\subsection{Pórusos önrendeződő vékonyrétegek optikai tulajdonságainak meghatározására szolgáló módszer bemutatása}

A d=30-3000 $\mathrm{nm}$ tartományba eső rétegvastagságú vékonyrétegek optikai tulajdonságai fehér fény segítségével meghatározhatóak, ugyanis ebben a tartományban a széles spektrumú (,fehér fényü”) fényforrások kis koherencia hosszúságú (2-3 $\mu$ m) sugarai is képesek interferencia-jelenségeket produkálni. Az interferenciával terhelt, ezáltal szélsőértékekkel (minimumokkal és maximumokkal) rendelkező transzmisszió ill. reflexió spektrumok információt hordoznak az optikai tulajdonságokat illetően. Ahhoz, hogy a meghatározni kívánt mennyiségeket (rétegvastagság, törésmutató) meghatározzuk, három modellre van szükségünk:

\section{SZILÁRDTEST MODELL (geometriai modell)}

A szilárdtest modell tartalmazza a vékonyréteget felépítő anyagok fizikai, kémiai tulajdonságait, állandóit, valamint, hogy milyen geometria és orientáció szerint véljük az egységeket egymáshoz képest elhelyezkedni. Számításaimhoz a következő modellt alkottam meg (13.a ábra):

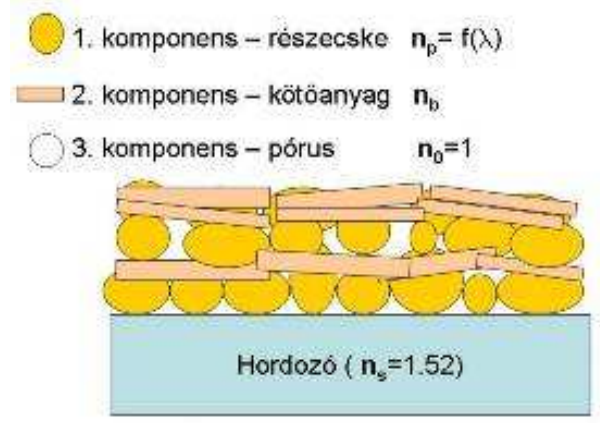

13.a ábra A számoláshoz használt szilárdtest modell 
A modellben három komponenst vettem figyelembe:

- egy hullámhossz-függő törésmutatóval rendelkező szilárd komponenst (részecskét), melynek $\mathrm{n}_{\mathrm{p}}(\lambda)$ refrakciós indexét szakirodalomban fellelhető információkból rekonstruáltam $A$ és $B$ Cauchy-együtthatók segítségével:

$$
n(\lambda)=A+\frac{B}{\lambda^{2}}
$$

ahol $\lambda$ a hullámhossz; a $\mathrm{ZnO}_{2}$ törésmutatója 1.76-1.91, a $\mathrm{ZnO}$ törésmutatója pedig $1.98-2.07[7]$.

- egy konstans törésmutatójú szilárd alkotót (a kötőanyag), ennek - látható tartományban kismértékü - diszperzióját elhanyagoltam ( $\mathrm{n}_{\mathrm{b}}=$ konst., $\mathrm{n}_{\text {PSS: }}$ 1.395, $\left.\mathrm{n}_{\text {Optigel }}: 1.503\right)$;

- konstans törésmutatóval rendelkező pórusokat, melyek értéke a levegő törésmutatója $\left(\mathrm{n}_{0}=1.000293\right)$

- a hordozó törésmutatóját a gyártó honlapjáról olvastam le, értéke $\mathrm{n}_{\mathrm{s}}=1.513-1.523$

( $\lambda=546.07 \mathrm{~nm}$ és $\lambda=643.85 \mathrm{~nm}$ között $), \mathrm{n}_{\text {átlag }}=1.518$ értéket használtam;

\section{EFFEKTÍV KÖZEG MODELL (szilárdtest/pórus átlagolás)}

Az effektív közeg modell határozza meg azt, hogy milyen megfontolások és egyenletek alapján kívánjuk homogenizálni a vékonyrétegünket, mely a legegyszerübb esetben is két szilárd komponensből és pórusokból áll, valamint felületi érdességgel rendelkezik. Ennek eredményeképp kapunk egy állandó rétegvastagsággal és homogén törésmutatóval rendelkező rendszert (13.b ábra).

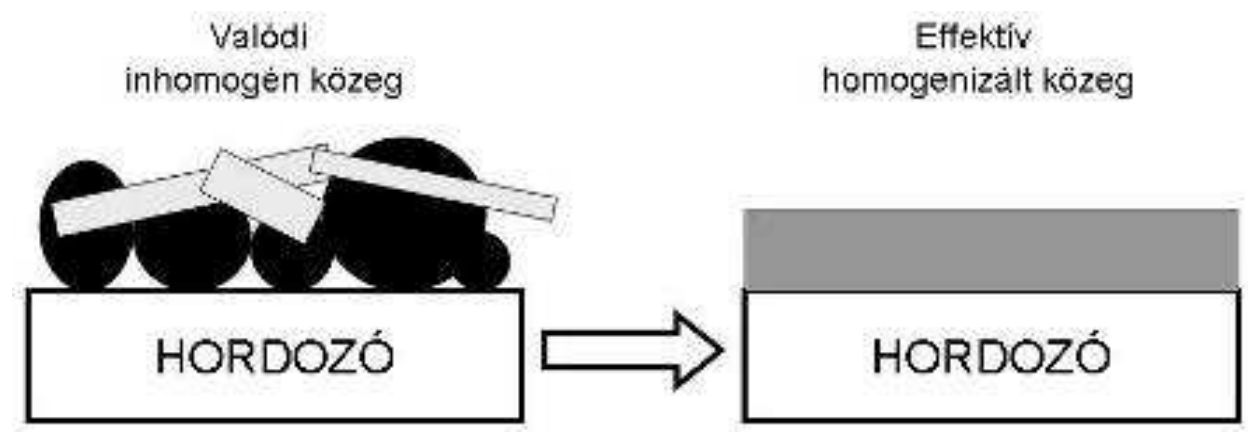

13.b ábra A valódi és a homogenizált (effektív) közeg sematikus összehasonlítása

Az irodalomban számos fellelhető modell közül a három komponensre kiterjesztett Bruggeman-féle effektív közeg közelítést választottam. Ez az egyik legelterjedtebb 
modell, másfelől a számítógépes kiértékelő programba is könnyen beépíthetőnek bizonyult. A felhasznált egyenlet:

$$
o \cdot \frac{n_{0}{ }^{2}-n_{e}{ }^{2}}{n_{0}{ }^{2}+2 n_{e}{ }^{2}}+p \cdot \frac{n_{p}{ }^{2}-n_{e}{ }^{2}}{n_{p}{ }^{2}+2 n_{e}{ }^{2}}+b \cdot \frac{n_{b}{ }^{2}-n_{e}{ }^{2}}{n_{b}{ }^{2}+2 n_{e}{ }^{2}}=0
$$

ahol $o$ a pórusok, $p$ a részecske, $b$ a kötőanyag térfogattörtje és $o+p+b=1$, valamint $n_{0}$ a pórusok, $n_{p}$ a részecske, $n_{b}$ a kötőanyag és $n_{e}$ a homogenizált közeg törésmutatója, rendre.

\section{HULLÁMOPTIKAI MODELL (hullámterjedés)}

A hullámterjedési modell határozza meg, hogy levezetéseink során milyen, a hullámterjedésre, interferenciára vonatkozó egyenleteket, elméleteket használunk fel. $\mathrm{Az}$ immáron homogenizált rétegre vonatkozóan kétsugaras interferencia modellt alkalmaztam, azaz csak a réteg felületéről közvetlenül visszaverődő és a filmen keresztülhaladó, hordozó felületéről visszaverődő sugarakat összegeztem (14. ábra). A többi sugár elhanyagolása csak a reflektált fény intenzitásában okoz változást, a szélsőértékek helyében nem.

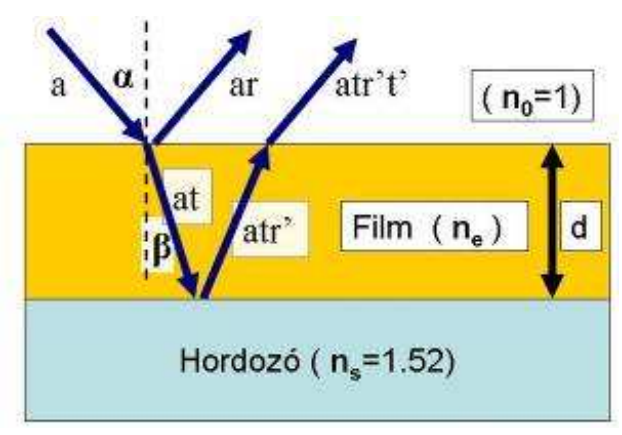

14. ábra A Bruggeman-féle effektív közeg közelítéssel homogenizált réteg és a vele kölcsönhatásba kerülö fénysugarak amplitúdóinak sematikus ábrázolása

A 14. ábrán feltüntetett, ar és atr't' amplitúdójú sugarak interferenciája következtében létrejövő intenzitást a komplex amplitúdók módszerével számítottam [113]:

Egy egyszerü harmonikus rezgőmozgás leírható

$$
y=a \cdot e^{i(\omega t-k x)}=a \cdot e^{-i \delta} \cdot e^{i \omega t}
$$

alakban, ahol $\omega$ a körfrekvencia, $k$ a hullámszám vektor $x$ irányú komponense, $a^{*} \exp (-i \delta)$ pedig az úgynevezett komplex amplitúdó. Azonos frekvenciájú hullámok összeadásánál az időfüggő tagnak nincs jelentősége, ezért két ilyen komponens összegzésekor az

$$
A \cdot e^{i \Theta}=a_{1} \cdot e^{i \delta_{1}}+a_{2} \cdot e^{-i \delta_{2}}
$$


komplex amplitúdók összegét számítjuk ki. Az intenzitás arányos az amplitúdó négyzetével, melyet úgy kapunk, hogy a komplex amplitúdók összegét megszorozzuk a komplex konjugáltjával:

$$
I_{R} \sim A^{2}=\left(A \cdot e^{i \Theta}\right) \cdot\left(A \cdot e^{-i \Theta}\right)
$$

A vékonyrétegről visszaverődő fény esetén a komplex amplitúdók összege a 14. ábra jelöléseit használva:

$$
A \cdot e^{i \Theta}=a \cdot r+a t r^{\prime} t^{\prime} \cdot e^{i \delta}
$$

ahol $a$ a beérkező sugár amplitúdója, $r$ a film felületének amplitúdó reflexiója, $t$ a ritkább közeg felőli áthaladás amplitúdó transzmissziója, $r$ ' a szubsztrát amplitúdó reflexiója, $t$ ' a sürübb közeg felőli áthaladás amplitúdó transzmissziója. Ezen konstansokra a következő összefüggések érvényesek:

$$
\begin{array}{r}
r=\left(\frac{n_{e}-n_{0}}{n_{e}+n_{0}}\right)^{2} \\
r^{\prime}=\left(\frac{n_{s}-n_{e}}{n_{s}+n_{e}}\right)^{2} \\
t=1-r \\
t^{\prime}=\frac{1-r^{2}}{t}
\end{array}
$$

(Megjegyzendő, hogy mivel $n_{0}=1<n_{e}<n_{s}=1.518$, ezért a közegek határán duplán lép fel fázisugrás, melyek eredője zéró, ezért az (12) egyenletben szereplő összeadás második tagjában nem szerepel $\exp (i \pi)$ fázisugrásból származó szorzótényező.

(12) egyenlet (11) -be írásával kapjuk, hogy

$$
I_{R} \simeq a^{2} \cdot\left[r^{2}+2 r r^{\prime}\left(1-r^{2}\right) \cos \delta+r^{\prime 2}\left(1-r^{2}\right)^{2}\right]
$$

ahol $\delta$ a két sugár közti fáziskülönbség, mely kifejezhető a sugarak közti optikai úthosszkülönbséggel:

$$
\delta=\frac{2 \pi}{\lambda} \Delta
$$

melyben $\Delta$ a sugarak közti optikai úthosszkülönbség, melyre a 14. ábra jelöléseit felhasználva a következő teljesül:

$$
\Delta=2 n_{e} d \cdot \cos (\beta)
$$


ahol $d$ a rétegvastagság, $\beta$ a törés szöge.

(17), (18) és (19) felhasználásával kapjuk végeredményül, hogy

$$
I_{R} \simeq a^{2} \cdot\left[r^{2}+r^{\prime 2}\left(1-r^{2}\right)^{2}+2 r r^{\prime}\left(1-r^{2}\right) \cos \left(\frac{4 \pi n_{e} d \cos \beta}{\lambda}\right)\right]
$$

A törésmutatókra, reflexiós és transzmissziós amplitúdókra vonatkozó egyenletek felhasználásával a (20) egyenlet alapján egy saját fejlesztésű szimulációs szoftverrel a legjobb illeszkedés alapján meghatározhatjuk a film rétegvastagságát és effektív törésmutatóját (15. ábra).
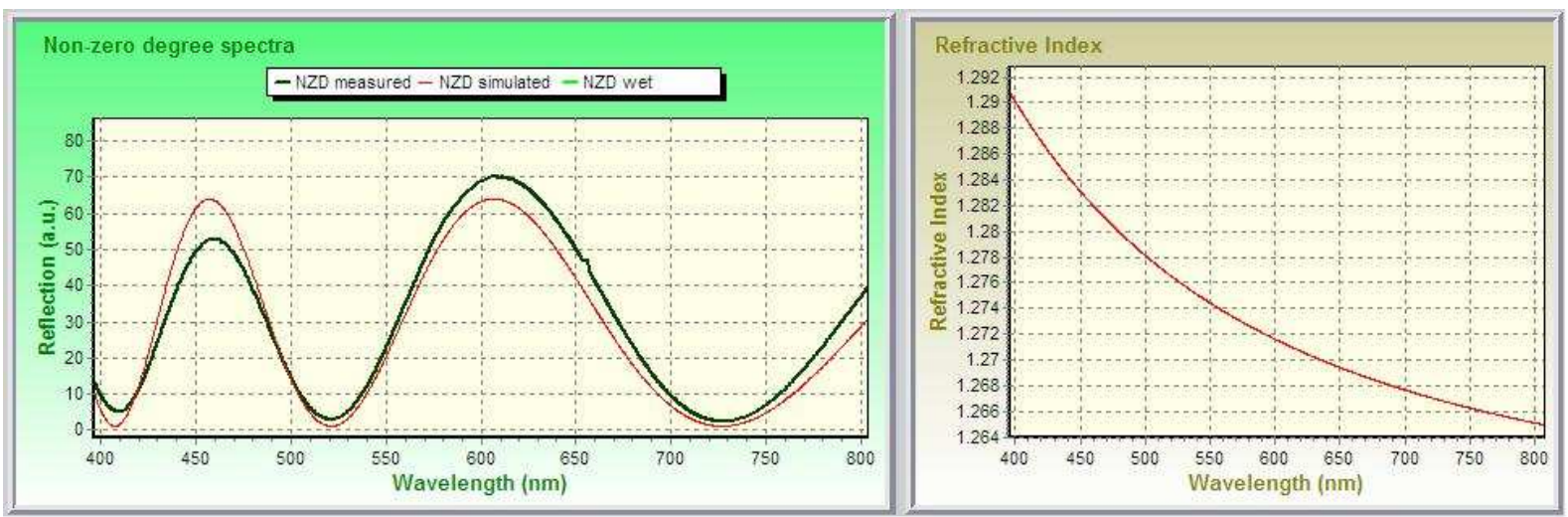

15. ábra A program képe müködés közben (képernyö fénykép)

(bal oldal: mért és illesztett nem-nulla fokos spektrum, jobb oldal: effektív törésmutató) 


\subsection{Cink-peroxid és cink-oxid tartalmú hibrid vékonyrétegek előállítása és vizsgálata}

A vékonyrétegeket a 3.2.1. pontban leírtak alapján, bemerítéses önrendeződő technikával készítettem el, üveg és szilícium hordozók felületén. Üveg esetében a hordozó mindkét oldalán van vékonyréteg, s átlátszósága miatt bővebb optikai vizsgálatra is lehetőség nyílik, viszont hátránya a néhány százaléknyi reflektált intenzitás.

Ezzel szemben a szilícium hordozó esetén a reflexió értéke egy nagyságrenddel magasabb (amely lehetővé teszi az interferencia-színek fényképezését), hátránya viszont, hogy nem átlátszó UV-látható fény számára, ezért abszorbancia mérés nem lehetséges, csak reflexió spektrumok felvétele.

\subsubsection{Szilícium hordozóra épített $\mathrm{ZnO}_{2} / \mathrm{PSS}$ és $\mathrm{ZnO}_{2} / \mathrm{Na}$-hektorit filmek (kvalitatív) vizsgálata - alapjelenségek bemutatása}

A $\mathrm{ZnO}_{2} / \mathrm{PSS}$ és $\mathrm{ZnO}_{2} / \mathrm{Na}$-hektorit rendszereket elsőként szilícium hordozón építettem fel. A rétegszám növekedésével egyre több interferencia szélsőérték (azaz interferencia rend) jelenik meg a spektrumon, ezzel követhetővé válik a filmépülés, abszorbancia mérés hiányában (16. ábra).

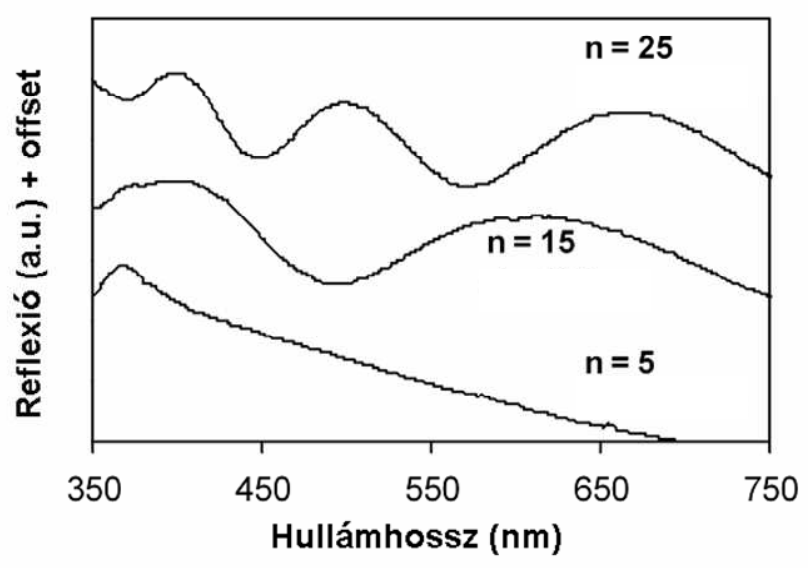

16. ábra 5, 15 és 25 réteges $\mathrm{ZnO}_{2} / P S S$ hibrid vékonyrétegek reflexió spektrumai

Azonban, a reflexió spektrumok nem csak a rétegvastagság növekedésével változnak, hanem egy adott rétegszám esetén a beesési szög növelésével is. Ez matematikailag a spektrumok eltolódását jelenti a kisebb hullámhosszak irányába (kék eltolódás, „,blue shift”), gyakorlatilag pedig szemmel észlelhető színváltozást jelent: azaz, a vékonyrétegek más-más 
irányból való szemlélése más-más színhatást eredményez. A 17.a és 17.b ábrákon a 30 réteges $\mathrm{ZnO}_{2} / \mathrm{PSS}$ és $\mathrm{ZnO}_{2} / \mathrm{Na}$-hektorit filmek szögfüggő reflexió spektrumait ábrázoltam.
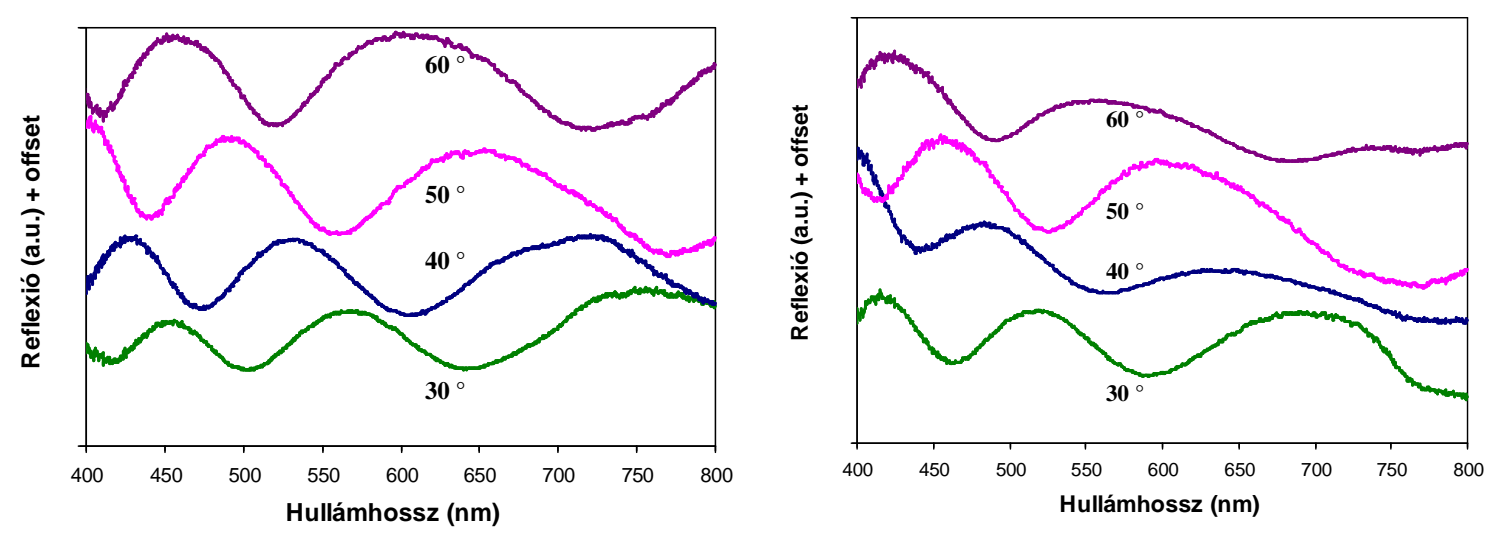

17. ábra 30 rétegszámú $\mathrm{ZnO}_{2} / \mathrm{PSS}$ (bal oldalon) és $\mathrm{ZnO}_{2} / \mathrm{Na}$-hektorit (jobb oldalon) hibrid vékonyréteg reflexió spektrumának szögfüggése

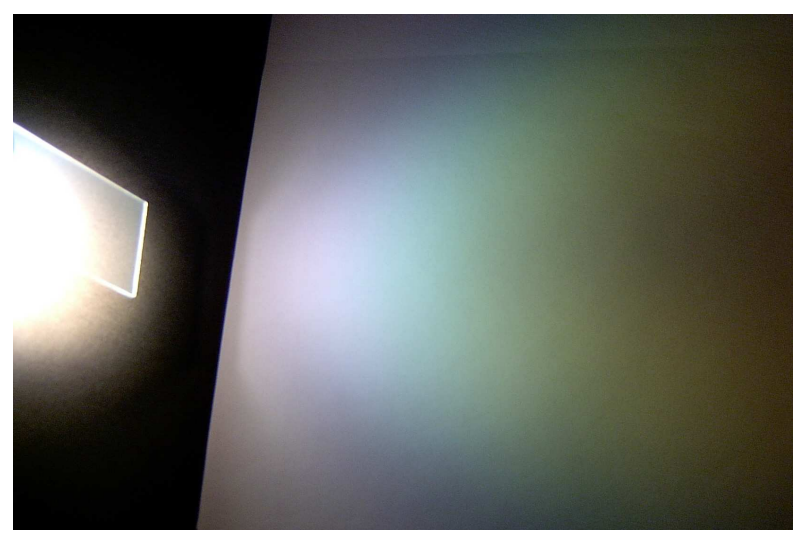

18. ábra Szilícium hordozóra épített 30 rétegszámú $\mathrm{ZnO}_{2} / \mathrm{PSS}$ hibrid vékonyrétegröl visszaverödö „interferencia-színek” -röl készült fénykép

\subsection{2. Üveg hordozóra épített $\mathrm{ZnO}_{2} /(P S S$ ill. Na-hektorit) és $\mathrm{ZnO} / \mathrm{Na}$-hektorit filmek vizsgálata}

\section{UV-látható elnyelés, optikai tulajdonságok}

Cink-peroxid/PSS, cink-peroxid/Na-hektorit és cink-oxid/Na-hektorit rendszereket előállítottam üveg hordozó felületén is. Ebből kifolyólag több részletre kiterjedő optikai vizsgálatokra volt lehetőség a hordozó UV-látható fény számára való átlátszósága miatt. A $\mathrm{ZnO}$ tartalmú filmeket $\mathrm{ZnO}_{2}$-ot tartalmazó vékonyrétegek 4 órán keresztüli, $400{ }^{\circ} \mathrm{C}$-os kalcinálásával nyertem. A polimer tartalmú filmek esetén erre azért nem volt lehetőség, mert a PSS már $150-200{ }^{\circ} \mathrm{C}$ hőmérsékleten termikus bomlást szenved. 
A 19.a és 19.b ábrákon láthatóak az ily módon elkészített $\mathrm{N}=5-20$ kettősrétegü $\mathrm{ZnO}_{2} / \mathrm{Na}$ hektorit és $\mathrm{N}=5-20$ kettősrétegü, $400{ }^{\circ} \mathrm{C}$-on kalcinált $\mathrm{ZnO} / \mathrm{Na}$-hektorit filmek abszorbancia spektrumai. A filmek elnyelése lineárisan és közel azonos mértékben nő $350 \mathrm{~nm}$ hullámhosszon, mely a jól orientált rétegszerkezet egyenletes felépülését jelzi.

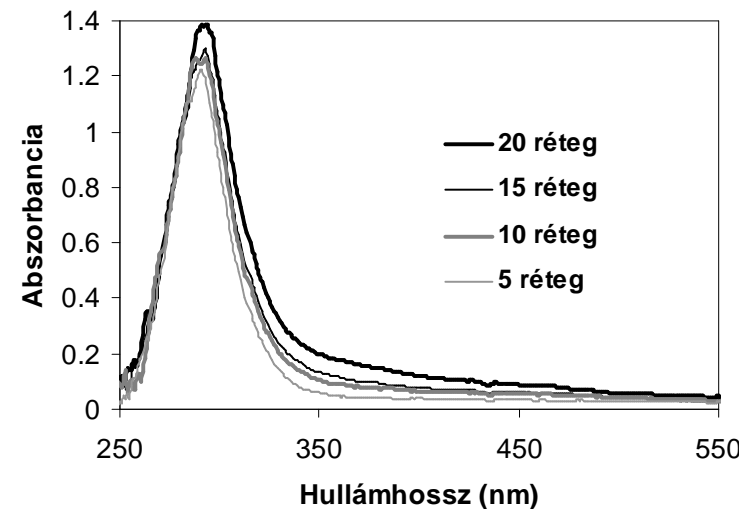

19.a ábra $5-20$ rétegszámú $\mathrm{ZnO} \mathrm{O}_{2} / \mathrm{Na}$ hektorit filmek abszorbancia spektrumai

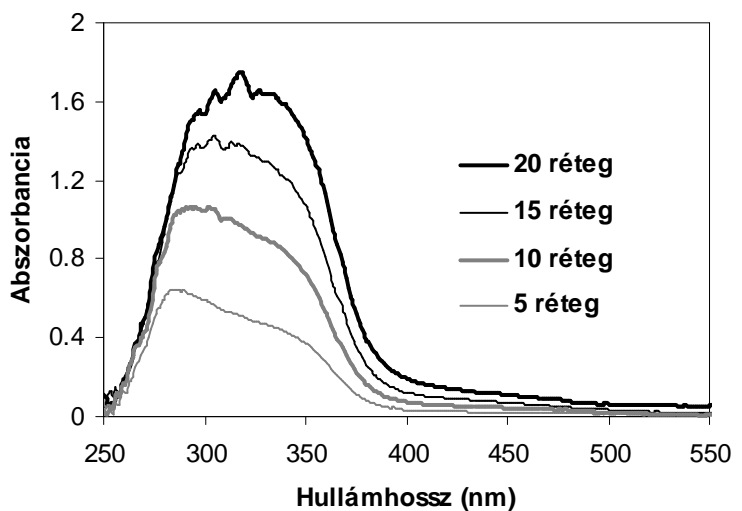

19.b ábra 5-20 rétegszámú $\mathrm{ZnO/Na-}$ hektorit filmek abszorbancia spektrumai

Mind jellegében, mind gerjesztési küszöbenergia értékeiben jelentős különbségeket tapasztalhatunk már felületes szemléléssel is a -peroxid és az -oxid formák között. A görbék kisebb hullámhosszak felőli felfutása szinte azonos, ám a ZnO tartalmú filmek abszorbancia spektrumainak félérték szélessége közel $50 \mathrm{~nm}$-rel nagyobb, ebből kifolyólag a gerjesztési küszöbenergia értéke is kisebb. $\mathrm{ZnO}_{2}$ tartalmú filmek esetében $\mathrm{E}_{\mathrm{g}}$ értéke a rétegszámtól függetlenül $3.98 \mathrm{eV}$ (a Na-hektorit kissé, de állandó mértékben növeli a cink-peroxid gerjesztési küszöbenergiáját $3.76 \mathrm{eV}$-ról $3.98 \mathrm{eV}$-ra, 20. ábra), a ZnO/Na-hektorit vékonyrétegek gerjesztési küszöbértéke pedig állandó $3.32 \mathrm{eV}$-ra csökken a kalcinálás során, a fázisátalakulás és anyagi minőség változás miatt.

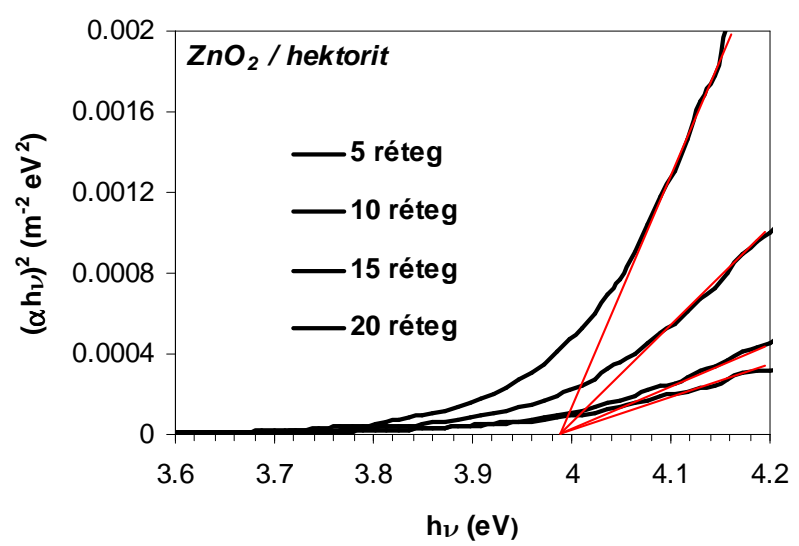

20. ábra 5-20 rétegszámú $\mathrm{ZnO}_{2} / \mathrm{Na}$-hektorit vékonyrétegek tiltott sáv energiáinak meghatározása Tauc-féle reprezentációval 
$\mathrm{A} \mathrm{ZnO}_{2} / \mathrm{PSS}$ rétegeket 30 kettősréteg számig építettem. A 21. ábrán láthatók az 5-30 rétegü cink-peroxid/PSS vékonyrétegek elnyelési spektrumai. A filmek felépülése ez esetben is egyenletesnek mondható, mert az abszorbancia közel lineárisan növekszik a rétegszámmal.

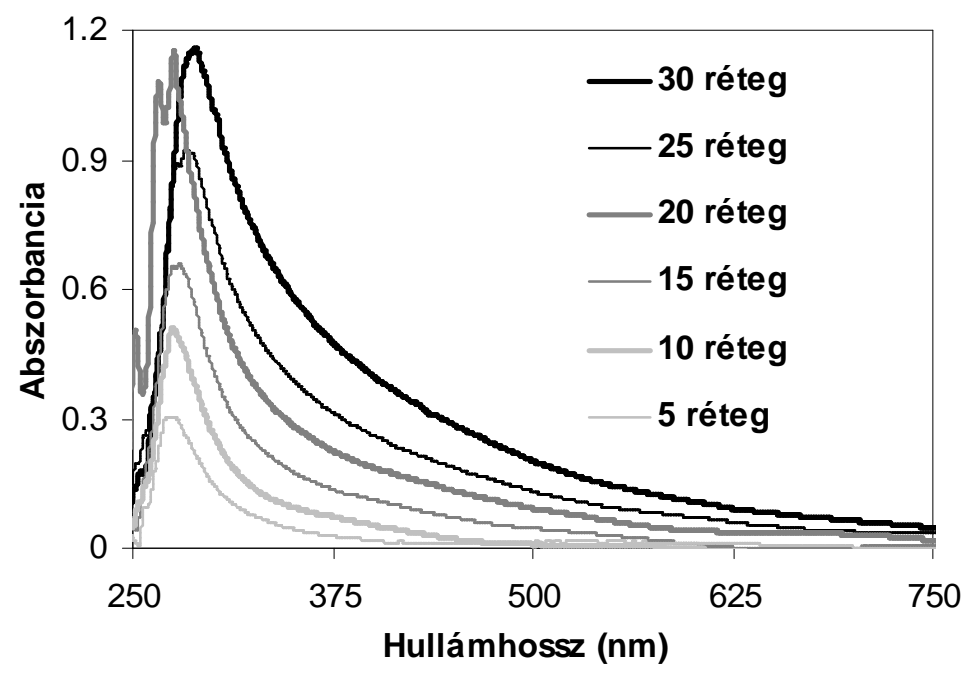

21. ábra 5-30 rétegü cink-peroxid/PSS nanofilmek abszorbancia spektrumai

A $\mathrm{ZnO}_{2} / \mathrm{PSS}$ vékonyrétegek esetén $\mathrm{E}_{\mathrm{g}}$ értéke változó, 4.12-3.74 eV (22. ábra, 3. táblázat). Nem csak a gerjesztési küszöbenergia elmozdulása, hanem az abszorbancia maximumhoz tartozó hullámhossz változása is csak a PSS -t tartalmazó filmekre jellemző, tehát a polielektrolit makromolekulák okozzák $E_{g}$ szisztematikus változtatását rétegszámtól függően.

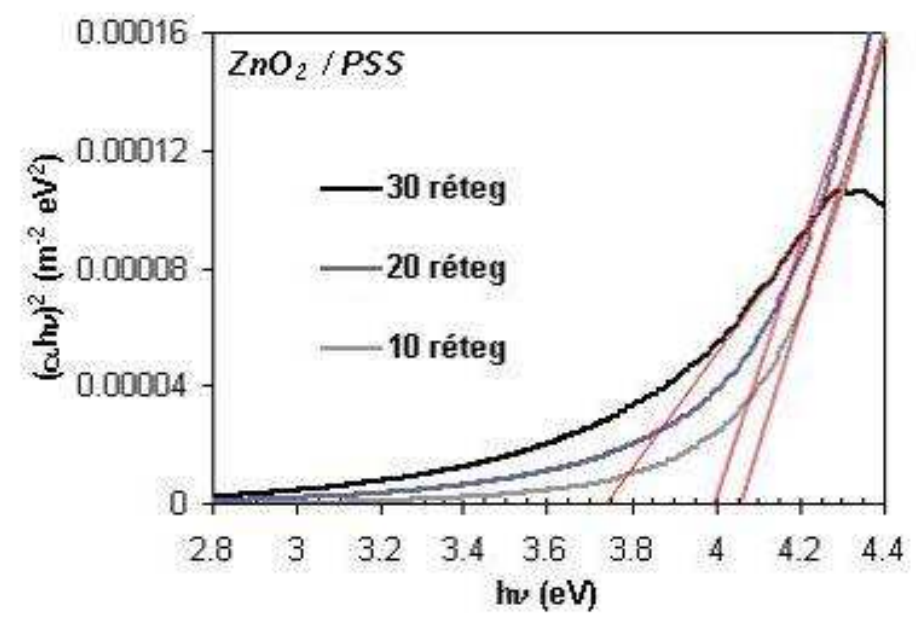

22. ábra 10,20 és 30 rétegszámú $\mathrm{ZnO}_{2} / \mathrm{PSS}$ vékonyrétegek bandgap energiáinak meghatározása Tauc-féle reprezentációval 
Megállapítottam, hogy a cink-peroxid/Na-hektorit vékonyrétegek esetében a tiltott sáv energiája független marad a rétegek számától, értéke állandó $3.98 \mathrm{eV}$, mivel a szilikát lamellák közt (ún. szabályozott térben) interkalálódott nanorészecskék mérete nem változik meg. Ez a tulajdonság kalcinálás után jellemző lesz a $\mathrm{ZnO} / \mathrm{Na}$-hektorit filmekre is, de értéke a szerkezet megváltozása miatt $3.2 \mathrm{eV}$-ra csökken. Ezzel szemben a PSS gombolyagok (kezdetben) jó hatásfokkal stabilizálják sztérikusan a nanorészecskéket, és ez által méret kvantált $\mathrm{ZnO}_{2}$ részecskékből álló rétegek képződnek a félvezetö/polielektrolit hibrid rétegekben, ezért a magas $E_{g}$ érték. A rétegszám növekedésével ez a hatás gyengül, legvégül az egész hibrid vékonyréteg egyetlen $\mathrm{ZnO}_{2}$ aggregátumként látszik a beeső fény számára, így megszűnik a méret kvantálási effektus.

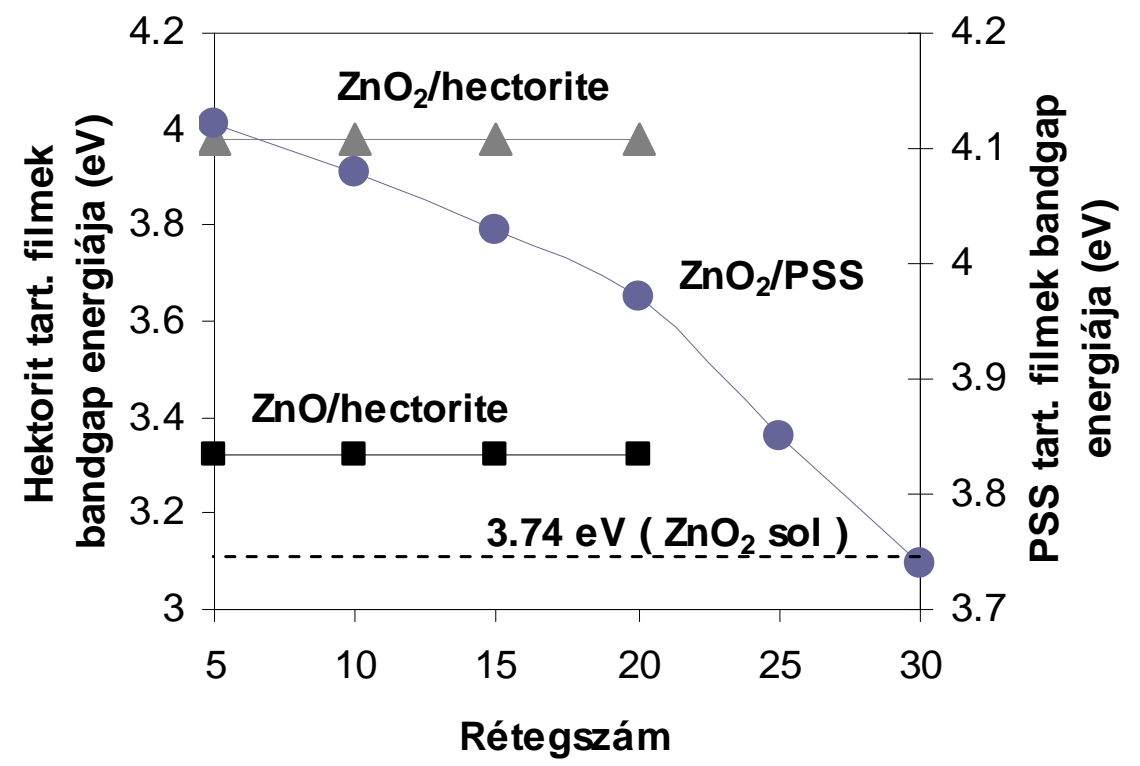

23. ábra $\mathrm{ZnO}_{2} / \mathrm{Na}$-hektorit, $\mathrm{ZnO} / \mathrm{Na}$-hektorit és $\mathrm{ZnO}_{2} / \mathrm{PSS}$ vékonyrétegek tiltott sáv energiáinak rétegszám függése

\section{A hibrid filmek szerkezetének elemzése röntgendiffrakcióval (XRD)}

A $\mathrm{ZnO}_{2}$ és $\mathrm{ZnO}$ tartalmú filmek szerkezetét XRD mérésekkel vizsgáltam. A 24. ábrán bemutatott diffraktogramok egyértelmüen bizonyítják a cink-peroxid és cink-oxid részecskék jelenlétét, bár az intenzitás a kis anyagmennyiség következtében meglehetősen kicsi. A $\mathrm{ZnO}_{2}$ köbös rácsára jellemző [111] és [200] reflexiók láthatók $2 \Theta^{\circ}=31.79^{\circ}$ és $36.87^{\circ}$-nál $(\mathrm{JCPDS}$ 76-1364). 4 órányi $400{ }^{\circ} \mathrm{C}$-os kalcinálás után a nagyobb szöghöz tartozó reflexió mintegy $0.6^{\circ}$-kal visszatolódik, valamint fenti szögtartományban megjelenik egy harmadik csúcs is. Ezek már a cink-oxid hexagonális cinkit struktúrájához tartozó reflexiók, nevezetesen [100], [002] és [101] s az ezekhez tartozó szögek $2 \Theta^{\circ}=31.77^{\circ}, 34.42^{\circ}$ és $36.25^{\circ}$, rendre 
(JCPDS 36-1451). Tehát megállapíthatjuk, hogy kalcinálás során a $\mathrm{ZnO}_{2}$ részecskék a filmekben $\mathrm{ZnO}$ részecskékké alakulnak át.

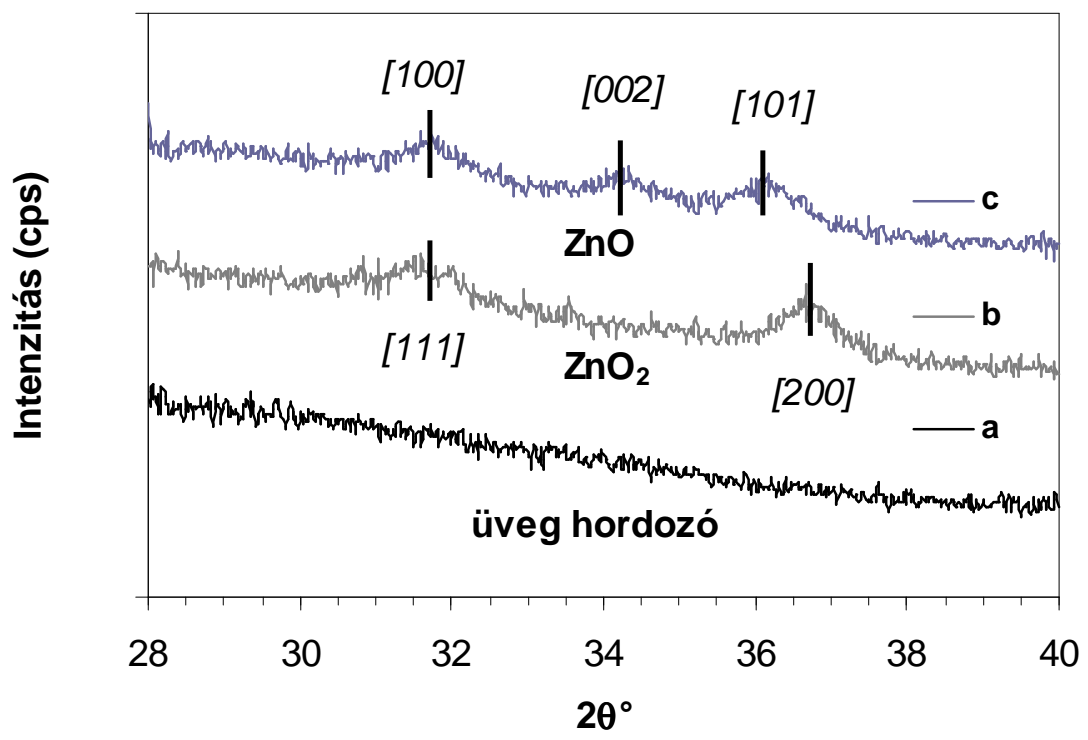

24. ábra $\mathrm{Az}$ üveg hordozó, a 20 réteges $\mathrm{ZnO}_{2} / \mathrm{Na}$-hektorit és a 20 réteges $\mathrm{ZnO} / \mathrm{Na}$ hektorit nanohibridek röntgen diffraktogramja

\section{A hibrid filmek szerkezetének elemzése atomerő mikroszkópiával (AFM)}

A nanofilmek felületi vizsgálatát atomerő mikroszkóppal (AFM) végeztem. A 25. ábrán, a bal oldali képen (fent) egy $\mathrm{N}=20$ rétegszámú $\mathrm{ZnO}_{2} / \mathrm{Na}$-hektorit vékonyrétegről készült felvétel látható, a jobb oldalon (fent) ugyanez a film $400{ }^{\circ} \mathrm{C}$-os kalcinálás után ( $\mathrm{ZnO} / \mathrm{Na}$-hektorit). Megállapíthatjuk, hogy kalcinálás, s ebből kifolyólag a fázisátalakulás hatására méretnövekedés és felületi durvulás következik be. $\mathrm{Az} \mathrm{N}=20$ rétegszámú $\mathrm{ZnO}_{2} / \mathrm{PSS}$ filmröl készült AFM felvételt (25. ábra, lent) tekintve megállapítottam, hogy az a $\mathrm{ZnO}_{2} / \mathrm{Na}$-hektorit réteggel mutat hasonlóságot, de azzal ellentétben nem jellemzőek a nagy méretü, durva aggregátumok, feltehetően a korábbiakban megállapított sztérikus stabilizáló hatásnak köszönhetően. 


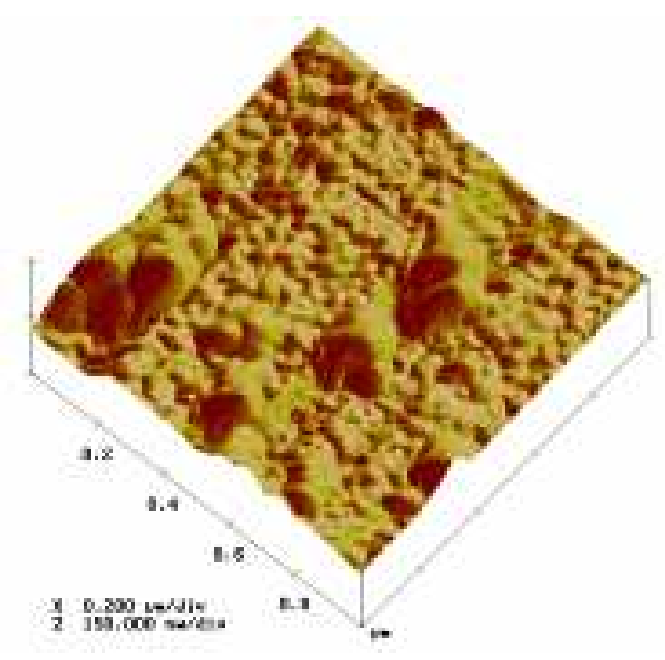

$\mathrm{ZnO}_{2} /$ Na-hektorit

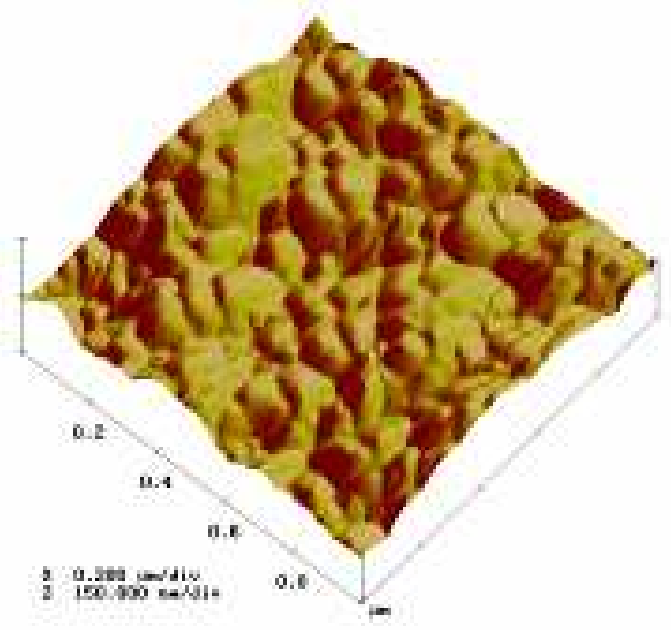

ZnO / Na-hektorit

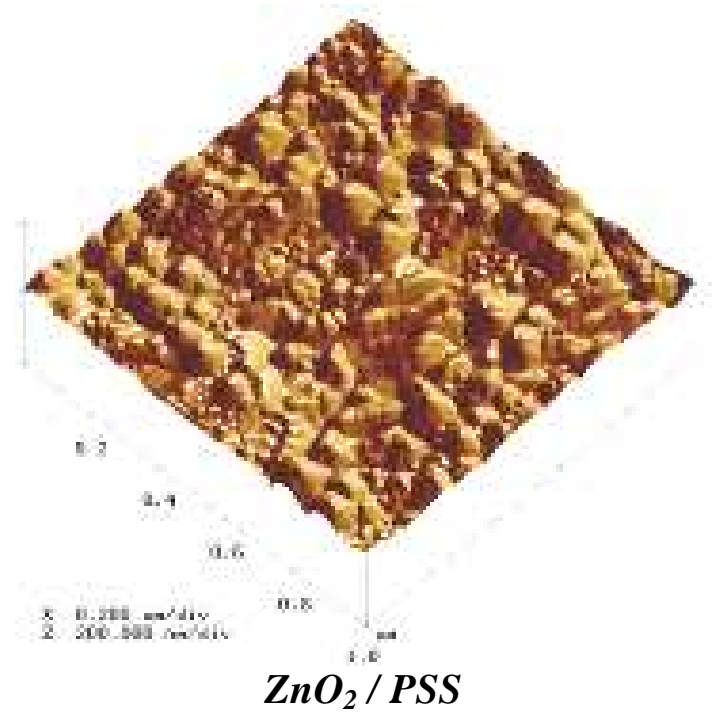

25. ábra 20 réteges $\mathrm{ZnO}_{2} / \mathrm{Na}$-hektorit, $\mathrm{ZnO} / \mathrm{Na}$-hektorit és $\mathrm{ZnO}_{2} / \mathrm{PSS}$ nanohibridek AFM felvételei

\section{A hibrid filmek reflexió spektrumainak vizsgálata}

Vizsgáltam az 5, 10, 15 és 20 kettősréteg számú $\mathrm{ZnO}_{2} / \mathrm{Na}$-hektorit és $\mathrm{ZnO} / \mathrm{Na}$-hektorit filmek reflexió spektrumait. Ennek célja a rétegvastagságok és a törésmutatók meghatározása volt. A 26. $a$ és $b$ ábrán láthatóak a mérési eredmények.

Az eredmények azt mutatják, hogy a kalcinálás során létrejövő $\mathrm{ZnO}_{2} \rightarrow \mathrm{ZnO}$ átalakulás eredményeképpen a filmek effektív törésmutatója megnő (27. ábra), rétegvastagsága pedig lecsökken (3. táblázat). Az effektív törésmutató növekedésének oka lehet, hogy a $\mathrm{ZnO}$ tömbfázisbeli törésmutatója (2.07-1.95) nagyobb,mint a cink peroxidé (1.91-1.76), valamint, hogy a hőkezelés hatására az anyag kristályosabb formába rendeződik, ezáltal tömörödik. Ezt a feltevést alátámasztja az is, hogy a rétegvastagság csökkenéséből következik a vékonyréteg sürüségének növekedése. 
A polielektrolit tartalmú filmek esetén kisebb törésmutatót mértem, melynek oka az, hogy a PSS törésmutatója kisebb, mint a Na-hektorité, valamint, hogy a sztérikus stabilizálás következtében lazább szerkezetű porózus rétegek jönnek létre.

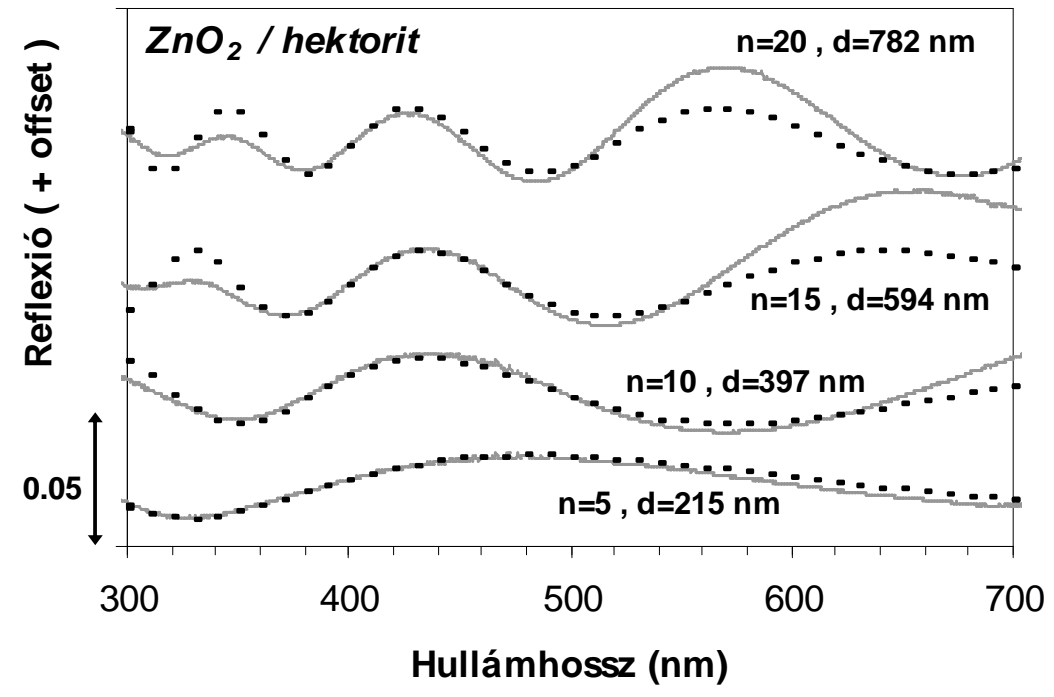

26.a ábra 5-20 rétegszámú cink-peroxid/Na-hektorit vékonyréteg mért (folytonos vonal) és számított (szaggatott vonal) reflexió spektrumai

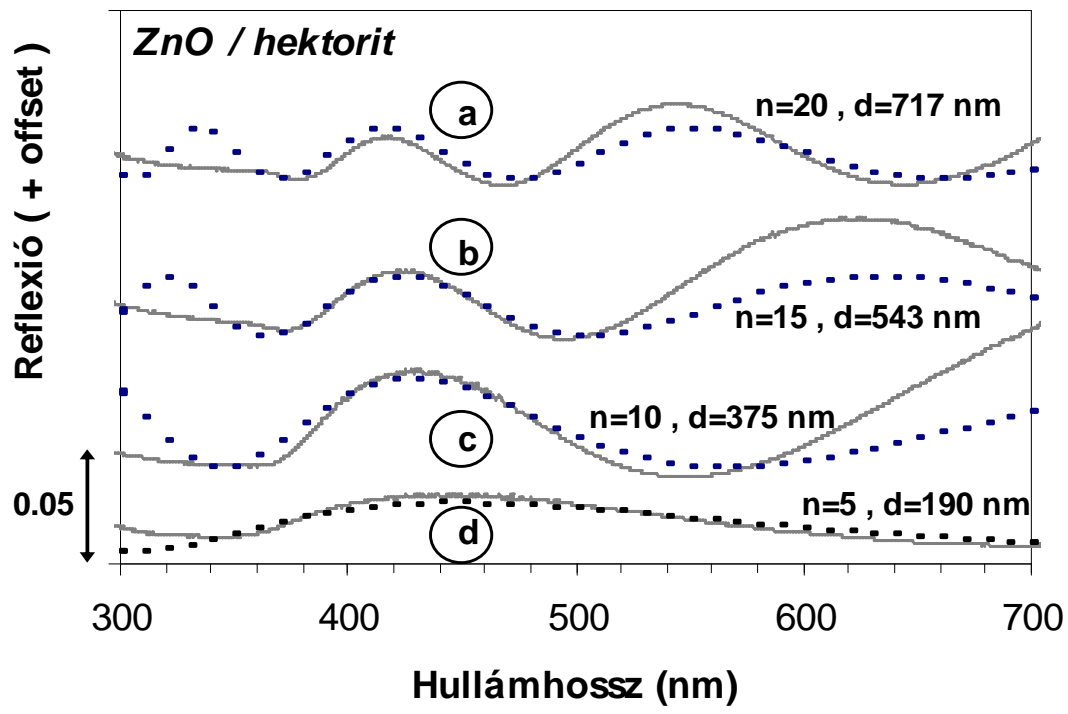

26.b ábra 5-20 rétegszámú cink-oxid/Na-hektorit vékonyréteg mért (folytonos vonal) és számított (szaggatott vonal) reflexió spektrumai 


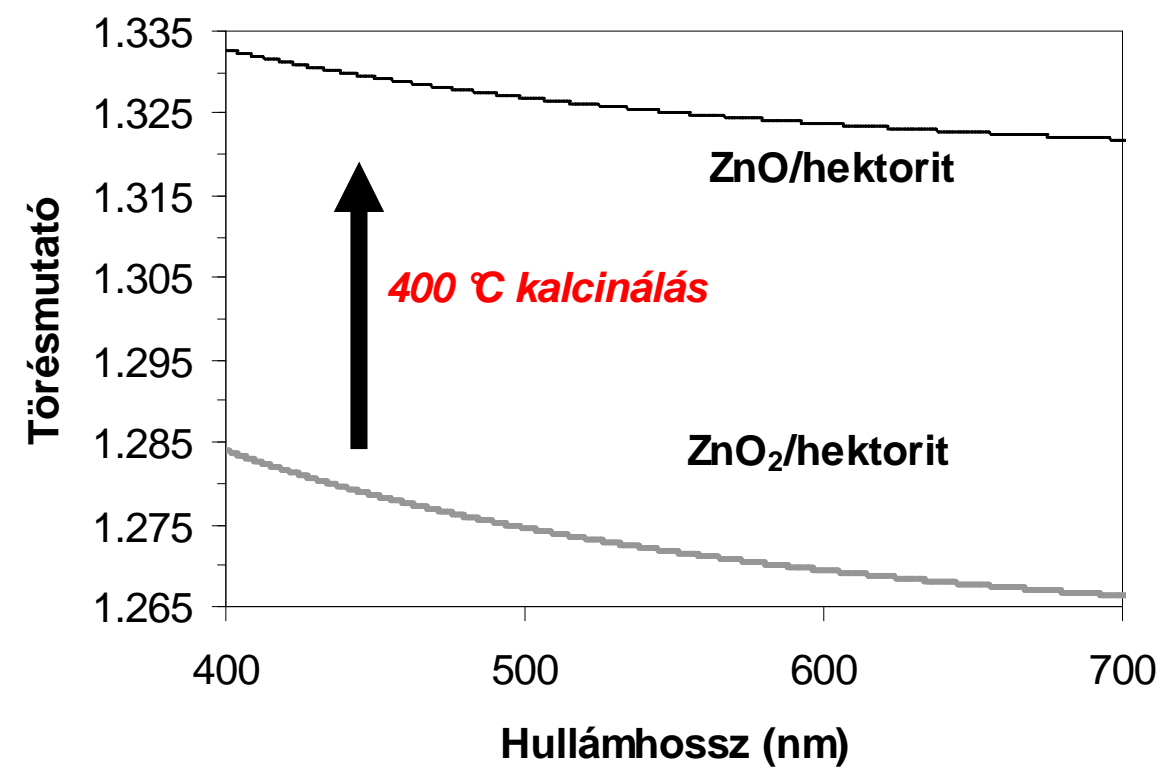

27. ábra A Na-hektorit tartalmú filmek törésmutatójának növekedése a kalcinálás hatására

3.táblázat $A$ vizsgált vékonyrétegek rétegvastagságai, törésmutatói és tiltott-sáv energiái

\begin{tabular}{|c|c|c|c|c|c|c|c|c|c|}
\hline & \multicolumn{4}{|c|}{ d (nm) } & \multirow{2}{*}{$\begin{array}{c}\text { n }(589 \mathrm{~nm}) \\
N=5-20\end{array}$} & \multicolumn{4}{|c|}{$\mathbf{E}_{\mathrm{g}}$} \\
\hline & $N=5$ & $N=10$ & $N=15$ & $N=20$ & & $N=5$ & $N=10$ & $N=15$ & $N=20$ \\
\hline $\begin{array}{l}\mathrm{ZnO}_{2} / \mathrm{Na}- \\
\text { hektorit }\end{array}$ & 215 & 397 & 594 & 782 & $1.269^{* *}$ & 3.98 & 3.98 & 3.98 & 3.98 \\
\hline $\begin{array}{l}\text { ZnO/Na- } \\
\text { hektorit }\end{array}$ & 190 & 375 & 543 & 717 & $1.324^{* * *}$ & 3.32 & 3.32 & 3.32 & 3.32 \\
\hline $\mathrm{ZnO}_{2} / \mathrm{PSS}$ & 162 & 315 & 482 & 650 & 1.248 & 4.12 & 4.08 & 4.03 & 3.97 \\
\hline
\end{tabular}

\subsection{3. $\mathrm{ZnO}_{2}$ /térhálós polimer hibrid vékonyrétegek üveg és arany bevonatú kvarckristály hordozón}

Cink-peroxid/térhálós polimer filmeket a 3.2.2. pont alapján állítottam elő. Az eljárás során kombináltam az önrendeződéses filmépítés és fénysugárzás hatására történő polimerizáció elemeit. Ezen rendszerek tanulmányozása azért került kutatásaim látóterébe, mert a korábban bemutatott vékonyrétegek nem bizonyultak kellőképpen szelektívnek. A PAAm és a PNIPAAm, mint hidrogélek a tömbi fázisú kísérletek során teljesen eltérően viselkednek: a PAAm hidrofil, míg a PNIPAAm túlnyomórészt hidrofób tulajdonságokat hordoz; előbbi a vizet, míg utóbbi az etilalkoholt és hosszabb szénláncú alkoholokat preferálja [114]. 
Kísérleteim során azt vizsgáltam, hogy ez a tendencia érvényesül-e, ha tömbi kiterjedés helyett vékonyrétegekben alkalmazzuk öket.

A térhálós polimer tartalmú filmek preparációja üveg és arany hordozón egyaránt történt; előbbi a filmek szerkezeti és optikai tulajdonságainak meghatározásához reflexió spektrumok mérésével, utóbbi a fajlagos tömeg megadásához kvarckristály mikromérleg (QCM) mérésekkel. A preparálás során 4 rendszert építettem fel: kettőt, melyek nem estek át polimerizációs eljáráson ( $\mathrm{ZnO}_{2} / \mathrm{NIPAAm}$ ill. AAm - referencia filmek), és kettő másikat, melyek nitrogén atmoszférában 1 perces UV besugárzással polimerizálódtak $\left(\mathrm{ZnO}_{2} / \mathrm{PNIPAAm}\right.$ ill. PAAm - polimer filmek). Ezt abból a célból tettem, hogy felderítsem, miként befolyásolja a monomerek térhálós polimerré alakulása a filmek épülését és a későbbiekben az adszorpciós tulajdonságokat.

\section{Röntgendiffrakciós (XRD) és Fourier-transzformációs infravörös spektroszkópia (FTIR)} vizsgálatok

$\mathrm{Az}$ elkészült vékonyrétegeket röntgen diffrakciós és infravörös spektroszkópia módszerekkel vizsgáltam: a $\mathrm{ZnO}_{2}$ jelenlétét $\mathrm{XRD}$ mérésekkel igazoltam mind üveg, mind arany hordozó felületén (28. ábra, [111] és [200] csúcsok), a polimerizáció bekövetkezését pedig FTIR mérésekkel támasztottam alá (29. ábra). A monomerekre jellemző telítetlen kötések $\left(1600 \mathrm{~cm}^{-1}\right.$-nél) eltűnnek vagy intenzitásuk jelentősen csökken, és a polimerekre jellemző -CH- kötések megjelennek (1300 cm-1 hullámszám környékén), mely a polimerizáció bekövetkezését támasztja alá.

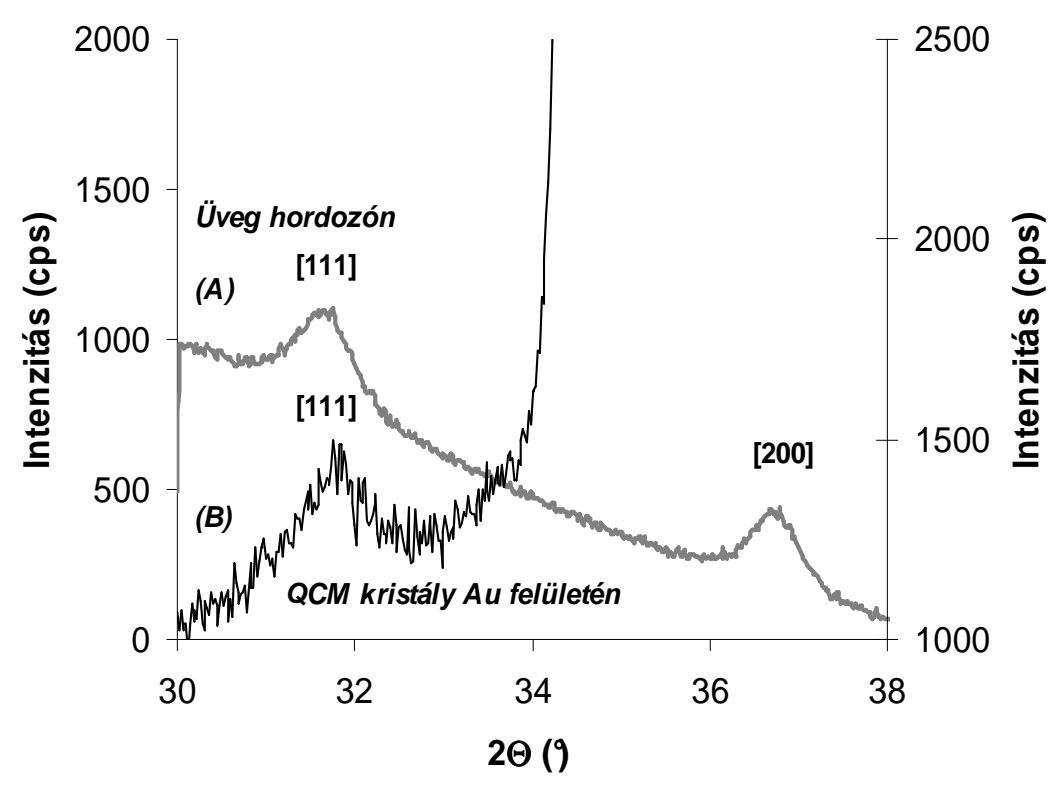

28. ábra 12 rétegszámú cink-peroxid/polimer hibrid film röntgen diffraktogramja 


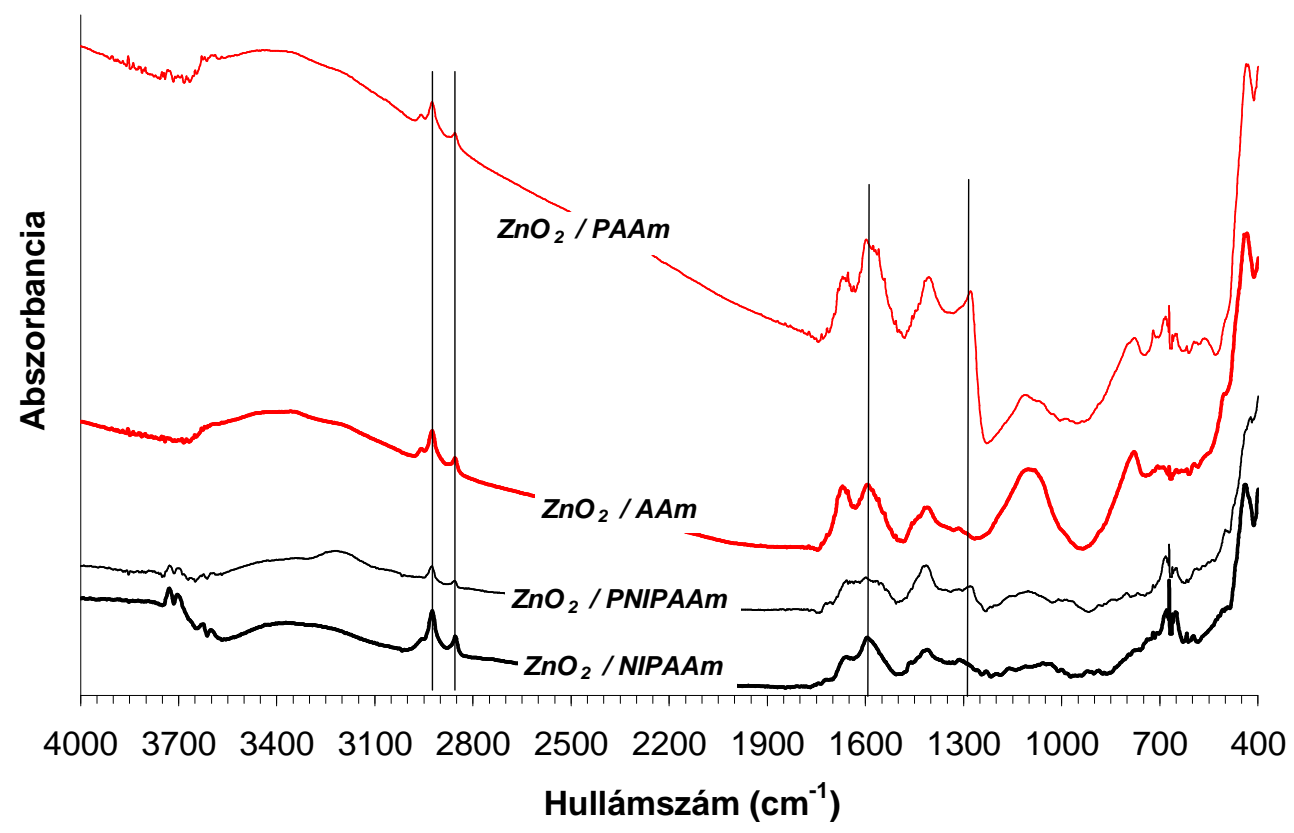

29. ábra 12 rétegszámú cink-peroxid/polimer hibrid vékonyrétegek FTIR spektruma

A cink-peroxid/térhálós polimer vékonyrétegek törésmutatójának, rétegvastagságának és fajlagos tömegének meghatározása reflexió spektrumok vizsgálatával és QCM-mel

Vizsgáltam a $\mathrm{ZnO}_{2}$ /polimer hibrid vékonyrétegek reflexió spektrumait a 6 . ábrán bemutatott elrendezéssel. Ennek eredménye a 30.a és 30.b ábrákon látható.

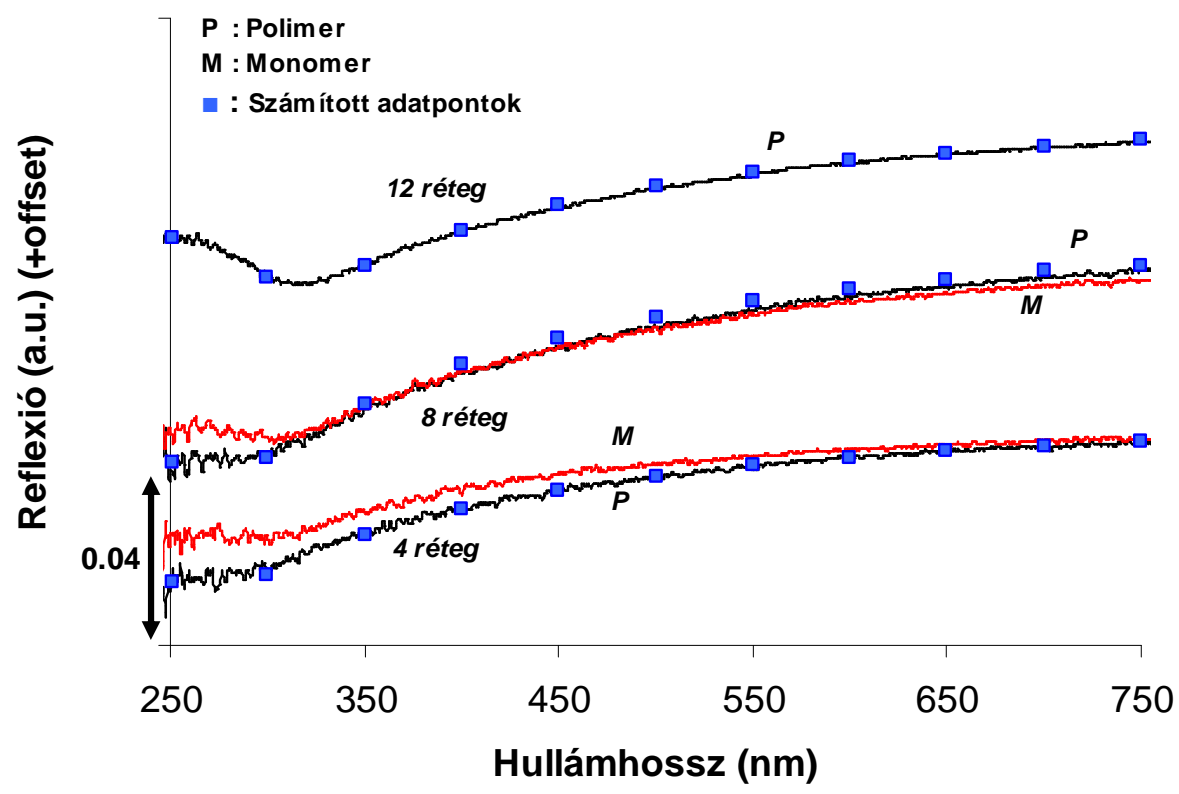

30.a ábra 4, 8 és 12 rétegü cink-peroxid/NIPAAm $(M)$ ill. cink-peroxid/PNIPAAm (P) filmek mért (folytonos vonal) és számított (pontok) reflexió spektrumai 


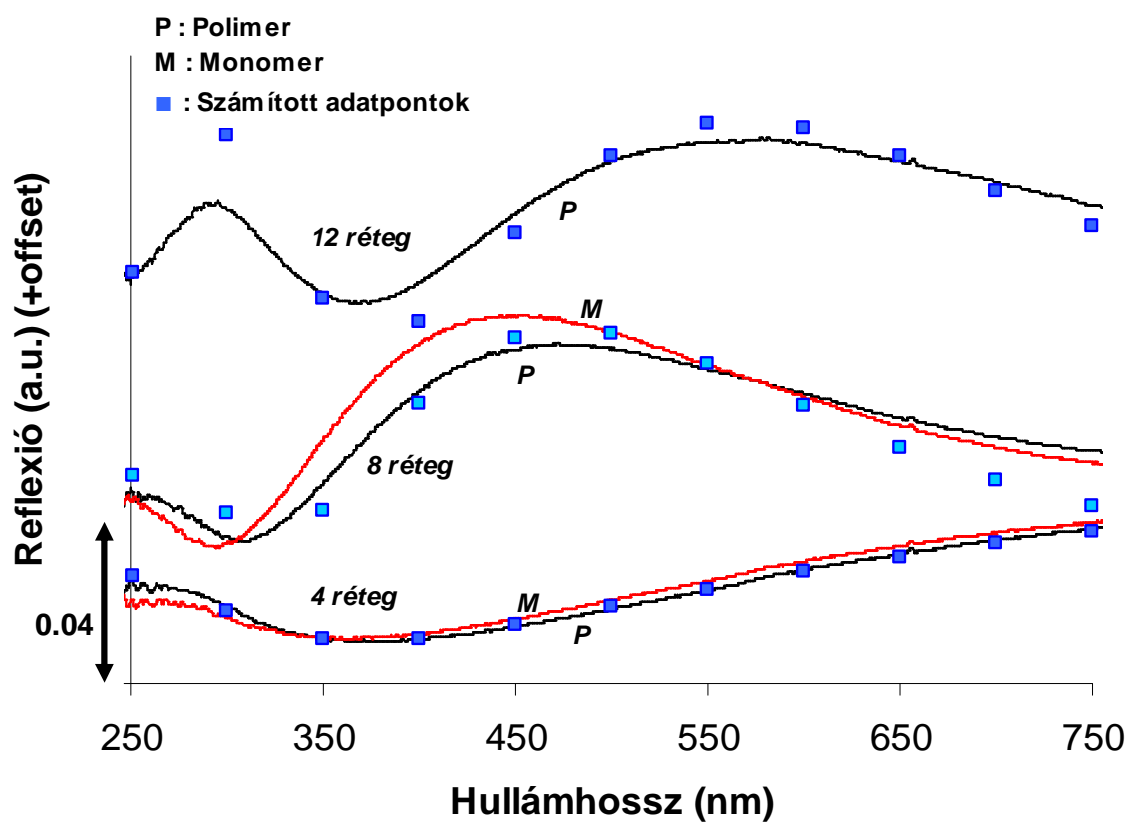

30.b ábra 4, 8 és 12 rétegü cink-peroxid/AAm $(M)$ ill. cink-peroxid/PAAm $(P)$ filmek mért (folytonos vonal) és számított (pontok) reflexió spektrumai

Az ábrákból kitünik, hogy a polimerizáció a rétegvastagság értékét csekély mértékben befolyásolja, ezt a tényt támasztja alá a 31. ábra is, melyen a rétegvastagságokat ábrázoltam a rétegszám függvényében. A NIPAAm alapú filmek vastagsága közel harmad akkora, mint az AAm alapú filmeké. Ez feltehetően a gyengébb elektrosztatikus kölcsönhatás eredménye. A rétegvastagság meghatározásával egy időben a törésmutatót is meghatároztam (32.ábra).

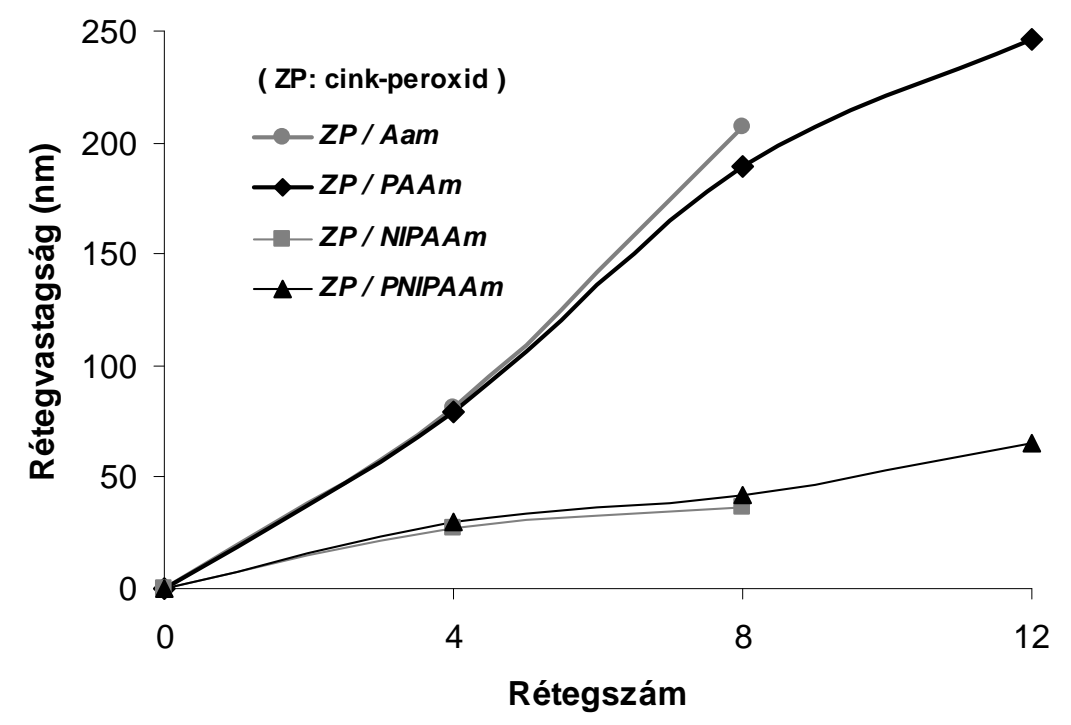

31. ábra A monomer (referencia) és a polimer filmek rétegvastagsága a rétegszám függvényében 


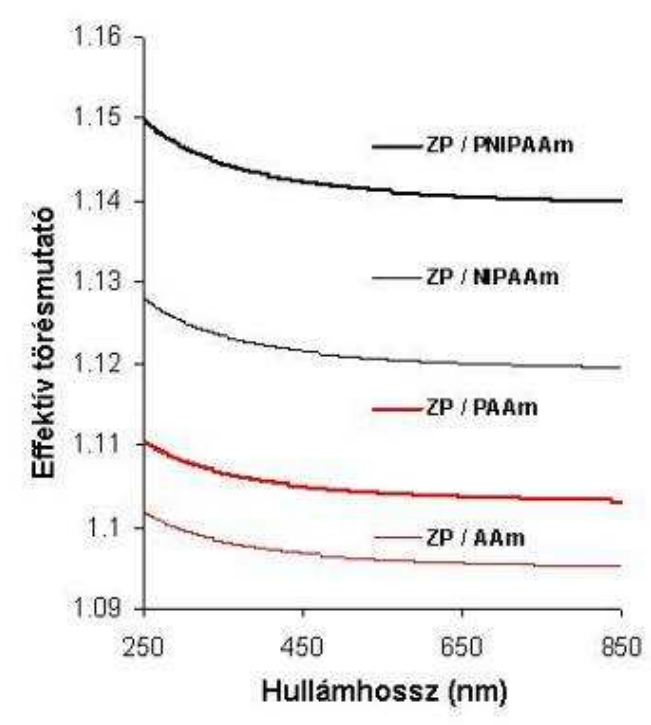

32. ábra Az 12 kettösréteg számú hibrid filmek effektív törésmutatója

A filmek felépülését követtem QCM mérésekkel is, valamint ezeket a filmeket használtam később adszorpció mérésére. A NIPAAm tartalmú filmek esetében mért tömegnövekedés (kb. $1 \mu \mathrm{g} / \mathrm{cm}^{2} /$ réteg) háromszor kisebb, mint az AAm filmek esetében (kb. $3 \mu \mathrm{g} / \mathrm{cm}^{2} /$ réteg), így azt mondhatjuk, hogy az eredményeink jó összhangban állnak az optikai mérésekkel (33. ábra). A vékonyrétegek fontosabb fizikai állandóit az 4. táblázat tartalmazza.

$$
\begin{aligned}
& \rho=x_{s} \rho_{s}+x_{a} \rho_{a}+x_{p} \rho_{p} \\
& n_{e f f}=x_{s} n_{s}+x_{a} n_{a}+x_{p} n_{p} \\
& \varepsilon=1-\frac{V_{s}}{V_{s}+V_{a}+V_{p}}
\end{aligned}
$$

ahol $x_{s}, x_{a}$ és $x_{p}$ az egyes komponensek térfogattörtje, $\rho_{s}, \rho_{a}$ és $\rho_{p}$ a sürüségek, $n_{s}, n_{a}$ és $n_{p}$ a $\mathrm{ZnO}_{2}$, pórus (levegő) és a polimer törésmutatója, $V_{s}$ és $V_{a}$ a $\mathrm{ZnO}_{2}$ és levegő térfogata, rendre. A NIPAAm tartalmú filmek törésmutatója magasabb, mint az AAm tartalmúaké, mely összhangban áll a rétegvastagsággal kapcsolatban megállapítottakkal, hiszen ezek kompaktabb, tömörebb rendszerek lehetnek. Az is megállapítható, hogy a polimerizálódott filmeknek ugyancsak magasabb az effektív törésmutatója, mint polimerizálatlan párjaiknak. Feltehetően a polimerizáció következtében a térháló kissé összehúzza a részecskéket, egymáshoz közelebb. 


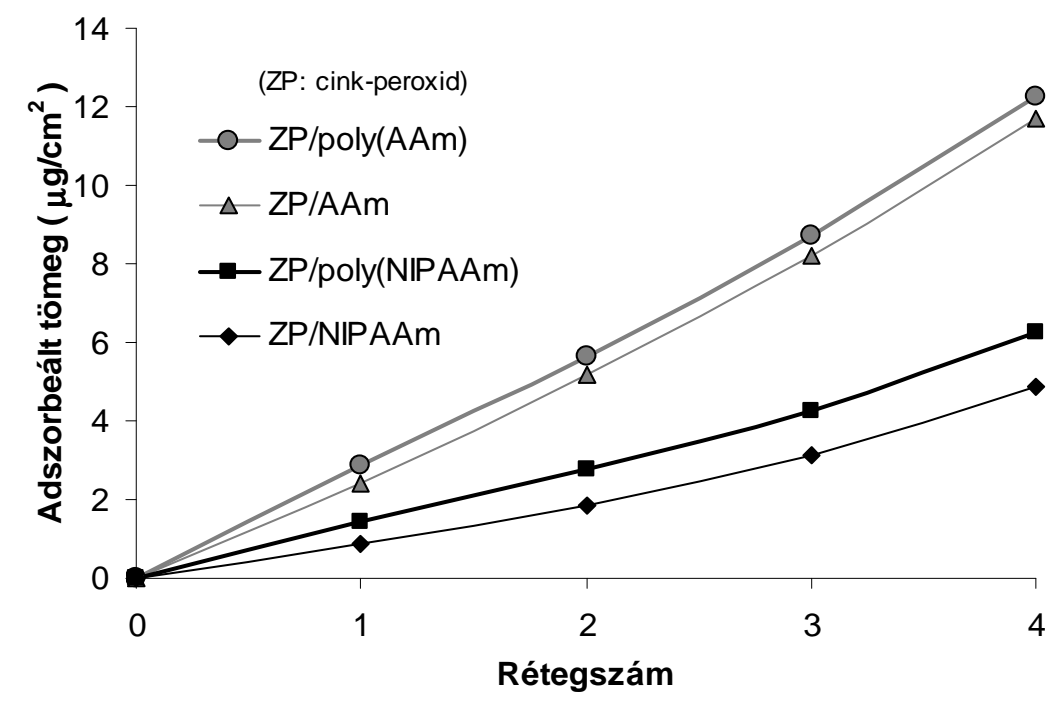

33. ábra Adszorbeált tömeg a QCM-mel való vékonyréteg preparáció során

4. táblázat $A 4$ rétegü hibrid filmek fontosabb fizikai állandói: porozitás (E), effektív törésmutató $\left(n_{\text {eff }}\right)$, sürüség $(\rho)$ és rétegvastagság $(d)$

\begin{tabular}{ccccc}
\hline Hybrid film & $\boldsymbol{\varepsilon}$ & $\begin{array}{c}\mathbf{n}_{\text {eff }} @ \mathbf{n m} \\
\mathbf{n m}\end{array}$ & $\begin{array}{c}\boldsymbol{\rho} \\
\left(\mathrm{g} / \mathbf{c m}^{\mathbf{3}}\right)\end{array}$ & $\begin{array}{c}\mathbf{d} \\
(\mathbf{n m})\end{array}$ \\
\hline $\mathrm{ZnO}_{2} / \mathrm{NIPAAm}$ & 0.400 & 1.122 & 1.796 & 27 \\
$\mathrm{ZnO}_{2} /$ PNIPAAm & 0.302 & 1.143 & 2.094 & 30 \\
$\mathbf{Z n O}_{2} / \mathbf{A A m}$ & 0.519 & 1.097 & 1.443 & 79 \\
$\mathbf{Z n O}_{2} / \mathbf{P A A m}$ & 0.483 & 1.105 & 1.549 & 81 \\
\hline
\end{tabular}

\section{A cink-peroxid/térhálós polimer vékonyrétegek vizsgálata atomerő mikroszkópiával}

A $\mathrm{ZnO}_{2} / \mathrm{PAAm}$ és $\mathrm{ZnO}_{2} / \mathrm{PNIPAAm}$ vékonyrétegek $\mathrm{AFM}$ vizsgálata is a korábbi megállapításainkat támasztja alá: a 34. ábra bal oldalán a 12 kettősrétegü $\mathrm{ZnO}_{2} / \mathrm{PAAm}$ film nagyobb aggregátumokkal közel egyenletesen borított, míg jobb oldalon a $\mathrm{ZnO}_{2} / \mathrm{PNIPAAm}$ vékonyréteg kisebb részecskékkel egyenetlenül fedett felülete látható. A gyengén töltött NIPAAm monomerek láthatóan kevésbé alkalmasak LbL technikával készített vékonyrétegek előállítására. 
A)

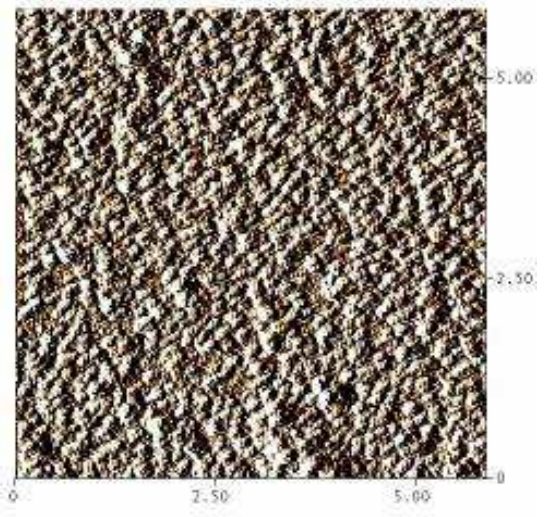

B)

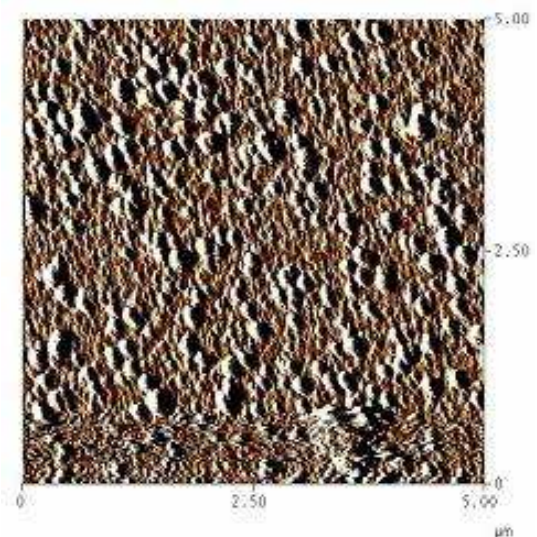

34. ábra $\mathrm{A} 12$ rétegszámú $\mathrm{ZnO} \mathrm{O}_{2} / \mathrm{PAAm}$ (bal oldalon) és $\mathrm{ZnO}_{2} / \mathrm{PNIPAAm}$ (jobb oldalon) vékonyrétegek AFM felvételei

\section{Víz- és etanol gőz adszorpció mérések cink-peroxid/térhálós polimer vékonyrétegeken}

4 kettősrétegü $\mathrm{ZnO}_{2}$ /térhálós polimer hibrid filmeken víz- és etanol gőz adszorpciós kísérleteket végeztem kvarckristály mikromérleggel, hogy megvizsgáljam, a térhálós polimerek (és monomerjeik) vékonyrétegben milyen hasonló illetve eltérö tulajdonságokkal bírnak a tömbi (hidrogél) fázishoz képest. A gözök tenzióját etilénglikol segítségével szabályoztam oly módon, hogy a víz/etilénglikol ill. etanol/etilénglikol elegyek móltörtjével közel- egyenesen arányos gőznyomás alakul ki a folyadék feletti térben (Raoult-törvény: prelativ $=\mathrm{x}_{1} * \mathrm{p}_{\text {telitett }}$ ); tiszta etilénglikol esetén $p=0$ (és $p_{r}=0$ ), tiszta víz ill. etilalkohol esetén pedig $p=p_{\text {telitési }}$ (és $p_{r}=1$ ), a kettő között pedig közel lineárisan skálázódik.

Az víz- és etanol gőz adszorpciós eredmények rendre a 35.a,b,c és d ábrákon láthatók. A grafikonokról és a 36.a,b oszlopdiagramokról az olvasható le, hogy - egy kivétellel - a polimerizáció következtében minden esetben csökkent az adszorbeált mennyiség. Ez azzal magyarázható, hogy míg monomer állapot esetén számos kötőhely áll rendelkezésre a víz- és etanol molekulák számára, addig a polimerek esetében a térháló kialakulásával sok kötőhely eltűnik az adszorptívum elöl. Csak a $\mathrm{ZnO}_{2} / \mathrm{AAm}$ és a $\mathrm{ZnO}_{2} / \mathrm{PAAm}$ hibridek etanol adszorpciójánál volt megfigyelhető a növekedés a polimerizált forma javára. A kísérleteket elvégeztem oly módon is, hogy az elegyek tenzióját nem etilénglikollal (EG) szabályoztam, hanem víz/etanol elegyeket használtam. A grafikonokon ezeket az eredményeket is ábrázoltam (fekete rombuszokkal). Az AAm alapú filmek esetén megállapítottam, hogy a vízgőz móltörtjének növekedésével arányosan növekszik az adszorbeált mennyiség, ezzel ellentétben a NIPAAm alapú vékonyrétegekkel végzett mérések során a fajlagos adszorbeált mennyiség maximum jelleget mutat $x_{1}(v i ́ z)=0.6$ móltört értéknél. 


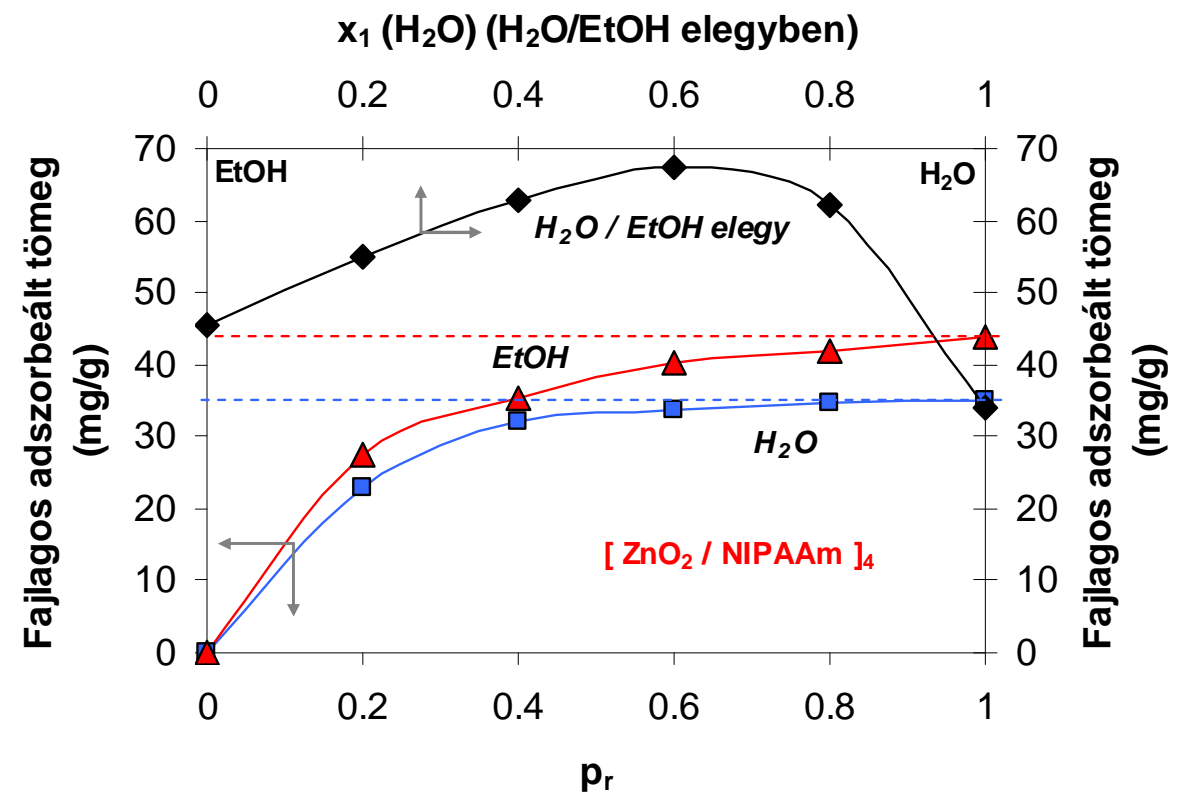

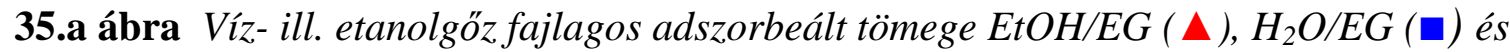
$\mathrm{H}_{2} \mathrm{O} / \mathrm{EtOH}(\diamond)$ elegyek feletti göztérböl 4 rétegü $\mathrm{ZnO}_{2} / \mathrm{NIPAAm}$ hibrid vékonyréteg esetén

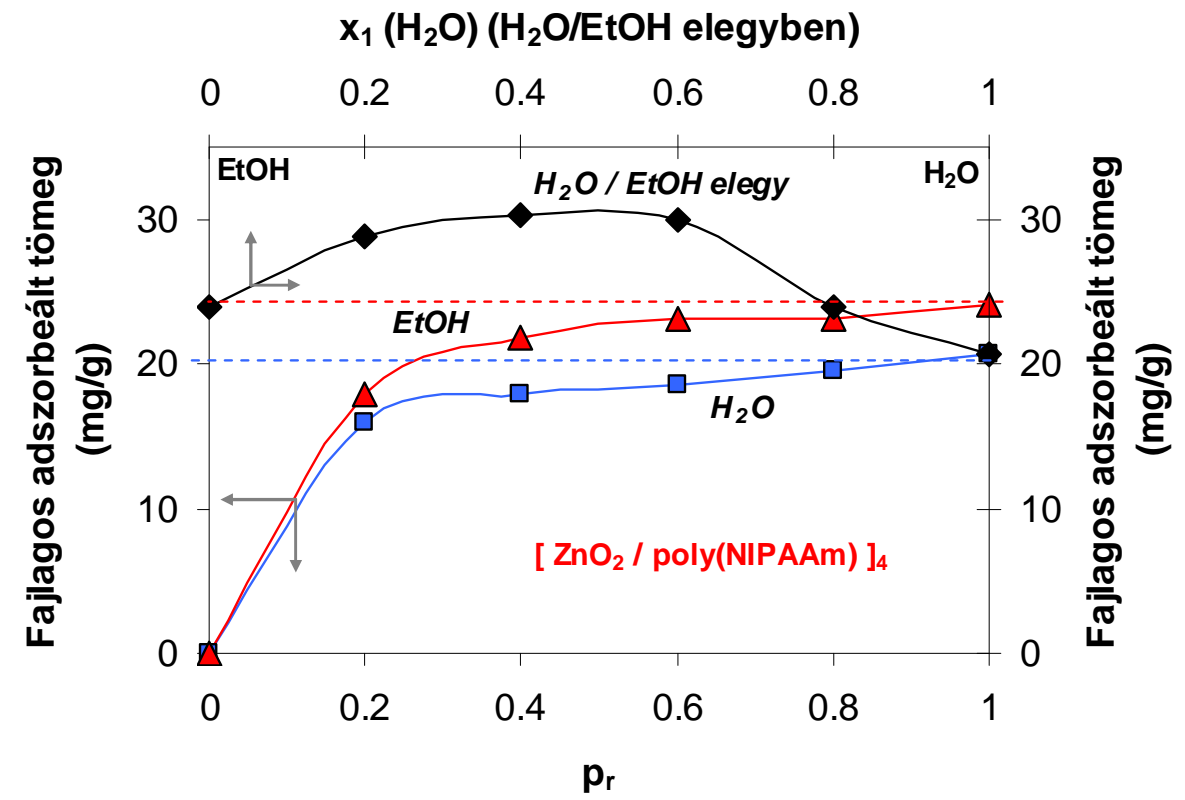

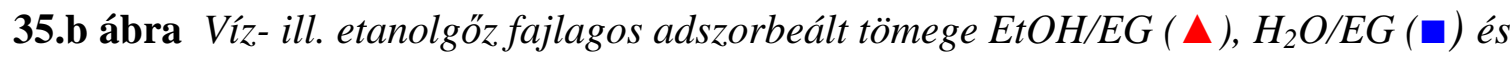
$\mathrm{H}_{2} \mathrm{O} / \mathrm{EtOH}(\diamond)$ elegyek feletti göztérböl 4 rétegü $\mathrm{ZnO}_{2} / P N I P A A m$ hibrid vékonyréteg esetén 


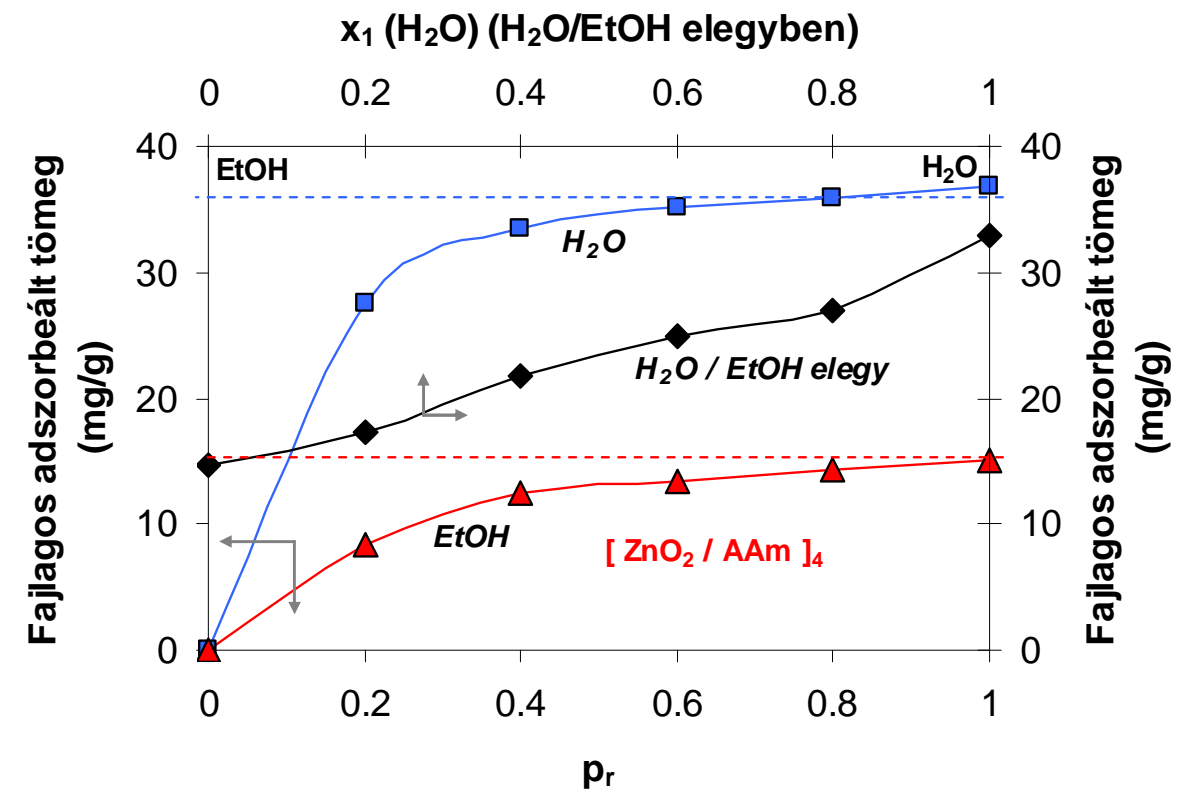

35.c ábra Víz-ill. etanolgöz fajlagos adszorbeált tömege EtOH/EG (४), $\mathrm{H}_{2} \mathrm{O} / \mathrm{EG}$ (口) és $\mathrm{H}_{2} \mathrm{O} / \mathrm{EtOH}(\diamond)$ elegyek feletti göztérböl 4 rétegü $\mathrm{ZnO}_{2} / \mathrm{AAm}$ hibrid vékonyréteg esetén

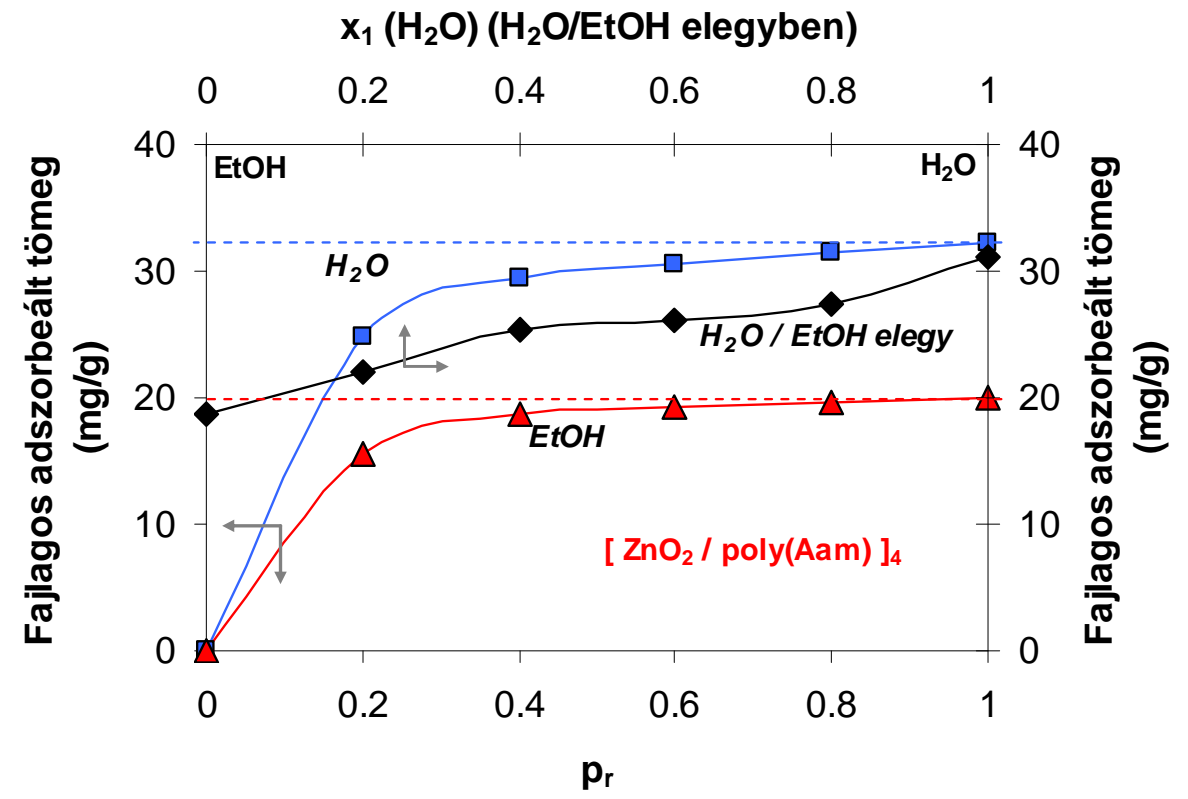

35.d ábra Víz- ill. etanolgöz fajlagos adszorbeált tömege EtOH/EG (山), $\mathrm{H}_{2} \mathrm{O} / \mathrm{EG}(\mathbf{\square})$ és $\mathrm{H}_{2} \mathrm{O} / \mathrm{EtOH}(\downarrow)$ elegyek feletti göztérből 4 rétegü $\mathrm{ZnO}_{2} / \mathrm{PAAm}$ hibrid vékonyréteg esetén

Az izotermák linearizálásával és a pontokra történő egyenesek illesztésével meghatározható a monomolekulás borítottsághoz tartozó anyagmennyiség $\left(n_{m}^{s}\right)$, ami az egyenesek meredekségének reciproka. A kapott adatokat az 5. táblázat tartalmazza. A számolt $n_{m}^{s}$ értékekből meghatároztam a filmek $a_{L}^{s}{ }_{L}=n_{m}^{s} \cdot a_{m}$ fajlagos felületét (ahol $a_{m}$ a 
molekula fajlagos felületigénye - vízmolekula: $80 \mathrm{~m}^{2} / \mathrm{mmol}$, etanol molekula: $120 \mathrm{~m}^{2} / \mathrm{mmol}$ ), valamint a $V^{s}=n_{m}^{s} \cdot V_{m}$ fajlagos adszorbeált folyadéktérfogatot (ahol $\mathrm{V}_{\mathrm{m}}$ a moláris térfogat). A 4. és 5. táblázat adatai jól összhangban vannak. Az effektív törésmutató ( $\left.\mathrm{n}_{\mathrm{eff}}\right)$ és a sürüség ( $\rho)$ növekszik a porozitás $(\varepsilon)$ csökkenésével, míg a fajlagos felület növekedésével a monomolekulás borítottsághoz tartozó anyagmennyiség is emelkedik.

5. táblázat A 4 réteges nanohibridek fajlagos adszorbeált mennyisége $\left(n_{m}{ }^{s}\right)$, a fajlagos adszorbeált folyadék mennyisége $\left(V^{s}\right)$ és fajlagos felülete $\left(a_{L}{ }^{s}\right)$

\begin{tabular}{crccccc}
\hline & \multicolumn{2}{c}{$\begin{array}{c}\mathbf{m}_{\mathrm{m}}{ }^{\mathrm{s}} \\
(\mathbf{m g} / \mathbf{g})\end{array}$} & \multicolumn{2}{c}{$\begin{array}{c}\mathbf{a}_{\mathrm{L}}{ }^{\mathbf{s}} \\
\left(\mathbf{m}^{2} / \mathbf{g}\right)\end{array}$} & \multicolumn{2}{c}{$\begin{array}{c}\mathbf{V}^{\mathrm{s}} \\
\left(\mathbf{c m}^{3} / \mathbf{g}\right)\end{array}$} \\
\cline { 2 - 7 }$\left(\mathbf{Z n O}_{2} / \ldots\right)$ & $V^{\prime} z$ & Etanol & $V^{\prime} z$ & Etanol & $V^{\prime} z$ & Etanol \\
\hline NIPAAm & 34.236 & $\mathbf{4 1 . 5 3 8}$ & 152.16 & 108.34 & 0.034 & $\mathbf{0 . 0 5 2}$ \\
PNIPAAm & 19.674 & $\mathbf{2 3 . 2 7 6}$ & 87.44 & 60.74 & 0.019 & $\mathbf{0 . 0 2 9}$ \\
AAm & $\mathbf{3 5 . 4 0 6}$ & 14.122 & 157.36 & 36.85 & $\mathbf{0 . 0 3 5}$ & 0.018 \\
PAAm & $\mathbf{3 1 . 3 3 8}$ & 19.55 & 139.28 & 50.99 & $\mathbf{0 . 0 3 1}$ & 0.025 \\
\hline
\end{tabular}

\section{Összehasonlítás a tömbi fázis eredményeivel}

A részlegesen hidrofil/hidrofób hibridek közel azonos tömegü vizet és etanolt kötöttek meg, valamivel több etanolt (36.a ábra), míg jelentősen nagyobb tömegü vizet adszorbeáltak a dominánsan hidrofil vékonyrétegek (36.b ábra). Amint az ábrákból kitünik, az eredmények jó összhangban állnak a tömbi fázisban kapott adatokkal.

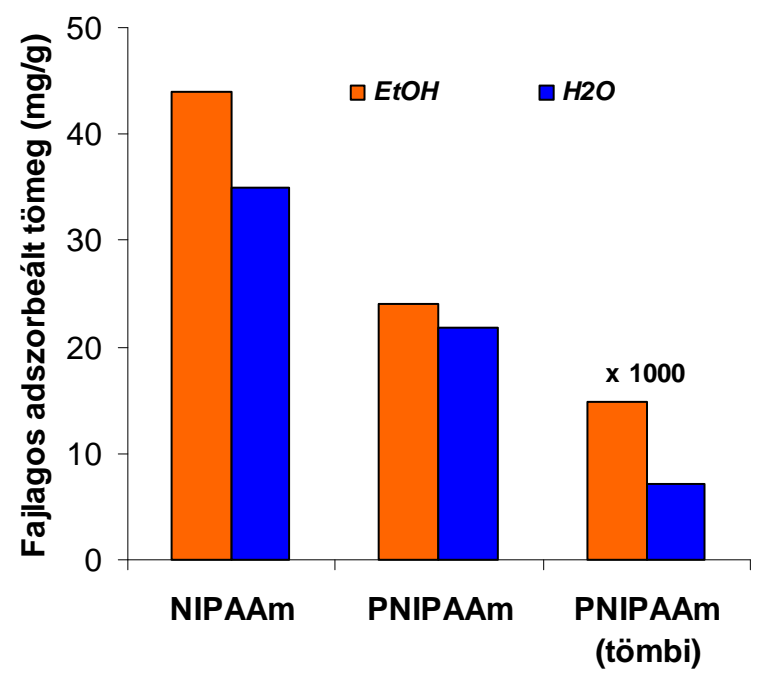

36.a ábra $A 4$ rétegü $\mathrm{ZnO}_{2} / \mathrm{NIPAAm}, \mathrm{ZnO}_{2} / P N I P A A m$ és a tömbfázisbeli PNIPAAm „géltest” által megkötött víz tömege 


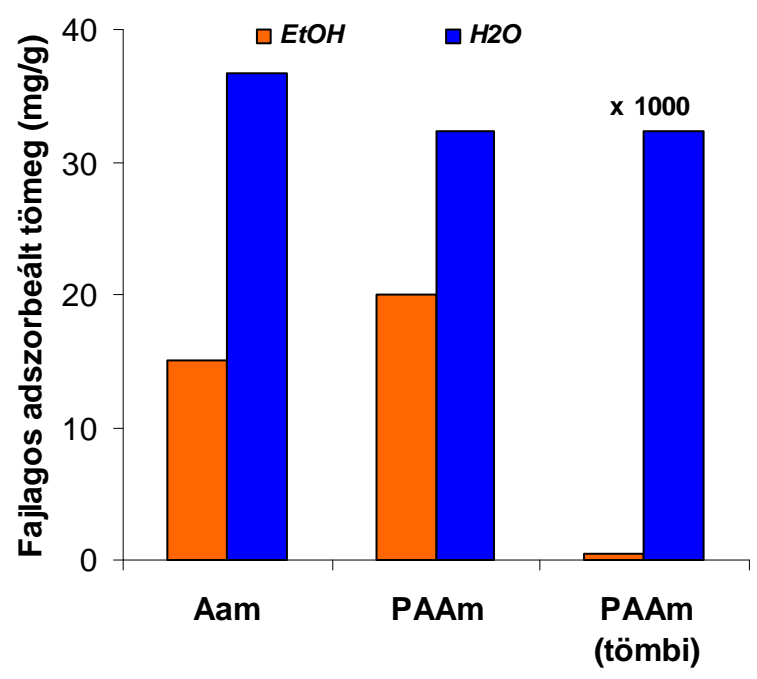

36.b ábra $A 4$ rétegü $\mathrm{ZnO}_{2} / A A m, \mathrm{ZnO}_{2} / P A A m$ és a tömbfázisbeli PAAm „, géltest” által megkötött víz tömege

\subsection{Pórusos önrendeződő vékonyrétegek törésmutató változásának mérésén alapuló gőzszenzor bemutatása}

A 3.3.9 fejezetben leírtaknak megfelelően a gőzszenzor bemutatására ebben a szakaszban térek ki, mert a jelenleg ismert és elérhető irodalomban nem találtam ilyen elven müködő készüléket, vagy akár kísérleti berendezést. Közismert, hogy mind a felületi plazmon rezonancia (SPR) készülékek, mind az optikai hullámvezető technikán alapuló bioszenzor (OWLS) törésmutató változás mérésén alapuló optikai szenzorok, ám egyik sem vékonyréteg felületéről visszaverődő, interferenciával terhelt fény színképének feldolgozásán alapuló elven müködik. Másfelől érzékelő felületük előállítása drága és bonyolult csúcstechnológiát igényel (SPR chip: arany, nagyvákuum, OWLS chip: 1800/mm optikai rács), ezzel szemben az önrendeződő hibrid vékonyrétegek előállítása lényegesen egyszerübb és olcsóbb.

Az alábbiakban bemutatom az általam fejlesztett szenzor általános müködési elvét, majd két különböző felületmódosító szerrel elért eredményeimet taglalom. A korábban bemutatott $\mathrm{ZnO}_{2}$ tartalmú hibrid vékonyrétegek önmagukban nem szelektívek, így szenzorként való alkalmazásuk nem lehetséges, ezért alkalmaztam különböző felületmódosító szereket. Elsőként a butil-triklórszilánnal (BTS) módosított, ezáltal etilalkoholra érzékenyített $\mathrm{ZnO}_{2} / \mathrm{PSS}$ vékonyrétegen elért eredményeket tárgyalom, ezt követően pedig oktántiollal borított arany nanorészecskékkel kezelt - hidrofobizált - $\mathrm{ZnO}_{2} / \mathrm{PSS}$ film tulajdonságait részletezem. Kísérletet tettem a fajlagos adszorbeált mennyiség ill. az adszorptívum/film 
tömegtört és a törésmutató változás közt összefüggést találni, melyhez kvarckristály mikromérleggel (QCM) végzett mérési eredményeket használtam fel. A felületmódosító szerek előminősítését szintén QCM -mel, valamint peremszög méréssel végeztem.

\subsection{1. Általános múködési alapelvek bemutatása}

A szenzor általános működési elvének részletes bemutatását az 1. számú függelékben taglalom, mert annak ellenére, hogy ezek a részletek nélkülözhetetlenek a későbbiekben bemutatott eredmények eléréséhez, mégis ennek törzsét főként technikai és számítástechnikai megfontolások képezik, nem pedig fizikai-kémiai megállapítások. A fejezet főbb pontjai:

- Gázkeverö rendszer leírása (lsd. függelék)

- Hömérséklet meghatározás ismertetése (lsd. függelék)

- Párolgási sebesség meghatározása (lsd. függelék)

- $\Delta \lambda-\Delta n$ (hullámhossz eltolódás-törésmutató változás) kalibrációja (lsd. függelék)

\section{- Szélsőérték keresés}

A mérések sarkalatos pontja a szélsőérték keresése. Ennek egyik oka, hogy a müszer zajszintje meghaladja azt az értéket, amennyi különbség lehet két szomszédos pixelen mért intenzitás érték között. Azaz, ha minden időpillanatban keressük egy hullámhossz ablak legalacsonyabb intenzitású elemét, akkor nagy gyakorisággal találunk olyan elemet, amely nem a valódi szélsőérték, csak a zaj által torzított jelalak legalacsonyabb pontja (37. ábra).

A valódi szélsőérték megtalálásához polinom illesztést alkalmaztam. A cosinus-függvény Taylor-sorba való fejtésével elérhetjük, hogy egy 13 tagú sor már másfél periódust teljes pontossággal lefedjen. Számunkra elegendő egy periódus illesztése is, így kilencedfokú polinom illesztését végeztem el. A 38. ábrán látható ennek kiváló pontossága.

A 39. ábrán látható, hogy a reflexió spektrumra történő illesztés, majd az illesztett görbe szélsőértékének keresésével jelentősen javul a kapott görbe minősége, eredményeképpen kiváló hatásfokú simítást érünk el (megjegyzés: ez esetben természetesen nem hagyományos értelemben vett simításról van szó, hiszen nem utólagosan végzünk müveletet az adatsorral, hanem egy zajos jelre történö illesztéssel hatékonyabban keressük a görbe - valódi minimumát). 


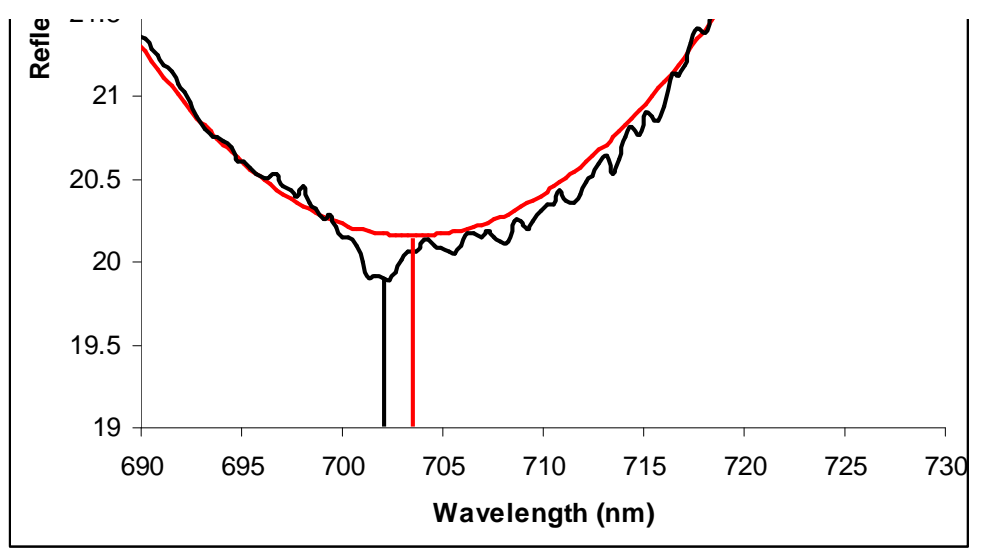

37. ábra A görbe valódi szélsöértéke (pirossal) és a viszonylag magas zajszint miatti minimális intenzitás (feketével) szemléltetése

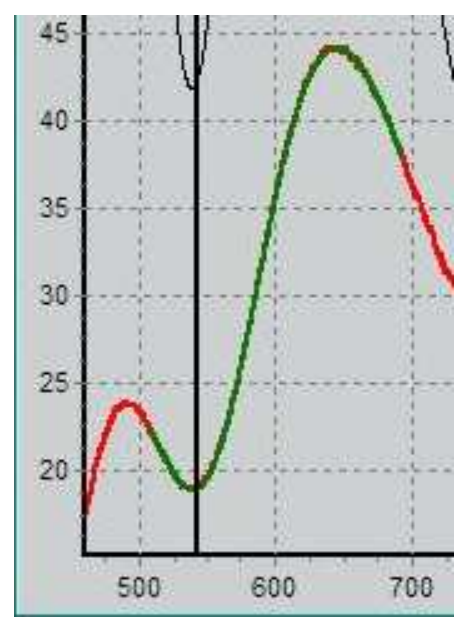

38. ábra Az eredeti (piros) és az illesztett (zöld) függvény összehasonlítása (képernyöfénykép)
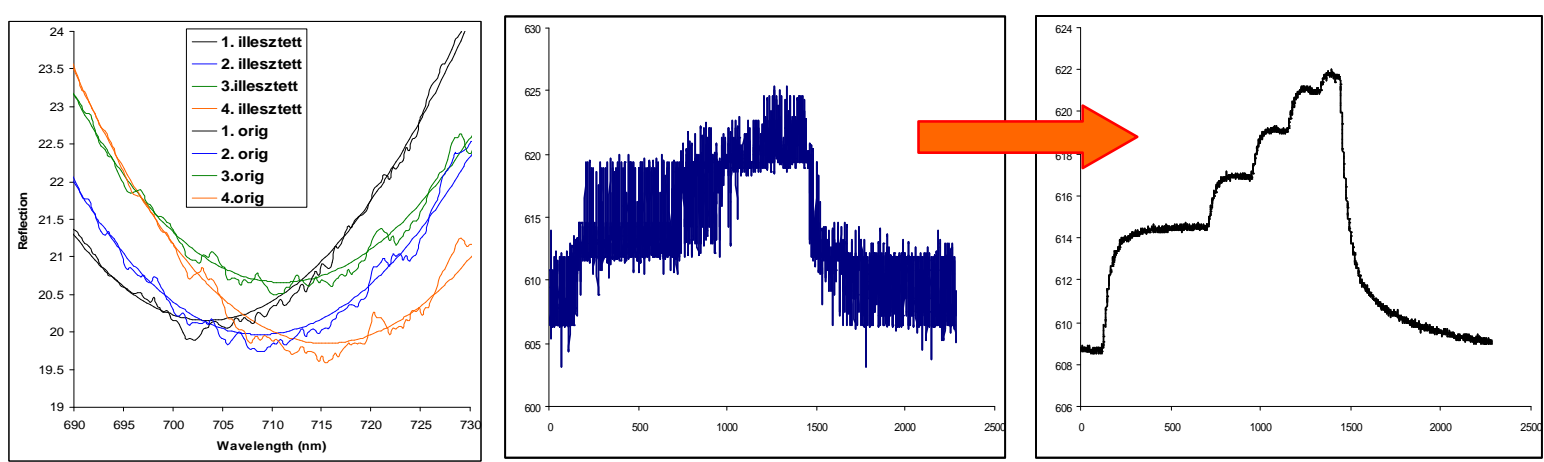

39. ábra A reflexió spektrumok adott szakaszára történö illesztés (bal szélen), az eredeti görbén talált szélsőértékek az idö függvényében (középen) és az illesztett görbe szélsöértékei (jobb szélen) az idő függvényében 
A szélsőérték meghatározását még jobban pontosítottam a következő megfontolással: a müszer felbontása hozzávetőlegesen $0.4 \mathrm{~nm}$, azaz másfél nanométeren belül átlagosan 3 pixel helyezkedik el. A minimum-keresési eljárás az ezen pontokhoz tartozó intenzitások közül választja ki a legkisebbet, azaz 0.4 nanométerenként ad egy értéket. Ám egyáltalán nem biztos, hogy az illesztett polinom igazi minimum értéke valamely diszkrét pontra esik ezek közül. Éppen ezért a megtalált, diszkrét pontra eső minimum körüli \pm 1 pixel tartományt (jobbról és balról) felbontottam további 150-150 mesterséges pontra, kiszámoltam a korábban illesztett polinom értékeit ezeken a helyeken, és elvégeztem újra egy szélsőérték keresést. Ezzel tovább finomítottam a keresést. Ennek látható eredménye az, hogy a 0.4 nanométerenként lépcsősen emelkedő ill. csökkenő görbe „lépcsőfokai” kisimulnak, egyenletesen változóvá válnak (40. ábra). Az ábra középső képén egyértelműen látható, hogy az első minimum keresési eljárásban megtalált szélsőérték helye nem egyezik a hely szük környezetére illesztett polinom minimum helyével, ez utóbbi tehát valóban pontosítja az első eljárás eredményét.
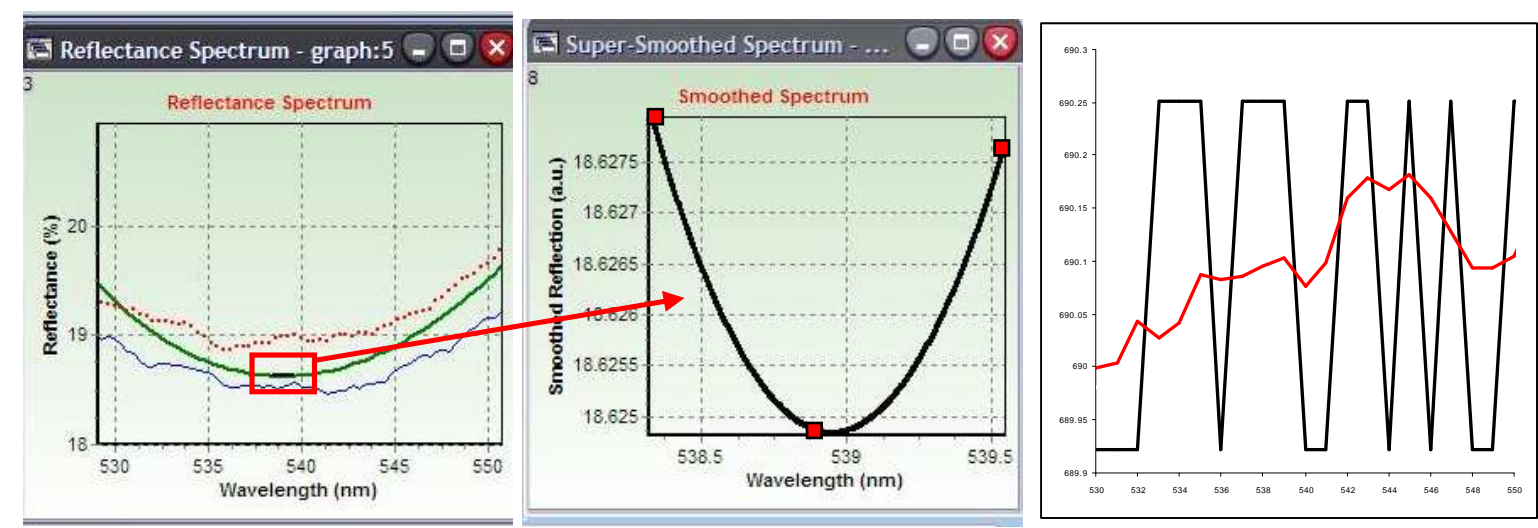

40. ábra bal szélen: az eredeti (piros), az illesztett (zöld) és a minimum szük környezetére illesztett (kis fekete a piros keretben) görbék; középen: a minimum környezetére illesztett görbe kinagyított ábrán (fekete vonal) és az eredeti pixelek helye (piros négyzet); jobb szélen: az illesztett (fekete) és a minimum szük környezetére illesztett (piros) görbék minimum helyei az idö függvényében;
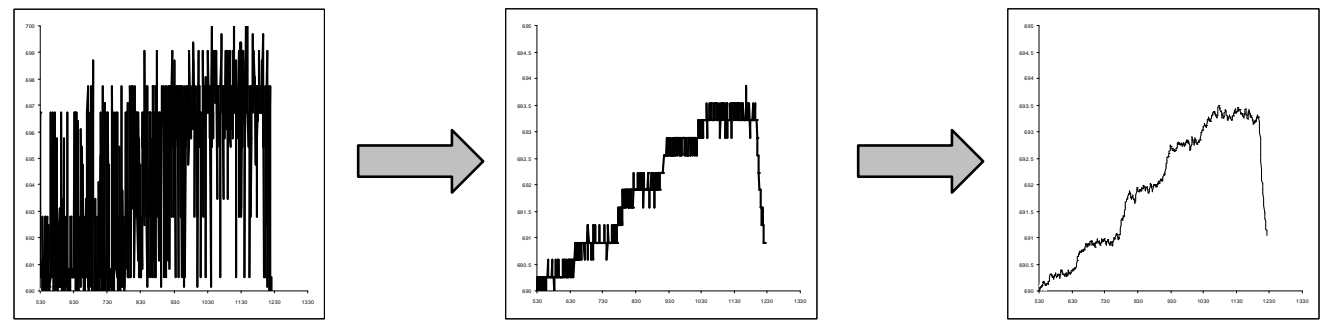

41. ábra Az eredeti, az, illesztett, és a finomított illesztéssel kapott görbék 


\subsubsection{A felületmódosítások előminősítése QCM -mel és peremszög méréssel}

$\mathrm{Az}$ eredeti és felületmódosított mintákat elsőként kvarckristály mikromérleggel és peremszög méréssel jellemeztem. Számos felületmódosító szer került a látókörömbe (szilánok, tenzidek, tiolok), melyek közül a legalkalmasabbak kiválasztására e két módszert választottam. Az interferencia mérések során alkalmazott 20-30 kettősréteg számú vékonyrétegek előállítása időigényes feladat, ezzel szemben a kvarckristály mikromérleg és a peremszög mérés nem igényel több réteget, mint ami a teljes borítottsághoz szükséges. Ez a feltétel már 2 kettősrétegnél teljesül, amit az alábbi elektronmikroszkópos (SEM) kép is alátámaszt.

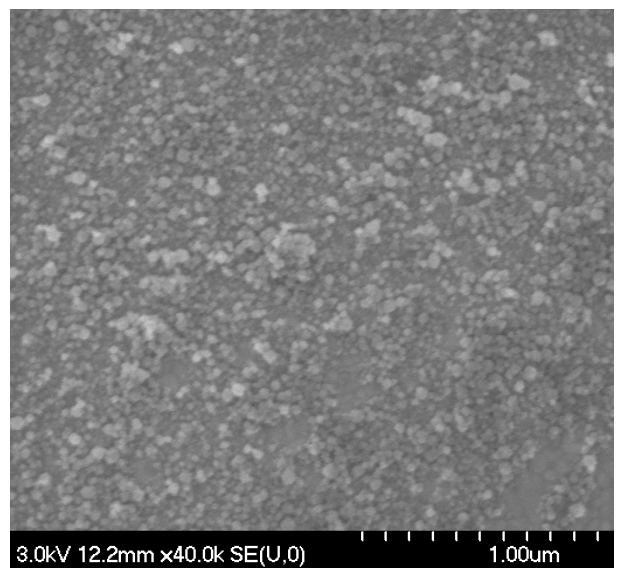

42. ábra 2 kettösrétegü $\mathrm{ZnO}_{2} / P S S$ hibrid vékonyrétegröl készült SEM felvétel

A kvarckristály mikromérleg kristályára felépített 2 kettősrétegü filmeken mértem különböző gőzök adszorpcióját (metanol, butanol, toluol, hexán), a mérési eredményeket az 43. $a, b$ és $c$ ábrákon mutatom be. A kezeletlen $\mathrm{ZnO}_{2} / \mathrm{PSS}$ hibrid esetében megállapítottam, hogy a $p_{r}=0-0.5$ tartományban nincs jelentős különbség az adszorbeált anyagmennyiségek között a különböző minőségü gőzök esetén. Ezzel szemben butiltriklórszilánnal (BTS) való felületmódosítás után a vékonyréteg különösen érzékennyé vált metil- és etilalkohol gőzére, az adszorbeált mennyiség $p_{r}=0.5$ értéken közel duplája, nagyobb relatív gőznyomások esetén pedig 4-5-szöröse a megkötődött hexán ill. toluol mennyiségének. Ezzel párhuzamosan a filmen mért peremszög értéke is nött $8^{\circ}$-kal. Ehhez hasonlóan, az oktántiollal borított arany nanorészecskékkel (OT-AuNR) módosított $\mathrm{ZnO}_{2} / \mathrm{PSS}$ filmek esetén is megnövekedett a mért peremszög értéke, ám ez esetben $19^{\circ}$-kal, valamint a réteg 3-4 -szer több hexánt adszorbeált, mint alkohol ill. toluol gőzt. 

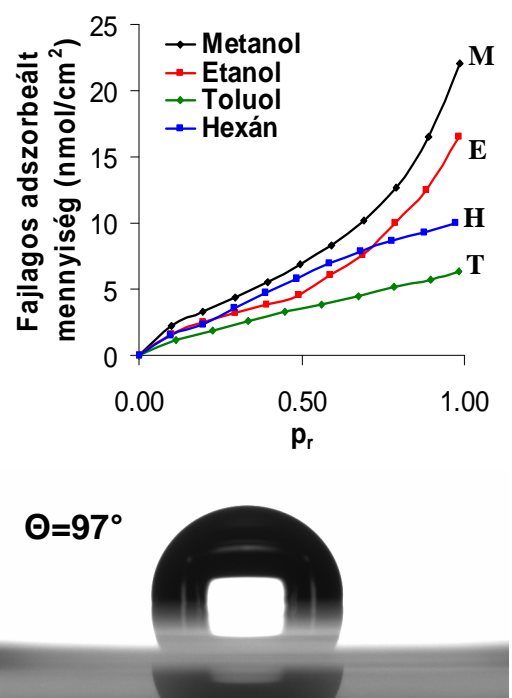

43.a ábra Eredeti

2 kettösréteg számú $\mathrm{ZnO}_{2} / P S S$ mintán mért metanol, etanol, toluol és hexán göz adszorpció, valamint vízcseppel mért peremszög
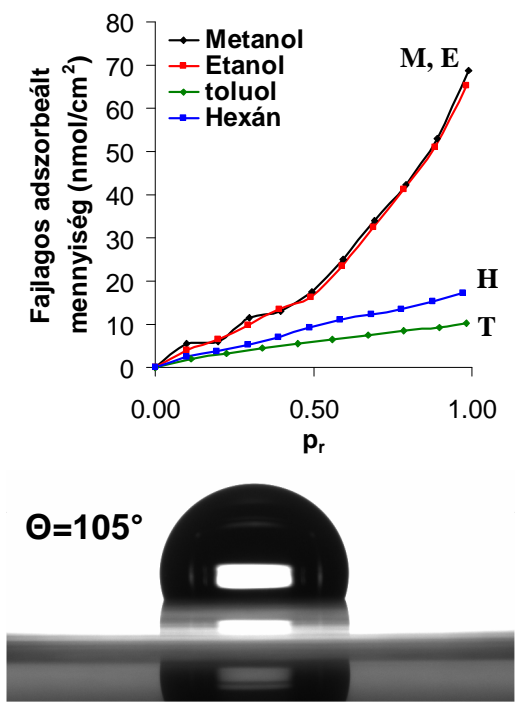

43.b ábra

Butiltriklórszilánnal módosított

2 kettösréteg számú $\mathrm{ZnO}_{2} / \mathrm{PSS}$ mintán mért metanol, etanol, toluol és hexán göz adszorpció, valamint vízcseppel mért peremszög
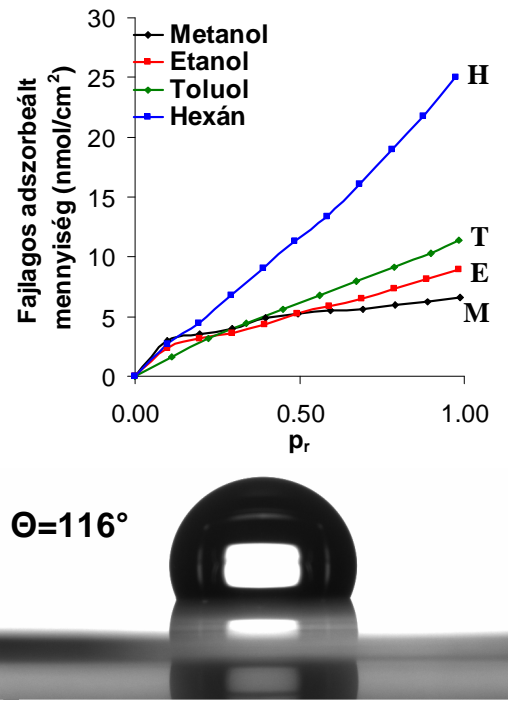

43.c ábra Oktántiollal borított arany nanorészecskékkel módosított

2 kettösréteg számú $\mathrm{ZnO}_{2} / \mathrm{PSS}$ mintán mért metanol, etanol, toluol és hexán göz adszorpció, valamint vízcseppel mért peremszög

Megállapítottam tehát, hogy a BTS-nal és OT-AuNR -kel való felületmódosítás alkalmas a vékonyrétegek szelektivitásának növelésére, elöbbi alkoholok, utóbbi pedig hexán gőzének adszorpcióját segíti elő nagymértékben. Így a továbbiakban e két felületmódosító szerrel folytattam a kísérleteket.

\subsection{3. $\mathrm{ZnO}_{2} / \mathrm{PSS}$ film felületmódosítása butiltriklórszilánnal}

A 3.2.1. fejezetben bemutatott technikával előállított, 20 kettősréteg számú $\mathrm{ZnO}_{2} / \mathrm{PSS}$ hibrid vékonyrétegeken felületmódosítást végeztem el, ehhez elsőként butiltriklórszilán (BTS) 0.01 M hexános oldatát használtam fel.

Megjegyzés: Egy korábbi elökísérletben BTS 0.01 M vizes oldatával végeztem a reakciót, ám ennek során a filmem lemosódott a szilárd hordozó felületéröl. Ennek lehetséges oka, hogy a reakció során a felületi $-\mathrm{OH}$ csoportok lépnek kölcsönhatásba a szilán egyik Cl-Si végzödésével, melynek során kihasad egy $\mathrm{HCl}$ molekula, a felületen pedig egy Zn-O-Si kötésen keresztül létrejön a felületmódosítás. A kihasadó hidrogén-klorid olyan mértékben csökkenti a felület közelében a pH értéket, melyen a $\mathrm{ZnO}_{2}$ feloldódik, s ily módon a vékonyréteg lemosódik a hordozóról (44. ábra). 


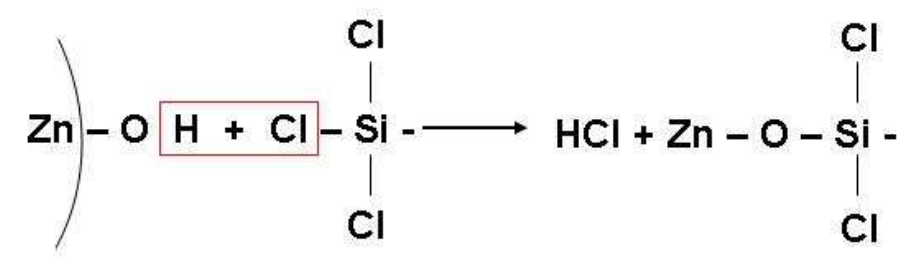

44. ábra Felületi reakció butiltriklórszilánnal való felületmódositás során

Ezen tapasztalatok birtokában tehát $0.01 \mathrm{M}$ hexános oldatból való felcseppentéssel végeztem el a módosítást. UV-látható reflexió spektroszkópiával rögzítettem az eredeti 20 kettősréteg számú $\mathrm{ZnO}_{2} / \mathrm{PSS}$, és az egyszeres ill. kétszeres mennyiségü butiltriklórszilánnal módosított hibrid felületéről visszaverődő fény reflexió spektrumait (45. ábra). Az eredeti film spektrumán kettő minimumhely és egy maximum hely figyelhető meg 427 nm, $530 \mathrm{~nm}$ és 692 nm hullámhosszakon. Mindkét felületmódosítás alkalmával ca. 30-50 ill. 50-80 nm eltolódást figyelhetünk meg a nagyobb hullámhosszak irányába Ezek pontos értékeit a 6. táblázatban foglaltam össze. Az eltolódások oka egyértelműen a felületmódosító anyag - föként pórusokban való - megkötődése általi effektív törésmutató növekedés.

Meghatároztam a vékonyrétegek rétegvastagságát $(d)$, amely $514 \mathrm{~nm}$-nek adódott. Feltételeztem, hogy felületmódosítás során a rétegvastagság nem változik, így állandó $d=514$ $n m$ érték mellett határoztam meg a filmek törésmutatóját. Az eredeti minta törésmutatója 1.267-1.286 értékek közt változik a 400-800 nm hullámhossz tartományban, a butiltriklórszilánnal egyszeresen ill. kétszeresen kezelt vékonyrétegek megnövekedett törésmutatója pedig rendre 1.342-1.374 ill. 1.378-1.416 tartományban van (46. ábra). A Bruggeman-modellel számolva ez azt jelenti, hogy a pórusok törésmutatója hozzávetőlegesen 1.00 -ről 1.11 -re (első kezelés) ill. 1.16 -ra (második kezelés) emelkedik, amit 25 ill. 30 V\% BTS képes előidézni ( $\mathrm{n}_{\mathrm{BTS}}=1.445$, CAS 7521-80-4 adatlap alapján). Tehát az első kezelés alkalmával a pórusok térfogatának közel egynegyedét, a második során közel egyharmadát butiltriklórszilán molekulák tölthetik ki. 


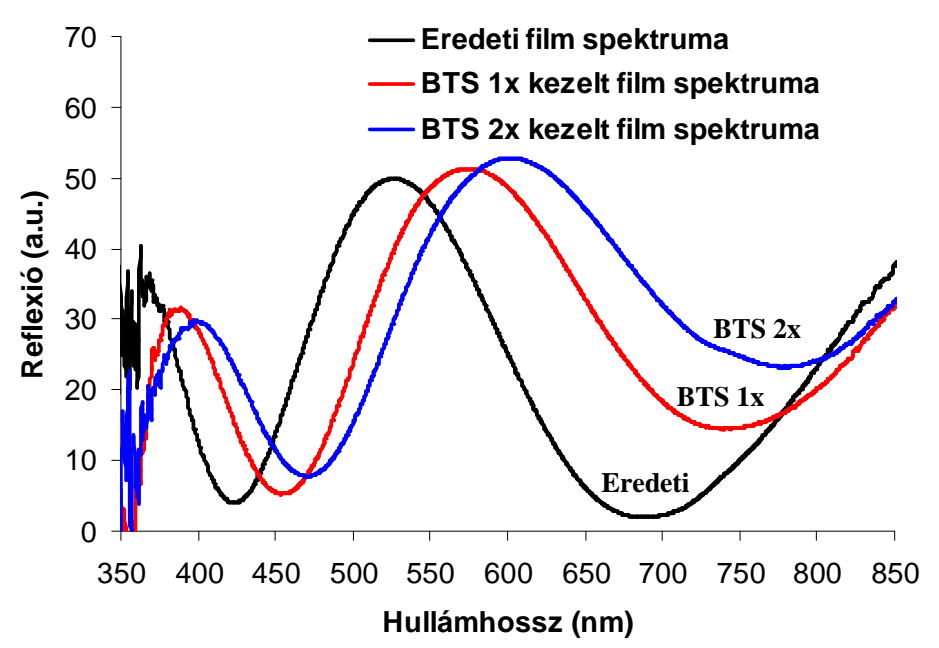

45. ábra Az eredeti (kezeletlen) és a butiltriklórszilánnal (BTS) egyszer ill. kétszer kezelt, 20 kettősréteg számú $\mathrm{ZnO}_{2} / P S S$ hibrid vékonyrétegek reflexiós spektrumai

6. táblázat Az eredeti (kezeletlen) és a butiltriklórszilánnal (BTS) egyszer ill. kétszer kezelt, 20 kettősréteg számú $\mathrm{ZnO}_{2} / P S S$ hibrid vékonyrétegek szélsőértékeihez tartozó hullámhosszak

\begin{tabular}{cccc}
\hline & $\begin{array}{c}\text { 1. minimum helye } \\
(\mathbf{n m})\end{array}$ & $\begin{array}{c}\text { 1. maximum helye } \\
(\mathbf{n m})\end{array}$ & $\begin{array}{c}\text { 2. minimum helye } \\
(\mathbf{n m})\end{array}$ \\
\cline { 2 - 4 } $\begin{array}{c}\text { Eredeti } \mathrm{ZnO}_{2} / \text { PSS hibrid } \\
\text { film }\end{array}$ & 427 & 530 & 692 \\
\hline $\begin{array}{c}\text { BTS-nal egyszer kezelt } \\
\mathbf{Z n O}_{2} / \text { PSS hibrid film }\end{array}$ & 459 & 578 & 748 \\
\hline BTS-nal kétszer kezelt & $(\Delta \lambda=32 \mathrm{~nm})$ & $(\Delta \lambda=48 \mathrm{~nm})$ & $(\Delta \lambda=56 \mathrm{~nm})$ \\
$\mathbf{Z n O}_{2} /$ PSS hibrid film & $(\Delta \lambda=48 \mathrm{~nm})$ & $(\Delta \lambda=72 \mathrm{~nm})$ & $(\Delta \lambda=86 \mathrm{~nm})$ \\
\hline
\end{tabular}

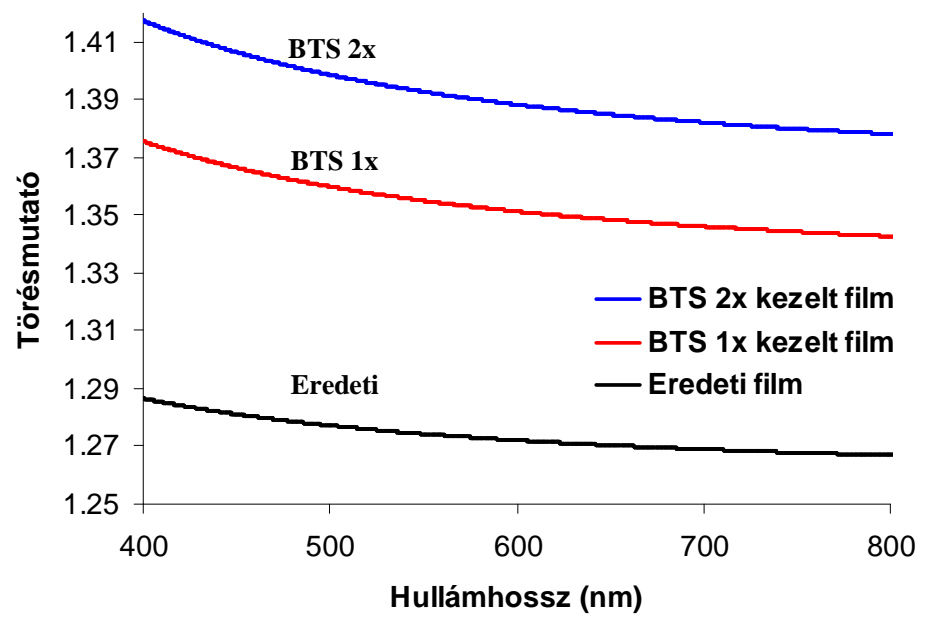

46. ábra Az eredeti (kezeletlen) és a butiltriklórszilánnal (BTS) egyszer ill. kétszer kezelt, 20 kettösréteg számú $\mathrm{ZnO}_{2} / P S S$ hibrid vékonyrétegek törésmutatója a hullámhossz függvényében 400-800 nm tartományban 
A következőkben bemutatom az eredeti és a módosított mintákon végzett adszorpciós mérések eredményeit, amelyek egyben a szenzor müködési elvét is reprezentálják.

A méréseket a reflexió spektrum első és második minimum helyén végeztem. Adszorptívumként víz, etanol és hexán gőzét alkalmaztam, melyeket $p_{r}=0-1$ tartományban állítottam be. Ez vízgőz esetén 0-22 pmm, etanol esetén 0-185 ppm, hexán esetén pedig 0-1074 ppm gőzkoncentráció tartományt jelent. A mérés során ezek az értékek természetesen kisebbek a lehülés miatt.

A mérési eredményeket ábrázoló grafikonokat terjedelmükre való tekintettel a 2. számú függelékben mutatom be. Ebben a szakaszban csak az eredeti $\mathrm{ZnO}_{2} / \mathrm{PSS}$ minta első minimum helyén mért, vízgőz adszorpcióra vonatkozó eredményeket ábrázolom, a méréstechnika részleteinek bemutatása végett.

A 47.a ábrán látható a folyadék hőmérséklete, a mérőcellában lévő gőzkoncentráció és a vékonyrétegen mért törésmutató az első minimumhely kezdeti hullámhosszán, az idő függvényében. A hőmérséklet a számítással összhangban csökken a mérés időtartama alatt, miközben a törésmutató lépésröl-lépésre növekszik, párhuzamosan a göz nitrogén áramban való arányának növelésével. A méröcellában a mérés teljes időtartama alatt állandó $\left(\mathrm{T}=25^{\circ} \mathrm{C}\right)$ hőmérsékletet biztosítva ismerjük minden gőz telítési parciális nyomását, így minden lépésben az adott gőznyomásból kiszámíthatjuk a gőz relatív nyomását $\left(p_{r}\right)$. Az adott $c(p p m)$ -hez, vagy $p_{r}$-hez tartozó törésmutatókat leolvasva nyerjük a 47.b ábrán látható görbéket. Kalibráció után (lsd. 4.4.5. fejezet) ezen mérési adatokból adhatjuk meg a gőzökre vonatkozó adszorpciós izotermákat az adott felületen. A mérés során rögzítettem a minimumhelyhez tartozó hullámhossz eltolódását is, melyböl (kalibráció alapján) számítható a törésmutató változás (47.c ábra).

A teljes méréssorozatra vonatkozó részletes eredményeket a 2. számú függelék tartalmazza. 


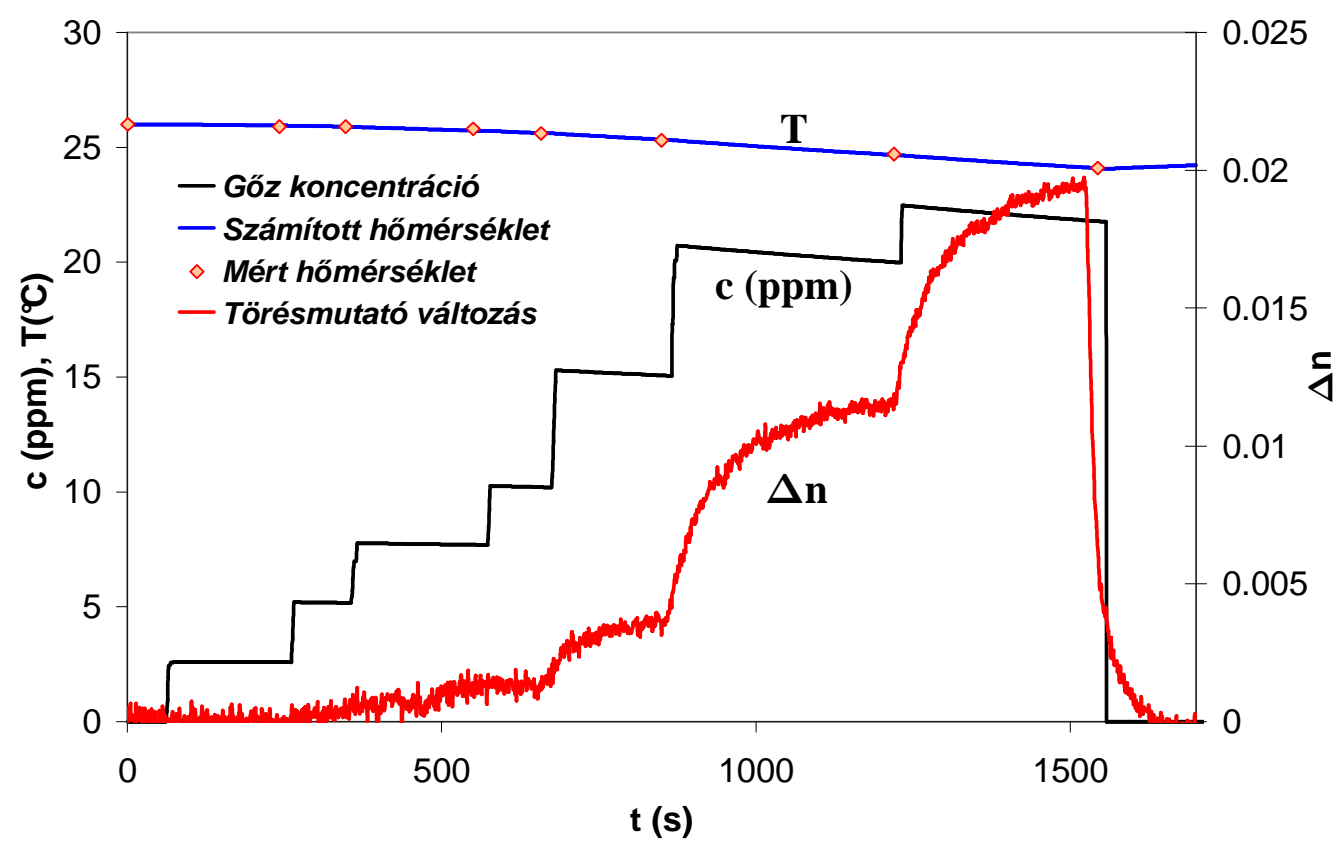

47.a ábra Vízgőz hatására bekövetkezö törésmutató változás 20 kettősrétegü, kezeletlen $\mathrm{ZnO}_{2} / \mathrm{PSS}$ mintán, az elsö minimum helyen $(\lambda=424 \mathrm{~nm}$ ), valamint a gőzkoncentráció és hőmérséklet értéke a kísérlet időtartama alatt

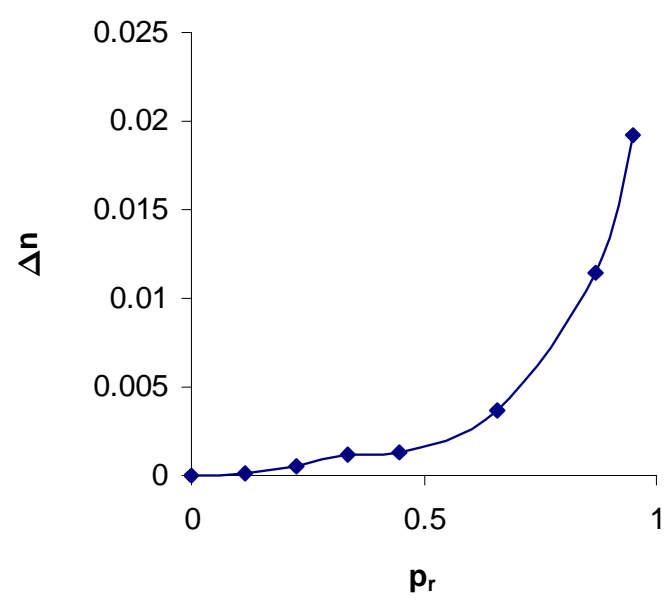

47.b ábra Törésmutató változás a koncentráció ill. a relatív göznyomás függvényében, az elsö minimum helyen ( $\lambda=424 \mathrm{~nm}$ ), 20 kettösrétegü, kezeletlen $\mathrm{ZnO}_{2} / P S S$ mintán, vízgöz jelenlétében 


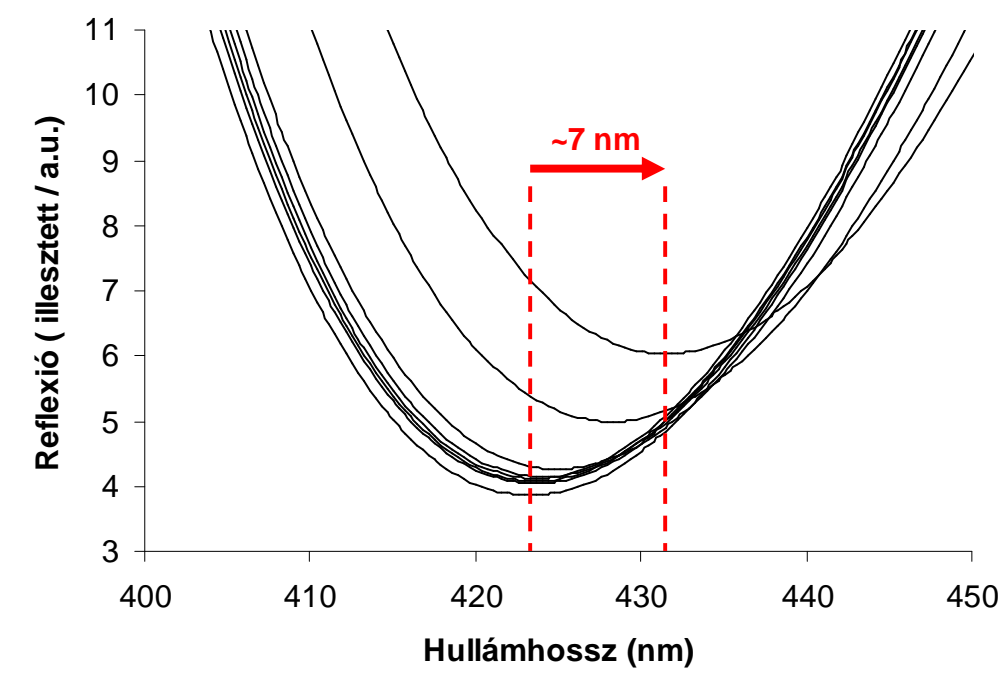

47.c ábra Vízgöz hatására bekövetkező reflexió spektrum eltolódás az első minimum helyen ( $\lambda=424 \mathrm{~nm}), 20$ kettösrétegü, kezeletlen $\mathrm{ZnO}_{2} / \mathrm{PSS}$ mintán, vízgöz jelenlétében

A méréseket elvégeztem eredeti (kezeletlen) és butiltriklórszilánnal egyszer ill. kétszer kezelt felületen, a reflexió spektrum első és második minimumhelyén, víz-, etanol- és hexán gőz jelenlétében. Ezek végeredménye az alábbi ábrákon látható. Tekintettel arra, hogy az eltérő anyagi minőségű gőzök lehülése nem egyező mértékben történik, így a végső relatív gőznyomás nem egyezik, ezért minden esetben a $p_{r}=0-0.5$ tartományon hasonlítom össze az eredményeket.

A 48. ábrán az eredeti 20 kettősréteg számú $\mathrm{ZnO}_{2} / \mathrm{PSS}$ film első ill. második minimum helyén rögzített törésmutató változásokat ábrázoltam víz-, etanol- és hexán adszorpció során. A görbékről leolvasható, hogy a kezeletlen vékonyréteg törésmutatója hexán gőz hatására növekszik a legnagyobb mértékben (első minimum helyen $\Delta \mathrm{n}_{1}=0.008$, második minimum helyen $\left.\Delta \mathrm{n}_{2}=0.0069\right)$, ezt követi az etilalkohol $\left(\Delta \mathrm{n}_{1}=0.005, \Delta \mathrm{n}_{2}=0.0055\right)$, majd a víz által okozott változás ( $\Delta \mathrm{n}_{1}=0015$ és $\left.\Delta \mathrm{n}_{2}=0.0042\right)$. A kisebb alakbeli eltérésektől eltekintve a két minimumhelyen mért tendencia azonos, a felület inkább hidrofób jellegü, melyet a korábban bemutatott $97^{\circ}$ peremszög is alátámaszt. Butiltriklórszilánnal való egyszeres felületmódosítás során a tendencia megváltozik (49. ábra): a víz és hexán adszorpciója által okozott törésmutató változás nem sokkal tér el egymástól, a felületen valamivel több víz tud megkötődni, ám mindkét effektus jóval elmarad az etanol által okozott változástól, amely 4-6 -szorosan felülmúlja azokat. A változások pontos értékeit az alábbi 7. táblázatban foglalom össze. A táblázatból és az ábrákról is egyértelmüen kitűnik, hogy a BTS -nal való második kezelés (49. ábra) az etilalkohol és hexán által okozott törésmutató változásra nincs jelentős 
hatással, ezzel szemben a víz adszorpcióját nagyban elősegíti, az etanollal csaknem azonos szintre kerül (50. ábra).

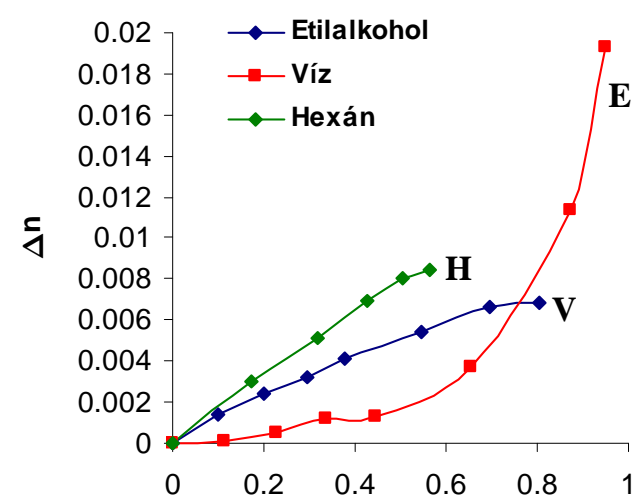

$p_{r}$

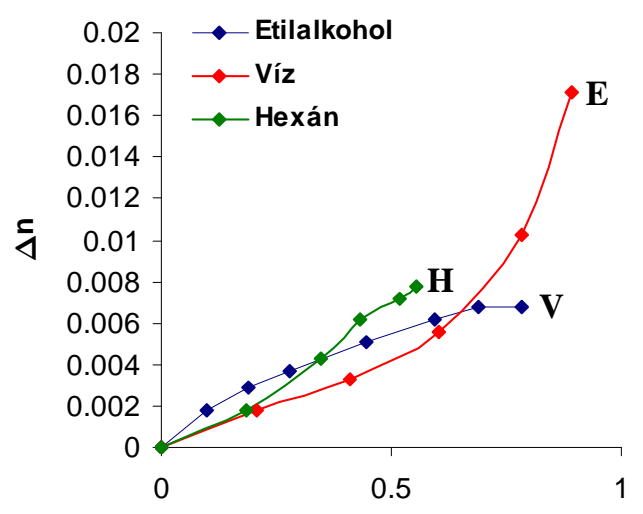

$p_{\mathrm{r}}$

48. ábra Törésmutató változás a relatív göznyomás függvényében, az elsö minimum helyen ( $\lambda=424 \mathrm{~nm}$, bal oldalon) ill. a második minimum helyen ( $\lambda=690 \mathrm{~nm}$, jobb oldalon), 20 kettösrétegü, kezeletlen $\mathrm{ZnO}_{2} / \mathrm{PSS}$ mintán, víz-, etanol-és hexán göz jelenlétében

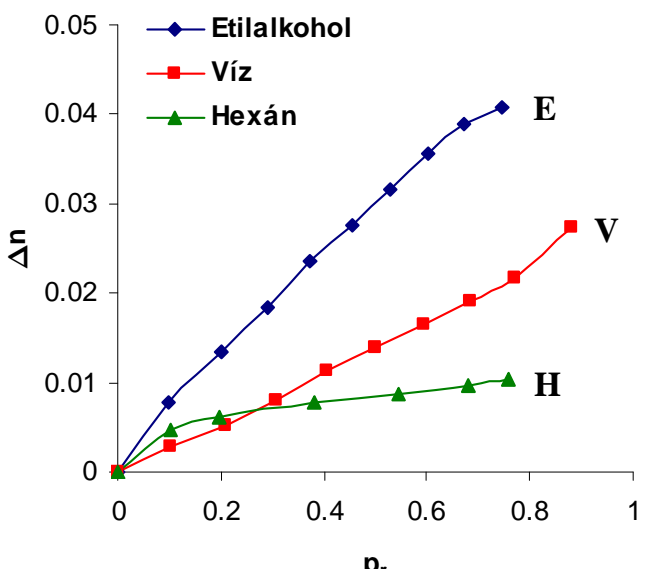

$\mathrm{pr}_{\mathrm{r}}$

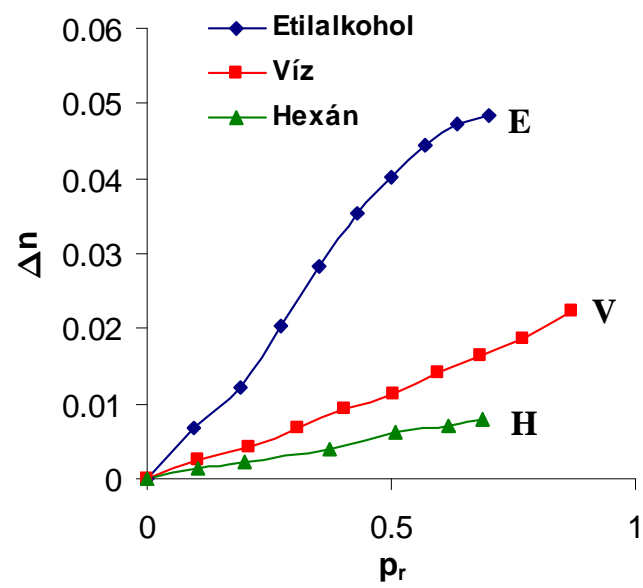

pr

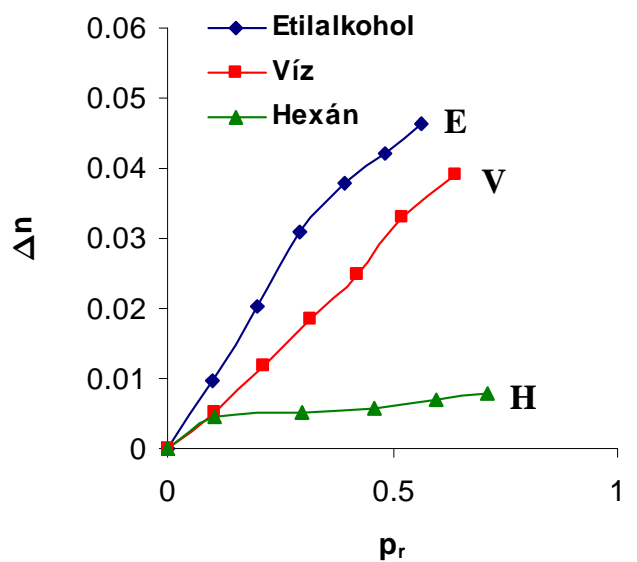

49. ábra Törésmutató változás a relatív göznyomás függvényében, az elsö minimum helyen $\lambda=459 \mathrm{~nm}$, fent bal oldalon) ill. a második minimum helyen ( $\lambda=743 \mathrm{~nm}$, fent jobb oldalon), 20 kettösrétegü, BTS-sel egyszer kezelt $\mathbf{Z n O}_{2} / \mathbf{P S S}$ mintán, valamint a második minimum helyen ( $\lambda=778 \mathrm{~nm}$, lent), 20 kettösrétegü, BTS-sel kétszer kezelt $\mathrm{ZnO}_{2} / \mathrm{PSS}$ mintán víz-, etanol- és hexán göz jelenlétében 
Megállapítottam tehát, hogy az egyszeres kezelés az etanolra való specifikus érzékenységet növeli, a második kezelés pedig a film hidrofil tulajdonságát erösíti meg a hidrofóbbal szemben.

7. táblázat Viz-, etanol- és hexán adszorpció által okozott törésmutató változás az eredeti és butiltriklórszilánnal egyszer ill. kétszer kezelt 20 kettösrétegü $\mathrm{ZnO}_{2} / P S S$ vékonyréteg reflexió spektrumának második minimumhelyén.

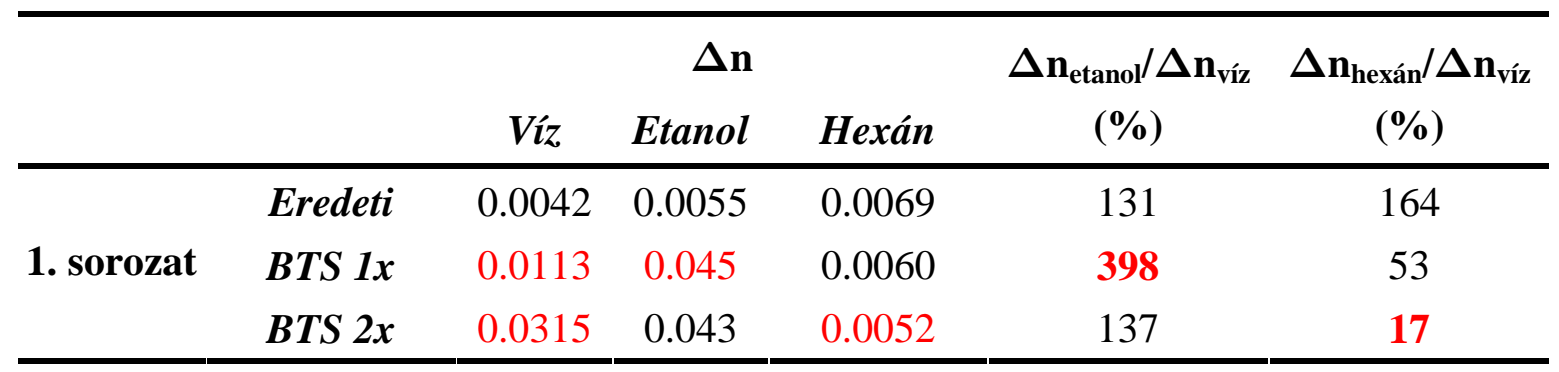

Az alábbi oszlopdiagramon foglaltam össze a butiltriklórszilánnal való módosítás eredményeit, a második minimum helyen mért adatokra szorítkozva.

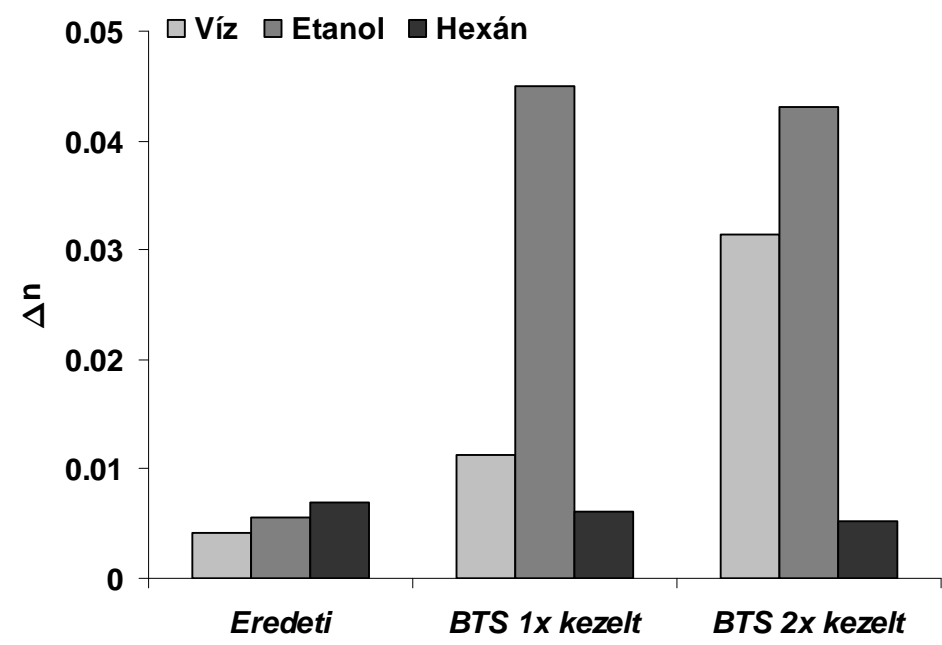

50. ábra Törésmutató változások 20 kettösrétegü kezeletlen, BTS-sel egyszer kezelt és BTS-sel kétszer kezelt $\mathrm{ZnO}_{2} / P S S$ mintán, víz-, etanol- és hexán göz jelenlétében $p_{r}=0.5$ relatív göznyomáson

\subsection{4. $\mathrm{ZnO}_{2} / \mathrm{PSS}$ film felületmódosítása oktántiollal borított nanoarany részecskékkel}

A második méréssorozatban oktántiollal borított nanoarany $0.01 \%$-os diszperziójából való felcseppentéssel végeztem el a módosítást. Ismeretes, hogy az alkiltiol vegyületek hosszú szénláncai hidrofobizálják a felületet, ezáltal kedvezményezetté válik a hasonló kémiai sajátságú anyagok (pl. toluol, hexán, szén-tetraklorid stb.) adszorpciója [115]. Az alkiltiolok tiolcsoportja (-SH) kovalens kötés kialakítására képes a nanoarany felületén, így az ilyen részecskék permanens bevonatot képeznek a félvezető/polimer hibrid vékonyréteg felületén. 
További előnye a tiollal borított nanoarany alkalmazásának, hogy kis részecskeméretéből adódóan képes lehet a felületen lévő „durva” pórusokat eltömíteni. Az oktántiollal módosított arany nanorészecskékről TEM felvételt készítettem, ez az 51. ábrán látható. A Brustszintézissel előállított nanoarany részecskék átlagos átmérője $2 \mathrm{~nm}$.

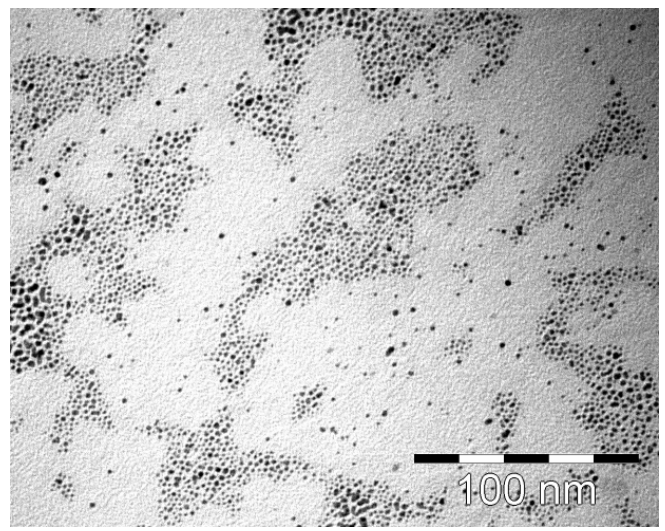

51. ábra Az oktántiollal módosított arany nanorészecskékröl készült TEM felvétel

UV-látható reflexió spektroszkópiával rögzítettem az eredeti 20 kettősréteg számú $\mathrm{ZnO}_{2} / \mathrm{PSS}$, és az egyszeres ill. kétszeres mennyiségü felületmódosító szerrel kezelt hibrid felületéről visszaverődő fény reflexió spektrumait (52. ábra). Az eredeti film spektrumán egy minimumhely és egy maximum hely figyelhető meg a 400-800 nm hullámhossz tartományban. Mindkét felületmódosítás alkalmával ca. 20-40 nm eltolódást figyelhetünk meg a nagyobb hullámhosszak irányába Ezek pontos értékeit a 8. táblázatban foglaltam össze.

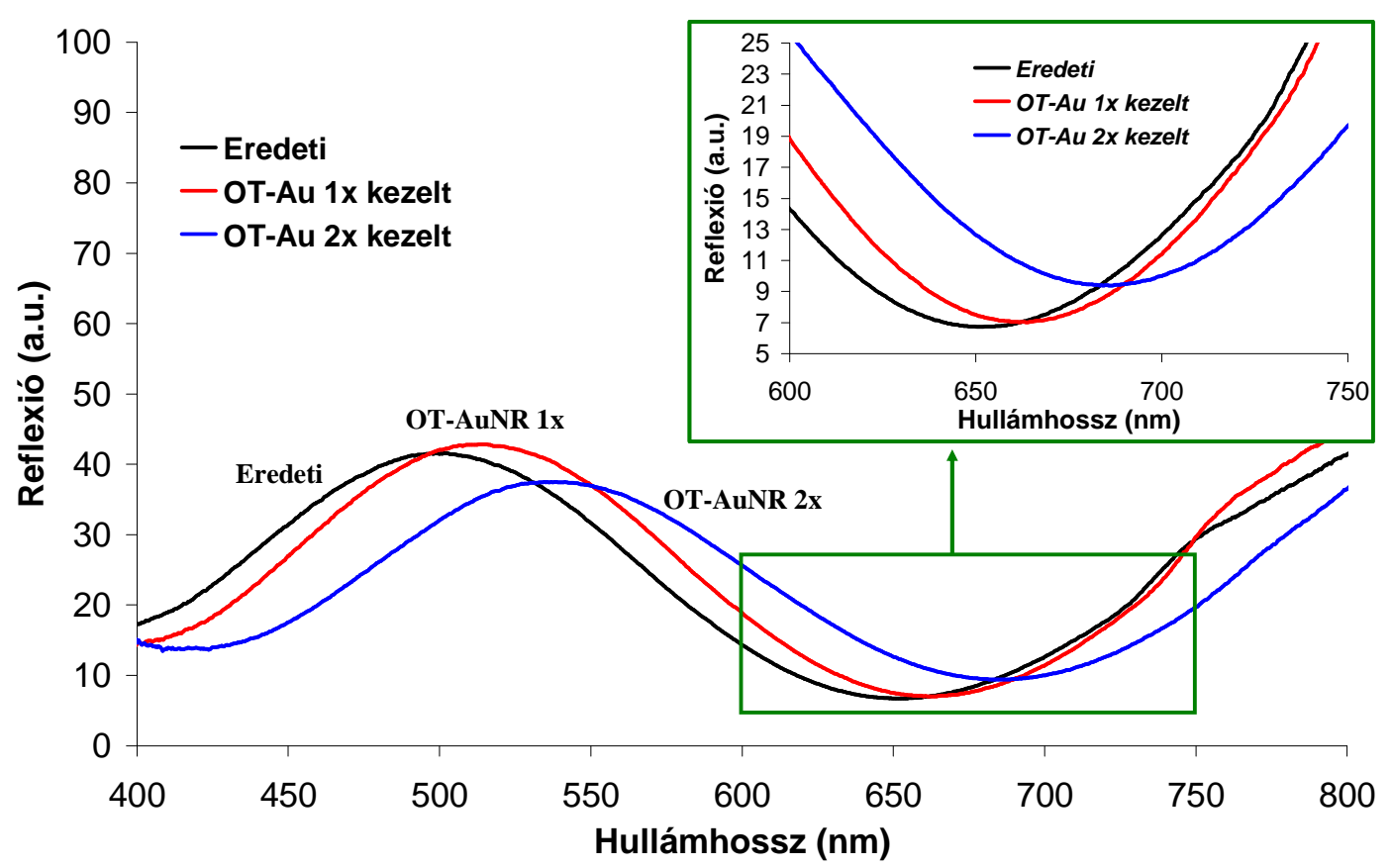

52. ábra Az eredeti (kezeletlen) és az oktántiollal borított arany nanorészecskékkel egyszer ill. kétszer kezelt, 20 kettösréteg számú $\mathrm{ZnO}_{2} / \mathrm{PSS}$ hibrid vékonyrétegek reflexiós spektrumai 
Meghatároztam a vékonyrétegek rétegvastagságát (d), amely 495 nm-nek adódott. Feltételeztem, hogy felületmódosítás során a rétegvastagság egy arany nanorészecskékből álló monoréteggel, azaz 2 nanométerrel növekszik, így $d=495$, 497 és $499 \mathrm{~nm}$ értékek mellett határoztam meg az eredeti és az egyszer ill. kétszer felületkezelt filmek törésmutatóját. Az eredeti minta törésmutatója 1.29-1.265 értékek közt változik a 400-800 nm hullámhossz tartományban, az oktántiollal borított nanoarannyal egyszeresen ill. kétszeresen kezelt vékonyrétegek megnövekedett törésmutatója pedig rendre 1.311-1.286 ill. 1.343-1.318 tartományban van (53. ábra).

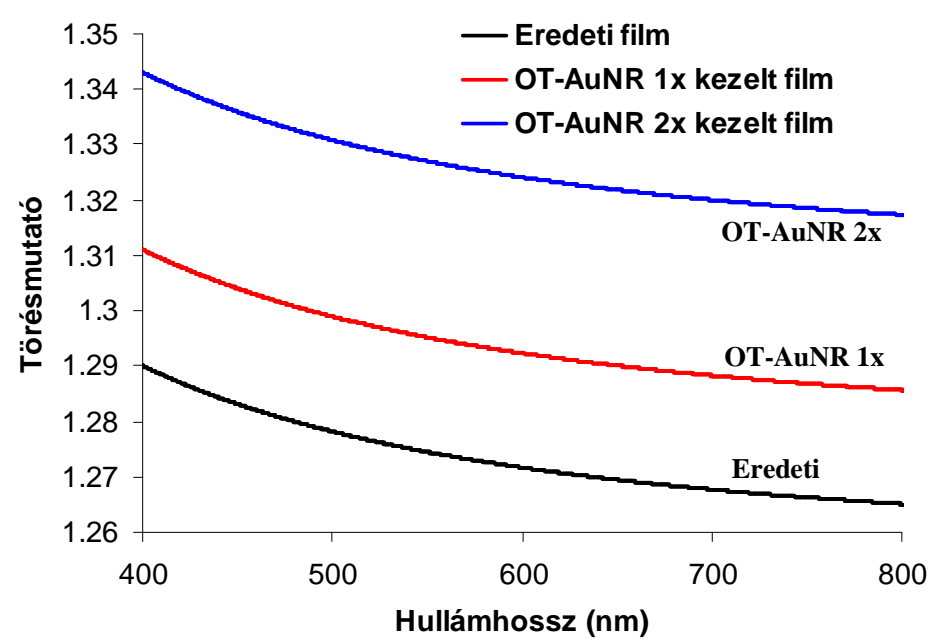

53. ábra Az eredeti (kezeletlen) és az oktántiollal borított arany nanorészecskékkel egyszer ill. kétszer kezelt, 20 kettösréteg számú $\mathrm{ZnO}_{2} / \mathrm{PSS}$ hibrid vékonyrétegek törésmutatója a hullámhossz függvényében a 400-800 nm tartományban

8. táblázat $A z$ eredeti (kezeletlen) és az oktántiollal borított nanoarannyal (OT-AuNR) egyszer ill. kétszer kezelt, 20 kettösréteg számú $\mathrm{ZnO}_{2} / P S S$ hibrid vékonyrétegek szélsőértékeihez tartozó hullámhosszak

\begin{tabular}{cccc}
\hline & $\begin{array}{c}\text { 1. maximum helye } \\
(\mathbf{n m})\end{array}$ & $\begin{array}{c}\text { 2. minimum helye } \\
(\mathbf{n m})\end{array}$ & Törésmutató \\
\cline { 2 - 4 } $\begin{array}{c}\text { Eredeti } \mathrm{ZnO} \mathrm{O}_{2} / \mathrm{PSS} \\
\text { hibrid film }\end{array}$ & 498 & 653 & $1.29-1.265$ \\
\hline $\begin{array}{c}\text { OT-AuNR-rel 1x kezelt } \\
\mathrm{ZnO} \mathrm{O}_{2} / \text { PSS hibrid film }\end{array}$ & 514 & 664 & $1.311-1.286$ \\
\hline $\begin{array}{c}\text { OT-AuNR-rel 2x kezelt } \\
\mathrm{ZnO} \mathrm{O}_{2} \text { /PSS hibrid film }\end{array}$ & 542 & 688 & $1.343-1.318$ \\
\hline
\end{tabular}


Az oktántiollal módosított nanoarannyal való felületkezelés elsődleges célja a vékonyréteg hidrofobizálása volt, így ebben a kísérletsorozatban víz és hexán gőz adszorpcióját hasonlítottam össze. A mérési adatok részletes ismertetése ez esetben is a függelékben található (3. számú függelék), ebben a szakaszban csak a végeredmények ismertetésére és diszkussziójára szorítkozom.

A méréseket az eredeti és felületkezelt minták reflexió spektrumainak második minimum helyén végeztem el (a 400-800 nm tartományban csak ez található teljes egészében). Az 54. ábrán láthatók a víz- és a hexán gőzre vonatkozó eredmények. Víz esetében az eredeti és az egyszeresen kezelt mintán mért törésmutató változás tekintetében nincs különbség a $p_{r}=$ 0-0.5 tartományban. $p_{r}=0.6$ relatív gőznyomás felett tapasztalható, hogy a görbe eredeti mintán felívelő szakasza az egyszer kezelt esetben „letörik”. A második felületkezelés után pedig a vízgőz adszorpciója teljesen jelentéktelenné válik, főként a hexán által okozott törésmutató változáshoz mérten. Hexán esetén is azt figyelhetjük meg, hogy az első felületmódosítás során csak kismértékü változás történik, míg a második kezelés után növekszik ugrásszerủen az adszorbeált gőz mennyisége.

Véleményem szerint ezen jelenségekre a magyarázat a következő: az első felületmódosítás után a felület csupán részlegesen borított oktántiolos nanoarannyal, így a vízmolekulák számára továbbra is lehetséges átjárás a film belseje felé, de a felületen megszünik a felhalmozódás lehetősége (ezért a görbén a letörés), amellett, hogy maradnak szabad kötőhelyek. Ezzel párhuzamosan a hexán molekulák számára újabb felületi kötőhelyek keletkeznek. A második kezelés után viszont az oktántiollal borított nanoarany felhalmozódik a vékonyréteg felületén, így a vízmolekulák számára sem az átjárás, sem a felületi adszorpció nem lehetséges többé, ezért a drasztikus csökkenés. Ezzel szemben a hexán molekulák továbbra is kötődnek a nanoarany felületén (54. ábrán $O T$-AuNR $1 x$ és $O T$-Au-NR $2 x$ görbék hexán estében a $p_{r}=0$-0.2 szakaszon azonosan futnak), valamint az egymásra rakódott arany részecskék közti - oktántiol miatt hidrofób - pórusokban nagy mennyiségben fel is halmozódnak, ez magyarázza az ugrásszerü növekedést (55. ábra). 

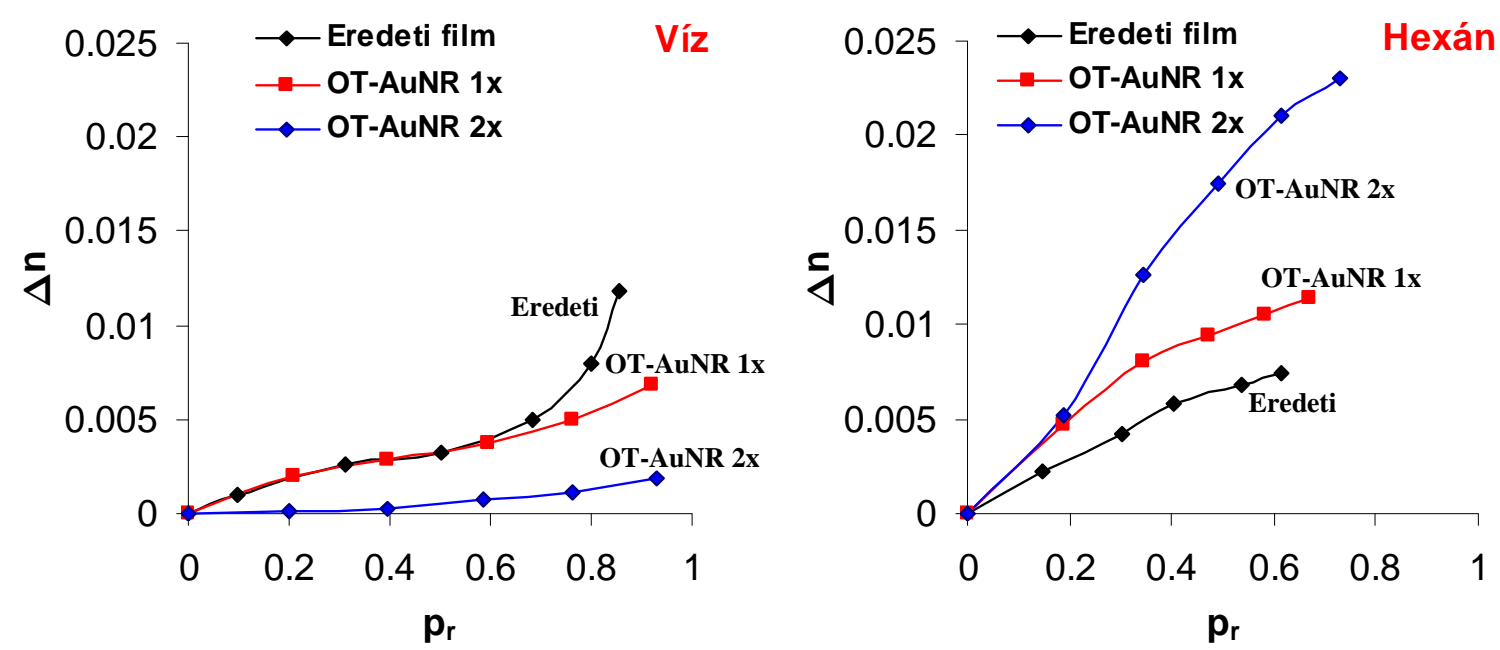

54. ábra Viz- és hexán gőz adszorpciója által okozott törésmutató változás a relatív göznyomás függvényében eredeti (kezeletlen) és oktántiollal borított arany nanorészecskékkel egyszer ill. kétszer kezelt, 20 kettösréteg számú $\mathrm{ZnO}_{2} / \mathrm{PSS}$ hibrid vékonyrétegeken

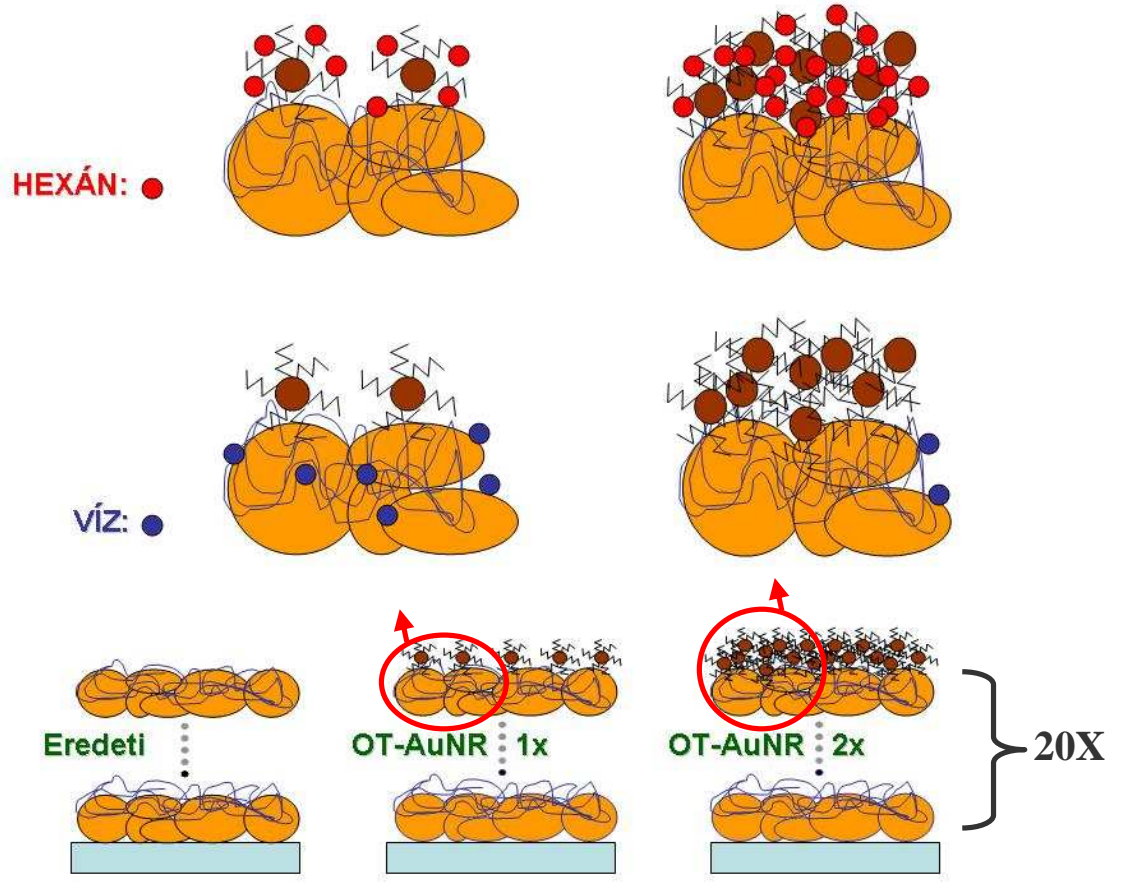

55. ábra Az oktántiollal borított nanoarannyal való felületmódosítás egy lehetséges modellje

Az oktántiollal borított nanoarannyal való felületmódosítás eredményeit összefoglalóan az 56. ábrán adtam meg. Az oszlopdiagramon kitünően követhető a vékonyréteg hidrofobitásának növekedése a felületmódosítások során, melynek kezdetén (az eredeti mintán) a hexán:víz által okozott törésmutató változás aránya $2: 1$, a második módosítás után pedig 25:1. 


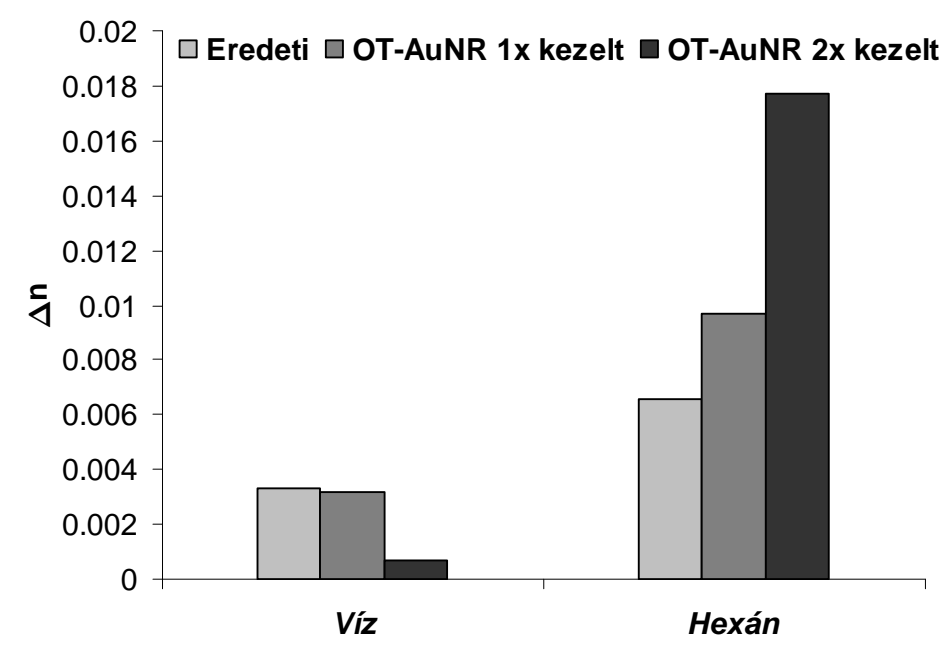

56. ábra Törésmutató változások 20 kettösrétegü kezeletlen, OT-AuNR -rel egyszer és kétszer kezelt $\mathrm{ZnO}_{2} / \mathrm{PSS}$ mintán, víz- és hexán göz jelenlétében $p_{r}=0.5$ relatív göznyomáson

9. táblázat Víz-és hexán adszorpció által okozott törésmutató változás az eredeti és oktántiollal borított nanoarannyal egyszer ill. kétszer kezelt 20 kettösrétegü $\mathrm{ZnO}_{2} / \mathrm{PSS}$ vékonyréteg reflexió spektrumának második minimumhelyén.

\begin{tabular}{|c|c|c|c|}
\hline & \multicolumn{2}{|c|}{$\Delta n$} & \multirow{2}{*}{$\begin{array}{c}\Delta \mathbf{n}_{\text {hexán }} / \Delta \mathbf{n}_{\text {víz }} \\
(\%)\end{array}$} \\
\hline & Viz & Hexán & \\
\hline Eredeti & 0.0033 & 0.0066 & 200 \\
\hline$O T-A u N R 1 x$ & 0.0032 & 0.0097 & 303 \\
\hline$O T-A u N R 2 x$ & 0.0007 & 0.0177 & 2529 \\
\hline
\end{tabular}

\subsubsection{A törésmutató változás kalibrációja kvarckristály mikromérleggel}

Munkám során kísérletet tettem a $\mathrm{ZnO}_{2} / \mathrm{PSS}$ hibrid vékonyrétegek épülésének részletes figyelemmel követésére. Ennek egyik oka a linearitás ellenőrzése, másik oka pedig a gőzök adszorpciója során a törésmutató változás és a tömegegységre vonatkoztatott adszorbeált tömeg (ng göz/ $\mu g$ film egységben) megbecslése. Ennek során kvarckristály mikromérleggel dolgoztam, melynek arany bevonatú felületére építettem a rétegeket, miközben minden egyes komponens 10 perces adszorpciója, valamint a film ioncserélt vízzel való öblítése és nitrogénnel való szárítása után légszáraz állapotban megmértem a kialakult film fajlagos (felületegységre vonatkoztatott) tömegét. Ennek eredményét a 58. ábra tartalmazza. Látható, hogy a cink-peroxid járuléka a fajlagos tömeghez átlagosan $2.8 \pm 0.2 \mu \mathrm{g} / \mathrm{cm}^{2}$, a polimeré pedig 
$0.15 \pm 0.02 \mu \mathrm{g} / \mathrm{cm}^{2}$ minden egyes kettősrétegben. Előbbit szemlélteti a 57. ábrán látható képernyő-fénykép, melyet a vékonyréteg $\mathrm{ZnO}_{2}$ diszperzióba való merítésekor rögzítettem.

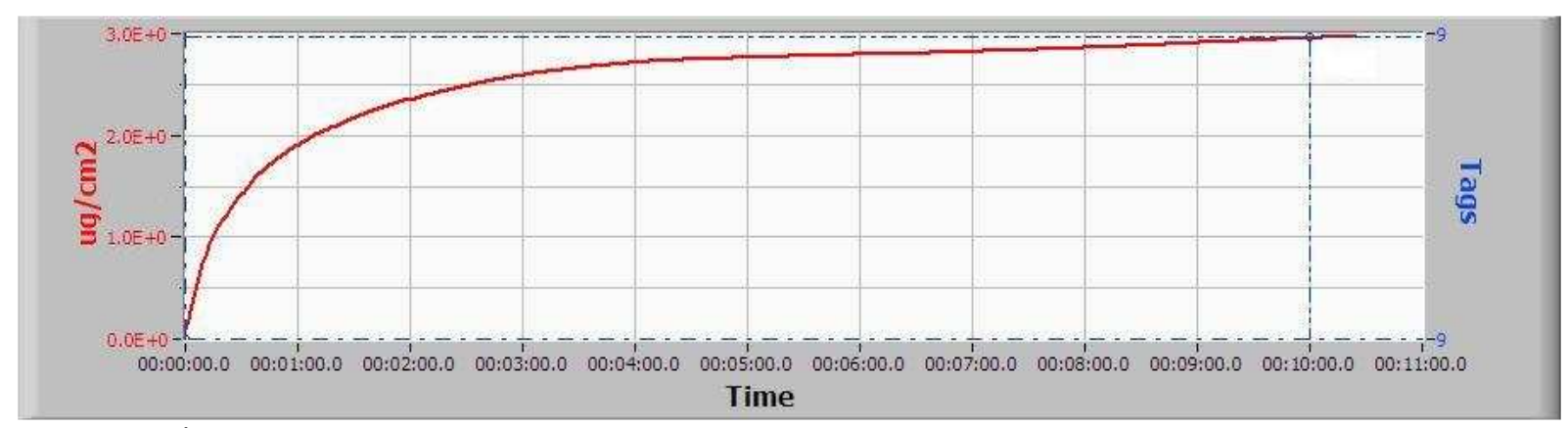

57. ábra $\mathrm{ZnO}_{2}$ adszorpciójának kvarckristály mikromérleggel való követése az idö függvényében (képernyö-fénykép)

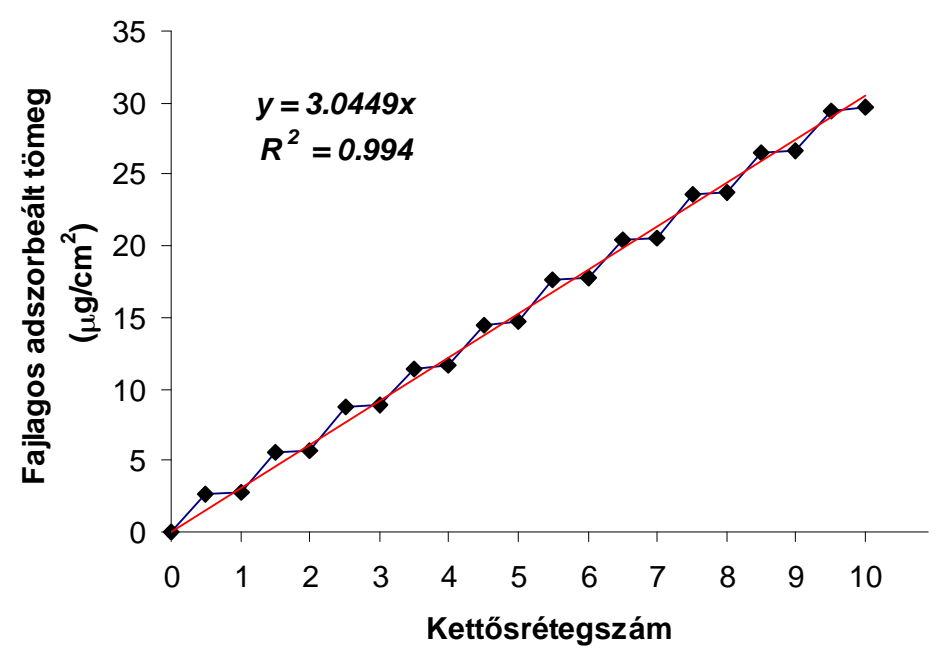

58. ábra 10 kettösrétegü $\mathrm{ZnO}_{2} / P S S$ vékonyréteg készitésének lépései kvarckristály mikromérleggel követve, annak arany felületén

A 4.4.2 és 4.4.3 fejezetekben bemutatott mérések során, amennyiben feltételezzük, hogy a vékonyrétegek azonos mennyiségü szervetlen és szerves komponenst tartalmaznak kettősrétegenként, mint az 58. ábrán bemutatott hibrid film, abban esetben meghatározhatjuk a gőzök adszorbeált mennyiségét a film tömegegységére vonatkoztatva. A 10 kettősrétegü film össztömege $29.65 \mu \mathrm{g}$ felületegységenként, így a továbbiakban feltételeztem, hogy a 20 kettősrétegü eredeti film össztömege $59.3 \mu \mathrm{g} \mathrm{cm}^{2}$-enként, s ezzel az értékkel végeztem számításaimat. A butiltriklórszilánnal $\left(M_{w}=191.57 \mathrm{~g} / \mathrm{mol}\right)$ módosított filmek esetén, azt vettem figyelembe, hogy $10 \mu \mathrm{L} 0.01 \mathrm{M}$ koncentrációjú hexános oldatot terítettem szét közel $10 \mathrm{~cm}^{2}$ területen, ez egy módosítás során 1.9, két kezelés után pedig 3.8 $\mu \mathrm{g} / \mathrm{cm}^{2}$-rel növeli a vékonyréteg fajlagos tömegét $\left(\Sigma=61.2 \mathrm{ill} 63.1 \mu \mathrm{g} / \mathrm{cm}^{2}\right)$. Ugyanezen 
gondolatmenettel számítva a nanoarany $(c=0.01 \%)$ fajlagos hozzájárulását a film tömegéhez 0.1 ill. $0.2 \mu \mathrm{g} / \mathrm{cm}^{2}$ az eredmény $\left(\Sigma=59.4\right.$ ill. $\left.59.5 \mu \mathrm{g} / \mathrm{cm}^{2}\right)$.

Ahhoz azonban, hogy a gőzök fajlagos adszorbeált tömegét meghatározzuk, ismernünk kell a törésmutató változás és a felületegységenként adszorbeált gőzmennyiség közti összefüggést. A következőkben ennek meghatározására tettem kísérletet.

Az 59.a és b ábrákat felületesen szemlélve is igen jó egyezés tapasztalható a 2 kettősrétegü $\mathrm{ZnO}_{2} / \mathrm{PSS}$ filmen QCM -mel mért hexán és etanol gőz adszorpció, valamint a 20 kettősrétegü $\mathrm{ZnO}_{2} / \mathrm{PSS}$ vékonyrétegen mért törésmutató változás közt (etanol és hexán adszorpció során). A $p_{r}=0.5$ relatív gőznyomáson leolvasott értékek hexán esetén $\Delta \mathrm{n}=0.0069$ ill. $\Delta \mathrm{m}=5.95 \mathrm{nmol} / \mathrm{cm}^{2}$, etanol esetén pedig $\Delta \mathrm{n}=0.0055$ ill. $\Delta \mathrm{m}=4.7 \mathrm{nmol} / \mathrm{cm}^{2} . \mathrm{A} \Delta \mathrm{m} / \Delta \mathrm{n}$ arány számértéke rendre 862.31 ill. 854.54, melyek egymástól alig eltérő értékek ( 1\%). Ezek alapján jó okunk van feltételezni, hogy a törésmutató változás és a fajlagos adszorbeált mennyiség közt kalibrációval kis hibával járó összefüggés található.
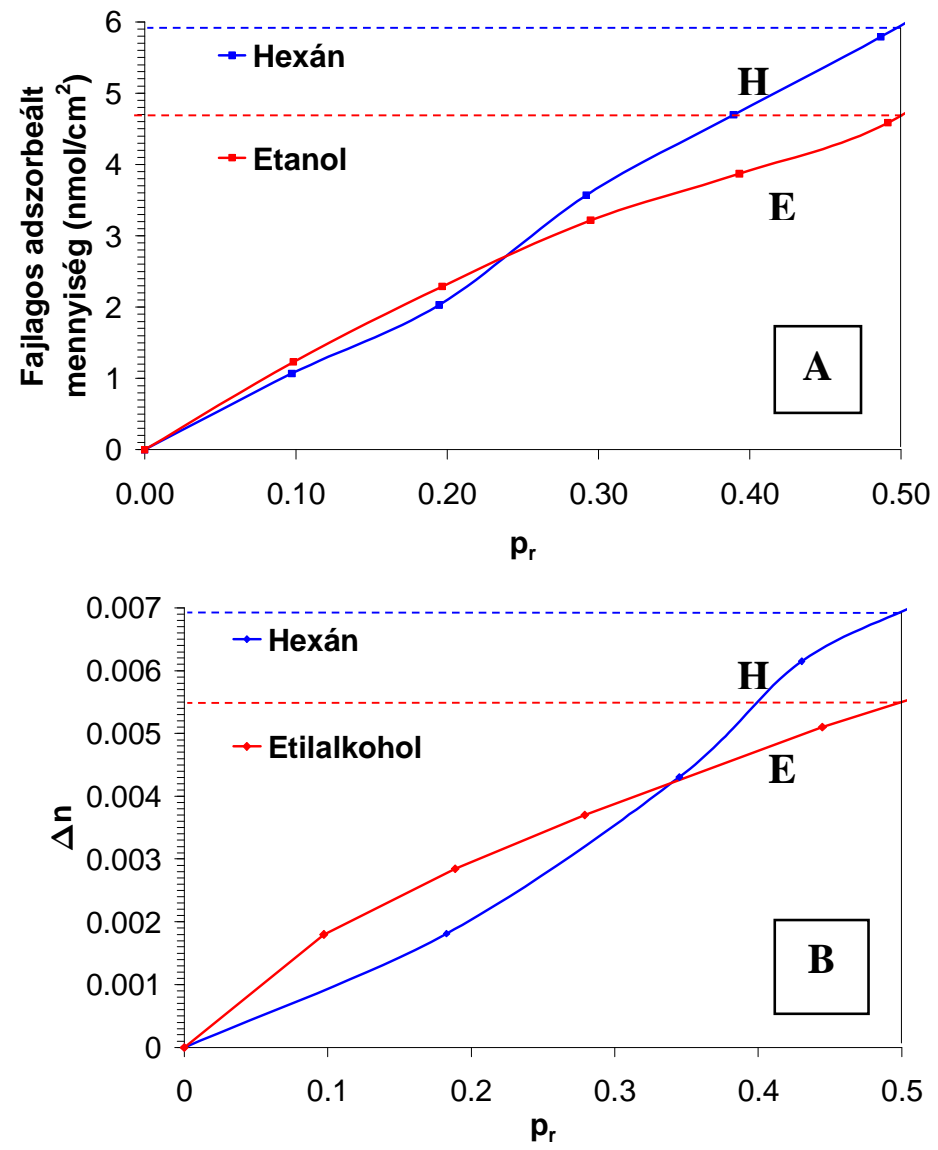

59. ábra 2 kettősrétegü $\mathrm{ZnO}_{2} / P S S$ filmen QCM-mel mért hexán és etanol göz adszorpció, valamint a 20 kettösrétegü $\mathrm{ZnO}_{2} / P S S$ vékonyrétegen mért törésmutató változás (etanol és hexán adszorpció során) /korábban 43.a. és 48. ábral 
A 58. ábrán bemutatott 10 kettősrétegü $\mathrm{ZnO}_{2} / \mathrm{PSS}$ film építése során minden elkészített kettősrétegen megmértem hexán ill. etanol gőz adszorpcióját kalibráció céljából. Ennek eredménye a 60. és 61. ábrán láthatóak 2,3,4 és 5 kettősréteg esetén, $p_{r}=0-0.5$ tartományban. Az összehasonlíthatóság miatt a korábbiakban is $p_{r}=0.5$ értéknél adtam meg a törésmutató változások értékeit, így a kalibrációhoz is ezen a relatív gőznyomás értéken olvastam le az értékeket. Mindkét esetben egy nem nulla tengelymetszetű egyenest kaptam (62. ábra). Ennek oka feltételezésem szerint az, hogy a gőzök adszorpciója mind a részecskék pórusaiban, mind a polimerrel borított felületén végbemegy. Az 1 kettősrétegü film esetén rendelkezésre áll 1 részecske réteg, valamint egy polimerrel borított felület. 2 kettősréteg esetén az előbbi polimerrel borított felületet elfoglalják a $\mathrm{ZnO}_{2}$ részecskék (hiszen ez az LbL technika alapja), ezek a kötőhelyek megszünnek, így a gőzök számára a továbbiakban 2 részecske réteg és egy polimerrel borított felület marad. 3,4... stb. kettősréteg szám esetén így 3,4 ... részecske réteg és egy legfelső, polimerrel borított felület áll rendelkezésre a gőzök adszorpciójához (63. ábra).

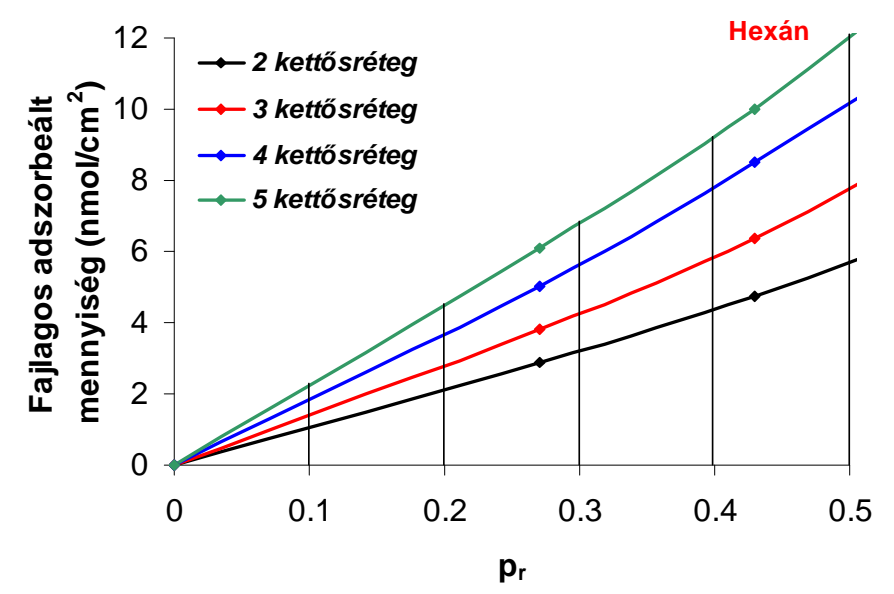

60. ábra 2,3,4, és 5 kettösréteg számú $\mathrm{ZnO}_{2} / P S S$ hibrid vékonyrétegen mért hexán adszorpció

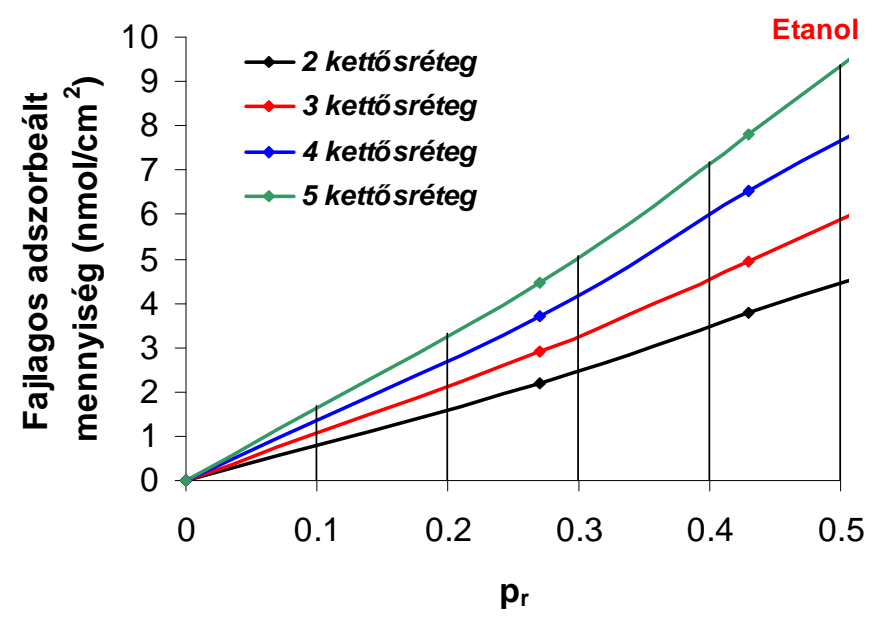

61. ábra 2,3,4, és 5 kettősréteg számú $\mathrm{ZnO}_{2} / \mathrm{PSS}$ hibrid vékonyrétegen mért etanol adszorpció 

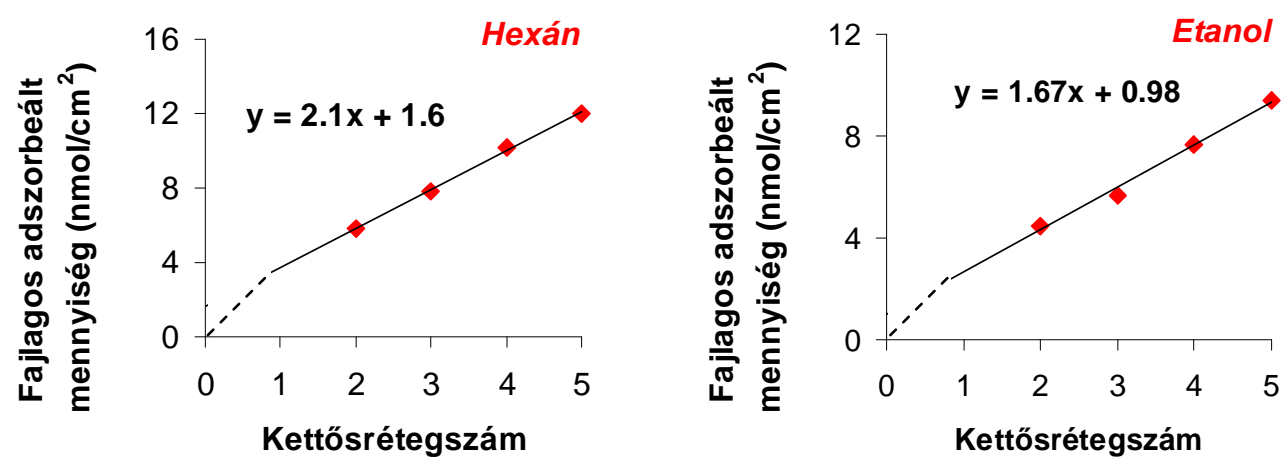

62. ábra 2,3,4, és 5 kettösréteg számú $\mathrm{ZnO}_{2} / P S S$ hibrid vékonyrétegen mért hexán és etanol adszorpcióhoz tartozó kalibrációs görbék $p_{r}=0.5$ relatív göznyomáson

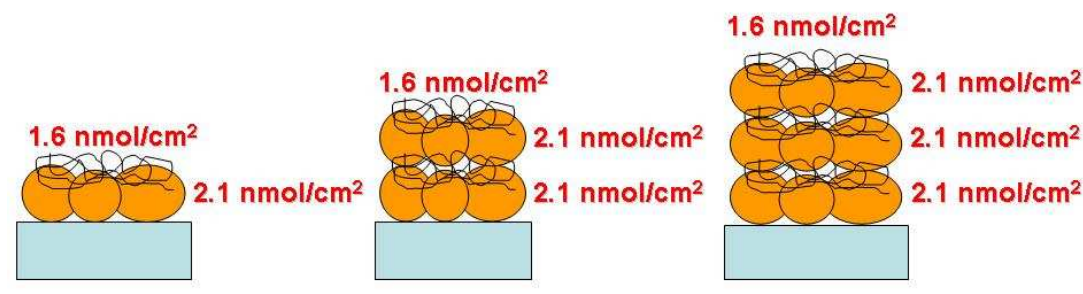

63. ábra A nem-zéró tengelymetszet egy lehetséges magyarázata (hexán kalibráció példáján)

Ezen megfontolással a 20 kettősréteg számú $\mathrm{ZnO}_{2} / \mathrm{PSS}$ hibrid vékonyrétegen, hexán adszorpció során mért $\Delta \mathrm{n}=0.0069$ törésmutató változáshoz tartozó fajlagos adszorbeált anyagmennyiség $43.6 \mathrm{nmol} / \mathrm{cm}^{2}$, az etanol adszorpció során mért $\Delta \mathrm{n}=0.0055$ törésmutató változáshoz tartozó fajlagos adszorbeált anyagmennyiség pedig $34.38 \mathrm{nmol} / \mathrm{cm}^{2}$. A két mennyiség között egy arányossági tényező, $k=0.000157 \mathrm{nmol}^{-1} \mathrm{~cm}^{2}$ értékü konstans teremt kapcsolatot. A fenti, $0.000157 \mathrm{nmol}^{-1} \mathrm{~cm}^{2}$ kalibrációs konstans, valamint a 20 kettősrétegü film közel $60 \mu \mathrm{g} / \mathrm{cm}^{2}$ felületegységre vonatkoztatott tömegét felhasználva adhatjuk meg a 4.4.2. és 4.4.3. fejezetekben nyert eredményeinket felületegységre vonatkoztatott anyagmennyiség $\left(\mathrm{nmol} / \mathrm{cm}^{2}\right)$, ill. a film tömegére vonatkoztatott mennyiség $(\mathrm{ng} / \mu \mathrm{g})$ formájában.

Az ábrákról és a táblázatból kiolvasva megállapíthatjuk, hogy a kezeletlen minták néhány tíz nmol nagyságrendben adszorbeálnak $1 \mathrm{~cm}^{2}$ felületegységenként, ill. néhány $10 \mathrm{ng}$ nagyságrendben $\quad 1 \quad \mu g$ film tömegegységenként. Ettől nagymértékben eltérnek a felületmódosított minták bizonyos esetekben: a butiltriklórszilánnal módosított vékonyréteg a $215.43 n g / \mu g$ adszorbeált etanol mennyiséggel közel egy nagyságrenddel, az oktántiollal 
borított arany nanorészecskékkel módosított hibrid a 162.95 ng/ $\mu g$ adszorbeált hexán mennyiséggel pedig két nagyságrenddel múlja felül a vízgőz adszorpcióját.

Megállapítottam tehát, hogy a butiltriklórszilán és az oktántiollal módosított nanoarany kiválóan alkalmasak etilalkohol ill. hexán gőzre való specifikus érzékenység nagyságrendekkel való növelésére.
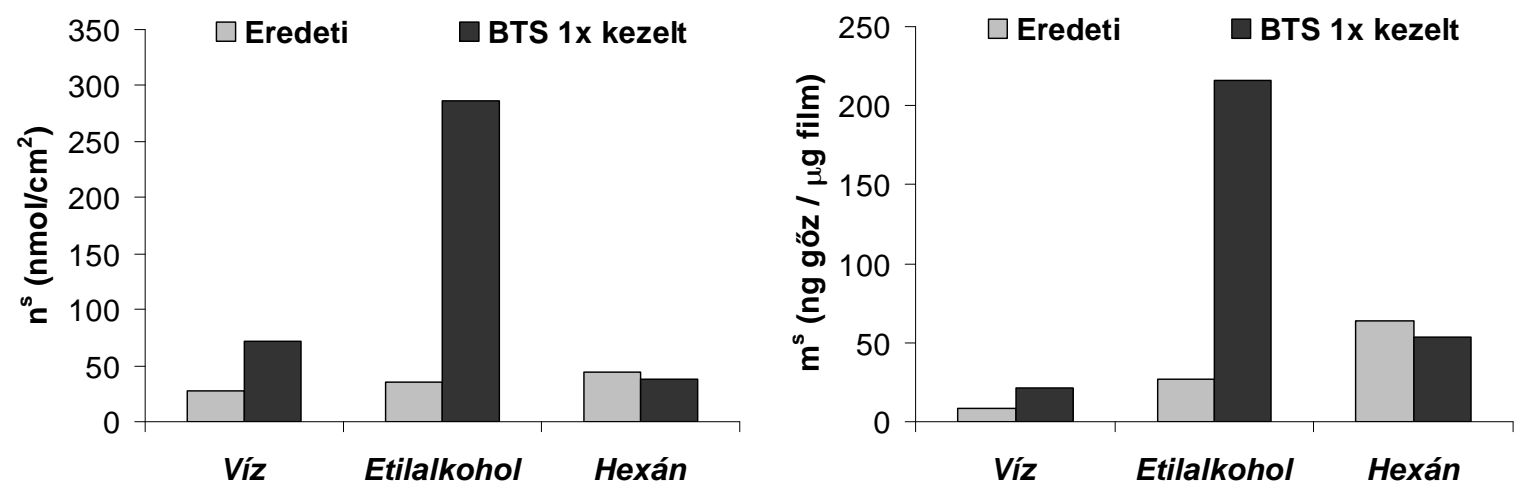

64. ábra Víz-, etanol- és hexán göz adszorpciója eredeti (kezeletlen) és BTS -nal egyszer kezelt, 20 kettösréteg számú $\mathrm{ZnO}_{2} / P S S$ hibrid vékonyrétegen, $p_{r}=0.5$ relatív göznyomáson
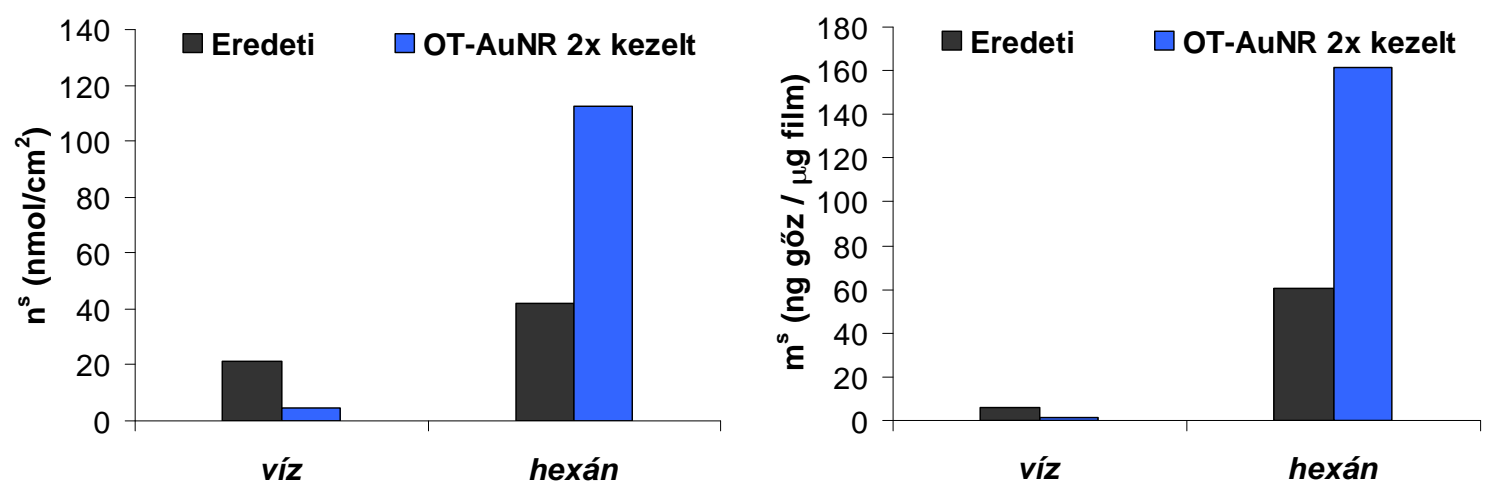

65. ábra Víz- és hexán göz adszorpciója eredeti (kezeletlen) és OT-AuNR-kel kétszer kezelt, 20 kettösréteg számú $\mathrm{ZnO}_{2} / P S S$ hibrid vékonyrétegeken $p_{r}=0.5$ relatív göznyomáson

10. táblázat Eredeti és butiltriklórszilánnal egyszer ill. oktántiolos nanoarannyal kétszer kezelt 20 kettösrétegü $\mathrm{ZnO}_{2} / P S S$ hibrid vékonyrétegeken fajlagosan adszorbeált víz-, etanolés hexán anyagmennyiségek ill. tömegek

\begin{tabular}{|c|c|c|c|c|c|c|c|}
\hline & & \multicolumn{3}{|c|}{$\mathbf{n}^{\mathrm{s}}\left(\mathbf{n m o l} / \mathrm{cm}^{2}\right)$} & \multicolumn{3}{|c|}{$m^{s}$ (ng gőz / $\mu$ g film) } \\
\hline & & Viz & Etanol & Hexán & Viz & Etanol & Hexán \\
\hline \multirow{2}{*}{ 1. sorozat } & Eredeti & 26.75 & 35.03 & 43.94 & 8.12 & 27.17 & 63.73 \\
\hline & BTS 1x & 71.97 & 286.62 & 38.21 & 21.16 & 215.43 & 53.70 \\
\hline \multirow{2}{*}{ 2. sorozat } & Eredeti & 21.01 & - & 42.03 & 6.38 & - & 60.96 \\
\hline & $O T-A u N R 2 x$ & 4.46 & - & 112.73 & 1.35 & - & 162.95 \\
\hline
\end{tabular}




\subsubsection{A törésmutató változás és adszorptívum tömegtörtje közti összefüggés}

A 4.4.5. fejezetben meghatároztam az összefüggést a törésmutató változás és a fajlagosan adszorbeált anyagmennyiség közt $p_{r}=0.5$ relatív gőznyomáson, ezzel lehetőség nyílt a korábban nyert kvalitatív eredményeimet $(\Delta \mathrm{n})$ kvantitatív formában $\left(\mathrm{n}^{\mathrm{s}}\left[\mathrm{nmol} / \mathrm{cm}^{2}\right]\right)$ megadni. A két mennyiség közti kapcsolatot egy $0.000157 \mathrm{nmol}^{-1} \mathrm{~cm}^{2}$ konstans teremtette meg. A kalibrációt más relatív gőznyomásokon is elvégezve egy olyan görbét kapunk eredményül, melynek meredeksége szélesebb tartományban alkalmas jellemezni az adszorbeált anyagmennyiség és a törésmutató változás közti kapcsolatot.

A kalibrációt elvégeztem $p_{r}=0.1,0.2,0.3,0.4$ és 0.5 értékeken. Az eredmény öt-öt különböző kalibrációs egyenes (66. ábra), amelyek extrapolációjából nyertem a 20 kettősréteg számra vonatkozó fajlagos adszorbeált mennyiség értékeket $\left(n^{s}\right)$, melyekből a moláris tömeg $\left(M_{w}\right)$, valamint a film fajlagos tömegének $\left(m_{f}\right)$ ismeretében meghatároztam az ún. tömegtörtet:

$$
\frac{n^{s} \cdot M_{w}}{n^{s} \cdot M_{w}+m_{f}}=\frac{m^{s}}{m^{s}+m_{f}}
$$

Végül a tömegtörteket (az adott relatív gőznyomáson) ábrázoltam az egyes $p_{r}$ értékekhez tartozó törésmutató változások függvényében (67. ábra). Ennek eredményeképpen olyan egyeneseket kaptam, melyek megadják az egyes törésmutató változásokhoz tartozó tömegtörtek értékét az adott anyagra vonatkozóan. Etanol esetén ez a meredekség 4.6177, azaz a hibrid vékonyréteg törésmutatójának 0.001 -del való megváltozása esetén a tömegtört 0.00462 értékkel változik. Hexán esetén a meredekség 9.3203 (0.00932/0.001).
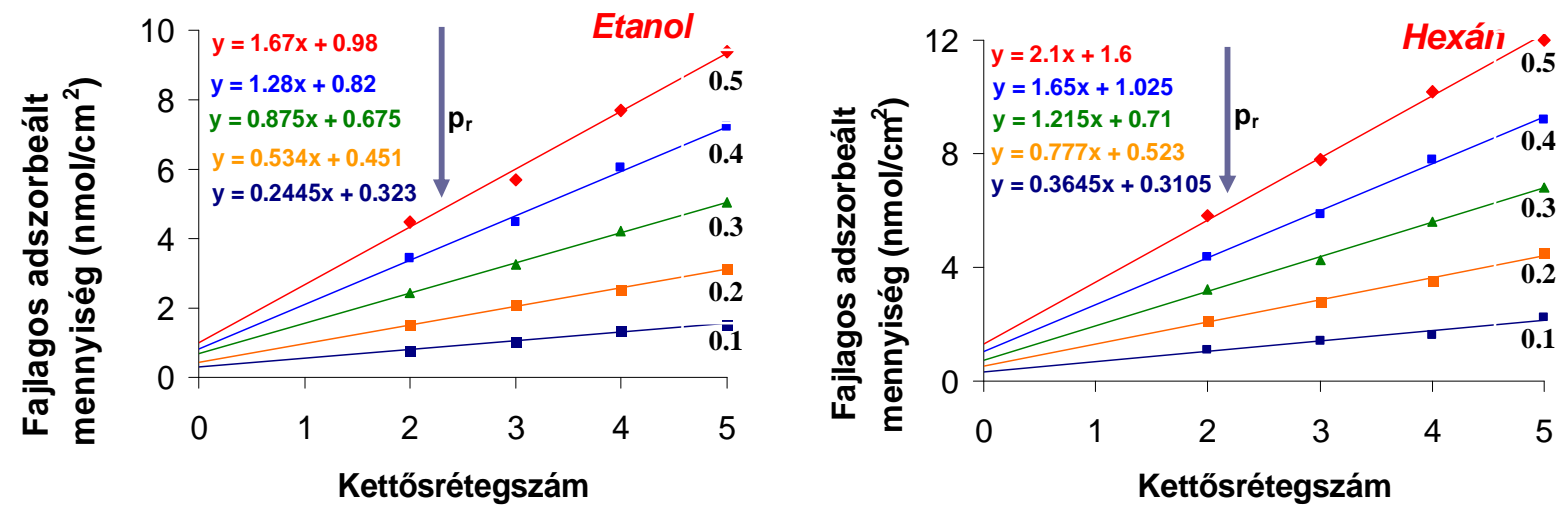

66. ábra 2,3,4, és 5 kettösréteg számú $\mathrm{ZnO}_{2} / P S S$ hibrid vékonyrétegen mért hexán és etanol adszorpcióhoz tartozó kalibrációs görbék $p_{r}=0.1-0.5$ relatív göznyomáson 


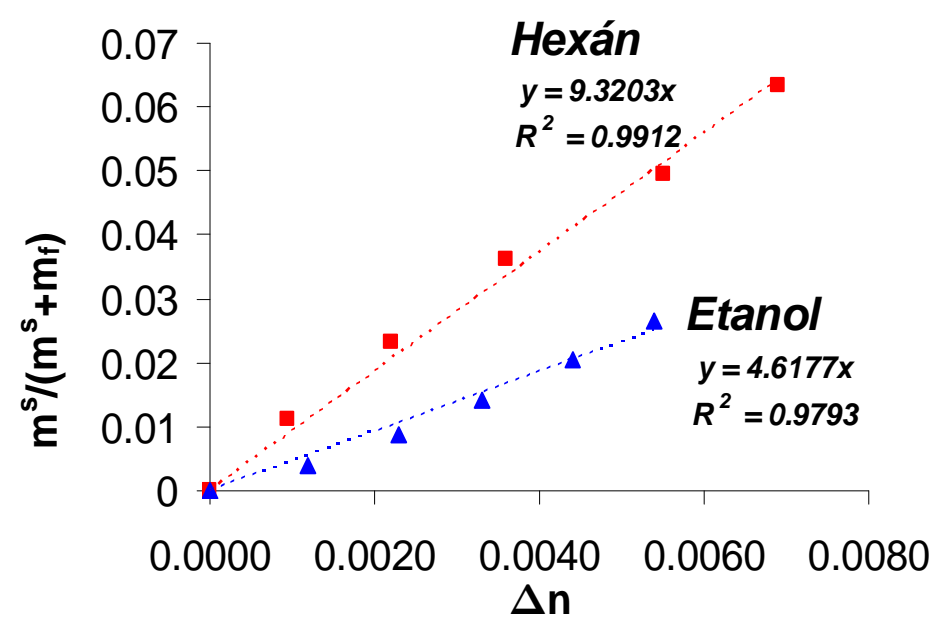

67. ábra Hexán és etilalkohol tömegtörtje a törésmutató változás függvényében 20 kettösrétegü $\mathrm{ZnO}_{2} / P S S$ filmen

11. táblázat A fajlagos adszorbeált anyagmennyiség, a törésmutató változás és a tömegtörtek különbözö $p_{r}$ értékek mellett, etanol és hexán esetén 20 kettösrétegü (kezeletlen) $\mathrm{ZnO}_{2} / \mathrm{PSS}$ hibrid vékonyrétegen

\begin{tabular}{|c|c|c|c|c|c|c|c|c|}
\hline & \multicolumn{2}{|c|}{$\begin{array}{c}\text { Fajlagos } \\
\text { adszorbeált } \\
\text { anyagmennyiség } \\
20 \text { kettősréteg } \\
\text { esetén }\left(\mathrm{nmol} / \mathrm{cm}^{2}\right)\end{array}$} & \multicolumn{2}{|c|}{$\Delta n$} & \multicolumn{2}{|c|}{$\begin{array}{c}\text { Tömegtört } \\
\left(\mathbf{x}_{1}\right)\end{array}$} & \multicolumn{2}{|c|}{$\begin{array}{c}\text { Az egyenes } \\
\text { meredeksége } \\
\left(\mathrm{x}_{1} / \Delta \mathrm{n}\right)\end{array}$} \\
\hline $\mathbf{p}_{\mathbf{r}}$ & Etanol & Hexán & Etanol & Hexán & Etanol & Hexán & Etanol & Hexán \\
\hline 0.1 & 5.203 & 7.6005 & 0.0012 & 0.00095 & 0.004036 & 0.011023 & & \\
\hline 0.2 & 11.131 & 16.063 & 0.0023 & 0.0022 & 0.008635 & 0.023295 & & \\
\hline 0.3 & 18.175 & 25.01 & 0.0033 & 0.0036 & 0.014099 & 0.036271 & 4.6177 & 9.3203 \\
\hline 0.4 & 26.42 & 34.025 & 0.0044 & 0.0055 & 0.020494 & 0.049345 & & \\
\hline 0.5 & 34.38 & 43.6 & 0.0054 & 0.0069 & 0.026669 & 0.063231 & & \\
\hline
\end{tabular}




\section{5. Összefoglalás}

“Nem akkor alkottál tökéleteset, ha már nem tudsz mit hozzátenni, hanem ha már nem tudsz mit elvenni belöle."

(Antoine de Saint-Exupéry)

Munkám során elsőként cink-peroxid nanorészecskéket szintetizáltam vizes diszperzióban. A cink-acetát-dihidrát vizes közegben történő fotolízise 15-60 nm átmérőjü $\mathrm{ZnO}_{2}$ nanorészecskék képződéséhez vezet, a szintézis során növekvő részecskemérettel. Vizsgáltam az előállított részecskék optikai és szerkezeti tulajdonságait, meghatároztam méretüket, tanulmányoztam termikus bomlásukat, valamint felületi töltésállapotukat. Magas hőmérsékletű hőkezelés során $\left(\mathrm{T}>210^{\circ} \mathrm{C}\right)$ a cink-peroxid fázisátalakuláson megy keresztül, és termikus bomlás következtében $\mathrm{ZnO}$ részecskék keletkeznek. A hőkezelés (200-800 $\left.{ }^{\circ} \mathrm{C}\right)$ során a krisztallitok mérete 15 nm -ről 60 nm -ig nőtt (Debye-Scherrer-egyenletből számítva).

A pozitív felületi töltésű $\mathrm{ZnO}_{2}$ részecskékből és a negatív felületi töltésủ kötőanyagokból (PSS, poli(sztirolszulfonát), mint makromolekula és Na-hektorit, mint rétegszilikát) ún. pórusos hibrid vékonyrétegeket állítottam elő bemerítéses (Layer-by-Layer, LbL) önrendeződő eljárással szilárd hordozó felületén. A $\mathrm{ZnO}_{2} / \mathrm{Na}$-hektorit filmek $400{ }^{\circ} \mathrm{C}$ fok hőmérsékleten történő kezelésével nyertem $\mathrm{ZnO}$ tartalmú rétegeket, a cink-peroxid termikus bomlása eredményeképpen. A vékonyrétegek építéséhez $0.85 \%(\mathrm{~g} / \mathrm{L})$ koncentrációjú $\mathrm{ZnO}_{2}$ szolt, $0.1 \%$ Na-hektorit szuszpenziót és $0.01 \%$ PSS oldatot használtam. A rétegalkotó komponensek koncentrációjának kiválasztásában döntő szerepet játszott a fajlagos felületi töltés meghatározása, melyhez áramlási potenciál mérést alkalmaztam annak érdekében, hogy a rétegek épüléséhez szükséges komponensek arányát optimalizálni tudjam. Kísérleteim során azt tapasztaltam, hogy a $0.005 \%$ koncentrációjú PSS oldatból és $0.05 \%$ konc. Na-hektorit szuszpenzióból (1:10 töltésarány mellett) készített rétegek felépülése vagy nem egyenletes (az azonos hullámhosszakon mért abszorbancia értékek nem lineárisan növekednek a rétegszámmal), vagy pedig a kívánt rétegszám előtt telítődött a rendszer, azaz megszünt az elektrosztatikus vonzóerő (a kötőanyag felöl), amely szükséges a rétegek alternáló egymásra épüléséhez. A $0.05 \%$ koncentrációjú PSS oldatból és 0.02 \% konc. Nahektorit szuszpenzióból (1:1 ill. 1:1.25 töltésarány mellett) készített rétegek esetében szintén az elektrosztatikus vonzás hiánya lépett fel túlzottan hamar (a cink-peroxid töltésének túlzott kompenzációja miatt), és/vagy a magas kötőanyag mennyiség miatt a rétegek rendezetlenül épültek, ezáltal átlátszatlanná váltak, erős fényszórással. $0.01 \%$ PSS oldatból ill. $0.1 \%$ 
Na-hektorit szuszpenzióból (1:5 töltésarány mellett) a rétegek egyenletesen, rendezetten, lineáris abszorbancia növekedéssel épültek, így megállapítottam, hogy az optimális töltésarány a cink-peroxid és a kötőanyag közt 1:5, munkám során ezért mindvégig ezt az arányt használtam. Vizsgáltam a filmek felépülését UV-látható abszorpciós ill. reflexiós spektrofotometriával és kvarckristály mikromérleg segítségével. A szerkezeti tulajdonságokat röntgen diffrakcióval, a morfológiát pedig atomerő mikroszkóppal és pásztázó elektronmikroszkóppal vizsgáltam. A félvezetőknél fellépő tiltott sáv (angolul „bandgap”) a nanorészecskéknél is megjelenik, és így a vékonyrétegekben is. Megállapítottam, hogy a cinkperoxid/Na-hektorit vékonyrétegek esetében a tiltott sáv energiája független marad a rétegek számától, értéke állandó $3.98 \mathrm{eV}$, mivel a szilikát lamellák közt (ún. szabályozott térben) interkalálódott nanorészecskék mérete nem változik meg. Ez a tulajdonság kalcinálás után jellemző lesz a $\mathrm{ZnO} / \mathrm{Na}$-hektorit filmekre is, de értéke a szerkezet megváltozása miatt $3.2 \mathrm{eV}$-ra csökken. Ezzel szemben a PSS gombolyagok (kezdetben) jó hatásfokkal stabilizálják sztérikusan a nanorészecskéket, és ez által méret kvantált $\mathrm{ZnO}_{2}$ részecskékböl álló rétegek képződnek a félvezető/polielektrolit hibrid rétegekben, ezért a magas $\mathrm{E}_{\mathrm{g}}$ érték $(4.12 \mathrm{eV})$. A rétegszám növekedésével ez a hatás gyengül, legvégül az egész hibrid vékonyréteg egyetlen $\mathrm{ZnO}_{2}$ aggregátumként látszik a beeső fény számára, így megszünik a méret kvantálási effektus $\left(\mathrm{E}_{\mathrm{g}}=3.76 \mathrm{eV}\right)$.

Célul tüztem ki az elkészített hibrid vékonyrétegek optikai tulajdonságainak mérésére és jellemzésére szolgáló módszerek kidolgozását, első sorban a rétegvastagságot és a törésmutatót illetően. Ez utóbbi fontossága abban rejlik, hogy gázok, gőzök jelenlétében a filmek reflexió spektruma a vörös színtartomány irányába tolódik el, a törésmutató növekedése miatt. Az irodalomban fellelhető módszerekkel ellentétben az általam kidolgozott technika nem a merőleges beesési szöghöz tartozó reflexió spektrum néhány adott pontjából határozza meg a törésmutató értékét, hanem analitikus görbék spektrumra történő illesztésével a törésmutatót folytonos függvényként állítja elő (ennek jelentősége főként a szenzorikai mérések során körvonalazódik, hiszen így válik lehetővé a törésmutató valós idejü követése minden időpillanatban). Az optikai paraméterek kiszámításához három egymásra épülő modellt alkalmaztam. A 1) szilárdest modellben három komponenst vettem figyelembe: egy hullámhossz-függő törésmutatóval rendelkező szilárd komponenst (részecskét), melynek refrakciós indexét szakirodalomban fellelhető információkból rekonstruáltam Cauchyegyütthatók segítségével; egy konstans törésmutatójú szilárd alkotót (a kötőanyag), ennek látható tartományban kismértékü - diszperzióját elhanyagoltam; konstans törésmutatóval 
rendelkező pórusokat, melyek értéke a levegő törésmutatója. Az 2) effektív közeg modellel homogenizáltam a vékonyréteget, mely a legegyszerübb esetben is két szilárd komponensből és pórusokból áll, valamint felületi érdességgel rendelkezik. Ennek eredményeképp kaptam egy állandó rétegvastagsággal és homogén törésmutatóval rendelkező rendszert. Az irodalomban számos fellelhető modell közül a 3 komponensre kiterjesztett Bruggeman-féle effektív közeg közelítést választottam. Ez az egyik legelterjedtebb modell, másfelől a számítógépes kiértékelö programba is könnyen beépíthetőnek bizonyult. A 3) hullámterjedési modell határozza meg, hogy levezetéseink során milyen, a hullámterjedésre, interferenciára vonatkozó egyenleteket, elméleteket használunk fel. Az immáron homogenizált rétegre vonatkozóan kétsugaras interferencia modellt alkalmaztam, azaz csak a réteg felületéről közvetlenül visszaverődő és a filmen keresztülhaladó, hordozó felületéről visszaverődő sugarakat összegeztem, komplex amplitúdók módszerével. A többi sugár elhanyagolása csak a reflektált fény intenzitásában okoz változást, a szélsőértékek helyében nem. A fenti három modell egyidejü, egymásra épülő alkalmazásával kaptam végeredményül egy összefüggést, amely a reflektált fényintenzitás és a hullámhossz közt teremt kapcsolatot. A kapott egyenlet alapján egy saját fejlesztésű szimulációs szoftverrel a legjobb illeszkedés alapján határoztam meg a vékonyrétegek rétegvastagságát és effektív törésmutatóját.

A hagyományos bemerítéses eljárás mellett fotopolimerizációval ötvözött technikával is állítottam elő cink-peroxid / polimer vékonyrétegeket, melynek eredményeképpen térhálós polimer tartalmú filmeket nyertem. Az eljárás során kombináltam az önrendeződéses filmépítés és fénysugárzás hatására történő polimerizáció elemeit. A poli(akrilamid) és a poli(N-izopropil-akrilamid), mint térhálós polimerek a tömbi fázisú kísérletek során (mint hidrogélek) eltérően viselkedtek: a poli(akrilamid) hidrofil, míg a poli(N-izoproplil-akrilamid) túlnyomórészt hidrofób tulajdonságokat hordoz. Fourier-transzformációs infravörös spektroszkópiával igazoltam, hogy a felépített $\mathrm{ZnO}_{2}$ /akrilamid és $\mathrm{ZnO}_{2} / \mathrm{N}$-izopropil-akrilamid hibrid vékonyrétegek térhálósító és fotoiniciátor oldatokba való merítés, és ultribolya fénnyel való besugárzás után $\mathrm{ZnO}_{2} /$ poli(AAm) és $\mathrm{ZnO}_{2} /$ poli(NIPAAm) filmekké alakultak. Víz- és etanolgőz adszorpciós kísérleteket végeztem abból a célból, hogy megvizsgáljam, a térhálós polimerek (PAAm, PNIPAAm) milyen hasonló illetve eltérő tulajdonságokkal bírnak vékonyrétegekben a tömbi fázishoz képest. $\mathrm{E}$ célból $\mathrm{ZnO}_{2}$ nanorészecskékből és akrilamidból ill. N-izopropil-akrilamidból vékonyrétegeket építettem (referencia), majd polimerizáltam (minta). Megállapítottam, hogy a polimerizáció következtében minden esetben csökkent az adszorbeált víz és etanol mennyisége. Ez azzal magyarázható, hogy míg monomer állapot 
esetén számos kötőhely áll rendelkezésre a víz- és etanol molekulák számára, addig a polimerek esetében a térháló kialakulásával sok kötőhely eltünik az adszorptívum elől. Csak a $\mathrm{ZnO}_{2} / \mathrm{AAm}$ és a $\mathrm{ZnO}_{2} /$ poli(AAm) hibridek etanol adszorpciójánál volt megfigyelhető a növekedés a polimerizált forma javára. A részlegesen hidrofil/hidrofób hibridek közel azonos mennyiségü vizet és etanolt kötöttek meg, valamivel több etanolt, míg jelentősen nagyobb mennyiségü vizet adszorbeáltak a dominánsan hidrofil vékonyrétegek. Az eredmények jó összhangban állnak a tömbi fázisban kapott adatokkal.

További célom volt a vékonyrétegek szenzorként való alkalmazhatóságát vizsgálni saját fejlesztésű áramlásos rendszerben, különböző polaritású gőzök jelenlétében. Megállapítottam, hogy az elkészített $\mathrm{ZnO}_{2} / \mathrm{PSS}$ hibrid vékonyrétegek reflexió spektruma a nagyobb hullámhosszak irányába tolódik, ha etilalkohol ill. víz gőzével telített atmoszférába helyezem. Az aktuális időpillanatban mért reflexió spektrumok és a $t=0$ spektrum - pontonkénti hányadosa (,relatív reflexió”) olyan görbék halmazát eredményezte, melyek szélsőértékeinek mind a helye, mind pedig az amplitúdója növekedett az idő múlásával. Ez utóbbi adja meg azt, hogy az adott hullámhosszon hányszorosára növekedik a visszavert fény intenzitása, azaz szenzor esetén mekkora jelnövekedés érhető el a kimutatandó anyag jelenlétében. Ezt a jelenséget kihasználva fejlesztettem gőzök adszorpciójának kimutatására és jellemzésére alkalmas, optikai elven müködő eszközt (szenzort). A négycsatornás áramló rendszerü gázszenzor része egy fényforrás, egy hőmérsékletméréssel ellátott mintaadagoló egység, egy gázkeverő rendszer (melyben a gőz(ök) és a nitrogén arányával változtatható a koncentráció), egy mintatartó- és mérőcella, valamint egy fotométer, mint detektor. A rendszer alkalmas reflexió spektrumok másodpercenkénti rögzítésére, melynek során a spektrum valamely szélsőértékének eltolódásából ( $\Delta \lambda$ ) törésmutató változást számít. A mérések sarkalatos pontja a szélsőérték keresése, mert a müszer zajszintje meghaladja azt az értéket, amennyi különbség lehet két szomszédos pixelen mért intenzitás érték között, ezért a szélsőérték keresés hamis eredményt adhat. A valódi szélsőérték megtalálásához kilencedfokú polinom illesztését végeztem el, ennek eredményeképpen kiváló hatásfokú simítást értem el, ezzel használható mérési adatokat nyertem. A törésmutató változásokból kvarckristály mérleggel történő kalibrációval következtettem az adszorpció mértékére. A $\mathrm{ZnO}_{2} / \mathrm{PSS}$ hibrid filmeket felületmódosítással szelektívvé tettem. Oktántiollal borított arany nanorészecskékkel és butiltriklórszilánnal módosítottam $\mathrm{ZnO}_{2} / \mathrm{PSS}$ vékonyrétegek felületét, ezzel szabályoztam a vékonyrétegek specifikus érzékenységét ill. hidrofobitását. A butil-triklórszilánnal való felületmódosítás során azt tapasztaltam, hogy a felület különösen szelektívvé vált etilalkohol 
gőzére, a fajlagos adszorbeált mennyiség a felületkezelés után közel kilencszerese volt az eredetinek. A vízgőz adszorpciója ezzel szemben alig háromszorosára nőtt, így ez a mennyiség negyed része az adszorbeált etanol mennyiségének a felületmódosított mintán. A hexán adszorpciója lényegesen nem változott a felületkezelés hatására. Az oktántiollal borított arany nanorészecskékkel történő (második) kezelés hatására a vékonyréteg teljesen hidrofóbbá vált, a vízgőz adszorpciója közel ötöd részére csökkent, míg a hexáné háromszorosára nőtt, így összességében kimagasló érzékenységet, 28-szor nagyobb törésmutató változást tapasztaltam hexán adszorpció esetében, mint a vízgőz esetén. 


\section{Függelék}

\section{1. számú függelék - Az áramlásos mérőrendszer müködésének bemutatása}

A 4.2 fejezetben bemutattam azokat az egyenleteket és az eljárást, amelyek felhasználásával számítható a vékonyrétegek rétegvastagsága és hullámhosszfüggő (diszperzív) törésmutatója. Ezek az értékek $\mathrm{N}_{2}$ atmoszférában vagy légszáraz körülmények között értendőek. Miután meghatároztuk ezeket az állandókat, a szenzorként funkcionáló filmeket adszorpciós kísérleteknek vethetjük alá. Az elméletben felhasználtuk azt a tényt, hogy a levegő, s ezáltal a pórusok törésmutatója $n_{0}=1$. Ha azonban a vékonyréteg olyan környezetbe kerül, mely tartalmazza szerves oldószerek (metanol, etanol, hexán, toluol stb.) gőzeit, akkor a felületen és a pórusokban megjelennek a gőz molekulái, a relatív gőznyomás értékétől függő mennyiségben. Ez mikroszkopikusan azt jelenti, hogy a pórusok törésmutatója $n_{0}>1$ lesz, makroszkopikusan pedig azt, hogy az effektív törésmutató megnövekedése miatt a reflexió spektrumok a nagyobb hullámhosszak irányába tolódnak el. Az eltolódás időbeni követése, azaz annak mértékéből a törésmutató folyamatos számítása egy adott hullámhosszon - kalibráció alapján - jelenti a szenzor müködési alapelvét. Ennek részletes menetét alább mutatom be, a 68. ábra segítségével:

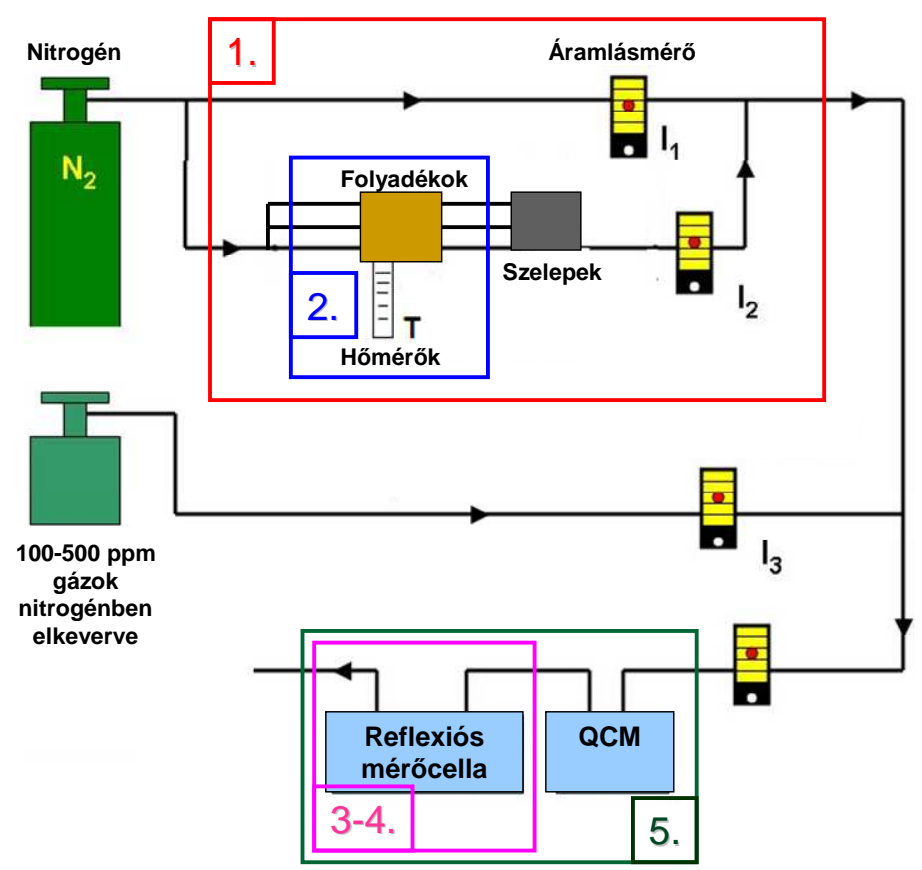

68. ábra A gözszenzor sematikus elrendezése, és logikai felosztása egységekre:

1: gázkeverö rendszer, 2: hömérséklet meghatározás,

3: minimum-keresés, 4: törésmutató számítás, 5: kalibráció kvarckristály mikromérleggel 
Gázkeverő rendszer: a mérendő gázokat/gőzöket áramlásos keverőrendszerrel juttattam a mérőcellá(k)ba. Ennek megfelelően a statikus rendszerben használt relatív gőznyomásról áttértem a gőzök parciális nyomását ill. koncentrációját jellemző torr ill. ppm mértékegységekre (megjegyzés: ismerve az adszorptívumok telítési koncentrációját, ez esetben is bevezethető természetesen a relatív gőznyomás fogalma). A 68. ábra jelöléseit használva: az 1. ágban haladó tiszta nitrogén áram áramlási sebessége $I_{1}[\mathrm{~mL} / \mathrm{s}]$, a 2 ágban pedig a folyadékok gőzeit tartalmazó nitrogén áram sebessége $I_{2}[\mathrm{~mL} / \mathrm{s}]$, a kettő összege $I_{0}$ [mL/s]. A gáztörvényekböl ismert

$$
p V_{m}=R T
$$

összefüggést felhasználva kapjuk, hogy

$$
c=p / R T
$$

ahol $p$ a gőz parciális nyomása*, $V_{m}$ a moláris térfogata, $R$ a gázállandó, $T$ a folyadék pillanatnyi hőmérséklete (lsd. 2. pont), $c$ pedig a $[\mu \mathrm{g} / \mathrm{mL}]$ mértékegységben kifejezett gőzkoncentráció a folyadék felett (*: a gőzök parciális nyomását Antoine-koefficiensek felhasználásával számítottam). Az edényen áthaladó $I_{2}$ áram másodpercenként

$$
[\mathrm{mg} / \mathrm{mL} \cdot \mathrm{mL} / \mathrm{s}] c \cdot I_{l}=m_{1}[\mathrm{mg} / \mathrm{s}]
$$

tömegü gőzt visz magával. Ennek térfogata másodpercenként $V[\mu \mathrm{L} / \mathrm{s}]$, a két ágban összesen pedig $I_{0}{ }^{\prime}[\mathrm{L} / \mathrm{s}]$ nitrogén áram halad, így a kettő aránya ( $\left.V / I_{0}{ }^{\prime}\right)$ adja a gőzkoncentrációját a mérőcellában $[p p m=\mu L / L]$. A tiszta és gőztartalmú nitrogén áramok arányának fokozatos változtatásával pedig folyamatosan növelhető a gőzkoncentrációja - nulla és telítés közt - a mérés során.

Ha a 2. ágba $n$ darab különböző folyadékot tartalmazó edényt csatolunk be, akkor ennek megfelelően az egyes komponensek koncentrációja is $n$-ed részére esik (feltételeztem, hogy az $\mathrm{I}_{2}$ ágban haladó nitrogén áram egyenlő térfogatáramú részekre oszlik el az elágazásnál). Ugyanígy ha a 3. ág (amelybe az előre bekevert gázokat kapcsolhatjuk) is az áramba van csatolva, akkor az $I_{3}$-nak megfelelő mennyiségü nitrogén hígítja az $I_{0}$ áramban lévő koncentrációt. Tekintettel arra, hogy a bemutatott méréseim során ez utóbbira nem került sor, ennek részletes tárgyalásától eltekintek, de megfelelő egyenletekkel természetesen számítható. 
Hőmérséklet meghatározás: a mérések egyik kritikus pontja a hőmérséklet ismerete, mert a folyadék feletti parciális gőznyomás ennek (közel) exponenciális függvénye. Tapasztalataim azt mutatták, hogy az illékony szerves folyadékok (pl. etanol, hexán) olyan mértékben hülnek a kísérletek során - közel fél óra alatt akár $8-10{ }^{\circ} \mathrm{C}$ fokot is -, hogy a termosztáló egység képtelen konstans hőmérsékleten tartani azokat. Ezért a folyadékok hőmérsékletét minden mérési (helyesebben adatrögzítési) időpontban rögzítettem, ezzel párhuzamosan számítottam is azt. A két adat - a környezettel való hőcserét figyelembe véve kiváló egyezést mutatott a mérések során (1sd. 69. ábra).

Az i-edik adatrögzítési pontban $T_{i}$ a folyadék hőmérséklete és $\mathrm{n}_{\mathrm{i}}$ a göztérben lévő anyag mennyisége. Ennek elpárolgásához

$$
Q_{i}=L_{p} \cdot n_{i}
$$

energiára van szükség, ahol $L_{p}$ a párolgáshő. A folyadék kiindulási $m_{i}$ tömegét és $c$ fajhőjét ismerve kapjuk, hogy a folyadék hülése:

$$
\Delta T=Q_{i} / c \cdot m_{i}
$$

Az így kapott $T_{i+1}=\left(T_{i}-\Delta T\right) \cdot\left(1+\left(T_{\text {külso }} T_{i}\right) W^{*}\right.$ hőmérsékletet használjuk fel a következö ciklusban, a folyadék új tömegét $m_{i+1}=m_{i}-M \cdot n_{i}$ összefüggésböl nyerjük. Ennek megfelelően pedig minden egyes $i$. idöpillanatban a korábban bemutatott összefüggésekkel számíthatjuk az aktuális parciális nyomást, tömegáramot és gőzkoncentrációt.

*: a folyadékot tartalmazó edény és a környezet között természetesen van hőcsere, ezt vettem figyelembe egy $1+\left(T_{k u ̈ l s o ́}-T_{i}\right) W$ szorzófaktorral. W értékét az egyes adszorptívumok (víz, etanol, hexán) esetén tapasztalati úton határoztam meg az első mérések alkalmával, majd a további kísérletek során mindig ugyanezt az értéket használtam fel. $W_{v i z}=0.0000019$, $W_{\text {etanol }}=0.0000151, W_{\text {hexán }}=0.0000104$. 


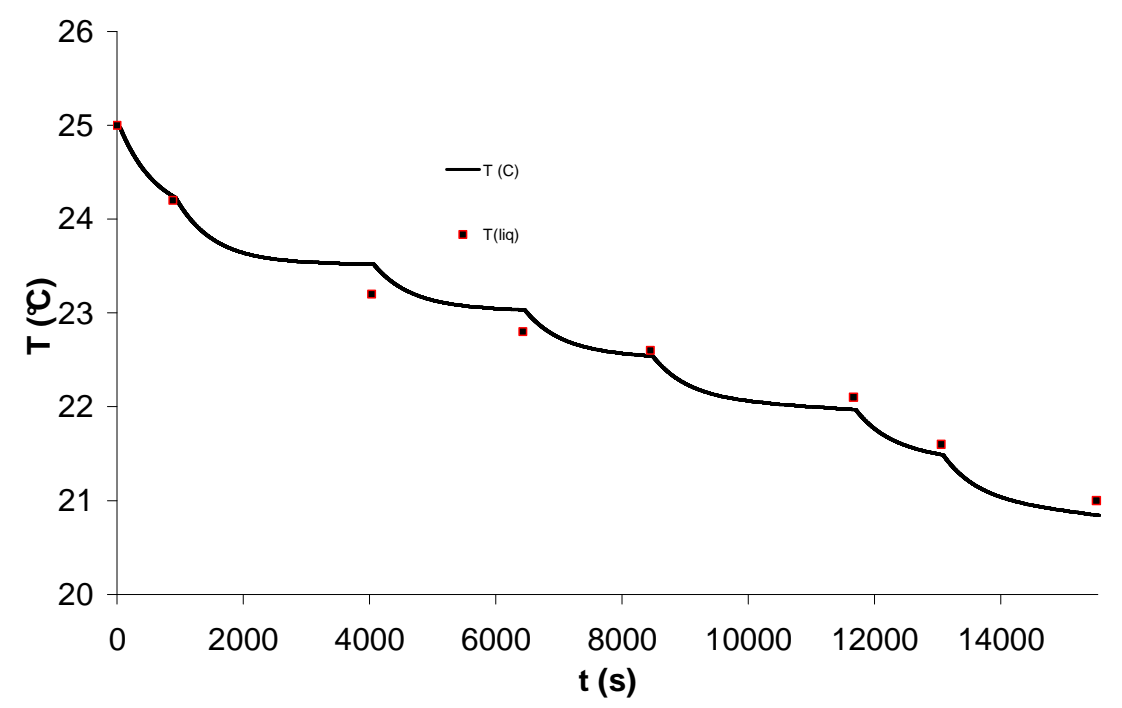

69. ábra A számított (folytonos vonal) és az adatrögzítési idöpillanatban leolvasott (piros pontok) hömérsékletek összehasonlítása

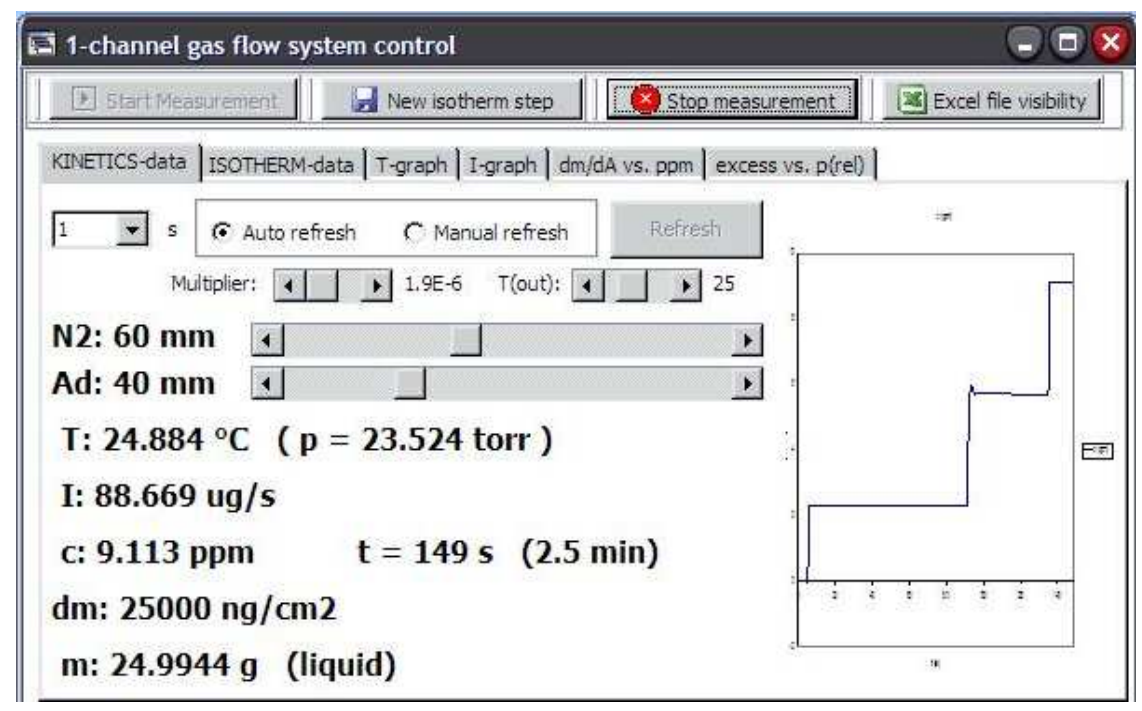

70. ábra A folyadékra és gözre jellemzö mennyiségek pillanatnyi értéke (bal oldalon), valamint a gözkoncentráció monitorozása az idö függvényében (jobb oldalon)

Párolgási sebesség meghatározása: Jogosan merülhet fel a kérdés azzal kapcsolatban, hogy az áramló rendszer folyadéktartó edényében, a folyadék felszíne felett vajon mindig rendelkezésre áll-e olyan mennyiségü gőz, aminek az eltávozásával számolunk, azaz a párolgás van-e olyan gyors folyamat, mint feltételezzük róla. Erre nézve a következő számítást végezhetjük el [116]: 


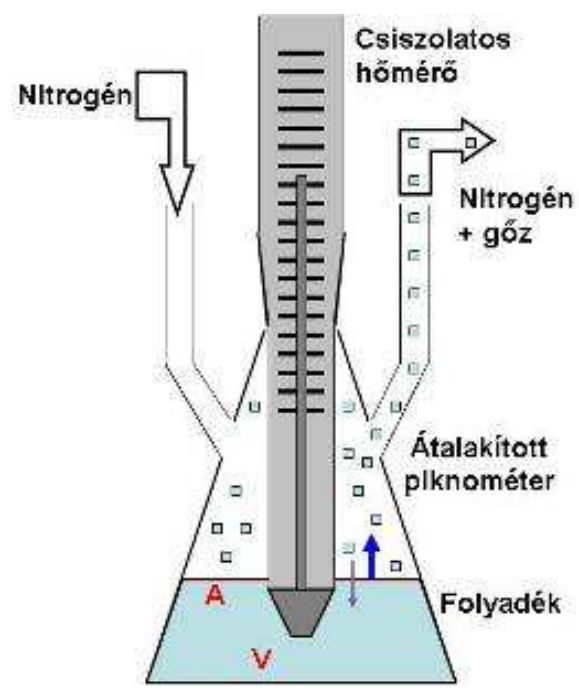

71. ábra A kísérletekhez használt folyadéktartó edény (átalakított piknométer)

Tételezzük fel, hogy, a folyadékban lévő molekulák sebességeloszlása Boltzmann-eloszlás, ahogyan az ideális gázban is [117]. A molekulák egy része rendelkezik akkora energiával és sebességgel (ez alatt természetesen a felületre merőleges komponenst értem), amely elegendő nagyságú ahhoz, hogy a molekulák közti vonzó erőt $(L)$ legyőzve kiszakadjon a folyadékfelszínből, s a gőztérbe jusson (a folyadék belsejében ez nyilván nem lehetséges, hiszen ott a molekulákra ható erők kiegyenlítik egymást).

Annak a feltétele, hogy egy $m$ tömegü, $v$ sebességü molekula elhagyja a vízfelszínt:

$$
\frac{1}{2} m v^{2} \geq L
$$

Így elpárologni csak azok a molekulák fognak, amelyek felületre merőleges komponensére igaz, hogy

$$
v \geq \sqrt{\frac{2 L}{m}}
$$

Vezessük be a

$$
\alpha=\frac{m}{2 k T}
$$

jelölést, mellyel a $v$ és $v+d v$ közé eső - felületre merőleges - sebességkomponenssel rendelkező molekulák koncentrációja

$$
\mathrm{dn}_{\mathrm{f}}=n_{f}\left(\frac{\alpha}{\pi}\right)^{1 / 2} e^{-\alpha v^{2}} d v
$$

ahol $n_{f}$ a molekulakoncentráció a folyadékban. 
Az egységnyi felületen végtelen kicsi $d t$ idő alatt a gőztérbe lépő, $v$ és $v+d v$ közötti sebességgel rendelkező molekulák azok lesznek, amelyek a $v d t$ mélységü térfogatban tartózkodnak. Egységnyi idő alatt egységnyi felületen így

$$
d N_{f}=v d n_{f}
$$

darab molekula lép ki. (29) és (30) -ból:

$$
\mathrm{dN}_{\mathrm{f}}=n_{f}\left(\frac{\alpha}{\pi}\right)^{1 / 2} e^{-\alpha v^{2}} v d v
$$

Kilépni csak azok képesek, amelyek sebessége nagyobb, mint a minimális $v_{0}$ sebesség:

$$
\mathrm{N}_{\mathrm{f}}=n_{f}\left(\frac{\alpha}{\pi}\right)^{1 / 2} \int_{v_{0}}^{\infty} e^{-\alpha v^{2}} v d v
$$

Az integrálást elvégezve a kilépő molekulák száma:

$$
\mathrm{N}_{\mathrm{f}}=\frac{n_{f}}{2}\left(\frac{1}{\alpha \pi}\right)^{1 / 2} e^{-\alpha v_{0}^{2}}
$$

Természetesen a kilépett molekulák egy része vissza is kondenzálódhat a folyadékba, hiszen a gőztér és a folyadék között dinamikus egyensúly igyekszik kialakulni. Kondenzációra minden molekula képes:

$$
\mathrm{N}_{\mathrm{k}}=n_{k}\left(\frac{\alpha}{\pi}\right)^{1 / 2} \int_{0}^{\infty} e^{-\alpha v^{2}} v d v=\frac{n_{k}}{2}\left(\frac{1}{\alpha \pi}\right)^{1 / 2}
$$

ahol $n_{k}$ a gőztérben lévő gáz halmazállapotú molekulák száma.

Zárt térben dinamikus egyensúly alakul ki, azaz az elpárolgó molekulák száma egyenlő a kondenzálódó molekulák számával:

$$
n_{c}=n_{f} e^{-\alpha v_{0}^{2}}
$$

Amennyiben a hőmérséklet is állandó, akkor a gőzök nyomása is állandó lesz, ezt nevezzük telítési gőznyomásnak. Esetünkben azt kell megállapítanunk, hogy egységnyi idő alatt egységnyi felületen mennyi molekula párolog el a folyadékból, hiszen tudnunk kell, hogy az áramló rendszerünkben viszonylag magas sebességek esetén is rendelkezésre áll-e kellő anyagmennyiség. Számításaim szerint a $10-500 \mathrm{~m} / \mathrm{s}$ tartományba eső sebességgel rendelkező folyadékmolekulák esetén az időegység alatt, felületegységenként a gőztérbe lépő molekulák száma 14.618 - $5.876 \mathrm{mgs}^{-1} \mathrm{~cm}^{-2}$ tartományba esik. Ez (a minimum) önmagában is nagyságrendekkel meghaladja azt a pufferigényt, amelyre szükség van ahhoz, hogy a $\mathrm{N}_{2}$ áram minden időpillanatban annyi gőzt szállítson magával, amennyit számítottam, ám rendelkezésünkre sokszor nagyobb felület áll, mint egységnyi $\left(1 \mathrm{~cm}^{2}\right)$, valamint a „szélsebességgel” növekszik a párolgás sebessége is. 
12. táblázat Elpárolgott anyagmennyiség a molekulák sebességének függvényében

\begin{tabular}{cccc}
\hline $\mathbf{v}_{\mathbf{0}}(\mathbf{m} / \mathbf{s})$ & $\mathbf{N}_{\mathbf{f}}\left(\mathbf{m g} / \mathbf{s} / \mathbf{c m}^{\mathbf{2}}\right)$ & $\mathbf{N}_{\mathbf{k}}\left(\mathbf{m g} / \mathbf{s} / \mathbf{c m}^{\mathbf{2}}\right)$ & $\Delta\left(\mathbf{m g} / \mathbf{s} / \mathbf{c m}^{\mathbf{2}}\right)$ \\
\hline $\mathbf{1 0}$ & $\mathbf{1 4 . 6 1 8 7 5 5 3 5}$ & $\mathbf{0 . 0 0 0 3 3 9 8 1 1}$ & $\mathbf{1 4 . 6 1 8}$ \\
200 & 12.63903594 & 0.000339811 & 12.639 \\
300 & 10.53223167 & 0.000339811 & 10.532 \\
400 & 8.15923496 & 0.000339811 & 8.159 \\
$\mathbf{5 0 0}$ & $\mathbf{5 . 8 7 6 2 6 0 7 3 7}$ & $\mathbf{0 . 0 0 0 3 3 9 8 1 1}$ & $\mathbf{5 . 8 7 6}$ \\
600 & 3.934370523 & 0.000339811 & 3.934 \\
700 & 2.448905572 & 0.000339811 & 2.449 \\
800 & 1.417070323 & 0.000339811 & 1.417 \\
\hline
\end{tabular}

Belső kalibráció: a szoftver mérés közbeni kiértékelésre alkalmas, a kísérlet minden másodpercében meghatároz termodinamikai és optikai paramétereket, ám szükséges a mért hullámhossz eltolódást törésmutató változássá konvertálni. Ennek oka, hogy a későbbiekben ez teszi lehetővé a fajlagos adszorbeált mennyiség meghatározását. Az átalakítás alapja, hogy a nagyobb hullámhosszak irányába történő eltolódást szimulálunk a törésmutató értékének kis léptékben való növelésével, majd az így kapott $\Delta \lambda-\Delta \mathrm{n}$ egyenesre történő illesztéssel meghatározzuk az egyenes meredekségét (72. ábra). A mérés során pedig ezen együttható felhasználásával számítjuk minden időpillanatban a hullámhossz eltolódásából a törésmutató változását, majd ezt ábrázoljuk az idő függvényében.

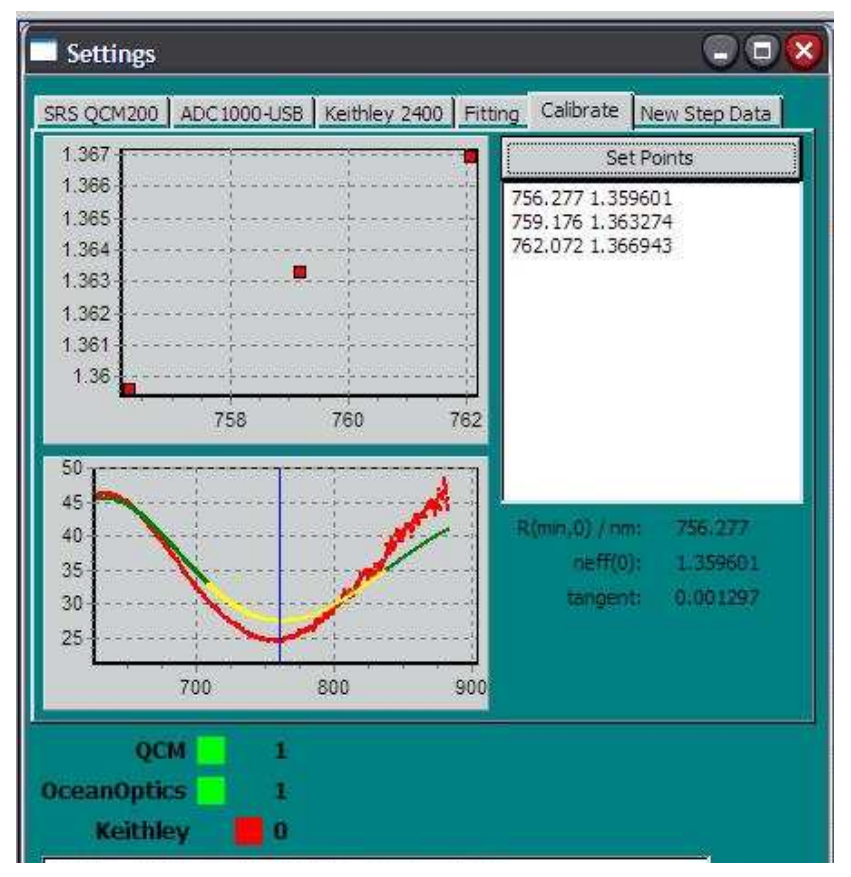

72. ábra A kalibráció menete (képernyö-fénykép) 


\section{2. számú függelék - A butiltriklórszilánnal módosított $\mathrm{ZnO}_{2} / P S S$ hibrid vékonyrétegen végzett mérési eredmények részletezése}

1. Kezeletlen minta, első minimum hely, vízgőz adszorpció:

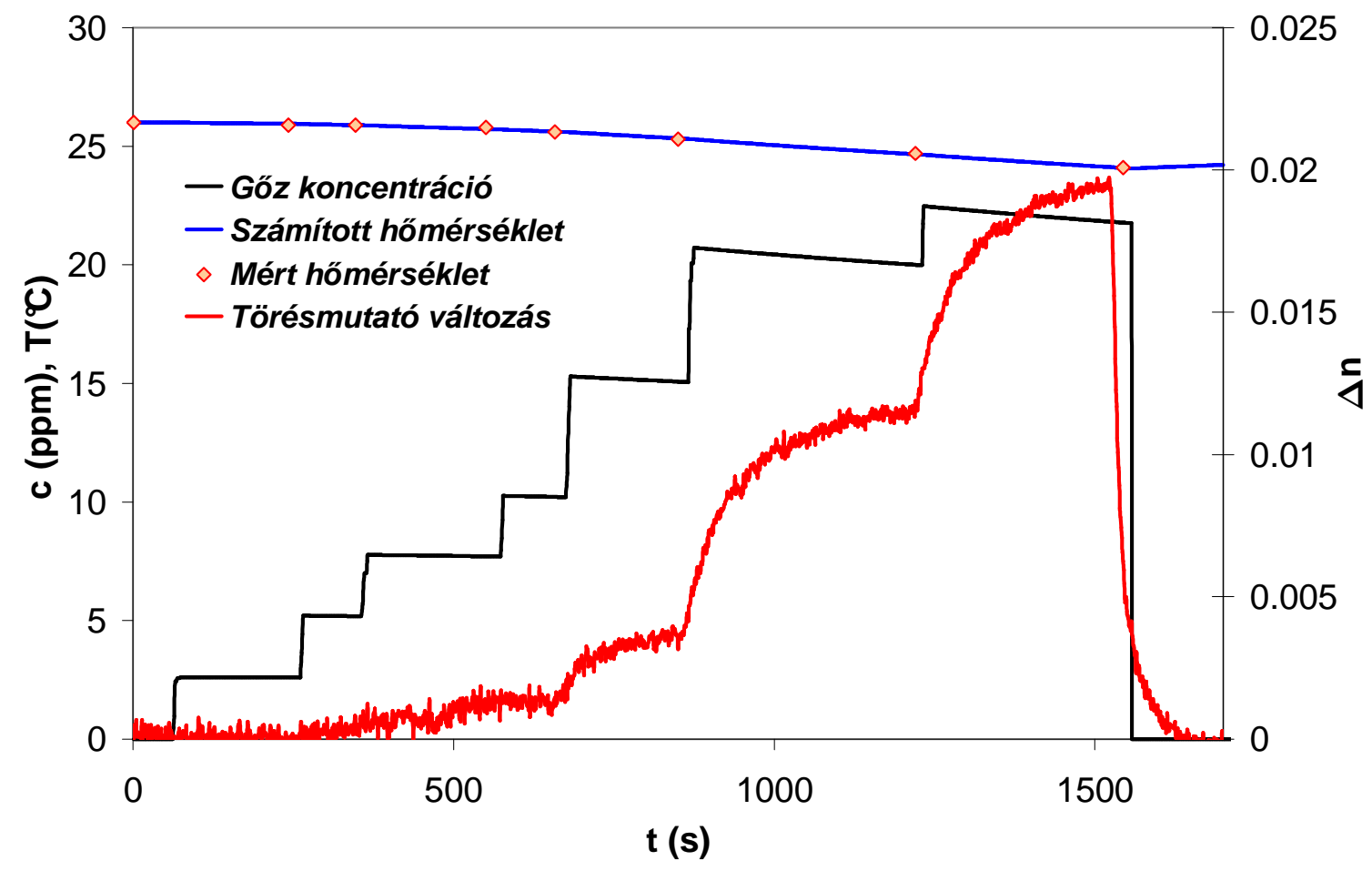

73. ábra Vizgőz hatására bekövetkezö törésmutató változás 20 kettösrétegü, kezeletlen $\mathrm{ZnO}_{2} / P S S$ mintán, az elsö minimum helyen ( $\lambda=424 \mathrm{~nm}$ ), valamint a gözkoncentráció és hömérséklet értéke a kísérlet időtartama alatt
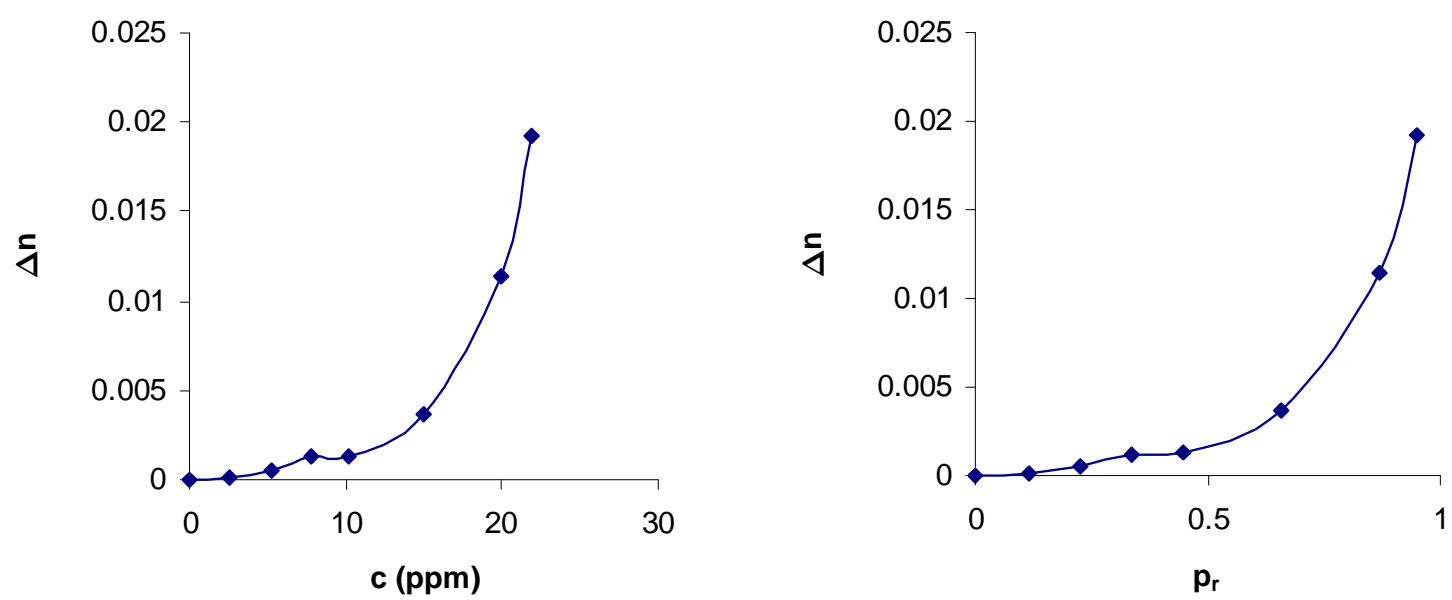

74. ábra Törésmutató változás a koncentráció ill. a relatív göznyomás függvényében, az elsö minimum helyen ( $\lambda=424 \mathrm{~nm}$ ), 20 kettösrétegü, kezeletlen $\mathrm{ZnO}_{2} / \mathrm{PSS}$ mintán, vízgöz jelenlétében 


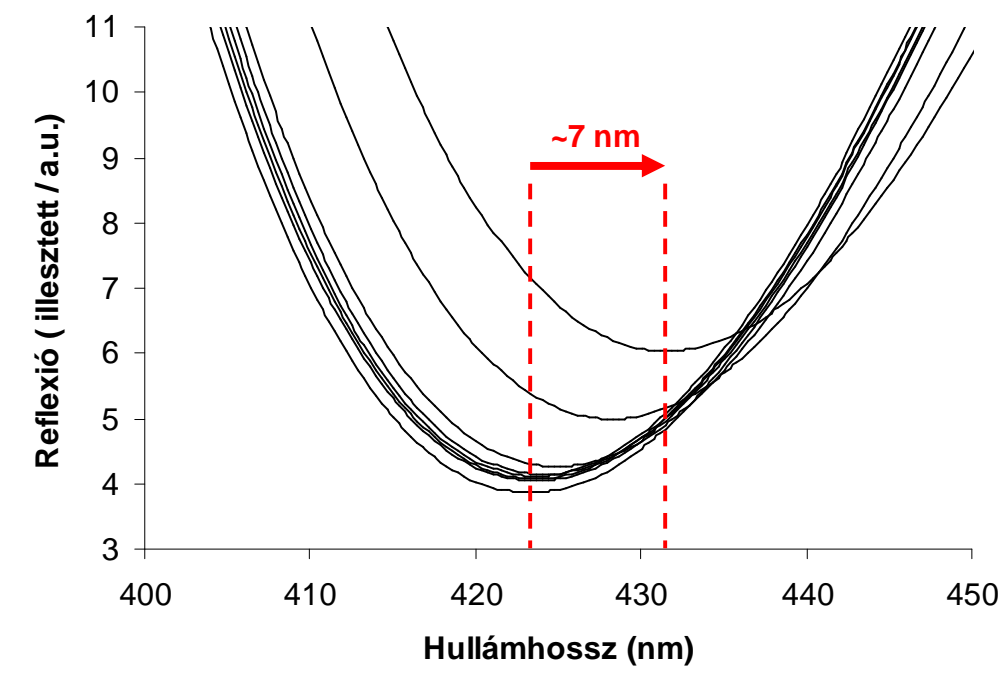

75. ábra Vízgöz hatására bekövetkezö reflexió spektrum eltolódás az elsö minimum helyen $(\lambda=424 \mathrm{~nm}), 20$ kettösrétegü, kezeletlen $\mathrm{ZnO}_{2} / \mathrm{PSS}$ mintán, vízgöz jelenlétében

\section{Kezeletlen minta, második minimum helyen, vízgőz adszorpció:}

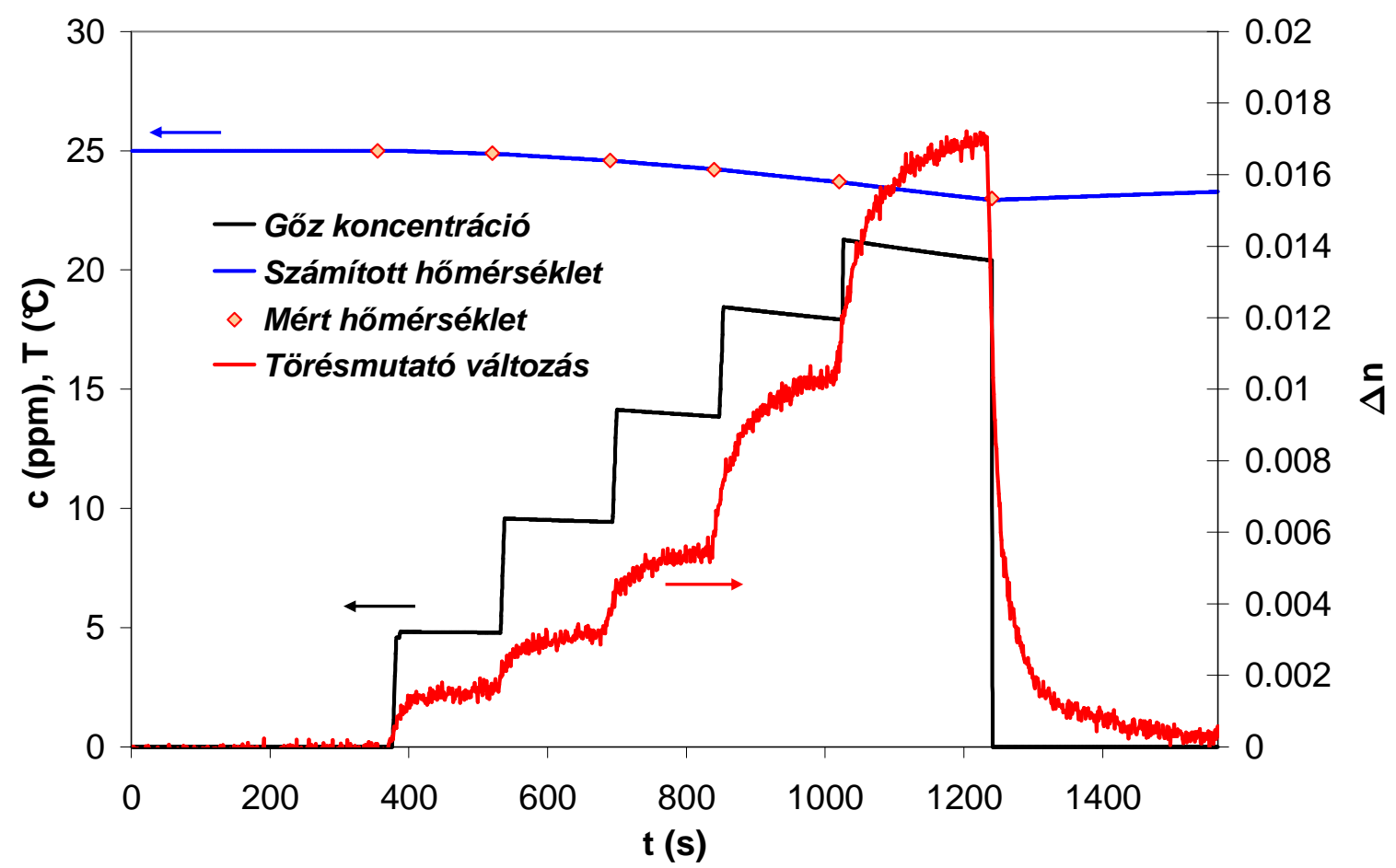

76. ábra Vizgöz hatására bekövetkezö törésmutató változás 20 kettösrétegü, kezeletlen $\mathrm{ZnO}_{2} / \mathrm{PSS}$ mintán, a második minimum helyen ( $\lambda=689 \mathrm{~nm}$ ), valamint a gözkoncentráció és hömérséklet értéke a kísérlet időtartama alatt 

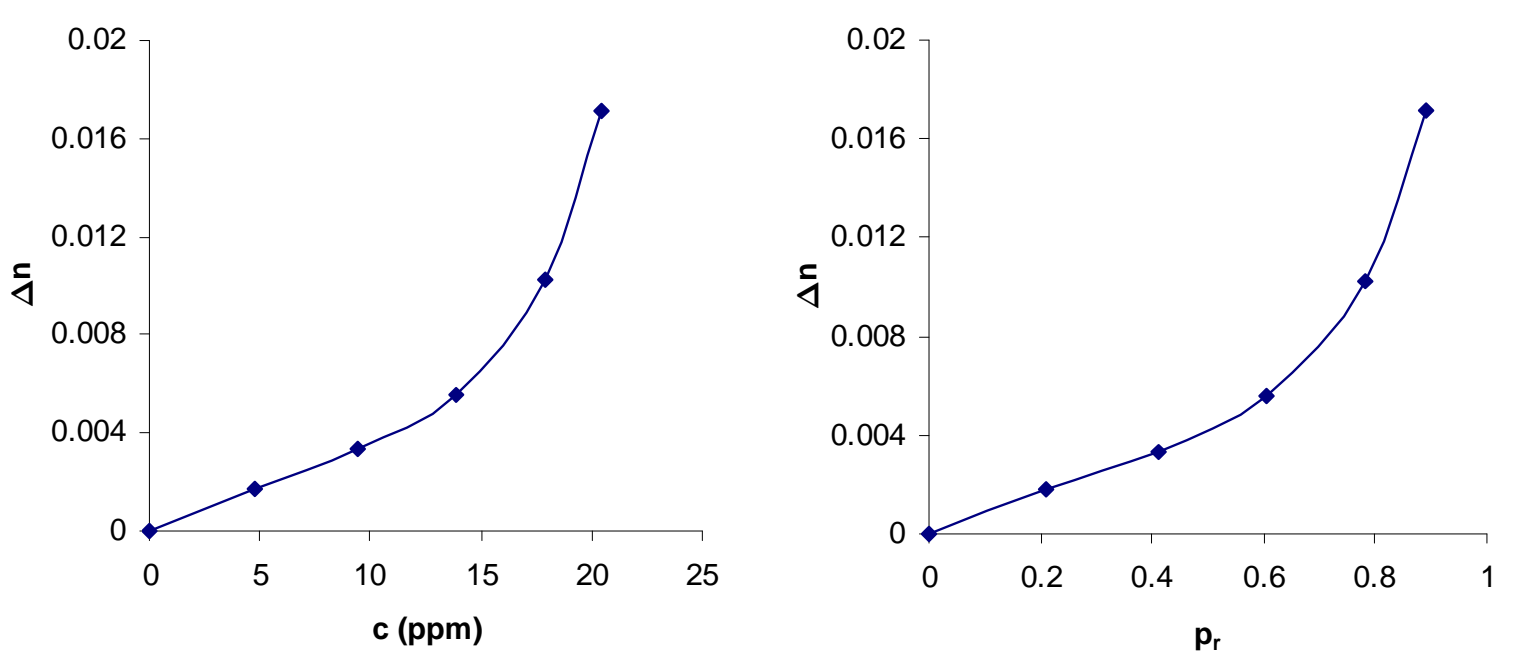

77. ábra Törésmutató változás a koncentráció ill. a relatív gőznyomás függvényében, a második minimum helyen ( $\lambda=689 \mathrm{~nm}$ ), 20 kettösrétegü, kezeletlen $\mathrm{ZnO}_{2} / \mathrm{PSS}$ mintán, vízgöz jelenlétében

\section{Kezeletlen minta, első minimum helyen, etanol adszorpció:}

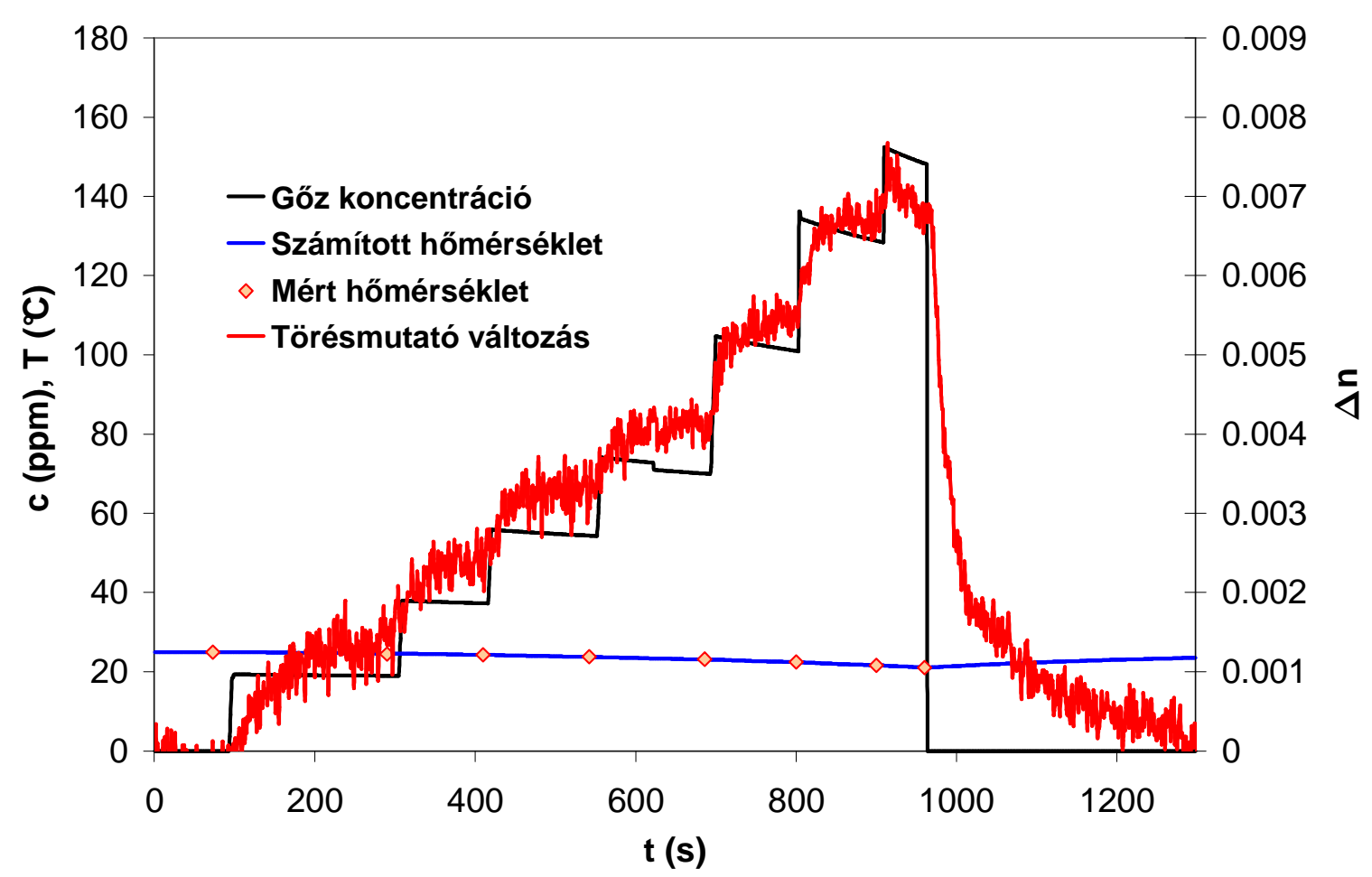

78. ábra Etilalkohol göz hatására bekövetkezö törésmutató változás 20 kettösrétegü, kezeletlen $\mathrm{ZnO}_{2} / P S S$ mintán, az elsö minimum helyen ( $\lambda=424 \mathrm{~nm}$ ), valamint a gőzkoncentráció és hömérséklet értéke a kísérlet időtartama alatt 

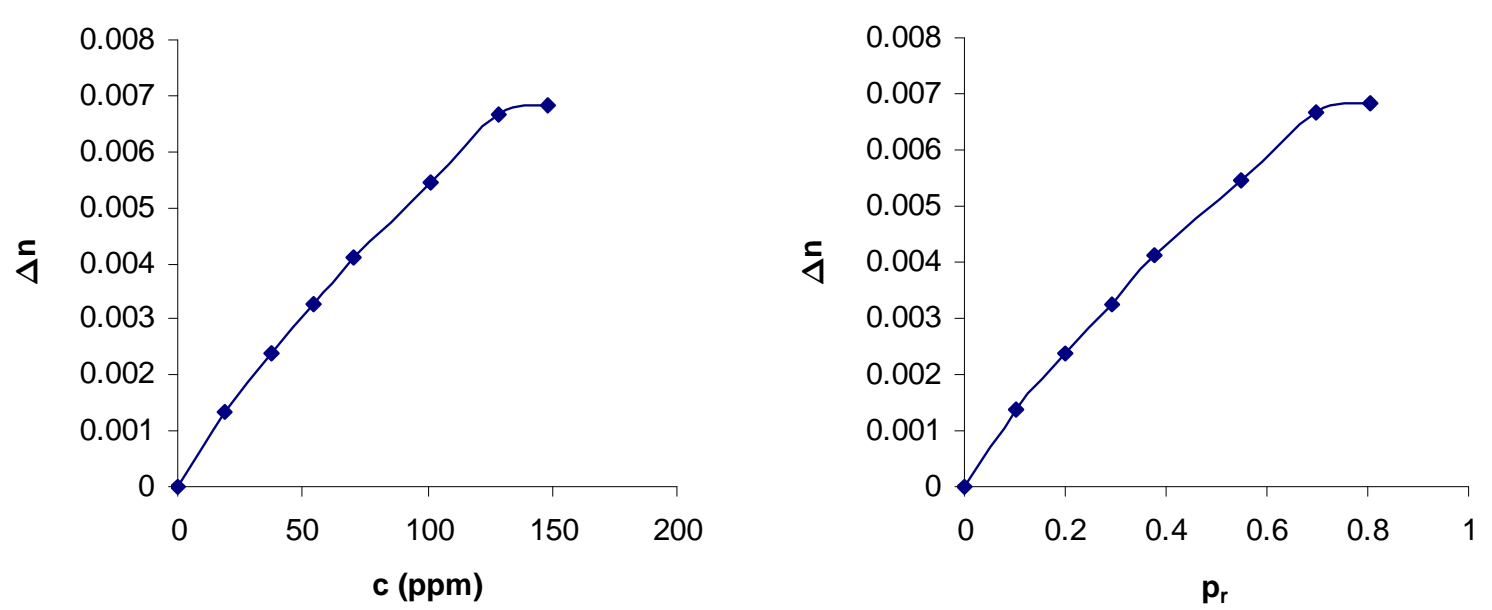

79. ábra Törésmutató változás a koncentráció ill. a relatív göznyomás függvényében, az elsö minimum helyen ( $\lambda=424 \mathrm{~nm}), 20$ kettösrétegü, kezeletlen $\mathrm{ZnO}_{2} / \mathrm{PSS}$ mintán, etanol göz jelenlétében

\section{Kezeletlen minta, második minimum helyen, etanol adszorpció:}

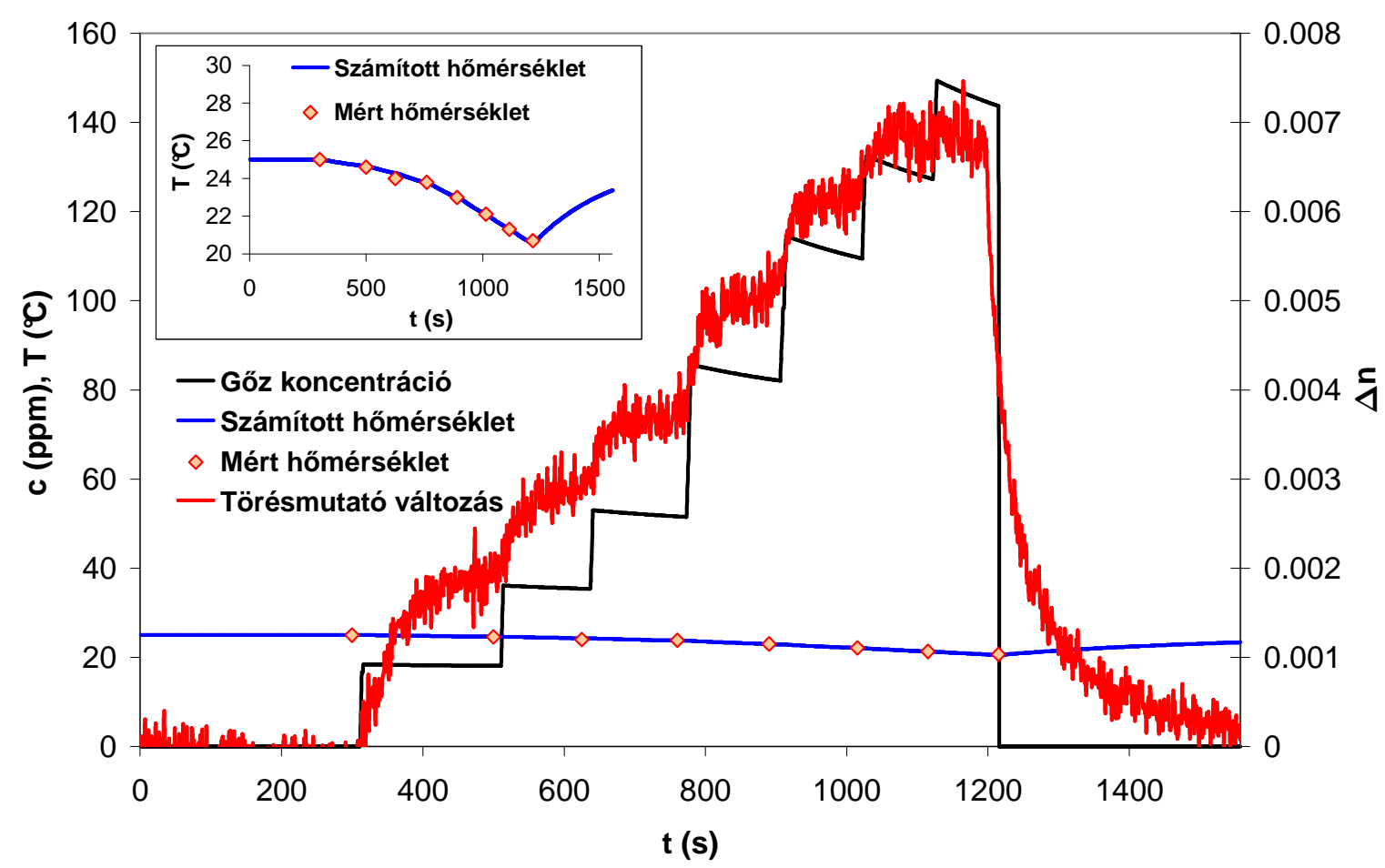

80. ábra Etilalkohol göz hatására bekövetkezö törésmutató változás 20 kettösrétegü,

kezeletlen $\mathrm{ZnO}_{2} / P S S$ mintán, a második minimum helyen ( $\lambda=690 \mathrm{~nm}$ ), valamint a gözkoncentráció és hömérséklet értéke a kísérlet időtartama alatt (Belsö ábra: a mért és számított hömérséklet) 

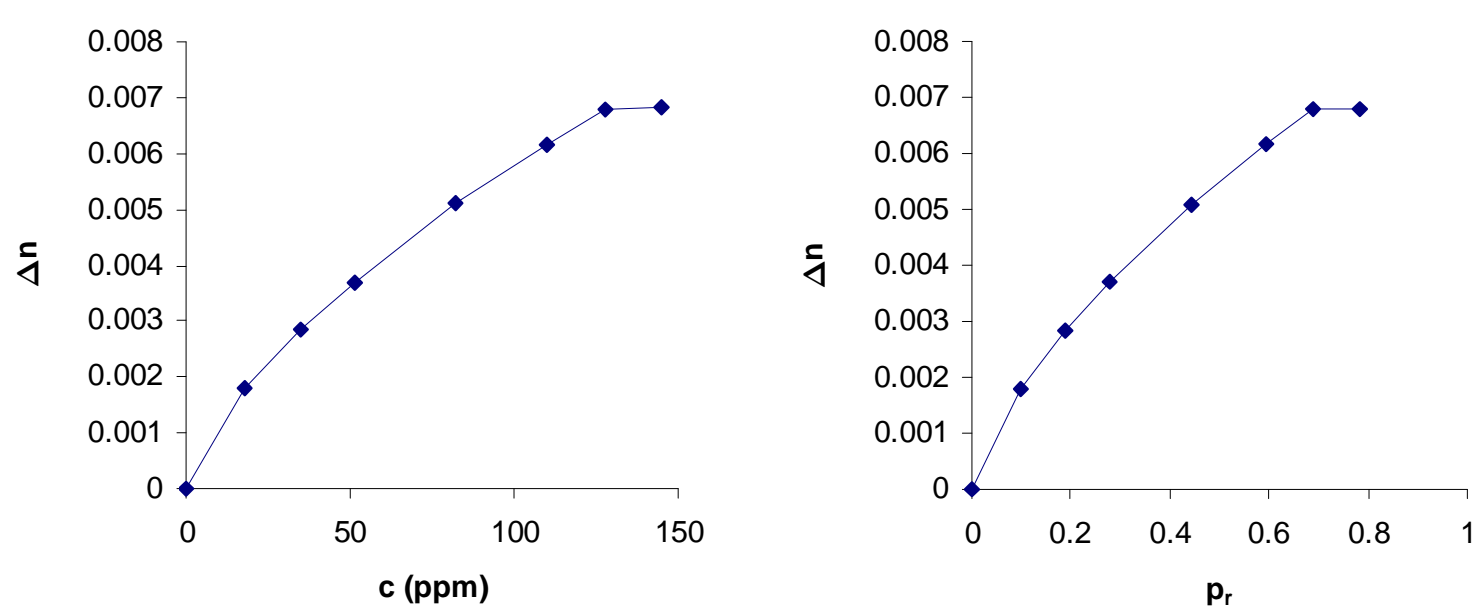

81. ábra Törésmutató változás a koncentráció ill. a relatív göznyomás függvényében, a második minimum helyen ( $\lambda=690 \mathrm{~nm}$ ), 20 kettösrétegü, kezeletlen $\mathrm{ZnO}_{2} / P S S$ mintán, etanol gőz jelenlétében

\section{$\underline{\text { 5. Kezeletlen minta, első minimum helyen, hexán adszorpció: }}$}

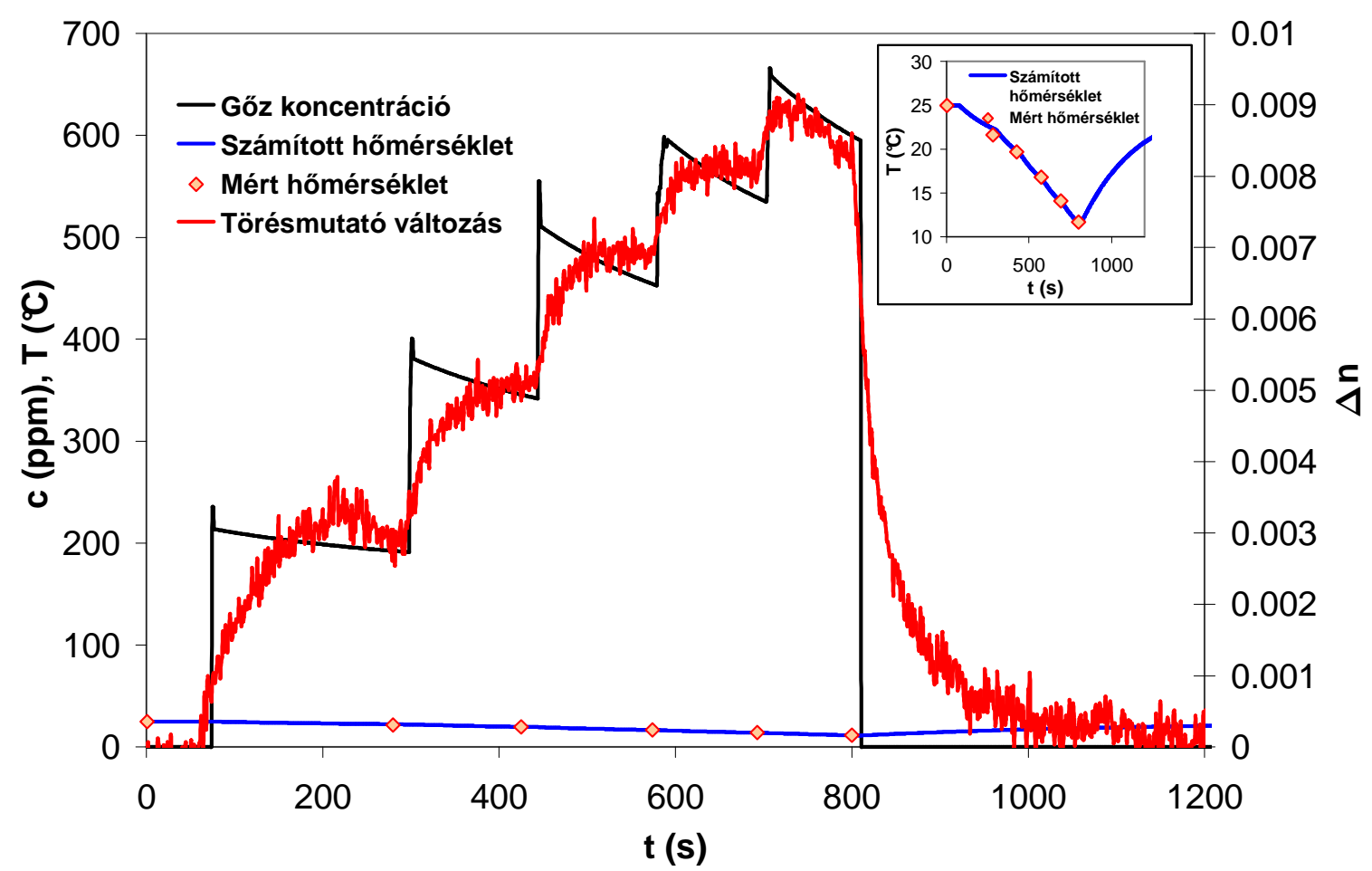

82. ábra Hexán göz hatására bekövetkezö törésmutató változás 20 kettősrétegü, kezeletlen $\mathrm{ZnO}_{2} / P S S$ mintán, az elsö minimum helyen ( $\lambda=424 \mathrm{~nm}$ ), valamint a gözkoncentráció és hömérséklet értéke a kísérlet időtartama alatt (Belsö ábra: a mért és számított hömérséklet) 

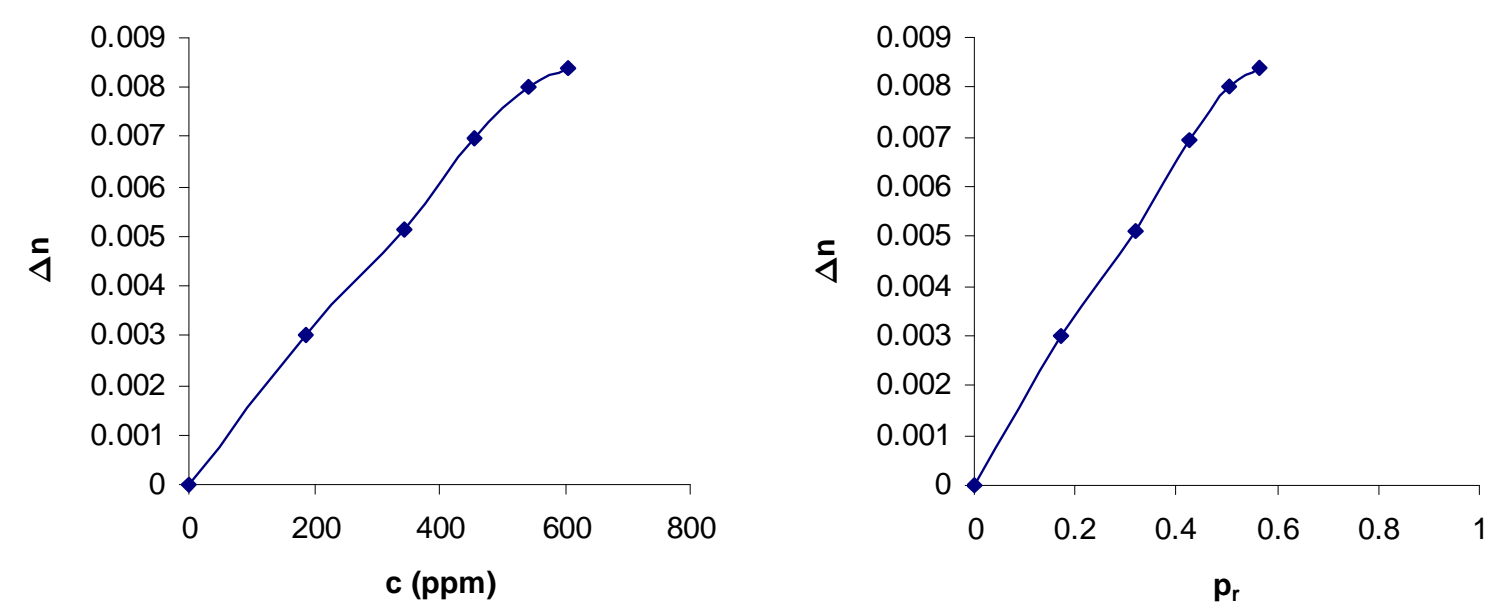

83. ábra Törésmutató változás a koncentráció ill. a relatív göznyomás függvényében, az elsö minimum helyen ( $\lambda=424 \mathrm{~nm}$ ), 20 kettösrétegü, kezeletlen $\mathrm{ZnO}_{2} / \mathrm{PSS}$ mintán, hexán göz jelenlétében

\section{Kezeletlen minta, második minimum helyen, hexán adszorpció:}

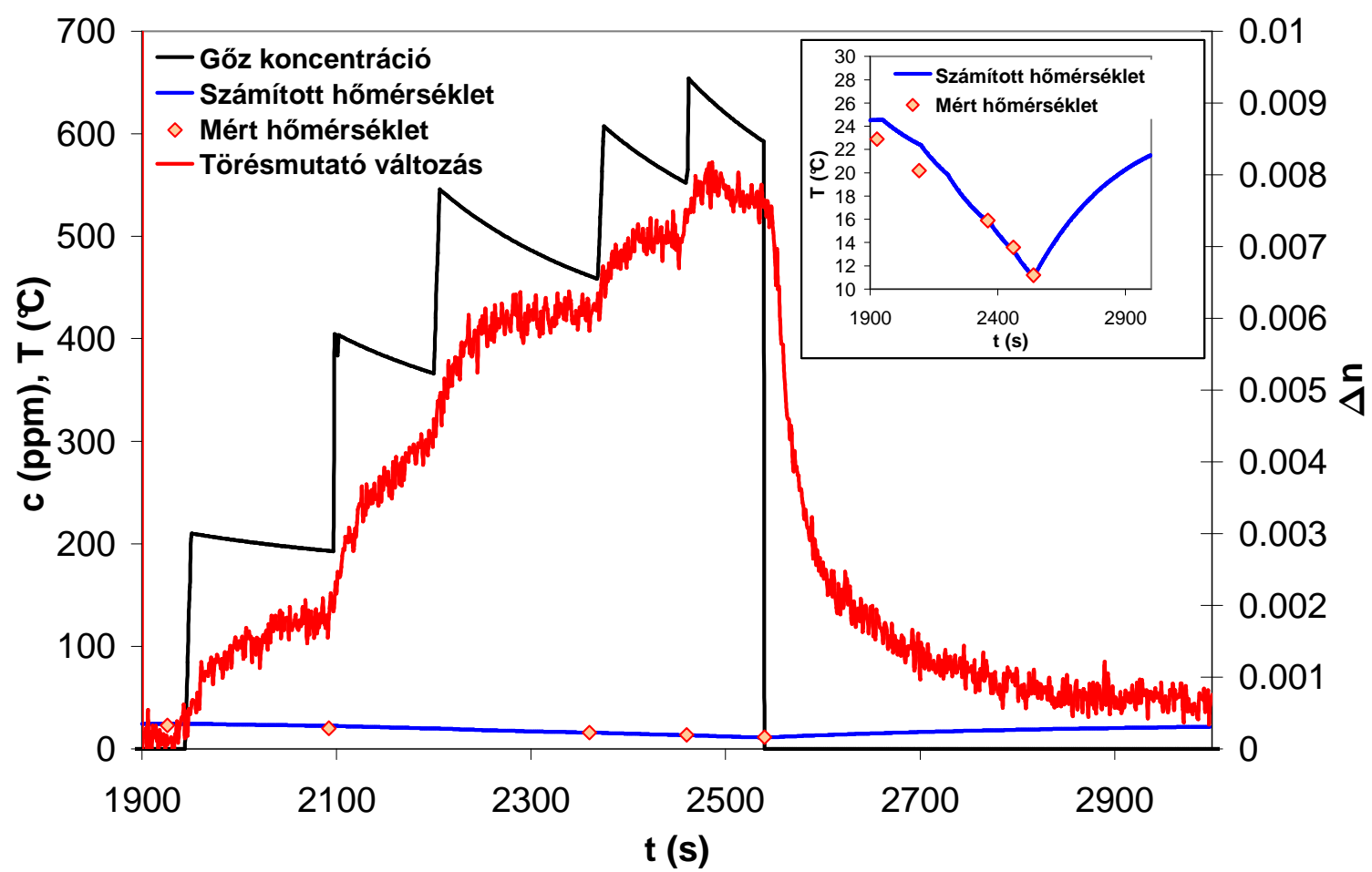

84. ábra Hexán göz hatására bekövetkezö törésmutató változás 20 kettősrétegü, kezeletlen $\mathrm{ZnO}_{2} / \mathrm{PSS}$ mintán, a második minimum helyen ( $\lambda=690 \mathrm{~nm}$ ), valamint a gözkoncentráció és hömérséklet értéke a kísérlet időtartama alatt (Belsö ábra: a mért és számított hömérséklet) 

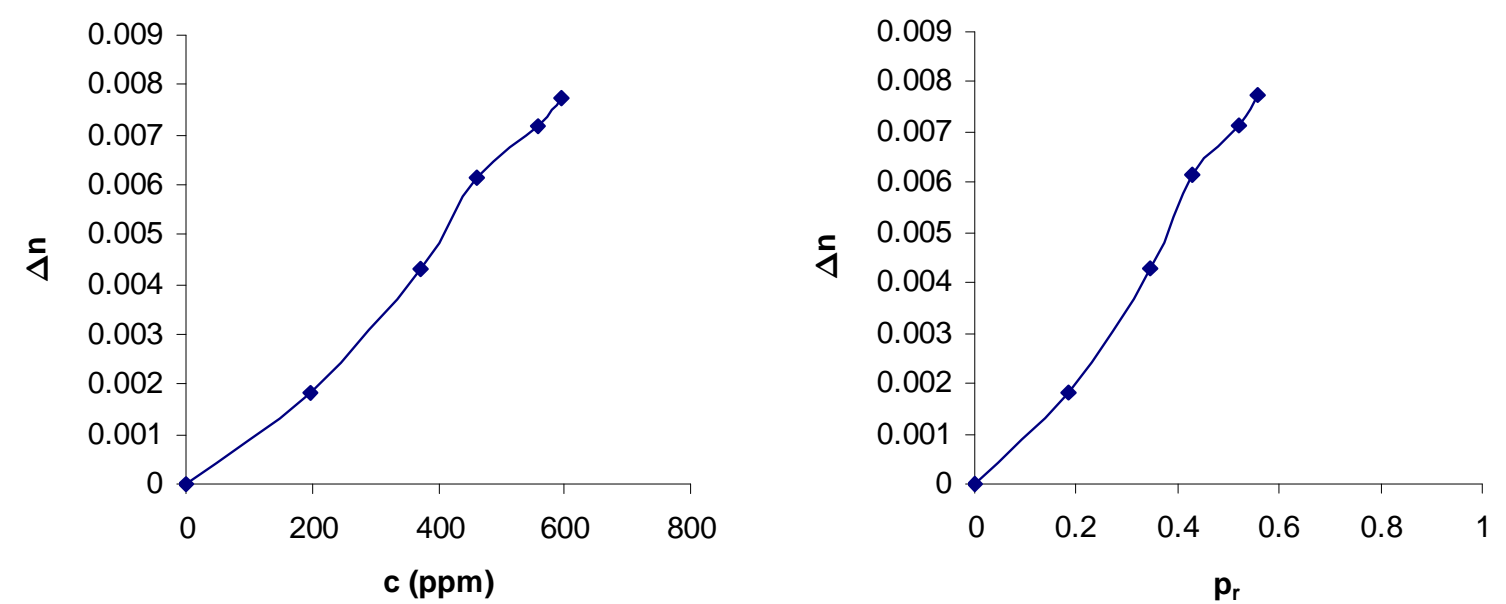

85. ábra Törésmutató változás a koncentráció ill. a relatív gőznyomás függvényében, a második minimum helyen $(\lambda=690 \mathrm{~nm}), 20$ kettösrétegü, kezeletlen [ $\mathrm{ZnO}_{2} / \mathrm{PSS}$ ] mintán], hexán göz jelenlétében

\section{BTS -nal egyszer kezelt minta, első minimum helyen, vízgőz adszorpció:}

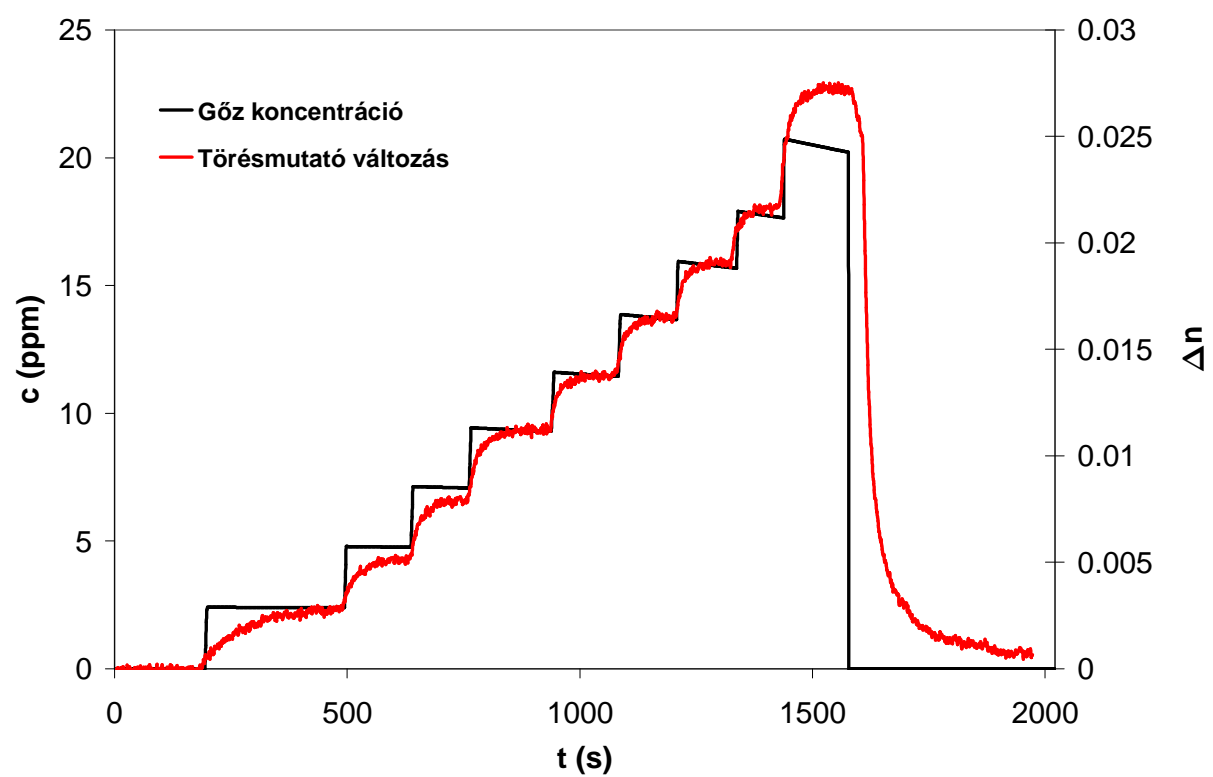

86. ábra Vizgőz hatására bekövetkezö törésmutató változás 20 kettősrétegü, $B T S$-nal egyszer kezelt $\mathrm{ZnO}_{2} / P S S$ mintán, az elsö minimum helyen $(\lambda=459 \mathrm{~nm})$, valamint a gözkoncentráció és hömérséklet értéke a kísérlet időtartama alatt 


\section{BTS -nal egyszer kezelt minta, második minimum helyen, vízgőz adszorpció:}

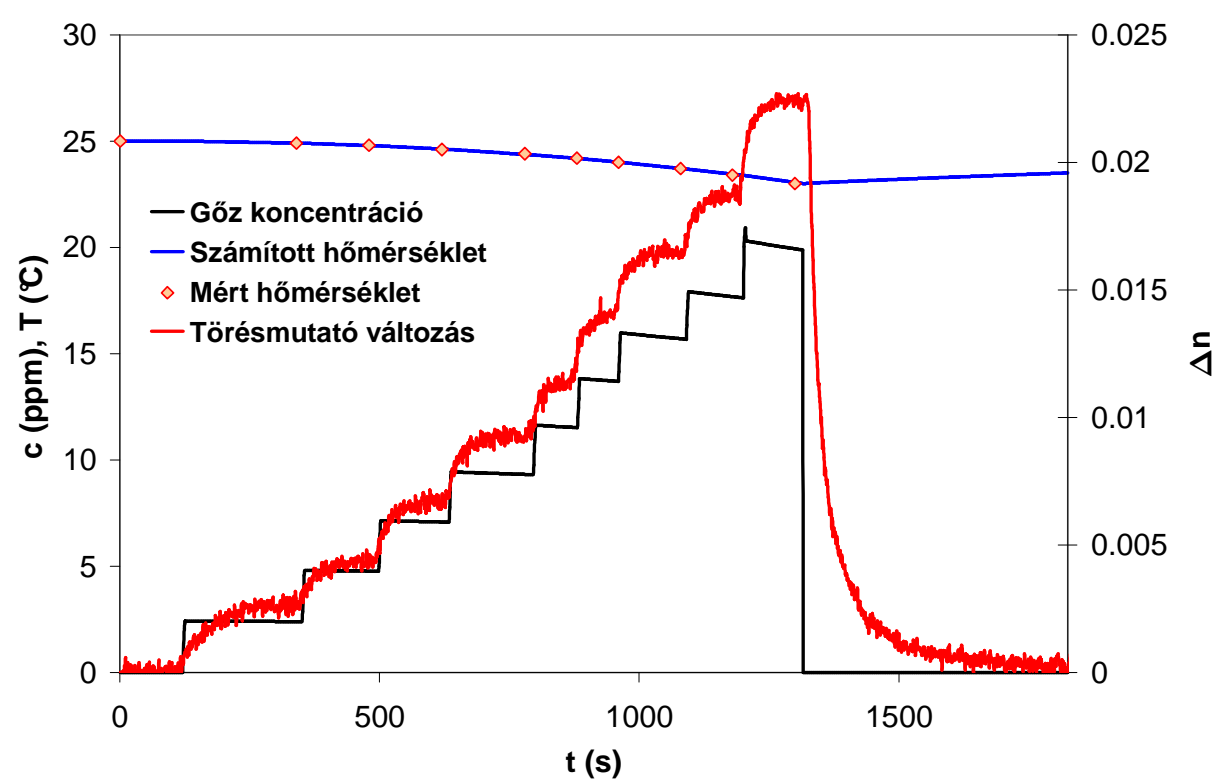

87. ábra Vizgőz hatására bekövetkezö törésmutató változás 20 kettösrétegü, $B T S$-nal egyszer kezelt $\mathrm{ZnO}_{2} / P S S$ mintán, a második minimum helyen $(\lambda=743 \mathrm{~nm})$, valamint a gözkoncentráció és hömérséklet értéke a kísérlet időtartama alatt
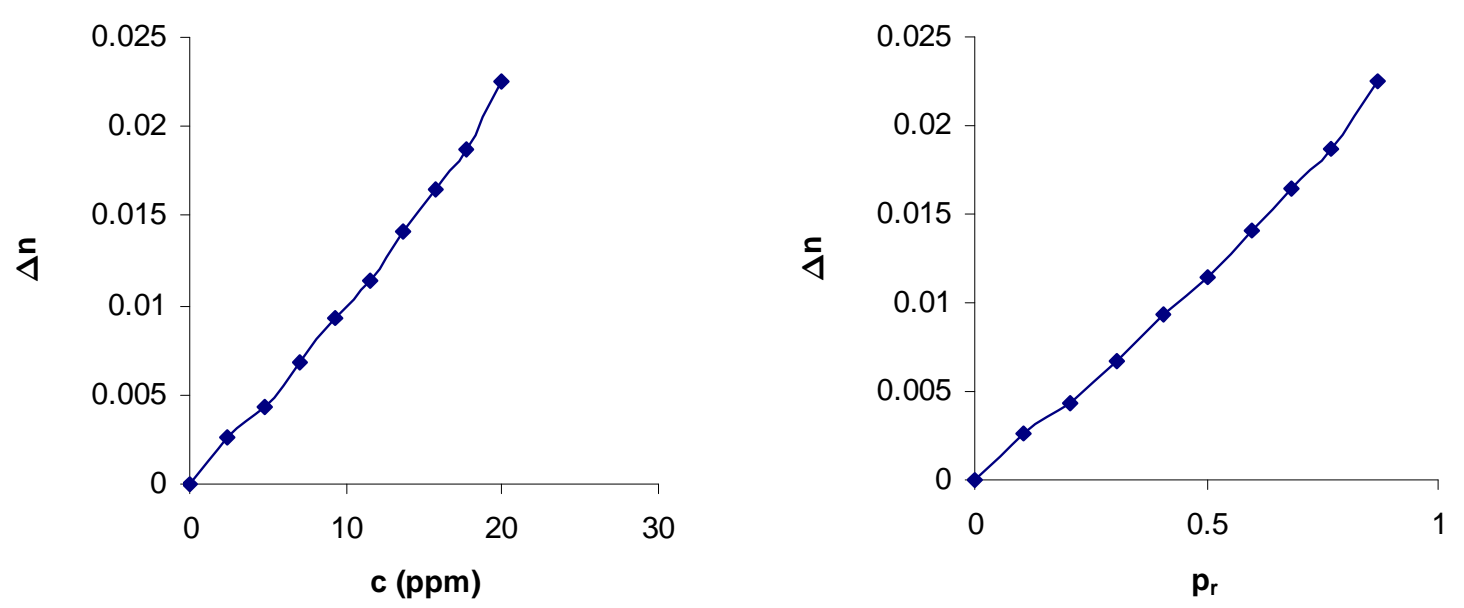

88. ábra Törésmutató változás a koncentráció ill. a relatív göznyomás függvényében, a második minimum helyen $\left(\lambda=743 \mathrm{~nm}\right.$ ), 20 kettösrétegü, BTS -nal kezelt $\mathrm{ZnO}_{2} / P S S$ mintán, vízgöz jelenlétében 


\section{BTS -nal egyszer kezelt minta, első minimum helyen, etanol adszorpció:}

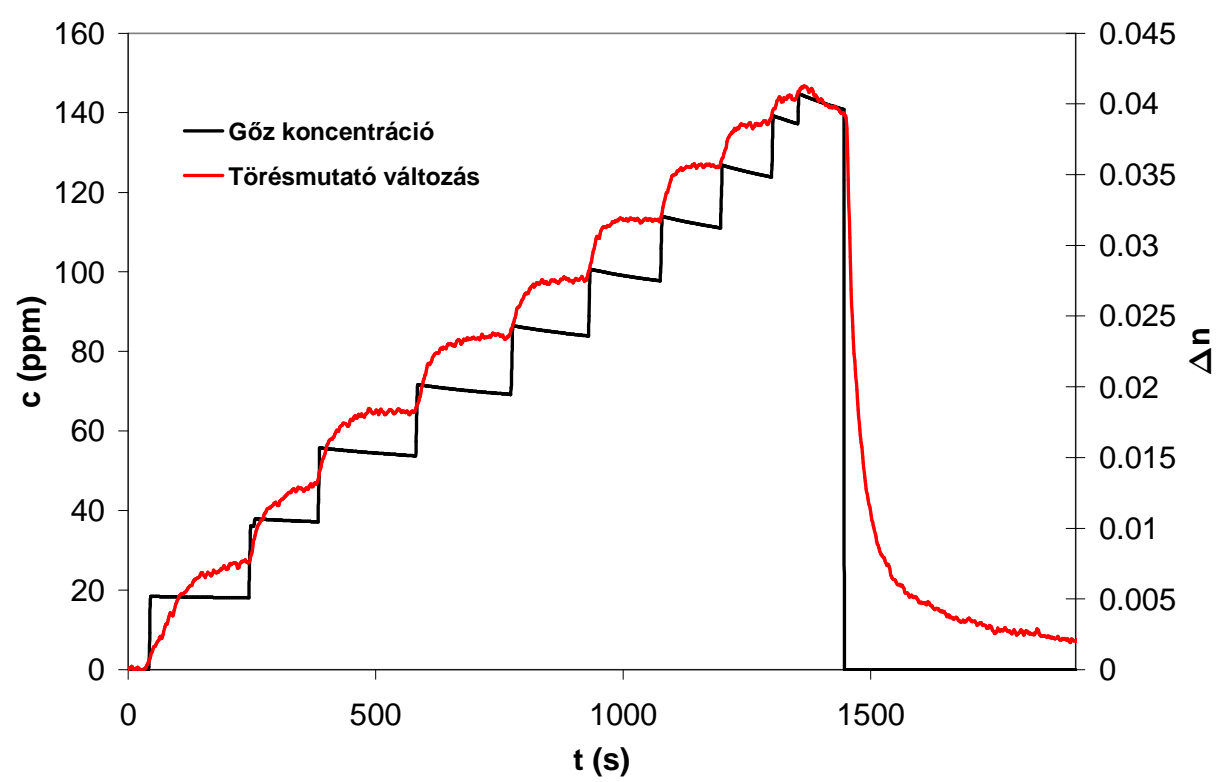

89. ábra Etanol göz hatására bekövetkezö törésmutató változás 20 kettösrétegü, $B T S$-nal kezelt $\mathrm{ZnO}_{2} / \mathrm{PSS}$ mintán, az elsö minimum helyen ( $\lambda=459 \mathrm{~nm}$ ), valamint a gözkoncentráció értéke a kísérlet idötartama alatt

\section{BTS -nal egyszer kezelt minta, második minimum helyen, etanol adszorpció:}

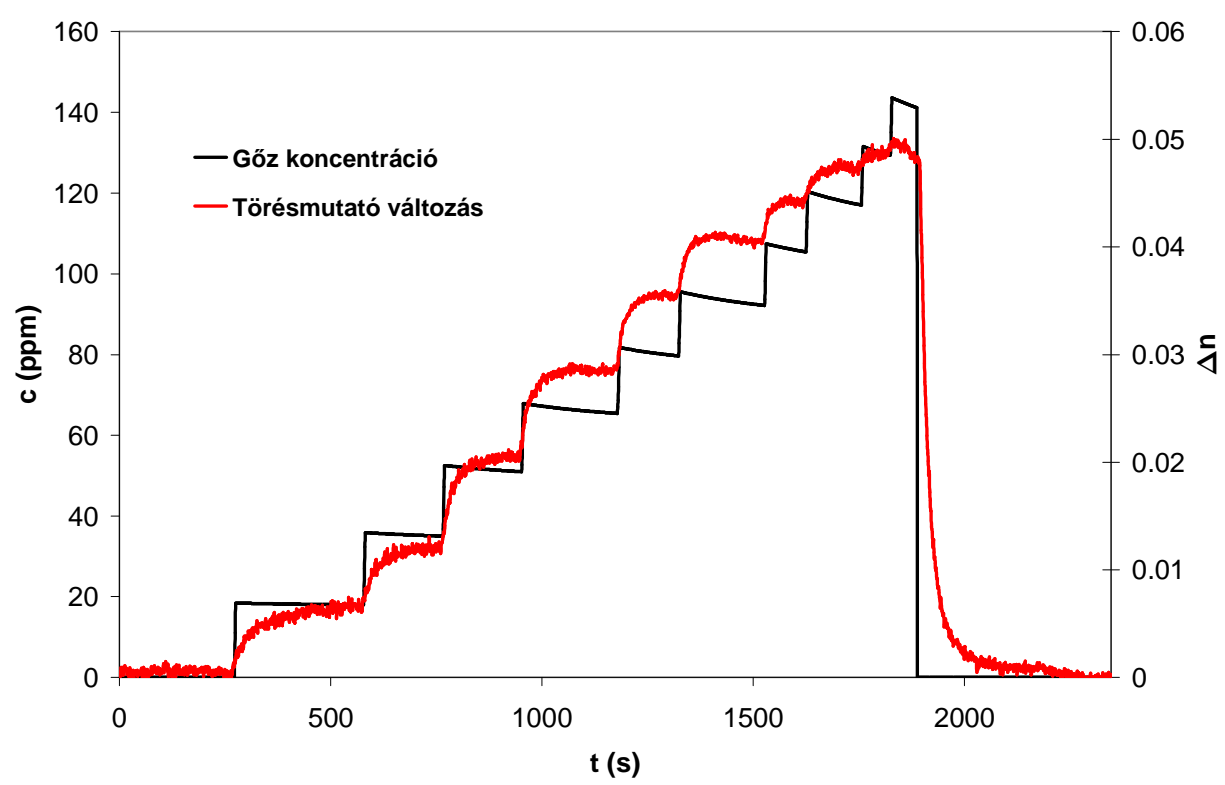

90. ábra Etanol göz hatására bekövetkezö törésmutató változás 20 kettösrétegü, BTS -nal kezelt $\mathrm{ZnO}_{2} / \mathrm{PSS}$ mintán, a második minimum helyen $(\lambda=743 \mathrm{~nm})$, valamint a gözkoncentráció értéke a kísérlet időtartama alatt 

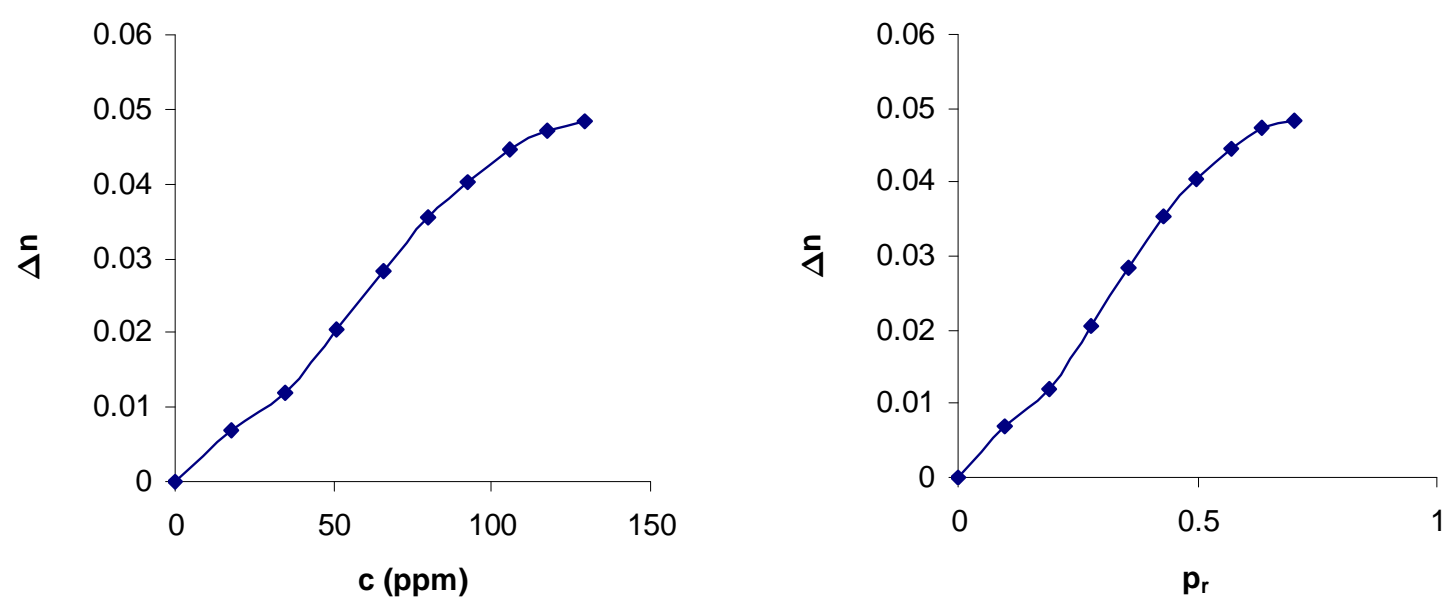

91. ábra Törésmutató változás a koncentráció ill. a relatív göznyomás függvényében, a második minimum helyen ( $\lambda=743 \mathrm{~nm}$ ), 20 kettösrétegü, BTS -nal kezelt $\mathrm{ZnO}_{2} / \mathrm{PSS}$ mintán, etanol göz jelenlétében

\section{BTS -nal egyszer kezelt minta, elsô minimum helyen, hexán adszorpció:}

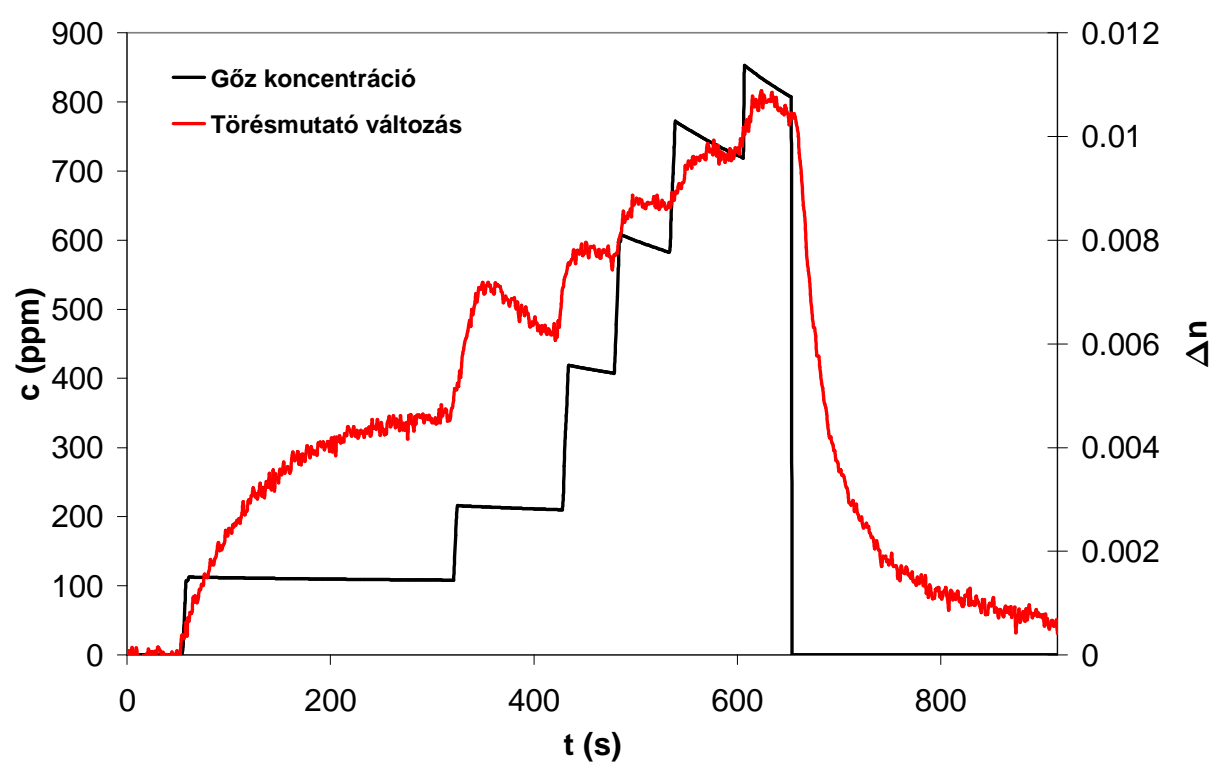

92. ábra Hexán göz hatására bekövetkezö törésmutató változás 20 kettősrétegü, BTS-sel kezelt $\mathrm{ZnO}_{2} / \mathrm{PSS}$ mintán, az elsö minimum helyen ( $\lambda=459 \mathrm{~nm}$ ), valamint a gözkoncentráció értéke a kísérlet idötartama alatt 
12. BTS -nal egyszer kezelt minta, második minimum helyen, hexán adszorpció:

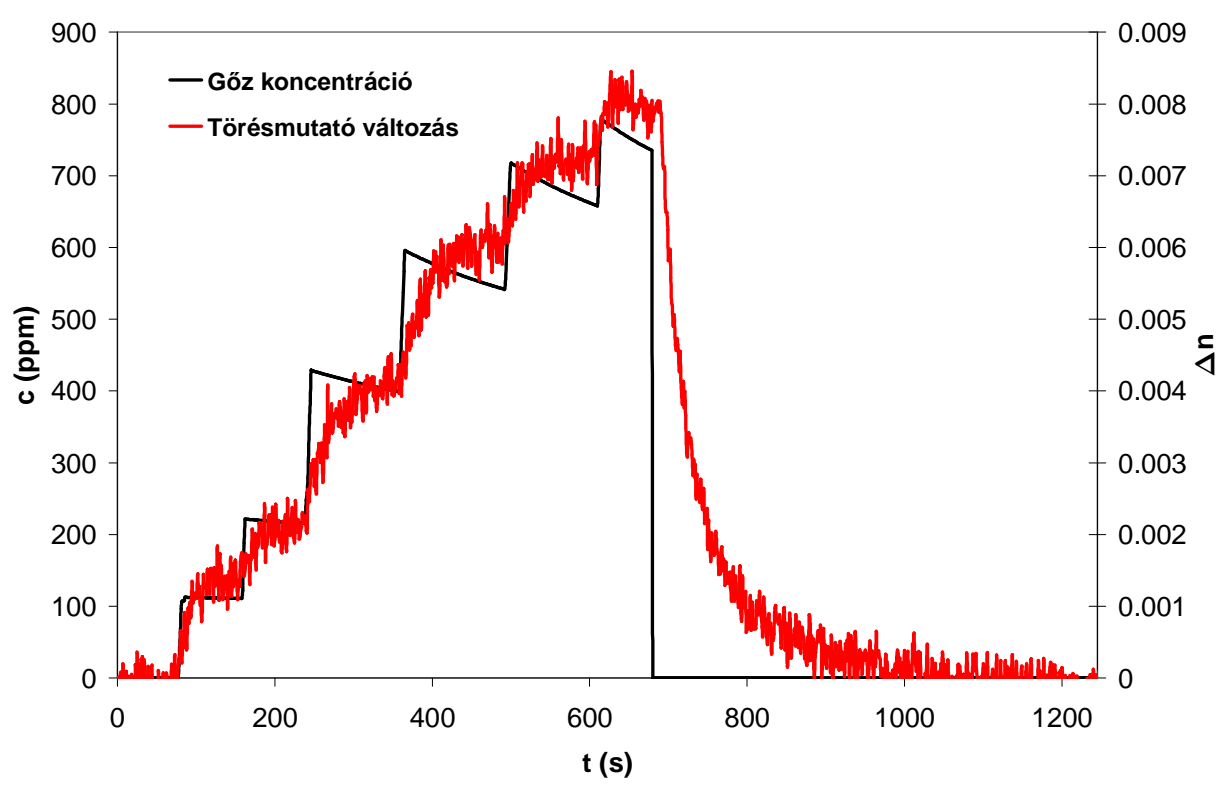

93. ábra Hexán göz hatására bekövetkezö törésmutató változás 20 kettősrétegü, BTS-sel kezelt $\mathrm{ZnO}_{2} / P S S$ mintán, a második minimum helyen $(\lambda=743 \mathrm{~nm})$, valamint a gözkoncentráció értéke a kísérlet idötartama alatt
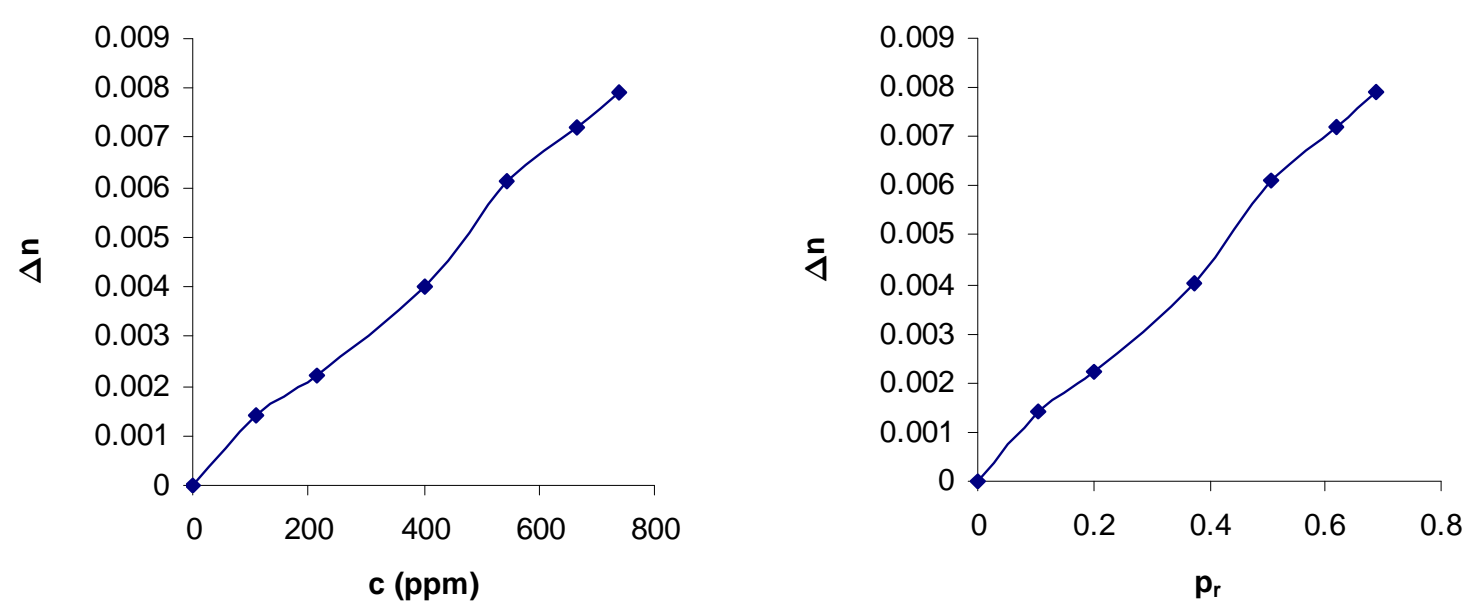

94. ábra Törésmutató változás a koncentráció ill. a relatív göznyomás függvényében, a második minimum helyen ( $\lambda=743 \mathrm{~nm}$ ), 20 kettösrétegü, BTS-sel kezelt $\mathrm{ZnO}_{2} / \mathrm{PSS}$ mintán, hexán göz jelenlétében 
13. BTS -nal kétszer kezelt minta, második minimum helven, vízgőz adszorpció:

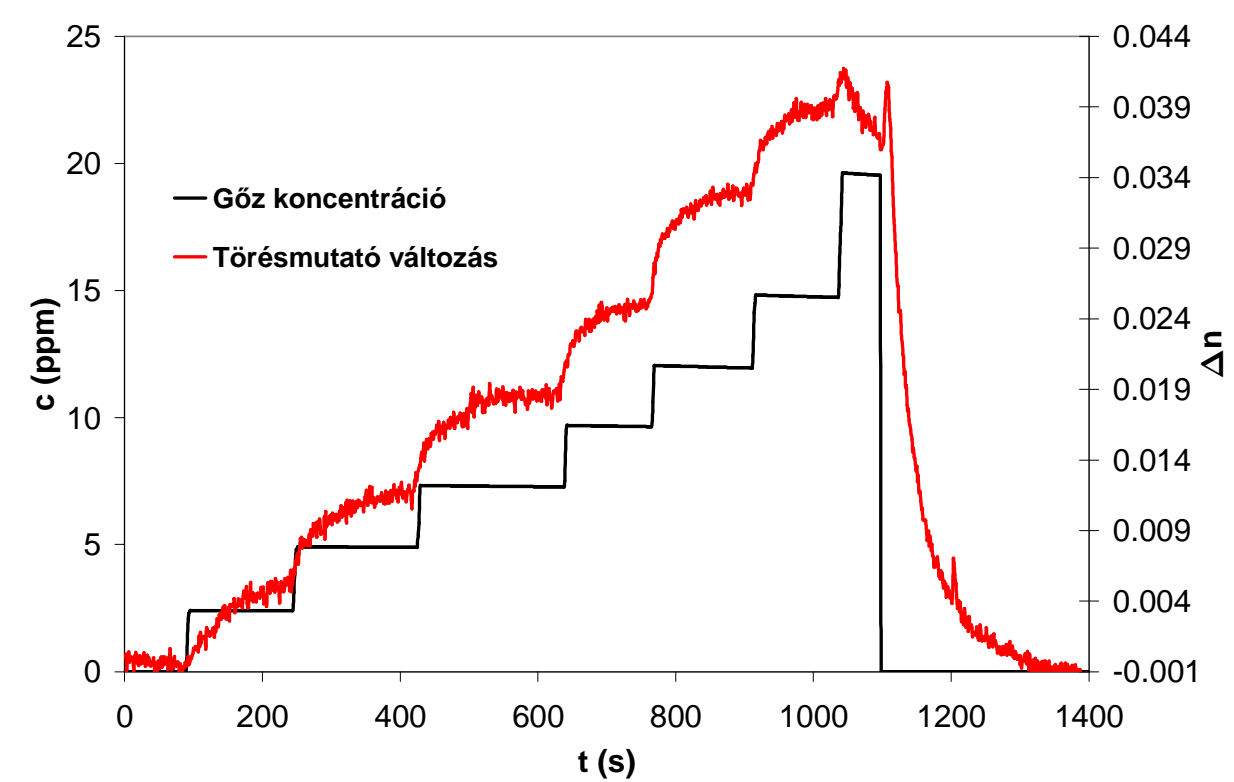

95. ábra Vizgőz hatására bekövetkezö törésmutató változás 20 kettösrétegü, BTS-sel kétszer kezelt $\mathrm{ZnO}_{2} / P S S$ mintán, a második minimum helyen $(\lambda=778 \mathrm{~nm})$, valamint a gözkoncentráció értéke a kísérlet időtartama alatt

\section{BTS -nal kétszer kezelt minta, második minimum helyen, etanol adszorpció:}

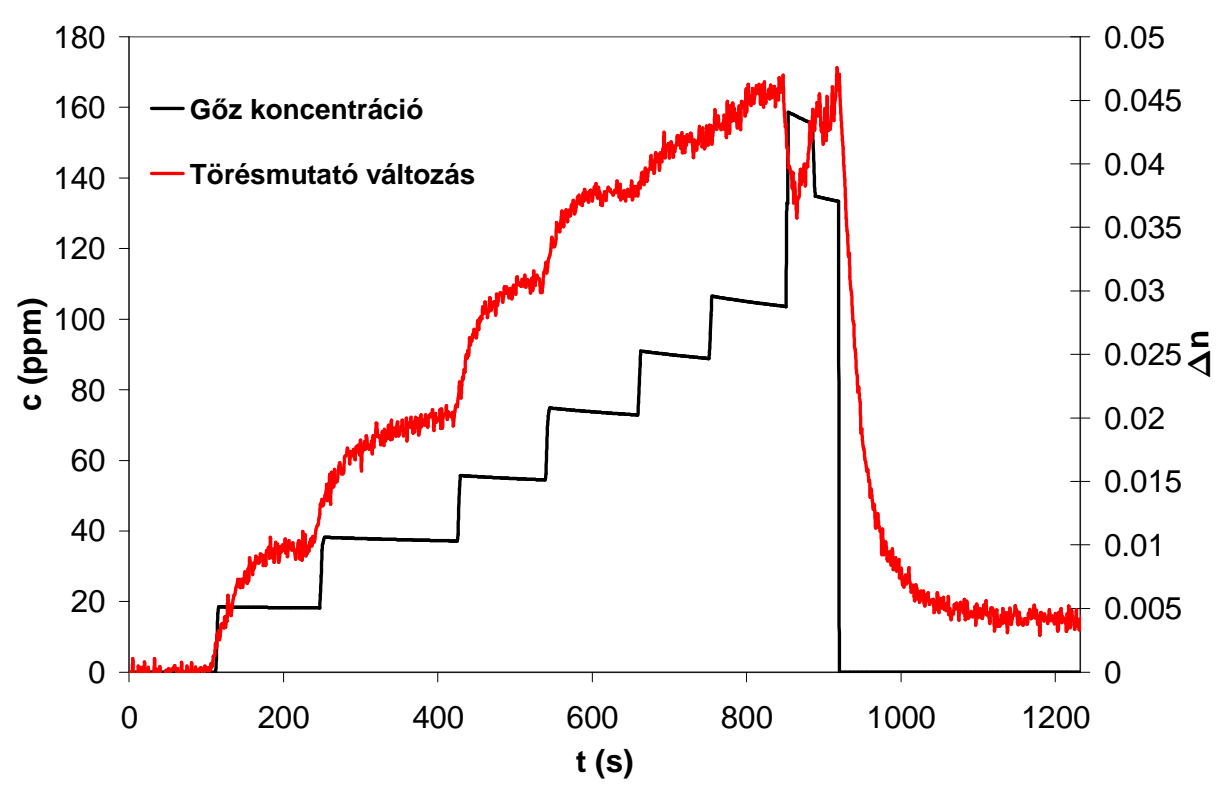

96. ábra Etanol göz hatására bekövetkezö törésmutató változás 20 kettösrétegü, BTS-sel kétszer kezelt $\mathrm{ZnO}_{2} / P S S$ mintán, a második minimum helyen $(\lambda=778 \mathrm{~nm}$ ), valamint a gözkoncentráció értéke a kísérlet időtartama alatt 
15. BTS -nal kétszer kezelt minta, második minimum helyen, hexán adszorpció:

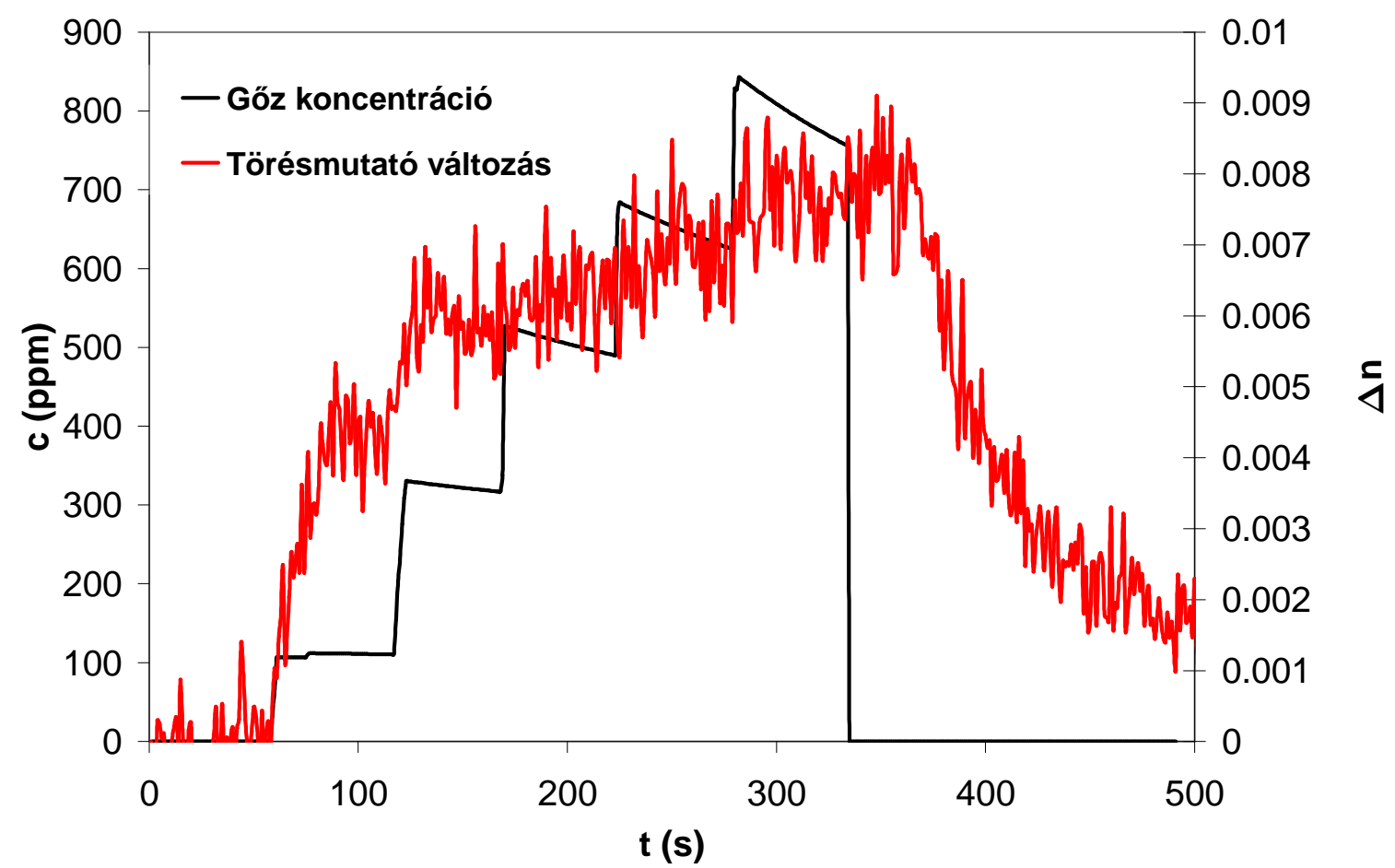

97. ábra Hexán göz hatására bekövetkezö törésmutató változás 20 kettősrétegü, BTS-sel kétszer kezelt $\mathrm{ZnO}_{2} / \mathrm{PSS}$ mintán, a második minimum helyen $(\lambda=778 \mathrm{~nm})$, valamint a gözkoncentráció értéke a kísérlet időtartama alatt 


\section{3. számú függelék - Az oktántiollal borított arany}

\section{nanorészecskékkel (OT-AuNR) módosított $\mathrm{ZnO}_{2} /$ PSS hibrid}

vékonyrétegen végzett mérési eredmények részletezése

\section{Eredeti minta, második minimum helyén, vízgőz adszorpció:}

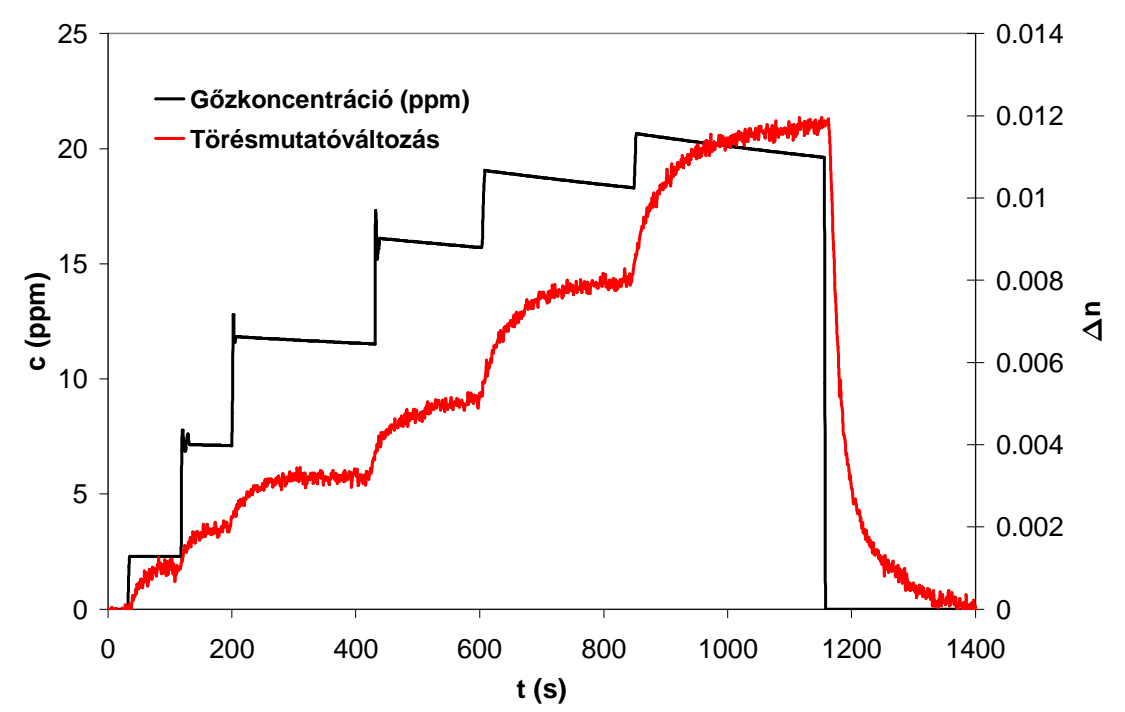

98. ábra Vizgöz hatására bekövetkezö törésmutató változás 20 kettösrétegü, eredeti $\mathrm{ZnO}_{2} / P S S$ mintán, a második minimum helyen $(\lambda=653 \mathrm{~nm}$ ), valamint a gözkoncentráció értéke a kísérlet időtartama alatt

\section{Eredeti minta, második minimum helyén, hexán adszorpció:}

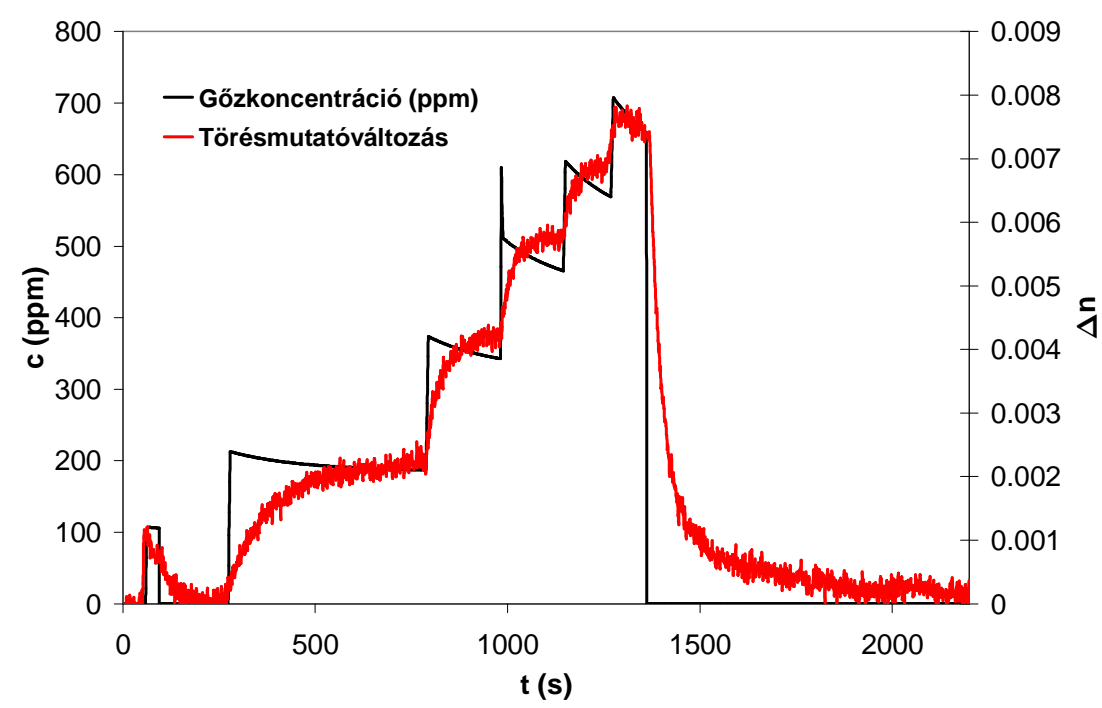

99. ábra Hexán gőz hatására bekövetkező törésmutató változás 20 kettősrétegü, eredeti $\mathrm{ZnO}_{2} / P S S$ mintán, a második minimum helyen $(\lambda=653 \mathrm{~nm}$ ), valamint a gőzkoncentráció értéke a kísérlet időtartama alatt 


\section{OT-AuNR -kel módosított minta, második minimum helyén, vízgőzz adszorpció:}

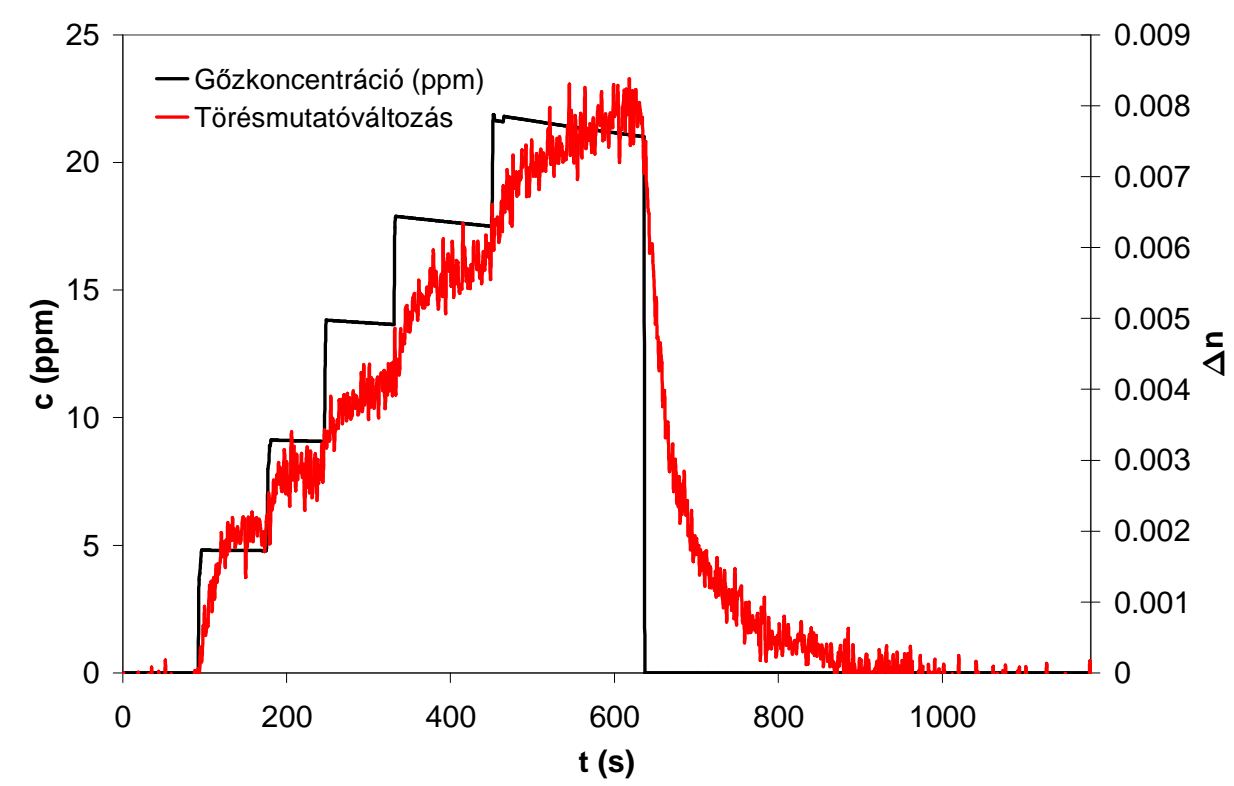

100. ábra Vízgőz hatására bekövetkezö törésmutató változás 20 kettösrétegü,

OT-AuNR-rel egyszer kezelt $\mathrm{ZnO}_{2} / \mathrm{PSS}$ mintán, a második minimum helyen ( $\lambda=664 \mathrm{~nm}$ ), valamint a gözkoncentráció értéke a kísérlet időtartama alatt

\section{OT-AuNR -kel módosított minta, második minimum helyén, hexán adszorpció:}

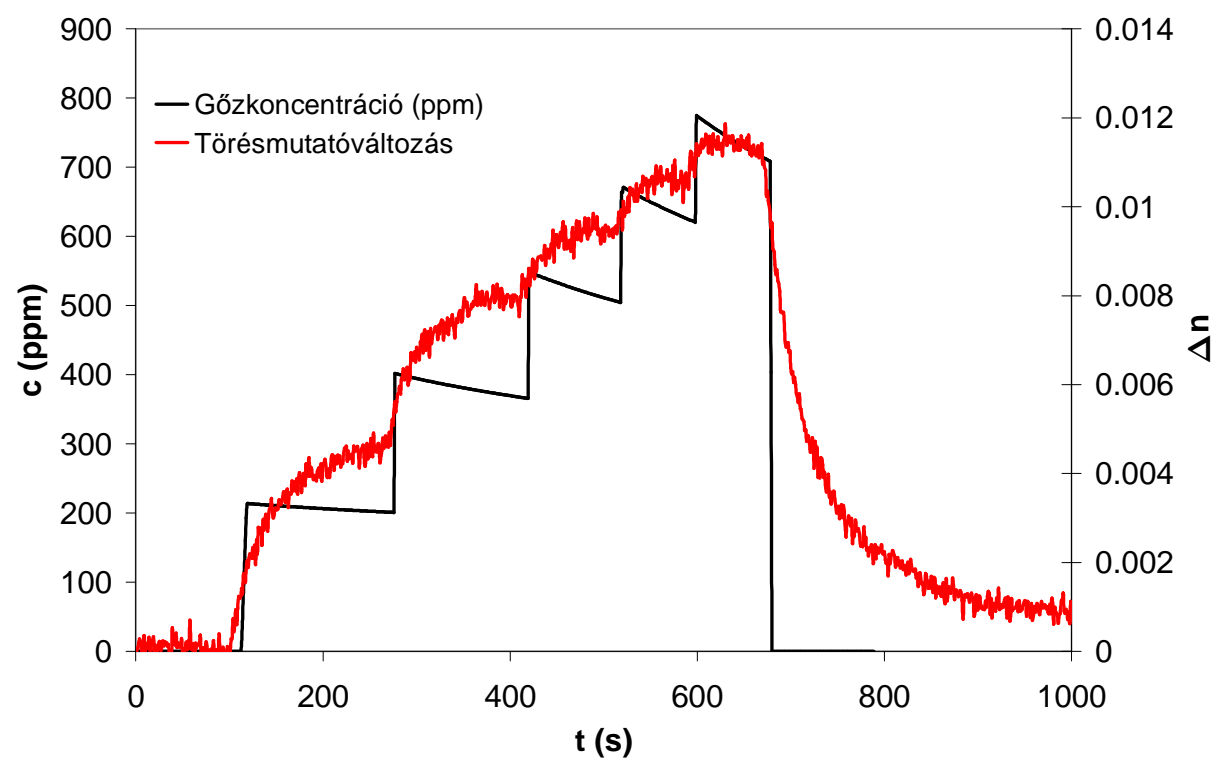

101. ábra Hexán göz hatására bekövetkezö törésmutató változás 20 kettősrétegü, OT-AuNR-rel egyszer kezelt $\mathrm{ZnO}_{2} / \mathrm{PSS}$ mintán, a második minimum helyen ( $\lambda=664 \mathrm{~nm}$ ), valamint a gözkoncentráció értéke a kísérlet időtartama alatt 
5. OT-AuNR -kel kétszer módosított minta, második minimum helyén, vízgőz adszorpció:

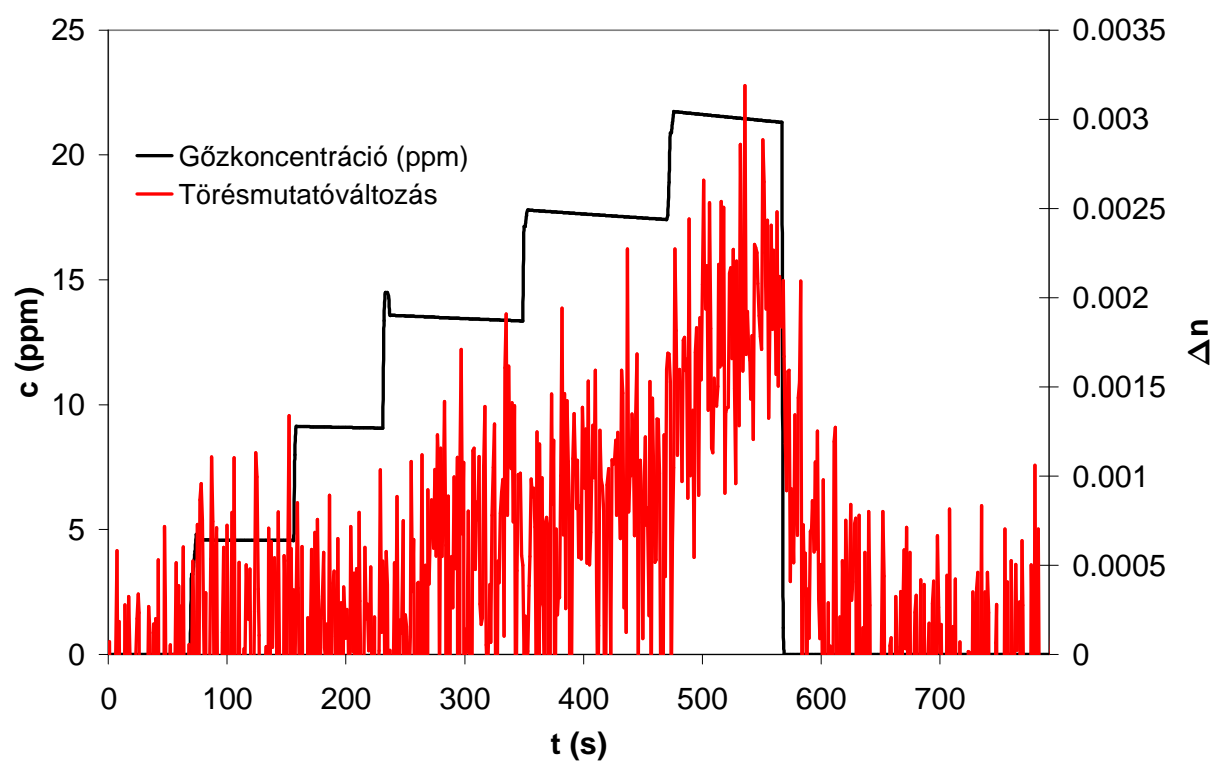

102. ábra Vízgőz hatására bekövetkezö törésmutató változás 20 kettösrétegü,

OT-AuNR-rel kétszer kezelt $\mathrm{ZnO}_{2} / P S S$ mintán, a második minimum helyen ( $\left.\lambda=688 \mathrm{~nm}\right)$, valamint a gözkoncentráció értéke a kísérlet idötartama alatt

\section{OT-AuNR -kel kétszer módosított minta, második minimum helyén, hexán} adszorpció:

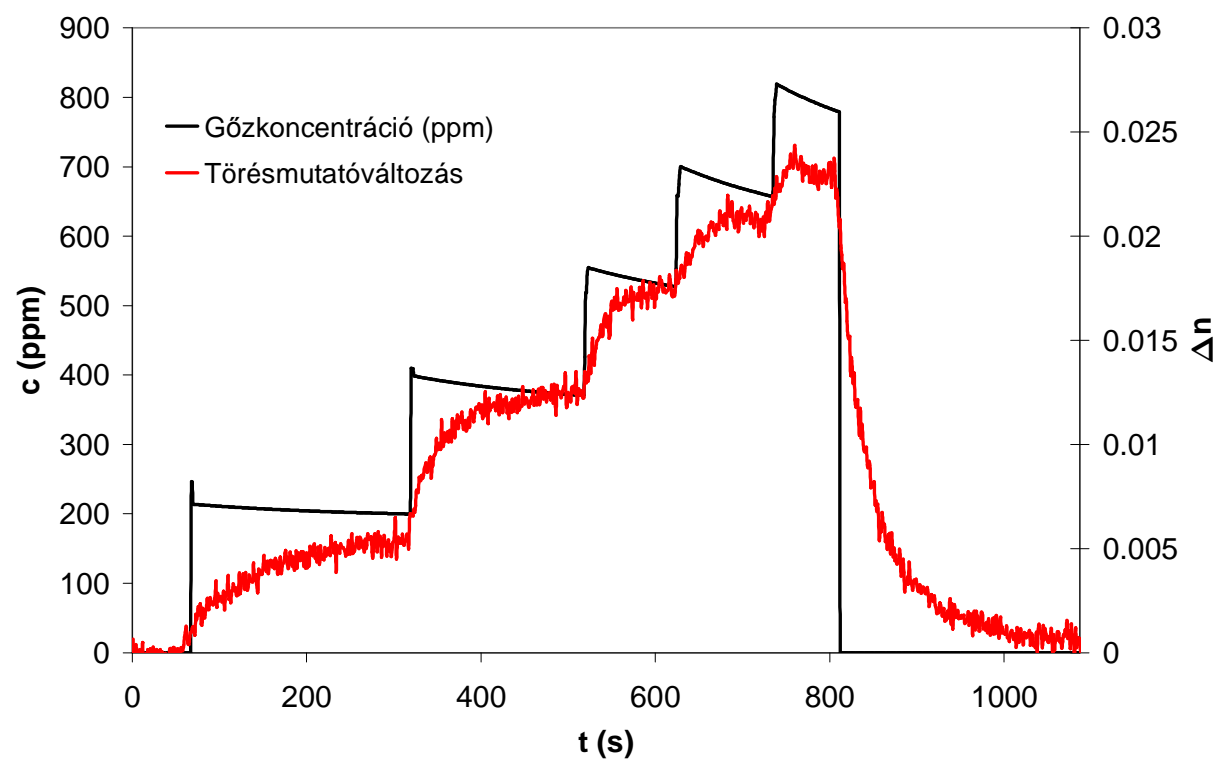

103. ábra Hexán göz hatására bekövetkezö törésmutató változás 20 kettösrétegü, OT-AuNR-rel kétszer kezelt $\mathrm{ZnO}_{2} / P S S$ mintán, a második minimum helyen ( $\lambda=688 \mathrm{~nm}$ ), valamint a gözkoncentráció értéke a kísérlet időtartama alatt 


\section{Summary}

In first part of present work zinc peroxide nanoparticles were prepared in water. Photolysis of zinc acetate dyhydrate in aqueous medium leads to the formation of $\mathrm{ZnO}_{2}$ nanoparticles with a diameter range of $15-60 \mathrm{~nm}$, with increasing size during the synthesis. I investigated the optical and structural properties of the prepared nanoparticles, I determined their size and studied their thermal decomposition and surface charge. During high temperature heat treatment $\left(\mathrm{T}>210^{\circ} \mathrm{c}\right)$ there is a structural change of zinc peroxide, and the result of thermal degradation are $\mathrm{ZnO}$ particles. The heat treatment $\left(200-800{ }^{\circ} \mathrm{C}\right)$ results a systematical size change from $15 \mathrm{~nm}$ to $60 \mathrm{~nm}$ (calculated by Debye-Scherrer equation).

I prepared porous hybrid thin films from the positively surface charged $\mathrm{ZnO}_{2}$ particles and negative surface charged binding materials (PSS, poly(styrenesulfonate) as polyelectrolyte, and Na-hectorite as layered silicate) by "Layer-by-Layer Self Assembly" method on the surface of solid substrate. The $400{ }^{\circ} \mathrm{C}$ heat treatment of $\mathrm{ZnO}_{2} / \mathrm{Na}$-hektorit thin films resulted thin layers containing $\mathrm{ZnO}$ by the thermal degradation of zinc peroxide. For the preparation I used $0.85 \% \mathrm{ZnO}_{2}$ colloidal solution, $0.1 \%$ Na-hectorite suspension and $0.01 \%$ solution of PSS. Determination of specific surface charge had importance in the choice of the concentration of the layer creating components for which I used streaming potential measurements to optimize the ratio of builder components. I found that using $0.005 \%$ PSS solution and 0,05\% Na-hectorite suspension (1: 10 charge) for preparation resulted a nonuniform build-up (the absorbance measured at the same wavelength increased nonlinear with layer number), or the system saturated before reaching the wanted layer number, because the electrostatic attractiveness required to alternating build-up was to low (from binder). Using $0.05 \%$ PSS solution and $0.02 \%$ Na-hectorite suspension (1:1 and 1:1.25 charge ratio) also resulted the saturation of electrostatic forces (compensating the surface charge of the zinc peroxide particles), and/or due to the high quantity of binder the layers became opaque with high light scattering. Using $0.01 \%$ solution of PSS or $0.1 \%$ Na-hectorite (charge ratio of 1:5) the layers were well-ordered and absorbance increased linear, so I have determined, that the optimal charge ratio is 1:5 (between zinc peroxide and binder components), therefore, in the course of my work, this ratio was used.

I studied the build-up of thin layers by UV-visible absorption and reflectance spectrophotometry and quartz crystal microbalance (QCM). The structural properties were investigated by X-ray diffraction, the morphology was studied by atomic force microscopy 
(AFM) and scanning electron microscopy (SEM). The bandgap energy in semiconductors also appears in nanoparticles, thus also in thin layers. I have determined that in the case of zinc peroxide/Na-hectorite thin layers the energy of the bandgap remained independent of the number of layers, it is a constant $3.98 \mathrm{eV}$, because the particles intercalated between the silicate lamellae are in so called confined space. This property is also characteristic of $\mathrm{ZnO} / \mathrm{Na}$-hectorite films, but according to the phase transition it changes to the value of $3.2 \mathrm{eV}$. In the case of the polymer films the bandgap energy is decreasing with layer number from 4.12 to $3.74 \mathrm{eV}$. This is possible because the polymer chains are able to bind to the surface of the particles and size quantization effect can dominate at low layer numbers. But at higher layer numbers the effect is weakening, so the bandgap energy decreases to the value of bulk phase.

Other aim of the work was to develop a profiling method to measure and calculate the optical properties of hybrid thin films, mainly the refractive index (as the function of wavelength) and layer thickness. The latter's importance lies in the fact that in the presence of gases, vapors the spectrum of the films is shifting toward the higher wavelength range because of the increasing refractive index. I have developed a technique that calculates the refractive index by fitting analytical (trigonometrical) functions onto the measured curves (the sensorial importance of that appears later at the real-time determination of refractive index change). For the calculation of the optical parameters three cascading model is applied. In the 1) solid state model I used three components: a solid component with a wavelength-dependent refractive index (particles), a solid component with constant refractive index (binder) and pores with constant refractive index, which value is set to air's value. The thin layer was homogenized by the 2) effective medium model, which has two component also in the simplest case with surface roughness. As a result, I received a constant layer thickness with a homogeneous refractive index. I chose the effective medium approximation called Bruggeman model extended to three component. This is one of the most common model, on the other hand, it is easily built into the computer system evaluation software. The 3) wave propagation model determines the equations used for describe the ray propagation in the thin film. I used two-ray interference model which I summarized by complex amplitude method. The other beams of light increase the intensity but does not change the location of extrema on the curves. Using the three models above cascading at the same time, I received an equation between the wavelength and reflected intensity. Using the resulting equation in a simulation software based on the best match I could determine the effective index of refraction and layer thickness. 
In addition to the traditional layer-by-layer immersion technique I prepared zinc peroxide/cross-linked polymer hybrid thin films by combining the method with photopolymerization. The poly(acrylamide) and poly( $\mathrm{N}$-isopropyl-acrylamide) (as hydrogels) carried different properties in the course of the bulk phase experiments: PAAm carried hydrophilic, while the PNIPAAm predominantly hydrophobic properties. By Fouriertransform infrared absorption spectroscopy was proved that $\mathrm{ZnO}_{2}$ /acrylamide and $\mathrm{ZnO}_{2} / \mathrm{N}$-isopropyl-acrylamide hybrid films became polymerized $\mathrm{ZnO}_{2} /$ poly (AAm) and poly(NIPAAm) thin layers after the adsorption of cross-linking agent and irradiation with UV light. Water and ethanol adsorption experiments were done to investigate the similar or different properties of the cross-linked polymers in thin films. I have found that the specific adsorbed amount decreased in all cases as a result of polymerization. This is explained by the fact that while many of the binding location of the monomers are available for water and ethanol molecules, until many of them disappears during the polymerization. Only in case of adsorbed ethanol amount was observed benefit of the poly(acrylamide) polymerized form. The partially hydrophilic/hydrophobic hybrids adsorbed almost equal amount of water and ethanol, significantly larger quantities of water was adsorbed by the hydrophilic thin layers based on acrylamide. The results are in good accordance with the data received at bulk phase. My further goal was to investigate the applicability of thin layers as sensors in a selfdeveloped flow system, in presence of vapors with different polarity. I have determined that the reflection spectra of the prepared $\mathrm{ZnO}_{2} / \mathrm{PSS}$ hybrids shifts toward the higher wavelengths if they are in atmosphere that contains water or ethanol vapor. Using this phenomenon I have developed a sensor based on the change of optical properties for the detection and characterization of the adsorption of vapors. A light source, a liquid holder unit with temperature control, a gas mixer containing vapor dosing unit, a sample holder and a photometer as detector are the parts of the four-channel gas-flow sensor system. The system is capable to record reflection spectra in every second second, and to converts the wavelength shift to the change of the refractive index. One of the cornerstones of the measurements is find the minimum intensity location in the curves, because the noise level exceeds many times the value of the intensity difference at two neighboring pixels, thus finding the right value can be missed easily. To find the right values I used nine degree polynomial fitting of reflection curves and it resulted a high quality smoothing in the monitoring of minimum wavelengths. measurement data. The specific adsorbed amount was determined from the refractive index change after calibrating with quartz crystal microbalance. The $\mathrm{ZnO}_{2} / \mathrm{PSS}$ hybrid films were modified by butyl trichlorosilane and gold nanoparticles covered by octanethiol to increase 
the specific sensitivity and hydrophobicity. I found in the course of surface modifying by butyl trichlorosilane that the surface became hugely sensitive for the vapor of ethanol. After modification the specific adsorbed amount of ethanol was nine times higher than the original, while water amount only tripled, so the quantity of adsorbed ethyl alcohol were four times higher than water quantity. The adsorption of the hexane has not changed significantly as a result of the surface treatment. The treatment by gold nanoparticle covered by octanethiol caused that the surface became completely hydrophobic, the adsorbed water vapor amount decreased significantly, while the amount of adsorbed hexane tripled, thus 28 times higher refractive index change was observed in the case of hexane adsorption as water vapor. 


\section{Köszönetnyilvánítás}

Hálás köszönettel tartozom témavezetőmnek, Prof. Dr. Dékány Imre akadémikus Úrnak, amiért munkám során megszámlálhatatlan elméleti és gyakorlati tanácsokkal látott el, valamint a szakmai beszélgetésekért, amik nélkülözhetetlennek bizonyultak egy fizikus számára, hogy eligazodjon a „kolloidika” berkeiben. Köszönöm továbbá, hogy lehetővé tette számomra, hogy számos nemzetközi konferencián gyarapítsam tudásomat.

Köszönettel tartozom Ráczné Kuhn Klárának, Ábrahám Nórának és Dr. Janovák Lászlónak a számos szakmai segítségért, és legfőképpen a baráti támogatásért, amivel mind szakmailag, mind emberileg átsegítettek a nehéz perceken.

Köszönöm a (volt) Kolloidkémiai Tanszék minden munkatársának, és Dr. Kákonyi Róbertnek, akik baráti és szakmai támogatásukkal segítettek a dolgozat elkészítésében.

Végül, de nem utolsó sorban köszönettel tartozom testvéremnek, páromnak, és családjaiknak, akik mindvégig mellettem álltak és türelmükkel, szeretetükkel nyugodt hátteret biztosítottak a munkámhoz,

és Édesanyámnak, aki rövid élete során a legmélyebb szeretettel felnevelt, embert faragott belölem, és gondoskodóan terelt arra az útra, amelyen ebben a pillanatban is járok. 


\section{Tudományos közlemények}

\section{Az értekezés témájához kapcsolódó tudományos dolgozatok}

1. Dániel Sebők, László Janovák, Imre Dékány

Optical, structural and adsorption properties of zinc peroxide/hydrogel nanohybrid films Applied Surface Science 256 (2010) 5349-5354

IF $_{2010}: 1.793$

2. Dániel Sebők, Tamás Szabó, Imre Dékány

Optical properties of zinc peroxide and zinc oxide multilayer nanohybrid films

Applied Surface Science 255 (2009) 6953-6962

IF 2009: 1.616

3. Edit Pál, Dániel Sebők, Viktória Hornok, Imre Dékány

Structural, optical, and adsorption properties of $\mathrm{ZnO}_{2} /$ poly(acrylic acid) hybrid thin porous films prepared by ionic strength controlled layer-by-layer method

Journal of Colloid and Interface Science 332 (2009) 173-182

IF $_{2009}: 3.019$

4. Dániel Sebők, Krisztina Szendrei, Tamás Szabó, Imre Dékány

Optical properties of zinc oxide ultrathin hybrid films on silicon wafer prepared by layer-bylayer method

Thin Solid Films 516 (2008) 3009-3014

IF $_{2008}: \mathbf{1 . 8 8 4}$

5. Dániel Sebők, Imre Dékány

Sensorial application of zinc peroxide ultrathin hybrid films with modified surfaces for detection of ethanol and n-hexane vapours

Nanotechnology: Sensing and actuating (közlésre beadva, 2012)

$I F_{2010}: 3.652$

$\Sigma I F=8.312$

(11.964)

Az értekezés témájához részben vagy nem kapcsolódó tudományos dolgozatok

6. N. Ábrahám, D. Sebők, Sz. Papp, L. Körösi, I. Dékány

Two-dimensional arrangement of monodisperse $\mathrm{ZnO}$ particles with Langmuir-Blodgett technique

Colloids and Surfaces A: Physicochemical and Eng. Aspects 384 (2011) 80-89

$I F_{2010}: 2.130$

7. Edit Pál, Viktória Hornok, Dániel Sebők, Andrea Majzik, Imre Dékány Optical and structural properties of protein/gold hybrid bio-nanofilms prepared by layer-by-layer method Colloids and Surfaces B: Biointerfaces 79 (2010) 276-283

$I F_{2010}: 2.780$ 
8. Cs. Vass, D. Sebők, B. Hopp

Comparing study of subpicosecond and nanosecond wet etching of fused silica

Applied Surface Science 252 (2006) 4768-4772

$I F_{2006}: 1.436$

\section{Összesített hatástényező: 14.658}

(18.31)

\section{Konferencia részvételek}

\section{Előadások}

1. I. Dékány, R. Kun, E. Pál, L. Körösi, K. Szendrei, D. Sebők

Optical and photocatalytical properties of $\mathrm{ZnO}$ and $\mathrm{ZnAl}$ double hydroxide nanoparticles stabilized in ultrathin films by LbL method

$12^{\text {th }}$ International Conference on Surface and Colloid Science (IACIS), Peking, 2006. október $15-20 .$, p. 22

\section{I. Dékány, E. Pál, V. Hornok, T. Aradi, D. Sebők}

Nanostructured ultrathin hybrid layers prepared by LBL method

COST D43 Meeting, Cracow, Poland, 2007. március 18-21.

3. Dániel Sebők, Krisztina Szendrei and Imre Dékány

Changing of optical properties of $\mathrm{Zn}(\mathrm{OH})_{2}$ / polymer nanofilms prepared by LbL method under various ethanol vapor pressure

9th Conference on Colloid Chemistry, 2007. október 3-5., Siófok, p. 62.

4. Daniel Sebők, Edit Pál, Robert Kun, Tamas Szabó, Judit Ménesi, Andrea Majzik, Viktoria Hornok, Imre Dékány

Functional and reactive surfaces prepared by layer-by-layer assembly of nanohybrid materials

22nd ECIS Conference and Workshop of Cost action D 43, 2008. augusztus 31- szeptember 05., Cracow, Poland, p. 58.

5. Sebők Dániel, Janovák László, Dékány Imre

In situ fotopolimerizációval elöállitott cink-peroxid / hidrogél hibrid vékonyrétegek optikai és adszorpciós tulajdonságainak vizsgálata

VII. Országos Anyagtud. Konferencia, Balatonkenese, 2009. október 11-13.

6. Dániel Sebők, Laszló Janovák and Imre Dékány

Optical and adsorption properties and sensorial application of thin films containing $\mathrm{ZnO}$ and $\mathrm{ZnO}_{2}$

2011. október 24., Kairó, Egyiptom

7. Imre Dékány, Tamás Szabó, Viktória Hornok and Dániel Sebők

Self-assembled nanohybrid thin films prepared from inorganic colloids, polyelectrolytes and proteins

Beyond Self-Assembly, 2012. január 22-25., Bad Gastein, Ausztria 


\section{Poszterek}

1. Dániel Sebők, Krisztina Szendrei and Imre Dékány

Changing of optical properties of $\mathrm{Zn}(\mathrm{OH})_{2}$ nanoparticles / layer silicate nanofilms prepared by LBL method under ethanol vapour

$20^{\text {th }}$ Conference of the European Colloid and Interface Society and $18^{\text {th }}$ European Chemistry at Interfaces Conference (ECIS-ECIC), Budapest, 2006. szeptember 17-22., p. 397

2. Krisztina Szendrei, Dániel Sebők, Tamás Szabó, and Imre Dékány Optical Properties of ZnO nanoparticles in ultrathin films prepared by LBL method.

$20^{\text {th }}$ Conference of the European Colloid and Interface Society and $18^{\text {th }}$ European Chemistry at Interfaces Conference (ECIS-ECIC), Budapest, 2006. szeptember 17-22., p. 399

\section{3. É. Bazsó, J. Ménesi, D. Sebők, N. Buzás, L. Reich, and I. Dékány}

Photocatalytic destruction of methylene blue and sudan red dyes in $\mathrm{TiO}_{2}$ suspensions and films

$20^{\text {th }}$ Conference of the European Colloid and Interface Society and $18^{\text {th }}$ European Chemistry at Interfaces Conference (ECIS-ECIC), Budapest, 2006.

4. Sebők Dániel, Patzkó Ágnes, Fodor Krisztina, Erdőhelyi András, Dékány Imre A metán adszorpciós tárolása

Szeged, Ipari Kapcsolatok Napja, 2006.

5. E. Pál, D. Sebők, R. Kun, V. Hornok, A. Majzik, I. Dékány

Layer-by-layer self-assembly of organic/inorganic colloids

Gordon Conference, Italy, 2007

6. A. Majzik, R. Patakfalvi, E. Pál, D. Sebők, I. Dékány

Surface functionalization and self-assembly of metal oxide and gold colloids

$21^{\text {th }}$ ECIS Conference, 2007. szeptember 10-15., Geneve, Switzerland

7. D. Sebők, L. Janovák, E. Pál, I. Dékány

Adsorption and reflection properties of functional hybrid nanofilms

22nd ECIS Conference and Workshop of Cost action D 43, 2008. augusztus 31- szeptember 05., Cracow, Poland, p. 606.

8. Edit Pál, Dániel Sebők, László Janovák, Imre Dékány

Self-assembled hybrid nanostuctured films

Workshop of Cost action D 43 „Functionalizes materials and Interfaces”,

2008. április 2-4., Berlin, Germany

9. Edit Csapó, Dániel Sebők, Viktória Hornok and Imre Dékány

Detection of gases/vapours and proteins on the surface of functionalized gold nanoparticles and thin layers

Euronanoforum 2011, 2011. május 30 - június 1., Budapest

10. D. Sebők, E. Csapó, J. Homola, I. Dékány

Immobilization of amino acids and proteins on pure and modified gold surface using Surface Plasmon Resonance (SPR) technique

$25^{\text {nd }}$ ECIS Conference, 2011. szeptember 4-9., Berlin, Németország 


\section{Irodalomjegyzék}

[1] Richard P. Feynman, There's plenty of room at the bottom: an invitation to open up a new field of physics, Caltech Engineering and Science 23:5 (1960) 22-36

[2] Hevesi Imre: Elektromosságtan I., JATE Press, Szeged (1995)

[3] N.N. Greenwood, A. Earnshaw, Elemek kémiája, Nemzeti Tankönyvkiadó, Budapest (1999)

[4] A. Hagfeldt, M. Grätzel, Light Induced redox reactions in nanocrystalline systems, Chem. Rev. 95 (1995) $52-$ 53

[5] L. Brus, Electronic wave functions in semiconductor clusters: Experiment and theory, J. Phys. Chem. 90 (1986) 2555-2560

[6] W. Chen, Y.H. Lu, M. Wang, L. Kroner, H. Paul, H.J. Fecht et al., Synthesis, thermal stability and properties of ZnO2 nanoparticles, J. Phys. Chem. C 113 (2009) 1320

[7] S. Lindroos, M. Leskela, Growth of zinc peroxide ( $\mathrm{ZnO}$ ) and zinc oxide ( $\mathrm{ZnO})$ thin films by the successive ionic layer adsorption and reaction - SILAR -technique, International Journal of Inorganic Materials 2 (2000) 197-201

[8] M. Akiba and A. S. Hashim, Vulcanization and crosslinking in elastomers, Progr. Pol. Sci. 22 (1997) 475521

[9] R. Hagel, K. Redecher, Patent US4363679-A (1981)

[10] X. Han, R. Liu, W. Chen, Z. X., Properties of nanocrystalline zinc oxide thin films prepared by thermal decomposition of electrodeposited zinc peroxide, TSF 516 (2008) 4025-4029

[11] R. B. Peterson, C. L. Fields, B. A. Gregg, Epitaxial chemical deposition of $\mathrm{ZnO}$ nanocolumns from NaOH solutions, Langmuir 20 (2004) 5114

[12] Lei Z. Zhang, Guo-Qing Tang, Preparation, characterization and optical properties of nanostructured ZnO thin films, Optical Materials 27 (2004) 217-220

[13] Y. Gu, I.L. Kuskovsky, M. Sin, S. O'Biran, G.F. Neumark, Quantum Confinement in ZnO Nanorods, Appl. Phys. Lett., 85 (2004) 3833-3835

[14] W. J.E. Beek, M.M. Wienk, M. Kemerink, X. Yang, R.A.J. Janssen, Hybrid zinc oxide conjugated polymer bulk heterojunction solar cells, J. Phys. Chem. B, 109 (2005) 9505-9516

[15] J.C. Lee, K.H. Kang, S.K. Kim, K.H.Yoon, I.J. Park, J. Song, RF sputter deposition of the high-quality intrinsic and n-type $\mathrm{ZnO}$ window layers for $\mathrm{Cu}(\mathrm{In}, \mathrm{Ga}) \mathrm{Se}$-2-based solar cell applications, Solar Energy Mat. \& Solar Cells 64 (2000) 185-195

[16] Y. Gao, M. Nagai, Morphology Evolution of ZnO Thin Films from Aqueous Solutions and Their Application to Solar Cells, Langmuir, 22 (2006) 3936-3940

[17] R. S. Mane, W.J. Lee, H. M. Pathan, S. H. Han, Nanocrystalline TiO2/ZnO thin films: Fabrication and application to dye-sensitized solar cells, J. Phys. Chem. B. 109 (2005) 24254

[18] F. Chaabouni, M. Abaab, B. Rezig, Metrological characteristics of ZNO oxygen sensor at room temperature, Sensors and Actuators B, 100 (2004) 200-204

[19] V. Musat, A.M. Rego, R. Monteiro, E. Fortunato, Microstructure and gas-sensing properties of sol-gel ZnO thin films, Thin Solid Films, 516 (2008) 1512-1515

[20] T.J. Hsueh, C.L. Hsu, Fabrication of gas sensing devices with $\mathrm{ZnO}$ nanostructure by the low-temperature oxidation of zinc particles, Sensors and Actuators B, 131 (2008) 572-576

[21] T.J. Hsueh, Y.W. Chen, S.J. Chang, S.F. Wang, C.L. Hsu, Y.R. Lin, I.C. Chen, ZnO nanowire-based CO sensors prepared on patterned $\mathrm{ZnO}: G a / \mathrm{SiO}_{2} / \mathrm{Si}$ templates, Sensors and Actuators B, 125 (2007) 498-503

[22] T.J. Hsueh, C.L. Hsu, S.J. Chang, I.C. Chen, Laterally grown ZnO nanowire ethanol gas sensors, Sensors and Actuators B, 126 (2007) 473-477

[23] P.K. Basu, P. Bhattachayya, N. Saha, H. Saha, S. Basu, The superior performance of the electrochemically grown ZnO thin films as methane sensor, Sensors and Actuators B, 133 (2008) 357-363 
[24] D.W. Bahnemann, C. Kormann, M.R. Hoffmann, Preparation and characterization of quantum size zinc oxide: a detailed spectroscopic study, J. Phys. Chem. 91 (1987) 3789-3798

[25] L. Spanhel, M.A. Anderson, Semiconductor clusters in the sol-gel process: quantized aggregation, gelation, and crystal growth in concentrated zinc oxide colloids, J. Am. Chem. Soc. 113 (1991) 2826-2833

[26] G. Rodriguez-Gattorno, P. Santiago-Jacinto, L. Rendon-Vázquez, J. Németh, I. Dékány, D. Diaz, Novel Synthesis Pathway of ZnO Nanoparticles from Spontaneous Hydrolysis of Zinc Carboxylate Salts, J. Phys. Chem. B. 107 (2003) 12597-12604

[27] J. Németh, G. Rodriguez-Gattorno, D. Diaz, A.R. Vázquez-Olmos, I. Dékány, Synthesis of ZnO Nanoparticles on a Clay Mineral Surface in Dimethyl Sulfoxide Medium, Langmuir 20 (2004) 2855

[28] J.F. Li, L.Z. Yao, C.M. Mo, W.L. Cai, Y. Zhang, L.D. Zhang, Photoluminescence enhancement of ZnO nanocrystallites with BN capsules, J. Crystal Growth 223 (2001) 535-538

[29] P. Liu, Facile preparation of monodispersed core/shell zinc oxide@polystyrene (ZnO@PS) nanoparticles via soapless seeded microemulsion polymerization, Coll. Surf. A: Physicochem. En. Aspects 291 (2006) 155-161

[30] P. K. Dutta, M. Jakupca, K. S. N. Reddy, L. Salvati, Controlled formation of microporous crystals from reverse micelles, Nature 374 (1995) 44-46

[31] A.P.A. Oliveira, J.F. Hochpied, F. Grillon, M.H. Berger, Controlled precipitation of zinc oxide particles at room temperature, Chem. Mat. 15 (2003) 3202-3207

[32] V. Skumryew, S. Stoyanov, Y. Zhang, G. Hadjipanayis, D. Givord, J. Nogues, Beating the superparamagnetic limit with exchange bias, Nature 423 (2005) 850-855

[33] B. Gorzolnik, P. Mela, M. Möller, Nano-structured micropatterns by combination of block copolymer selfassembly and UV photolithography, Nanotechnology 17 (2006) 5027-5032

[34] J. Yu, C. Li, S. Liu, Effect of PSS on morphology and optical properties of ZnO, J. Coll. Int. Sci. 326 (2008) $433-438$

[35] J. Liang, J. Liu, Q. Xie, S. Bai, W. Yu, Y. Qian, Hydrothermal Growth and Optical Properties of DoughnutShaped ZnO Microparticles, J. Phys. Chem. B, 109 (2005) 9463-9467

[36] U. Pal, P. Santiago, Controlling the morphology ZnO nanostructures through low temperature hydrothermal process, J. Phys. Chem. B, 109 (2005) 15317-15321

[37] Y. Ni, G. Wu, X. Zhang, X. Cao, G. hu, A. Tao, Z. Yang, X. Wei, Hydrothermal preparation, characterization and property research of flowerlike ZnO nanocrystals built up by nanoflakes, Mat. Res. Bull. 43 (2008) 2919-2928

[38] L. Ibarra, A. Marcos-Fernandez, M. Alzorizz, Mechanistic approach to the curing of carboxylated nitrile rubber (XNBR) by zinc peroxide/zinc oxide, Polymer, 43 (2002) 1649-1655

[39] L. Ibarra, Ionic elastomers based on carboxylated nitrile rubber (XNBR) and zinc peroxide: Influence of carboxylic group content on properties, J. Appl. Polym. Sci., 84 (2002) 605-615

[40] L. Ibarra, M. Alzorizz, Effect of temperature on crosslink density of NBR and XNBR with zinc peroxide, J. Appl. Polym. Sci., 86 (2002) 335-340

[41] S. Ohno, N. Aburatani, N. Ueda, Foam products from a high-melting synthetic resin, DE szabadalom \# 2914058 (1980)

[42] S. Ohno, N. Aburatani, N. Ueda, Blowing composition, US szabadalom \# 4247412 (1981)

[43] R. Hagel, K. Redecker, Use of zinc peroxide as an oxidizing agent for explosives and pyrotechnical mixtures, DE szabadalom \#2952069 (1981)

[44] M. Farnsworth, C.H. Kline, J.G. Noltes, Zinc. Chem. (1973) 248

[45] F.L. Meleney, Use of Zinc Peroxide in Oral Surgery, Int. J. Orthodontia, 23 (1937) 932

[46] M. Sun, W. Hao, C. Wang, T. Wang, A simple and green approach for preparation of $\mathrm{ZnO}_{2}$ and $\mathrm{ZnO}$ under sunlight irradiation, Chem. Phys. Lett., 443 (2007) 342-346 
[47] Y.C. Zhang, X. Wu, X.Y. Hu, R. Guo, Low-temperature synthesis of nanocrystalline ZnO by thermaldecomposition of a "green" single-source inorganic precursor in air, J. Cryst. Growth, 280 (2005) 250254

[48] L. Rosenthal-Toib, K. Zohar, M. Alagem, Y. Tsur, Synthesis of stabilized nanoparticles of zinc peroxide, Chem. Eng. J., 136 (2008) 425-429

[49] S. Fay, L. Feitknecht, R. Schlüchter, U. Kroll, E. Vallat-Sauvain, A. Shah, Rough ZnO Layers by LP-CVD Process and their Effect in Improving Performances of Amorphous and Microcrystalline Silicon Solar Cells, Sol. En. Mat. \& Solar Cells 90 (2006) 2960-2967

[50] S.M. Smith, H. B. Schlegel, Molecular Orbital Studies of Zinc Oxide Chemical Vapor Deposition: GasPhase Hydrolysis of Diethyl Zinc,Elimination Reactions, and Formation of Dimers and Tetramers, Chem. Mat., 15 (2003) 162-166

[51] B.P. Zhang, N.T. Binh, K. Wakatsuki, Y. Segawa, Y. Yamada, N. Usami, M. Kawaski, H. Koinuma, Pressure-dependent $\mathrm{ZnO}$ nanocrsytal growth in a chemical vapor deposition process, J. Phys. Chem. B., 108 (2004) 10899-10902

[52] Y.F. Gao, M. Nagai, Y. Masuda, F. Sato, K. Koumoto, Electrochemical deposition of ZnO film and its photoluminescence properties, J. Crystal Growth 286 (2006) 445-450

[53] T. Oekermann, T. Yoshida, T. Hada, H. Minoura, Color-sensitive photoconductivity of nanostructured ZnO/dye hybrid films prepared by one-step electrodeposition, Thin Solid films, 511-512 (2006) 354-357

[54] L.Z. Zhang, G.Q. Tang, Preparation, characterization and optical properties of nanostructured ZnO thin films, Optical Materials 27 (2004) 217-220

[55] S. Singh, R.S. Srinivasa, S.S. Talwar, S.S. Major, ZnO and Zn1-xCdxO nanocrystallites obtained by oxidation of precursor Langmuir-Blodgett multilayers, Thin Solid Films 515 (2007) 8714-8717

[56] L Naszályi, A. Deák, E. Hild, A. Ayral, A.L. Kovács, Z. Hórvölgyi, Langmuir-Blodgett films composed of size-quantized $\mathrm{ZnO}$ nanoparticles: Fabrication and optical characterization, Thin Solid Films 515 (2006) 25872595

[57] M. Szekeres, O. Kamalin, R. A. Schoonheydt, K. Wostyn, K. Clays, A. Persoons and Imre Dékány, Ordering and optical properties of monolayers and multilayers of silica spheres deposited by the LangmuirBlodgett method, J. Mater. Chem. 12 (2002) 3268-3277

[58] L. Naszályi Nagy, N. Ábrahám, Ö. Sepsi, E. Hild, D. Cot, A. Ayral, Z. Hórvölgyi, Complex LangmuirBlodgett films of $\mathrm{SiO} 2$ and $\mathrm{ZnO}$ nanoparticles with advantageous optical and photocatalytical properties, Langmuir, 24 (2008) 12575-12580

[59] Z. Li, W. Gao, ZnO zhin films with DC and RF reactive sputtering, Mat. Lett. 25 (2004) 1363-1370

[60] Á. Németh, E. Horváth, Z. Lábadi, L. Fedák, I. Bársony, Single step deposition of different morphology ZnO gas sensing films, Sensors and Actuators B, 127 (2007) 157-160

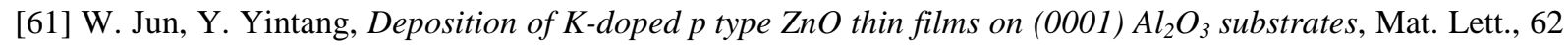
(2008) 1899-1901

[62] X.B. Wang, C. Song, K.W. geng, F. Zeng, F. Pan, Photoluminescence and Raman scattering of Cu-doped ZnO films prepared by magnetron sputtering, Appl. Surf. Sci., 253 (2007) 6905-6909

[63] W. Lan, Y. Liu, M. Zhang, B. Wang, H. Yan, Y. Wang, Structural and optical properties of La-doped ZnO films prepared by magnetron sputtering, Mat. Lett., 61 (2007) 2262-2265

[64] S. Singh, R.S. Srinivasa, S.S. Major, Effect of substrate temperature on the structure and optical properties of ZnO thin films deposited by reactive RF magnetron sputtering, Thin Solid Films, 515 (2007) 8718-8722

[65] J. Hüpkes, B. Rech, O. Kluth, T. Repmann, B. Zwaygardt, J. Müller, R. Drese, M. Wuttig, Surface textured $M F$-sputtered ZnO films for microcrystalline silicon-based thin-film solar cells, Sol. En. Mat.\& Solar Cells, 90 (2006) 3054-3060

[66] S. Mandal, R.K. Singha, A. Dhar, S.K. Ray, Optical and structural characteristics of ZnO thin films grown by rf magnetron sputtering, Mat. Res. Bull. 43 (2008) 244-250

[67] P.F. Yang, H.C. Wen, S.R. Jian, Y.S. Lai, S. Wu, R.S. Chen, Characteristics of ZnO thin films prepared by radio frequency magnetron sputtering, Microelectronics Reliability, 48 (2008) 389-394 
[68] P. Singh, A.K. Chawla, D. Kaur, R. Chandra, Effect of oxygen partial pressure on the structural and optical properties of sputter deposited ZnO nanocrystalline thin films, Mat. Lett., 61 (2007) 2050-2053

[69] N.A. Kotov, I. Dékány. J.H. Fendler, Layer-by-Layer Self-Assembly of Polyelectrolyte-Semiconductor Nanoparticle Composite Films, J. Phys. Chem. 99 (1995) 13065-13069

[70] D. Sebők, K. Szendrei, T. Szabó, I. Dékány, Optical properties of zinc oxide ultrathin hybrid films on silicon wafer prepared by layer-by-layer method, Thin Solid Films 516 (2008) 3009-3014

[71] N.A.Kotov, T.Haraszti, L.Túri ,G.Zavala, R.E.Geer, I.Dékány, J.H.Fendler, Mechanism of and defect formation in the self-assambly of polymeric polycation-montmorillonite ultrathin films, J.Amer.Chem.Soc. 119 (1997) 6821-6832

[72] R. Kun, M. Balázs, I. Dékány, Photooxidation of organic dye molecules in TiO2 and zinc-aluminium double hydroxide ultrathin multilayers, Coll. Surf. A.: Physichochem.Eng. Aspects 265 (2005) 155

[73] G. Decher, J. D. Hong, J. Schmitt, Buildup of ultrathin multilayer films by a self-assembly process: III. Consecutively alternating adsorption of anionic and cationic polyelectrolytes on charged surfaces, Thin Solid Films 210-211 (1992) 831-835.

[74] N.A. Kotov, I. Dékány, J.H. Fendler, Layer-by-Layer Self-Assembly of Polyelectrolyte-Semiconductor Nanoparticle Composite Films, Journal of Phys. Chem. 99 (1995) 13065-13069.

[75] N.A. Kotov, I. Dékány, J.H. Fendler, Ultrathin graphite oxide-polyelectrolyte composites prepared by selfassembly: Transition between conductive and non-conductive states, Advaced Materials 8 (1996) 637-641.

[76] Szabo T, Szeri A, Dekany I, Composite graphitic nanolayers prepared by self-assembly between finely dispersed graphite oxide and cationic polymer, Carbon 43 (2005) 87-94.

[77] T. Szabó, V. Hornok, R.A. Schoonheydt, I. Dékány, Hybrid Langmuir-Blodgett monolyers of Graphite oxide nonosheets, Carbon 48 (2010) 1676-1680

[78] T. Cassier, K. Lowack, G. Decher, Layer-by-layer assembled protein/polymer hybrid films: nanoconstruction via specific recognition, Supramolecular Science 5 (1998) 309-315.

[79] G.B. Sukhorukov, H. Möhwald, G. Decher, Y.M. Lvov, Assembly of polyelectrolyte multilayer films by consecutively alternating adsorption of polynucleotides and polycations, Thin Solid Films 284-285 (1996) 220223.

[80] R. v. Klitzing, H. Möhwald, Transport through ultrathin polyelectrolyte films, Thin Solid Films 284-285 (1996) 352-356

[81] Y. Lvov, K. Ariga, I. Ichinose, T. Kunitake, Molecular film assembly via layer-by-layer adsorption of oppositely charged macromolecules (linear polymer, protein and clay) and concanavalin A and glycogen, Thin Solid Films 284-285 (1996) 797-801.

[82] K. Ariga, Y. Lvov, I. Ichinose, T. Kunitake, Ultrathin films of inorganic materials ( $\mathrm{SiO}_{2}$ nanoparticle, montmorillonite microplate, and molybdenum oxide) prepared by alternate layer-by-layer assembly with organic polyions, Applied Clay Science 15 (1999) 137-152.

[83] M. Szekeres, A Széchenyi, K. Stépán, T. Haraszti and I. Dékány, Layer-by-layer self assembly preparation of layered double hydroxide/polyelectrolyte sandwiched nanofilms by surface plasmon resonance spectroscopy, Coll. and Poly. Sci., 283 (2005) 937-945

[84] V. Hornok, A. Erdőhelyi and I. Dékány, Preparation of ultrathin membranes by layer-by-layer deposition of layered double hydroxide (LDH) and polystyrene sulfonate (PSS), Coll. and Poly. Sci. 283 (2005) 1050-1055

[85] V. Hornok, A. Erdőhelyi and I. Dékány, Preparation of ultrathin membranes by layer-by-layer (LBL) deposition of oppositly charged inorganic colloids, Coll. and Poly. Sci. 284 (2006) 611-619

[86] T. Aradi, V. Hornok, I. Dékány, Layered double hydroxides for ultrathin hybrid film preparation using layer-by-layer and spin coating methods, Colloids and Surfaces A: Physicochemical and Engineering Aspects 319 (2008) 116-121.

[87] K. Glinel, Ch. Déjugnat, M. Prevot, B. Schöler, M. Schönhoff, R. v. Klitzing, Responsive polyelectrolyte multilayers, Colloids and Surfaces A: Physicochemical and Engineering Aspects 303 (2007) 3-13.

[88] S. Schmidt, H. Motschmann, T. Hellweg, R. v. Klitzing, Thermoresponsive Surfaces by Spin-Coating of PNIPAM-co-PAA Microgels. A Combined AFM and Ellipsometry study, Polymer 49 (2008) 749-756 
[89] M. Schönhoff, V. Ball, A. R. Bausch, Ch. Dejugnat, N. Delorme, K. Glinel, R. v. Klitzing, R. Steitz, Hydration and internal properties of polyelectrolyte multilayers, Coll. Surf. A: Phys. and Eng. Asp 303 (2007) 14-29

[90] G. Sukhorukov, A. Fery, H. Möhwald, Intelligent micro- and nanocapsules, Progress in Polymer Science 30 (2005) 885-897.

[91] M. Rusu, D. Kuckling, H. Möhwald, M. Schönhoff, Adsorption of novel thermosensitive graft-copolymers: Core-shell particles prepared by polyelectrolyte multilayer self-assembly, Journal of Colloid and Interface Science 298 (2006) 124-131.

[92] W. Song, Q. He, H. Möhwald, J. Li, Smart Polyelectrolyte Microcapsules as Carriers for Water-soluble Small Molecular Drug, J. of Contr. Release 139 (2009) 160-166

[93] R. Swanepoel, Determination of the thickness and optical constants of amorphous silicon, J. Phys. E: Sci.Instrum. 19 (1984) 1214

[94] F. Tepehan, N. Özer, A simple method for the determination of the optical constants, nand $\mathrm{k}$ of cadmium sulfide films from transmittance measurements, Solar Energy Materials and Solar Cells 30 (1993) 353-365

[95] J. Sánchez-González, A. Díaz-Parralejo, A.L. Ortiz, F. Guiberteau, Determination of optical properties in nanostructured thin films using the Swanepoel method, Applied Surface Science 252 (2006) 6013-6017

[96] G. Yu, G. Wang, H. Ishikawa, M. Umeno, T. Soga, T. Egawa, J. Watanabe, and T. Jimbo, Optical properties of wurtzite structure GaN on sapphire around fundamental absorption edge $(0.78-4.77 \mathrm{eV})$ by spectroscopic ellipsometry and the optical transmission method, Appl. Phys. Lett. 70 (1997) 3209-3211

[97] I. Ay and H. Tolunay, Optical Transmission Measurements on Glow-Discharge Amorphous Silicon Nitride Films, Turk J Phy 25 (2001) 215- 222

[98] R. M. A. Azzam and N. M. Bashara, Ellipsometry and Polarized Light, Elsevier Science Pub Co (1987) ISBN 0-444-87016-4

[99] F. K. Shan, Z. F. Liu, G. X. Liu, B. C. Shin and Y. S. Yuz, S. Y. Kim, T. S. Kim, Spectroscopic Ellipsometry Characterization of Al-Doped ZnO Thin Films Deposited by Pulsed Laser Deposition, J. Kor. Phys. Soc. 44 (2004) 1215-1219

[100] L. A. A. Pettersson, L. S. Roman, and O. Inganäs, Modeling photocurrent action spectra of photovoltaic devices based on organic thin films, J. Appl. Phys. 86 (1999) 487

[101] H. Arwin, Spectroscopic ellipsometry and biology: recent developments and challenges, Thin Solid Films 313-314 (1998) 764-774

[102] Hans Arwin, Ellipsometry on thin organic layers of biological interest: characterization and applications, Thin Solid Films 377-378 (2000) 48-56

[103] B. Schulz, D. Chan, J. Bäckström, M. Rübhausen, Spectroscopic ellipsometry on biological materials investigation of hydration dynamics and structural properties, Thin Solid Films 455-456 (2004) 731-734

[104] J. C. Maxwell-Garnett, On a Generalised Theory of Alternative Inheritance, with Special Reference to Mendel's Laws, Philos. Trans. R. Soc. Lond. 203 (1904) 385

[105] M. Y. Koledintseva, R. E. DuBroff, and R. W. Schwartz, A Maxwell Garnett model for dielectric mixtures containing conductive particles at optical frequencies, Progress In Electromagnetics Research 63 (2006) 223242

[106] D. A. G. Bruggeman, Berechnung verschiedener physikalischer Konstanten von heterogenen Substanzen, Ann. Phys. (Leipz.) 24 (1935) 636

[107] Weiglhofer, W. S.; Lakhtakia, A.; Michel, B., Maxwell Garnett and Bruggeman formalisms for a particulate composite with bianisotropic host medium, Microw. Opt. Technol. Lett. 15 (1998) 263-266.

[108] F. Bordi, C. Cametti, T. Gili, Dielectric spectroscopy of erythrocyte cell suspensions. A comparison between Looyenga and Maxwell-Wagner-Hanai effective medium theory formulations, Journal of NonCrystalline Solids 305 (2002) 278-284

[109] W. Theiß, Optical properties of porous silicon, Surf. Sci. Rep. 29 (1997) 91-192 
[110] M. Brust, M. Walker, D. Bethell, D. J. Schriffin and R. Whyman, Synthesis of Thiol-derivatised Gold Nanoparticles in a Two-phase Liquid-Liquid System, J. Chem. Soc., Chem. Commun., (1994) 801-802

[111] 76-1364 JCPDS kártya

[112] 36-1451 JCPDS kártya

[113] Dr. Ábrahám György: Optika, Panem-McGraw-Hill, 1998

[114] L. Janovák, J. Varga, L. Kemény, I. Dékány, Investigation of the structure and swelling of poly( $N$ isopropyl-acrylamide-acrylamide) and poly(N-isopropyl-acrylamide-acrylic acid) based copolymer and composite hydrogels, Colloid and Polymer Science 286 (2008) 1575-1585

[115] N. Molnár Vörös, R. Patakfalvi, I. Dékány, Alkylthiol-functionalized gold nanoparticles for sensing organic vapours: The connection between the adsorption isotherm and the sensor resistance, Coll. Surf. A: Physicochemical and Engineering Aspects, 329 (2008) 205-210

[116] Tyukodi B., Párolgás pohárból, Szakkollégiumi kutatási beszámoló 2008-2009, Babeş-Bolyai Tudományegyetem

[117] S. J. Blundell, K. M. Blundell: Concepts in Thermal Physics, Oxford, University Press, 2006 